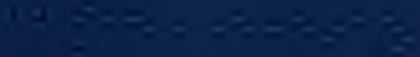

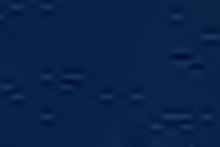

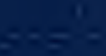






\section{A SYNOPSIS OF THE \\ FAMILIES AND GENERA OF NEMATODA}





\section{A SYNOPSIS OF THE}

\section{FAMILIES AND GENERA OF NEMATODA}

BY

H. A. BAYLIS, M.A., D.Sc.

BRTISI MUSEUM (NATURAL HISTORT)

AND

R. DAUBNEY, M.Sc., M.R.C.V.S.

VETERIVARY RESEARCI LABORATORY, EABETE, KENYA COLONY

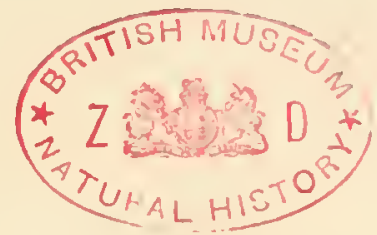

LONDON :

PRINTED BY ORDER OF THE TRUSTEES OF THE BRITISH MUSEUMI

SOLD AT

THE BRITISH MUSEUM (NATURAL HISTORY), OROMWELL ROAD, S.W. 7 ASD BX

B. QUARITCH, LTD. ; DULAU \& CO., LTD.; THE OKFORD UNITERSTTY

PRESS; AND WHELDON \& WESLEY, LTD., LONDON; ALSO BY

OLIVER \& BOTD, EDINBURGH

1926

(All rights reserved)

Jssued 27 March, 1926] 
Printed in Great Britain by lillhard Clay \& Sons, Limited, BUNGAY, SUFFOLK. 


\section{PREFACE}

'THE vast literature of the Nematoda is extremely scattered and is contained in periodicals dealing with very varied subjects. Owing to the economic importance of the group there are many students of it; these must have felt the need of a comprehensive work on the Nematoda, and the present volume is the result of an attempt by Dr. Baylis and Captain Daubney to remedy this deficieney. The Synopsis is not merely a compilation, for the authors have made some im. portant proposals in regard to classification, and have themselves examined material representing a large proportion of the parasitic genera.

The authors wish to thank Mr. B. P. Uvarov, whose kind assistanee has enabled them to give diagnoses of a number of genera deseribed in the Russian language. The authors also wish to thank those helminthologists who have sent separate copies of their papers; these have greatly facilitated the preparation of this volume.

British Museum (Natural History),

C. Tate Regan,

Keeper of Zoology. March, 1926. 



\section{INTRODUCTION}

No monograph exists embracing the Nematoda as a whole, and eontaining diagnoses either of genera, of families or of higher groups, to which a worker who is not a speeialist ean turn for assistance in the determination of specimens. It is ehiefly with the object of relieving this situation to some slight extent that the present work has been undertaken. In the labour of compiling it we have been very greatly assisted by Stiles and Hassall's valuable Index-Catalogue of Medieal and Veterinary Zoology. Indeed, it is only the recent publication (1920) of the subjeet-volume dealing with Roundworms that has made it possible to gather together a collection of generic diagnoses in any degree approaching eompleteness. Incidentally, the attempt to colleet these diagnoses has demonstrated that a large proportion of those to be found in the literature are totally inadequate, and in many instanees it is doubtful whether the genera concerned ean ever again be recognized. This statement, so far as the more modern literature is concerned, refers particularly to the free-living forms.

When the present work had already been in preparation for some months, it came to our knowledge that Professor Warrington Yorke and Dr. P. A. Maplestone, of the Liverpool School of Tropical Medicine, were preparing a book on somewhat similar lines, ${ }^{*}$ and that it was in a considerably more advaneed state than our own. We learnt, however, that it was the authors' intention to deal only with the Nematodes parasitic in Vertebrates. Professor Yorke, with the greatest kindness and generosity, sent us the proofs of the book before its publication, and allowed us to make use of them in eompleting our work. It was, however, unfortunately too late for us to make full references to the book throughout the text, and we have only done so where we have been particularly indebted to it for fresh information.

Our original plan was to confine our attention to genera published before the end of the year 1923, and we have adhered fairly strietly to this prineiple. It was found impossible to obtain and consult all the literature necessary to keep pace with the eonstant output of new genera since that date, and so render the eatalogue complete up to the moment of publiea-

* The Nematode Parcusites of Vertebrates, London (1926). 
tion. Accordingly, although we have frequently made reference to literature published since 1923, where it has been important for our purpose, we have not included the new genera proposed, unless they appeared to be synonyms of earlicr gencra, or were merely new names proposed to replace older ones which were preoccupicd.

We consider that the prevailing custom of separating the Nematodes into free-living and parasitic groups leads to an entirely umnatural scheme of classification. All degrces of parasitism, permanent and temporary, are found among the Nematodes, and any such arbitrary division must be made in total disregard of obvious morphological similarities. All the Ncmatodes resemble each other, in general appearance and structure, far more closely than do, for example, Insects of different orders. Yet within a given order of Insects it is well known that there may be both free-living and parasitic forms, and a preliminary division of the Insects as a whole into free-living and parasitic groups would not be regarded seriously by any modern entomologist. In the Nematodes the custom referred to was doubtless adopted by specialists for their own convenience, since it was almost impossible for one worker to be conversant with the literature of the whole group.

The evidence a vailable points, in our view, to the derivation of all parasitic Nematodes from free-living ancestors, and there are indications that the habit of parasitism has been developed not once only, but at various times in the evolutionary history of the group. It is accordingly impossible to point to any one group of free-living forms as the origin of all the parasitic forms. Certain parasitic forms, not closely related to each other, still retain evident traces of primitive structure, and their affinities to free-living gencra are clear. For cxample, a close connection appears to exist between the semi-parasitic Nermithidae and the Anguillulinidae, and between the parasitic Oxyuridae and Atractidae and the mainly free-living Rhabditidac.

We have, therefore, attempted to unite the whole of the Nematoda in a common system of classification. It is not suggested that the proposed system is in any way perfect or permanent. It may, however, point the way to a more natural classification in the future, especially if our knowledge of the imperfectly-diagnosed forms becomes more complete. It seems to us convemient, and not in any way unscientific or illogical, to regard the Nematoda as a self-contained Class of the animal kingdom. We do not feel called upon, in a work of this character, to enter into a discussion of the relationships of this Class to other groups. The Nematoda have been gencrally treated as forming part of a Phylum Nemathelminthes, which is taken to include also the Nematomorpha or 
Gordiacea, the Acanthocephala, and possibly some other small groups of very uncertain affinities. Without entering into the vexed question of the "naturalness " of this arrangement, we propose here to deal only with the Nematoda proper, to the exclusion of all the other groups.

The primary divisions of the Class Nematoda are treated as Orders, corresponding broadly to some of the "Superfamilies " originated by Railliet and others, and now accepted by the majority of helminthologists. The classification we have adopted starts with the assumption, which seems to us to be well-founded, that the forms with three lips, or obvious modifications of three lips, are to be regarded as primitive. The majority of these have been grouped together in one large Order, Ascaroidea.*

The other Orders are regarded as collateral branches that have originated independently of each other from the original stock now represented by the Ascaroidea. Thus the Strongy loidea still retain evidences of the three-lipped arrangement, although they have become considerably modified in other directions; they have a true bursa in the male, and a definite system of bursal rays which is not paralleled among the Ascaroidea. There is a striking resemblance between the free-living larval stages of Strongyloidea generally, and particularly of the forms with a buccal capsule, and the adults of many of the free-living terricolous forms here included in the Ascaroidea. A similar resemblance exists between the larvæ of the Mermithidae and the adults of the Anguillulinidae.

The Filarioidea have departed much more widely from the primitive type, having lost all traces of the triradial symmetry of the lips, except in retaining the nsual number (six) of cephalic papillæ. This divergence may possibly be connected with the introduction of a complex life-cycle involving an intermediate host. The two remaining Orders (Dioctophymoidea and Triclinelloidea) are small, very highly-specialized groups whose relationships cannot easily be determined.

A survey of the whole of the Nematoda shows that there has been too great a tendency on the part of workers with comparatively restricted interests to raise the rank of the small groups with which they were dealing. For instance, Cobb, in a recent publication, divides the free-living Nematodes alone into two subphyla with classes, subclasses and orders. One of his subphyla, the Alaimia, corresponds to the family

* The use of the name Ascaroidea for this group should not be taken to imply that the Ascaridae are regarded as its most primitive members. These are undoubtedly to be found among the free-living genera, and the Ascaridae, apart from the primitive arrangement of the lips, are very highly specialized in accordance with their strictly parasitic mode of life. 
Alaimidae of other workers. The bursate parasitic Nematodes, similarly, have, in the course of a few years, risen from the rank of a family, Strongylidae, to that of a suborder, Strongylata. We have been compelled to reduce the rank of many groups, owing to the false position which the Nematoda must assume in relation to the animal kingdom as a whole if this practice of elevating small groups were continued. Further, the subdivision of groups tends to keep paee with their elevation in rank, and it becomes impossible to find characters of sufficient weight to justify the subdivisions made. Individual instances of this diffienlty will be remarked upon in the appropriate places in the text.

The generie diagnoses given are not simply extraets from those given by the original authors. We have endeavoured to make use of any subsequent literature whieh has modified the original diagnosis, and have often taken eharacters direetly from the genotype. We have also tried to define groups in terms whieh are mutually exelusive, wherever this is possible. It will be seen that the better-known groups usually need only short diagnoses to separate them from each other, whereas the separation of less well-known forms frequently necessitates the use of much longer deseriptions, embraeing eharacters of less importanee, and, it is to be feared, often of doubtful reliability.

The quotation of an author's name in conjumetion with the name of a subfamily or higher group implies no more than that that anthor was the originator of the name.

\section{References to Literature}

At the end of eaeh diagnosis the genotype is speeified, and references are given to the more important sourees of our information regarding the genus and its genotype. No attempt is made to give a complete bibliography. The abbreviations used to indicate the titles of publications are, in general, those employed in the Zoological Record.

\section{Synonyms}

In giving the synonymy of generie names we have endeavoured to include all total synonyms, but have not considered it neeessary or desirable to mention all the partial synonyms or obvious misspellings. For example, the family Ascaridae, as here understood, is roughly eo-extensive with the genus Ascaris in its original, wide sense, and if all partial synonyms were to be given, it would have been necessary to include Ascaris in the synonymy of almost every genus in the family. It is doubtful whether this would have served any useful purpose. We have, however, given in square brackets 
the generic name originally given to the genotype of each genus, wherever this has subsequently been changed.

\section{Definitions}

In descriptions of Nematodes, the same term is not infrequently used by different authors to denote quite different structures; it is therefore necessary to define the more important descriptive terms used in this work.

Accessory piece.-A more or less strongly-chitinized structure (frequently serving as a guide for the copulatory spicules), developed in connection with the dorsal wall of the cloaca of the male. (By many authors this structure is called the gubernaculum).

Buccal capsule.-A cavity into which the mouth leads and which opens bchind into the oesophagus, and having a chitinoid wall which is not surrounded externally by muscular tissue. In some families the dnct of a dorsal oesophageal gland is visible in the wall of the capsule, and is referred to as the dorsal gutter.

Buccal cavity.-This term is sometimes used where it is difficult to determine whether the structure referred to is a buccal capsule or a pharynx.

Buccal valves.-The shell-shaped, chitinoid, lateral halves of the buccal capsule wall, when it is not a continuous structure.

Bursa.-A cuticular expansion of the caudal end of the male in the Strongyloidea, supported by a definite system of "rays." (Cuticular expansions of the caudal end not supported by this definite system of rays are referred to as caudal alae). bursa :-

The following nomenclature is adopted for the rays of the

$$
\begin{gathered}
\text { Ventral rays }\left\{\begin{array}{l}
\text { ventro-ventral, } \\
\text { latero-ventral. }
\end{array}\right. \\
\text { Lateral rays }\left\{\begin{array}{l}
\text { antero-lateral, } \\
\text { medio-lateral, } \\
\text { postero-lateral. }
\end{array}\right.
\end{gathered}
$$

Externo-dorsal rays.

$$
\text { Dorsal ray. }
$$

Caudal glands.--Unicellular glands in the caudal region, commonly present in free-living forms, and producing a cement-like secretion which may serve for fixation to solid objects. For the specialized terminal portion of the common duct of these glands Cobb's term spinneret is employed. (This corresponds to the "caudal sucker" of Bastian).

Cordons.-Grooves, tubular channels or festoon-like ornaments in or on the cuticle of the cervical region.

Dentigerous ridges.-Rows of denticles situated on the inner surface of the lips. 
Genital cone.-A terminal or subterminal, postanal, ventral process in male Strongyloidea, which may have on its ventral surface a granular and thickened cutiele, referred to by some authors as a dermal collar.

Head.-Although there is no real head in Nematodes, the anterior portion of the animal, earrying the mouth, lips and cephalie papillae or other specialized sensory organs, is frequently referred to as the "head." When this region is marked off from the portion of the body following it by a constriction, or by being itself of greater diameter, it is deseribed as distinct.

Lateral organs.--Paired lateral subeutienlar organs near the anterior end of the body, presumably sensory in function, occurring in many free-living forms and apparently homologons with the lateral cephalie papillae of more highlyspecialized parasitic forms. (The "amphids" of Cobb).

Lips.-Clearly-difierentiated struetures surrounding the mouth and bearing sensory papillae on their external surfaces.

Mouth-collar.-A ring-like cuticular swelling sometimes surrounding the anterior extremity, immediately behind the mouth-opening, in the Strongyloidea.

Ocelli.-Masses of pigment within the body-cavity, usually closely eonneeted with the oesophagus, and sometimes provided with hyaline lenses. (Referred to by some authors as eyes or eye-spots).

Oesophageal funnel.-A funnel-shaped expansion of the lumen of the oesophagus at its anterior end, immediately behind its junction with the buecal eapsule or pharynx. The fumnel is frequently lined with thiekened cutiele.

Ovejectors.- Specialized muscular portions of the female genital tubes, near their junction with the vagina, serving to control the deposition of ova.

Oviparous.-Producing eggs which hatch some time after deposition.

Ovoviviparous.-Produeing eggs which may or may not have shells, and which hatch immediately after deposition.

Pharynx.- Resembles a buccal capsule, but has an external muscular coat.

Sucker.-A depression supplied with muscles and with a thickened cuticular border. In the absenee of a thickened cutieular border, such structures are usually referred to as sucker-like organs.

Supplementary organs.-Modified preanal or postanal papillac on the ventral surface of the male in many free-living genera, having frequently a more or less eomplex ehitinoid framework. (The "sucker-tubes" of Bastian, and the "Haftorgane" of some German authors). 
Tail.-The portion of the body between the anus or cloacal opening and the posterior extremity.

Teeth.-This term is reserved for comparatively simple structures on the lips or within the mouth, buccal capsule pharynx or oesophagus. Complex serrate or denticulate structures (e.g., such as occur in Crossocephalus) are termed jaws.

Telamon-A more or less strongly-chitinized supporting structure, of varying shape, developed in connection with the ventral wall of the cloaca of the male.

Viviparous.-Producing eggs which hatch while still contained in the uterus. 



\section{SYSTEMATIC INDEX}

\section{NEMATODA}

\section{Order I. ASCAROIDEA}

Fam. 1. ASCARIDAE

Subfam.1. Ascarinae page

1. Ascaris Limnaens . . . . . . . 1

2. Ophidascaris Baylis. . . . . . . 1

3. Polydelphis Dujardin . . . . . . 2

4. Toxocara Stiles . . . . . . . 2

5. Toxascaris Leiper . . . . . . . 3

6. Lagochilascaris Leiper . $\quad$. $\quad$. $\quad$. 3

7. Orneoascaris Skrjabin . . . . . 4

8. Trispiculascaris Skrjabin . . . . . 4

Subfam 2. ANISAKINAE

1. Anisakis Dujardin . . . . . 5

2. Raphidascaris Railliet \& Henry . . . . 5

3. Porrocaecum Railliet \& Henry . . . . 6

4. Contracaecum Railliet \& Henry . . . . 6

5. Cloeoascaris Baylis . . . . . . . 6

6. Galeiceps Railliet . . . . . . 6

7. Paranisakis Baylis . . . . . . 7

8. Dujardinia Gedoelst . . . . . . 7

9. Multicaecum Baylis . . . . . . . 7

10. Angusticaecum Baylis. . . . . . 8

11. Amplicaecum Baylis . . . . . . 8

12. Crossophorus Ehrenberg . . . . . 8

13. Goezia Zeder . . . . . . . 9

14. Acanthocheilus Molin . . . . . . 9

15. Lobocephalus Diesing . . . . . 10

16. Typhlophoros v. Linstow . . . . 10

17. Heligmus Dujardin . • . . . 10 
Fam. 2. HETERAKIDAE

Subfam. 1. Heterakinae

1. Heterakis Dujardin

2. Pseudaspidodera Baylis \& Daubney . . . 11

3. Ascaridia Dujardin . . . . . . 12

4. Aspidodera Railliet \& Henry . . . . 12

5. Paraspidodera Travassos . . . . . . 12

6. Strongyluris Müller . . . . . . . 13

7. Spinicauda Travassos . . . . . 13

S. Africana Travassos . . . . . . 14

Subfam. 2. Subuturinae

1. Subulura Molin . . . . . . . 14

2. Oxynema v. Linstow . . . . . . 14

3. Heteroxynema Hall . . . . . . . 15

4. Numidica Barreto . . . . . . 15

5. Maupasina Seurat . . . . . . 15

Fam. 3. KATHLANIIDAE

1. Kathlania Lane . . . . . . 16

2. Tonaudia Travassos . . . . . . 17

3. Spironoura Leidy . . . . . . 17

4. Zanclophorus Baylis \& Daubuey . . . . 18

5. Cruzia Travassos . . . . . . 18

6. Cissophyllus Railliet \& Henry . . . . . 19

7. Probstmayria Ransom . . . . . 19

8. Amblyonema v. Linstow . . . . . 20

9. Spectatus Travassos . . . . . 20

Fam. 4. OXYASCARIDAE

1. Oxyascaris Travassos . . . . . . 20

Fam. 5. OXYURIDAE

Subfam. 1. Oxyurinae

1. Oxyuris Rudolphi . . . . . . 21

2. Dermatoxys Schneider . . . . . 22

3. Hoplodontophorus Turner . . . . . 22

4. Enterobius Leach . . . . . . 23 
5. Protozoophaga Travassos

6. Thelandros Wedl

7. Ozolaimus Dujardin .

8. Macracis Gedoelst

9. Pharyngodon Diesing .

10. Tachygonetria Wedl .

11. Aorurus Leidy .

12. Thelastoma Leidy

13. Pseudonymus Diesing

14. Passalurus Dujardin

15. Wellcomia Sambon . . . . . . 28

16. Syphacia Seurat . . . . . . 29

17. Haplacis Railliet \& Henry . . . . 29

Subfam. 2. Cosmocercinae

1. Cosmocerca Diesing

2. A plectana Railliet \& Henry

3. Oxysomatium Railliet \& Henry . . . . 31

4. Syphaciella Monnig . . . . . . . 31

5. Carnoya Gilson . . . . . . . 31

6. Isakis Lespès . . . . . . . . 32

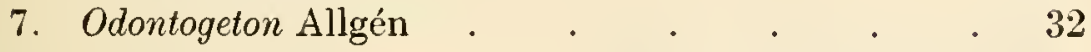

Fam. 6. ATRACTIDAE

1. Atractis Dujardin

2. Labiduris Schneider

3. Crossocephalus Railliet

4. Rondonia Travassos

5. Cobboldina Leiper

6. Cyrtosomum Gedoelst

7. Monhysterides Baylis \& Daubney . . . 35

8. Leiperenia Khalil 
4. Anguillula Ehrenberg

5. Diploscapter Cohb .

6. Cephalobus Bastian

6a. Subgenus Acrobeles v. Linstow

7. Macrolaimus Maupas

8. Diplogaster M. Sehultze

9. Demaniella Steiner

10. Chambersiella Cobb

11. Teratocephalus de Man

12. Rhabdolaimus de Man

13. Protrellus Cobb.

14. Blatiophila Cobb

15. Cephalobium Cobb

16. Lepidonema Cobb

17. Hystrignathus Leidy . 45

18. Heth Cobb

Appendix to Rhabditinae

19. Allantonema Leuckart

20. Sphaerularia Dufour

Subfam. 2. Cylindrolaiminae

1. Cylindrolaimus de Man

2. Siphonolaimus de Man

3. Chromagasier Cobb

4. Camacolaimus de Man

5. Dermatolaimus Steiner

6. Gymnolaimus Cobb .

7. Leptolaimus de Man .

8. Aulolaimus de Man .

9. Isolaimium Cobb

10. Cryptonchus Cobb

11. Ceramonema Cobb

12. Colpurella Cobb

13. Cynura Cobb

14. Xinema Cobb

15. Halinema Cobb

16. Crystallonema Cobb 
17. Halanonchus Cobb

18. Illium Cobb

19. Laimella Cobb .

20. Omicronema Cobb

54

21. Pseudolella Cobb

22. Rhadinema Cobb

23. Rhynchonema Cobb

24. Myctolaimus Cobb

55

25. Plectus Bastian .

56

25a. Subgenus Wilsonema Cobb . . . . . $\quad$. 56

26. Aplectus Cobb . . . . . . . 56

27. Haliplectus Cobb . . . . . . 57

28. Aulolaimoides Micoletzky . . . . . 57

29. Bolbonema Cobb

Subfam. 3. Bunoneminae

1. Bunonema Jägerskiöld . . . . . 58

2. Craspedonema Richters . . . . . 58

Appendix to Rhabditidae

a. Zalonema Cobb .

b. Monhystrium Cobb . . $\quad$. $\quad$. 50.59

c. Tripylium Cobb . . . . . $\quad$. 59

d. Leptodera Dujardin . . . . . . 60

e. Streptogaster Cobb . . . . . . 60

f. Walcherenia de Man . . . . . . 60

g. Terschellingia de Man . . . . . . 61

gg. Subgenus Oligomonohystera Micoletzky • • 61

h. Chronogaster Cobb. . . . . . . 61

i. Dasynema Cobb $\quad . \quad$. $\quad$. $\quad$. $\quad$. $\quad 62$

j. Halaphanolaimus Southern .., . 62

k. Antomicron Cobb . . . . . . 62

l. Laxonema Cobb . . . . . . . 63

m. Pararhabditis nom. nov. . . . . . 63

Fam. 8. MERMITHIDAE

1. Mermis Dujardin 


\section{Fam.9. ANGUILLULINIDAE}

Subfam. 1. Anguillulininae

1. Anguillutina Gervais \& van Beneden . . . 65

2. Tylenchulus Cobb . . . . . . . 66

3. Aphelenchus Bastian . . . . . 67

4. Heterodera Schmidt . . . . . . 67

5. Nemonchus Cobb . . . . . . . 68

6. Hoplolaimus Daday . . . . . . 69

7. Psilenchus de Man . . . . . . . 69

8. Isonchus Cobb . . . . . . . . $\quad$. 69

9. Tylopharymx de Man . . . . . . 70

Subfam. 2. Dorylaiminae

1. Dorylaimus Dujardin . . . . . . 70

2. Trichodorus Cobb . . . . . . . 71

3. Campydora Cobb . . . . . . 71

4. Onchium Cobb. . . . . . . 72

5. Onchulella Cobb . . . . . . . 72

6. Triplonchium Cobb . . . . . . 72

7. Diphtherophore de Man . . . . . 73

8. Tylencholaimus de Man . . . . . 73

9. Brachynema Cobb . . . . . . 74

10. Tylencholaimellus M. V. Cobb . . . . 74

11. Tylolaimophorus de Man . . . . . 74

12. Ecphyadophora de Man . . . . . 75

Appendix to Anguillulinidae

a. Nyenchus Schuberg \& Schröder . . . . 75

b. Myoryctes Ebcrth . . . . . . 75

Fam. 10. TRILOBIDAE

1. Trilobus Bastian . . . . . . 76

2. Paratrilobus Micoletzky . . . . $\quad$. 77

3. Choanolaimus de Man . . . . . 77

4. Anoplostoma Bütschli . . . . . 77

5. Sphaerolaimus Bastian . . . . . 77

6. Didelta Cobb . . . . . . . 78

7. Desmolaimus de Man. . . . . . 78 
8. Myolaimus Cobb . . . . . . 78

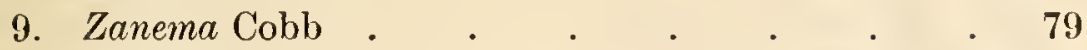

10. Paraphanolaimus Micoletzky . . . . 79

11. Pseudonchus Cobb . . . . . . 79

12. Monhystera Bastian . . . . . . 80

13. Daptonema Cobb . . . . . . 80

14. Dintheria de Man . . . . . . 81

15. Monohystrella Cobb . . . . . . . 81

16. Cephalobellus Cobb . . . . . . . 81

17. Trefusia de Man . . . . . . $\quad . \quad$. 82

18. Tripyloides de Man . . . . . . . 82

19. Bathylaimus Cobb . . . . . . $\quad$. 82

20. Axonolaimus de Man . . . . . . 83

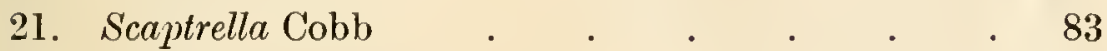

22. Polylaimium Cobb . $\quad$. $\quad$. $\quad$. $\quad$. 83

23. Ascolaimus Ditlevsen . . . . . 84

24. Stephanolaimus Ditlevsen . . . . . 84

25. Dactylaimus Cobb . . . . . 84

26. Krampia Ditlevsen . . $\quad$. $\quad$. $\quad$. $\quad 85$

27. Leptogastrella Cobb . . . . . . 85

28. Margonema Cobb . . . . . . $\quad$. 85

29. Xenolaimus Cobb . . . . . . . 85

30. Necticonema Marion . . . . . . $\quad 86$

31. Coinonema Cobb . . . . . 86

32. Prismatolaimus de Man . . . . . . 86

33. Anonchus Cobb . . . . . . 87

34. Araeolaimus de Man . . $\quad$. $\quad$. $\quad$. 87

34a. Subgenus Araeolaimoides de Man . . $\quad$. 87

35. Fimbrilla Cobb . . . . . . . . 88

36. Anticyathus Cobb . . . . . . . 88

37. Sphaerocephalum Filipjev . "

Appendix to Trilobidae

a. Acmaeolaimus Filipjev . . . . $\quad$. 89

b. Symplocostoma Bastian . . . . . $\quad$. 89

c. Pelagonema Cobb . $\quad$. $\quad$. $\quad$. $\quad$. $\quad$. 89

d. Diplohystera Onorato-de Cillis . $\quad$. $\quad$. 89 
e. Seuratiella Ditlevsen .

f. Cricolaimus Southern

g. Platycoma Cobb

h. Solenolaimus Cobb

i. Eleutherolaimus Filipjev

j. Trilepta Cobb .

Fam. 11. ALAIMIDAE

1. Alaimus de Man

2. Alaimella Cobb .

3. Anticoma Bastian

4. Enchelidium Ehrenberg

5. Aegialolaimus de Man

6. Aphanoluimus de Man

7. Halalaimus de Man

8. Iotalaimus Cobb

9. Bastiania de Man

10. Deontolaimus de Man

11. Thalassoalaimus de Man

12. Bolbinium Cobb

13. Cyartonema Cobb

14. Tripyla Bastian

15. Nuada Southern

16. Leptosomatum Bastian

17. Acoma Steiner .

18. Oxystomina nom. nov.

19. Litonema Cobb

20. Hyalaimus Cobb

21. Macroposthonia de Man

22. Campylaimus Cobb

23. Helalaimus Onorato-de Cillis

24. Hemicycliophora de Man

25. Ionema Cobb

26. Leptonemella Cobb

27. Litinium Cobb .

28. Litotes Colsb

29. Molgolaimus Ditlevsen 
30. Porocoma Cobb .

31. Nemella Cobb .

32. Schistodera Cobb

33. Stilbonema Cobb

34. Stenolaimus Marion

35. Tycnodora Cobb

102

36. Xennella Cobb .

102

37. Neurella Cobb .

102

38. Nannolaimus Cobb

102

39. Cytolaimium Cobb

103

40. Diplopeltis Cobb

41. Zygonemella Cobb

42. Spirina Filipjev

43. Nemanema Cobb

44. Disconema Filipjev

103

45. Prosphaerolaimus Filipjev

103

104

104

104

105

105

Appendix to Alaimidae

a. Linhomoella Cobb

b. Mastodex Steiner

Fam. 12. CHAETOSOMATIDAE

1. Chaetosoma Claparède

106

2. Draconema Cobb . . . . . . 106

3. Prochaetosoma nom. nov. . : . . . 107

4. Notochaetosoma Irwin-Smith . . . . 107

\section{Fam. 13. DESMOSCOLECIDAE}

1. Desmoscolex Claparède

2. Tricoma Cobb

3. Eudesmoscolex Steiner

108

4. Greeffiella Cobb .

5. Richtersia Steiner

Fam. 14. ONCHOLAIMTDAE

\section{Subfam 1. ONCHOLATMINAE}

1. Oncholaimus Dujardin

2. Paroncholaimus Filipjev . . . . . 111

3. Oncholaimellus de Man . . . . . . 111 
4. Mononchulus Cobb

5. Rhabdodemania nom. nov. .

6. Gammanema Cobb

7. Spilophora Bastian

8. Cobbionema Filipjev .

113

9. Bolbella Cobb .

114

10. Polygastrophora de Man

114

11. Eurystomina Filipjev .

114

12. Phanoderma Bastian .

115

13. Anaxonchium Cobb

115

14. Thoönchus Cobb

116

15. Mononchus Bastian

116

15a. Subgenus Mononchus

117

15b. , Prionchulus Cobb

15c. , Anatonchus Cobb

15d. , Iotonchus Cobb.

15e. " Mylonchulus Cobb

15f. , , Sporonchulus Cobb

16. Oionchus Cobb .

17. Udonchus Cobb

18. Odontopharynx de Man

19. Alaimonema Cobb .

20. Aponchium Cobb

21. Catanema Cobb

22. Pseudobathylaimus Filipjev . . . 120

23. Croconema Cobb . . . . . . . 120

24. Cylicolaimus de Man . . . . . . . 121

25. Synonchus Cobb . . . . . . . 121

26. Microlaimus de Man . . . . . . $\quad$. 122

27. Odontobius Roussel de Vauzème . . . . 122

28. Chromaspira Filipjev . . . . . . . 122

29. Rhips Cobb . . . . . . . . 123

30. Linhomoeus Bastian . . . . . . 123

31. Metalinhomoeus de Man . . . . . 124

32. Cothonolaimus Ditlevsen . . . . . 124

33. Comesoma Bastian . . . . . . 124

34. Dagda Southern . . . . . . 125 
35. Cyatholaimus Bastian

36. Chromadora Bastian .

37. Parachromadora Micoletzky

38. Bolbolaimus Cobb

39. Cobbia de Man .

Subfam 2. Desmodorinae

1. Desmodora de Man

2. Odontolaimus de Man

3. Nudora Cobb

4. Rhinema Cobb .

5. Oistolaimus Ditlevsen.

6. Digitonchus Cobb

7. Anticyclus Cobb

8. Cophonchus Cobb

131

9. Anoncholaimus Cobb .

132

10. Asymmetrella Cobb

132

11. Isonemella Cobb

12. Synonema Cobb

13. Mesodorus Cobb

14. Iotadorus Cobb .

15. Ypsilon Cobb .

132

133

133

16. Monoposthia de Man .

133

134

17. Thoracostoma Marion .

18. Thoracostomopsis Ditlevsen

134

19. Discophora Villot

135

20. Onyx Cobb

21. Pharetrolaimus de Man

136

22. Catalaimus Cobb

136

23. Laxus Cobb

137

24. Xanthodora Cobb

137

25. Chonioluimus Ditlevsen

137

26. Dorylaimopsis Ditlevsen

Subfam. 3. Ironinat

1. Ironus Bastian .

2. Odontophora Bütschli

3. Mesonchium Cobb 
4. Ironella Cobb

5. Apodontium Cobb

6. Trissonchulus Cobb

7. Synodontium Cobb

8. Trigonolaimus Ditlevsen

9. Diodontolaimus Southern

10. Gonionchus Cobb

11. Dolicholaimus de Man

12. Syringolaimus de Man

13. Actinonema Cobb

Subfam. 4. Enoplinae

1. Enoplus Dujardin

2. Synonchium Cobb

3. Triodontolaimus de Man

4. Xyala Cobb

5. Selachinema Cobb

6. Fiacra Southern

7. Dignathonema Filipjev

8. Rhabdotoderma Marion

9. Cheironchus Cobb

Appendix to Oncholamidde

a. Heterocephalus Marion

b. Enoplostoma Marion .

c. Lasiomitus Marion

d. Rhabdocoma Cobb

\section{Order II. STRONGYLOIDEA}

Fam. 1. STRONGYLIDAE

Subfam. 1. Strongylinae

1. Strongylus Müller

1a. Subgenus Strongylus Railliet . . . . 151

1b. " Alfortia Railliet. . . . . 151

1c. , Delafondia Raillict . . . . 151

1d. „. Decrusia Lane . . . . . 151

2. Triodontophorus Looss . . . . . 152 
3. Craterostomum Boulenger . . . . . 152

4. Codiostomum Railliet \& Henry . . . . 152

5. Oesophagodontus Railliet \& Henry . . . 153

6. Equinurbia Lane . . . . . . 153

7. Choniangium Railliet, Henry \& Bauche . . 153

8. Ransomus Hall . . . . . . . 154

Subfam. 2. Trichoneminae

1. Trichonema Cobbold . . . . . . 154

1a. Subgenus Trichonema Le Roux . . . . 155

1b. " Cylicostomum Thle . . . . 155

lc. $\quad$, Cylicocyclus Ihle . . . . 156

1d. " Cylicocercus Ihle . . . . . 156

1e. „, Cylicodontophorus Thle . . . 156

2. Poteriostomum Quiel . . . . . . 156

3. Murshidia Lane . . . . . . . 157

4. Pteridopharynx Lane . . . . . . 157

5. Gyalocephalus Looss . . . . . . 158

6. Amira Lane . . . . . . . . 159

7. Quilonia Lane . . . . . . . . . 159

8. Bourgelatia Railliet, Henry \& Bauche . . . 160

9. Kiluluma Skrjabin . . . . . 160

10. Cylindropharynx Leiper . . . . . . 161

11. Trachypharynx Leiper . . . . . . 161

12. Eucyathostomum Molin . . . . . . 161

13. Deletrocephalus Diesing . . . . . 162

14. Cloacina v. Linstow . . . . . . . 162

15. Zoniolaimus Cobb . . . . . . 163

Subfam. 3. Oesophagostominae

1. Oesophagostomum Molin . . . . . 163

2. Ternidens Railliet \& Henry . . . 164

3. Chabertia Railliet \& Henry . . . . 164

Subfam. 4. Stephanurinae

1. Stephanurus Diesing . . . . . 165

Subfam. 5. Syngaminat

1. Syngamus v. Siebold . . . . . 165

2. Cyathostoma E. Blanchard . . . . 166 
Fam. 2. ANCYLOSTOMIDAE

Subfam. 1. Ancrlostominae

1. Ancylostoma (Dubini) Creplin

PAGE

2. Galoncus Railliet

167

3. Agriostomum Railliet .

4. Strongylacantha van Beneden

\section{Subfam. 2. Necatorinae}

1. Necator Stiles

2. Brachyclonus Railliet \& Henry

3. Globocephatus Molin .

4. Bunostomum Railliet .

5. Monodontus Molin

6. Gaigeria Railliet \& Henry

7. Uncinaria Frölich

8. Tetragomphius Baylis \& Daubney

9. Acheilostoma Leiper .

10. Grammocephalus Railliet \& Henry

11. Bathmostomum Railliet \& Henry .

Fam. 3. DIAPHANOCEPHALIDAE

1. Diaphanocephalus Diesing .

2. Katicephalus Molin .

Fam, 4. METASTRONGYLIDAE

1. Metastrongylus Molin .

2. Choerostrongylus Gedoelst .

3. Dictyocaulus Railliet \& Henry . . . . 176

4. Synthetocaulus Railliet \& Henry . . . . 176

5. Haemostrongylus Railliet \& Henry . . . 177

6. Troglostrongylus Verers . . . . . 177

7. Crenosoma Molin . . . . . . 177

8. Pseudalius Dujardin . . . . . . 178

9. Stenurus Dujardin . . . . . . 178

10. Filaroides van Beneden . . . . . 178 
Fam. 5. TRICHOSTRONGYLIDAE

Subfam. 1. Trichostrongylinae

1. Trichostrongylus Looss

2. Cooperia Ransom . . . . . . 180

3. Travassosius Khalil . . . . . 180

4. Graphidium Railliet \& Henry . . . . 180

5. Graphidioides Cameron . . . . . 181

6. Obeliscoides Graybill . . . . . . $18 \mathrm{I}$

7. Hyostrongylus Hall . . . . . . . 182

8. Ostertagia Ransom . . . . . . . 182

9. Ornithostrongylus Travassos . . . . 183

10. Trichohelix Ortlepp . . . . . . 183

11. Oswaldocruzia Travassos . . . . . . 183

12. Molineus Cameron . . . . . . . 184

13. Haemonchus Cobb . . . . . . 184

14. Nematodirus Ransom . . . . . 185

15. Mecistocirrus Railliet \& Henry . . . . 185

16. Histiostrongylus Molin . . . . . 186

Subfam. 2. Heligmosominae

1. Heligmosomum Railliet \& Henry . . . . 187

2. Heligmosomoides Hall . . . . . 187

3. Nematospira Walton . . . . . . 188

4. Heligmostrongylus Travassos . . . . 188

5. Nippostrongylus Lane . . . . . . 189

6. Viannaia Travassos . . . . . . . 189

7. Viannella Travassos . . . . . . . 189

8. Impalaia Monnig . . . . . . 190

Appendix to Heligmosominae

9. Citellinema Hall . . . . . . 190

10. Warrenius Hall . . ... . . . 191

11. Ollulanus Leuckart . . . . . . 191

Fam. 6. AMIDOSTOMIDAE

1. Amidostomum Railliet \& Henry . . . 192

2. Epomidiostomum Skrjabin . . . . . 192

3. Amphibiophilus Skrjabin . . . . . 193 


\section{Order III. FILARIOIDEA}

Fam. 1. FILARIIDAE

Subfam. 1. Filarinate

1. Filaria Mïller

2. Dirofilaria Railliet \& Henry

3. Acanthocheilonema Cobbold

4. Dipetalonema Diesing . . . . . 196

5. Wuchereria Silva Araujo . . . . . 196

6. Litomosa Yorke \& Maplestone . . . . . 197

7. Hamatospiculum Skrjabin . . . . . 198

8. Foleyella Seurat . . . . . . 198

9. Onchocerca Diesing . . . . . . 198

10. Elaeophora Railliet \& Henry . . . . 199

11. Katanga Yorke \& Maplestone . . . . 199

12. Lemdana Seurat . . . . . . . 199

13. Icosiella Seurat. . . . . . . 200

14. Politospiculum Skrjabin . . . . . 200

15. Setaria Viborg . . . • • . . 200

16. Loa Stiles . . . • • • . 201

17. Micipsella Seurat . . . . . . 202

18. Pelecitus Railliet \& Henry . . . . . 202

Subfam. 2. Diplotriaeninae

1. Diplotriaena Railliet \& Henry . . . . 203

2. Dicheilonema Diesing . . . . . 203

3. Hastospiculum Skrjabin . . . . . 204

4. Serratospiculum Skrjabin . . . . . 204

Subfam. 3. Aproctinae

1. A procta v. Linstow . . . . . 205

2. Thamugadia Seurat . . . . . 206

3. Eufilaria Seurat . . . . . . 206

4. Splendidofilaria Skrjabin . . . . . . 206

5. Eucamptus Dujardin . . . . . . 206

Appendix to Filarindae

a. Solenonema Diesing . . . . . . 207

b. Tetracheilonema Diesing . . . . . 207

c. Tricheilonema Diesing . . . . . 207 
d. Monopetalonema Diesing

e. Tipasella Seurat

207

f. Microfilaria Cobbold .

208

g. Dermofilaria Rivolta .

208

\section{Fam. 2. PHILOMETRIDAE}

1. Philometra Costa

2. Micropleura v. Linstow

3. Dracunculus Kniphof

\section{Fam. 3. SPIRURIDAE}

Subfam. 1. SpIRURINAE

1. Spirura E. Blanchard

2. Protospirura Seurat .

3. Habronema Diesing

4. Parabronema Baylis

5. Hartertia Seurat

6. Histiocephalus Diesing

7. IIadjelia Seurat 213

8. Hedruris Nitzsch 213

9. Desmidocerca Skrjabin 214

Subfam. 2. Arduenninat

1. Arduenna Railliet \& Henry

2. Simondsia Cobbold .

3. Physocephalus Diesing

4. Spirocerca Railliet \& Henry 215

5. Cylicospirura Vevers . 216

6. Streptopharagus Blanc 216

7. Gongylonema Molin . 216

Subfam. 3. Acuaritnae

1. Acuaria Bremser

1a. Subgenus Acuaria

1b. " Cheilospirura (Diesing) Railliet, Henry \& Sisoff

1c. „ Dispharynx Railliet, Henry \& Sisoff 218

1d. " Synhimantus Railliet, Henry \& Sisoff 218

le. ", Cosmocephalus Molin . 
1f. Subgenus Echinuria Soloviev . . . . 219

1g. . Rusguniella Seurat . . . . 219

1h. . Seuratia Skrjabin . . . . 219

2. Chevreuxia Seurat . . . . . . 219

3. Streptocara Railliet, Henry \& Sisoff . . . 220

4. Sciadiocara Skrjabin . . . . . . 220

Appendix to Acuarinate

5. Tropisurus Diesing . • • . • . 220

6. Crassicanda Leiper \& Atkinson . . . . 221

Subfam. 4. Physalopterinae

1. Physaloptera Rudolphi . . . . . 222

2. Heliconema Travassos . . • . . 222

3. Thubunaea Seurat . . . • . . 223

4. Proleptus Dujardin . . . . • . 223

5. Ochetocephalus v. Linstow . . . . . 223

Subfam. 5. ThelazunaE

1. Thelazia Bose

2. Rhabdochona Railliet. . . . . . 224

3. Oxyspirura v. Drasehe . . . • . 224

4. Cystidicola Fischer v. Waldheim . . • . 225

5. Ceratospira Sehneider . . . . . 225

6. Viguiera Seurat . . . . . . 225

7. Schistorophus Railliet . . . . . . 226

8. Serticeps Railliet . . . . . . 226

Appendix to Tilelazirnae

9. Spinitectus Fourment . . . . . 227

10. Rictularia Frölich . . . . . . 227

11. Rictularioides Hall . . . . . . 227

12. Pneumonema Johnston . . . . . 228

13. Echinonema v. Linstow . . . . . 228

Appendix to Spiruridae

a. Osterus Hall . . . . . . . 229

b. Ascarops van Beneden . . . . . 229

c. Cephalacanthus Diesing . . . . . 229

d. Mastophorus Diesing . . . . . . 229 
Fam. 4. CAMALLANIDAE

1. Camallanus Railliet \& Henry

2. Camallanides Baylis \& Daubney . . . . 230

3. Procamallanus Baylis . . . . . 230

Fam. 5. CUCULLANIDAE

1. Cucullanus Müller

2. Dacnitoides Ward \& Magath

3. Seuratum Hall .

Fam. 6. GNATHOSTOMIDAE

Subfam. 1. GNathostominae

1. Gnathostoma Owen

232

2. Echinocephalus Molin

3. Tanqua R. Blanchard

Subfam. 2. SPIROXYINAE

I. Spiroxys Schneider

234

Aprendix to Gnathostomidae

a. Ancyracanthus Diesing

- 234

b. Ancyracanthopsis Diesing . . . . . 234

c. Elaphocephalus Molin

235

Appendix to Filarioidea

a. Haplonema Ward \& Magath . . ... : . 235

b. Ascarophis van Beneden . . . . . 235

\section{Order.IV. DIOCTOPHYMOIDEA}

Fam. 1. DIOCTOPHYMIDAE

1. Dioctophyme Collet-Meygret . . . . 236

2. Eustrongylides Jägerskiöld . • .nsı • . 236

3. Hystrichis Dujardin . . . . . 237

\section{Order V. TRICHINELLOIDEA}

Fam. 1. TRICHINELLIDAE

Subfam. 1. TrichinellinaE

1. Trichinella Railliet 
Subfam. 2. Trichurinae

1. Trichuris Roederer

2. Capillaria Zeder

3. Hepaticola Hall

Subfam. 3. Trichosomoidinae

1. Trichosomoides Railliet

\section{Appendix to Nematoda}

A. Fam. DRILONEMIDAE

1. Drilonema Pierantoni

2. Pierantonia nom. nov.

3. Pharyngonema Pierantoni

4. Dicelis Dujardin

5. Synoecnema Magalhães

B. Genera Incertae Sedis

1. Agamonematoideum Diesing

2. Amblyura Ehrenberg .

3. Anguillina Hammersehmidt

4. Aphelenchoides Fischer

5. Buddenbrockia Schröder

6. Calyptronema Marion

7. Choronema Cobb

8. Cystoopsis Wagner . . . . . . 244

9. Dikentrocephalus Wedl . . . . . 244

10. Diplolaimus v. Linstow . . . . . 245

11. Eubostrichus Greeff . . . . . . 245

12. Eustoma van Beneden . . . . . 246

13. Filarina Hammersehmidt . . . . . 246

14. Labyrinthostoma Cobb . . . . . 246

15. Lineola Kölliker . . . . . . . 246

16. Lumbricicola Friedländer . . . . . 246

17. Mitrephorus v. Linstow . . . . . . 246

18. Nema Leidy . . . . . . . 247

19. Phacelura Ehrenberg . . . . . . 247

20. Phanoglene Nordmann . . . . . 247 
21. Phlyctainophora Steiner

22. Piguris Schlotthauber

23. Pontonema Leidy

24. Potamonema Leidy

25. Prothelmins v. Linstow

245

26. Pseudochromadora Daday

27. Pierygifer v. Linstow

249

28. Scolecophilus Baylis \& Daubney

29. Stenodes Dujardin

30. Uracanthus Diesing .

31. Urolabes Carter

C. Unrecognizable Forms

1. Chaos Linnaeus

2. Crinon Chabert

3. Diplasia von Holten .

251

4. Discophorus Mehlis

252

5. Ditrachyceros Hermanu

252

6. Liorhynchus Rudolphi

252

7. Needhamia Carus

252

8. Onchophora Krøye

252

9. Pontamonema v. Linstow

253

10. Proboscidea (Bruguière) Cuvier . . . . 253

11. Protostrongylus Leiper

253

12. Rhytis Mayer

253

13. Sclerotrichum Rudolphi

253

14. Spherurus Rafinesque . . . . . 254

15. Trachynema Cobb . . . . . . 254

16. Vetteria Jägerskiöld . . . . . . 254

17. Vibrio Müller . . . . . . . . 254

18. Dyacanthos Stiebel . . . . . . 255

19. Fictitium Diesing . . . . . . 255

20. Furia Linnaeus . . . . . . 255

\section{Collective Names}

1. Agamofilaria Stiles

2. Agamonema Diesing .

3. Agamonematodum Diesing . 
4. Agamospirura Henry \& Sisoff . . . . . 255

5. Capsularia Zeder . . . . . . . 255

6. Dubium Rudolphi . . . . . . 255

7. Filocapsularia Deslongchamps . . . . 255

8. Helmins Schlotthauber . . . . . 255

9. Merinthoidum Kraemer . . . . . 255

10. Nematodum Diesing . . . . . . . 255

11. Nematoideum Diesing . . . . . 255 


\section{NEMATODA}

Order I. ASCAROIdeA Railliet \& Henry, 1915.

Free-living or parasitic forms having normally three lips, of which one is dorsal and two subventral. In certain cases the lips may be much reduced or absent.

\section{Fam. 1. ASCARIDAE Cobbold, 1864.}

Parasitic forms. Polymyarian. Lips well developed, bearing papillae and sometimes alternating with three interlabia. Buccal cavity absent. Reproductive organs highly developed. Male with two spicules. An accessory piece present or absent. Uterine branches parallel. Oviparous. Eggs very numerous, with unsegmented contents when laid.

\section{Subfam. 1. ASCARINAE Travassos, 1913.}

Oesophagus without well-marked ventriculus, sometimes with a muscular bulb. Spicules equal or subequal. Accessory piece absent. Vagina and uterus run posteriorly from the vulva.

\section{Ascaris L., 1758.}

Syn. Stomachida Pereboom, 1780; Fusaria Zeder,.1800; Lombricoides Mérat, 1821.

Cervical alae absent. Lips with dentigerous ridges. Interlabia, if present, extremely reduced. No interlabial grooves at bases of lips. Male with five or six pairs of postanal papillae, the anterior pair or anterior pairs having double terminations. Numerous irregularly-arranged preanal papillae. Spicules non-alate, tubular, relatively short and stout. Vulva near middle of body or anterior to it. Uterine branches two.

Hab. Small intestine of Mammals.

Genotype: A. lumbricoides L., 1758.

Linnaeus, 1758, Systema Naturae, i, 644, 648.

2. Ophidascaris Baylis, 1921.

Cervical alae absent. Lips almost square. Dorsal lip slightly smaller than ventro-lateral lips. Dentigerous ridges SYN. NEM. 
present. Interlabia usually well developed. Deep transverse interlabial grooves run from the interlabia partially round the bases of the lips. Oesophagus without bulb or ventriculus. Male with four to six pairs of postanal papillae, the most anterior pair frequently having double terminations. Preanal papillae numerous. Spicules subequal, alate. Vulva usually in posterior half of body. Genital organs in both sexes usually confined to posterior region of body, which often shows a fusiform thickening. Uterine branches two.

Hab. Alimentary canal of Reptiles.

Genotype : O. [Ascaris] filaria (Dujardin, 1845).

Dujardin, 1845, Histoire naturelle des Helminthes, Paris, 177, 653 ; Baylis, 1921, Parasitol., xii, 412.

\section{Polydelphis Dujardin, 1845.}

Syn. Hexametra 'Travassos, 1920.

Cervical alae absent. Lips more or less bexagonal, frequently longer than broad, ustally broader at the base than at the free edge. Dorsal lip usually smaller than ventrolateral lips. Pulp of ventro-lateral lips asymmetrical. Interlabia absent. No interlabial grooves at bases of lips. Oesophagus without bulb or ventrieulus. A rudimentary intestinal caecum occasionally present. Spicules subequal. Candal papillae of male as in Ophidascaris. Vulva usually in anterior region of body, rarely behind the middle. Uterine branches four or six.

Hab. Alimentary canal of Reptiles.

Genotype: P. [Ascaris] anoura. Dujardin, 1845.

Dujardin, 1845, Histoire naturelle des Helminthes, Paris, 221 (as subgenus); Baylis, 1921, Parasitol., xii, 418; Baylis \& Daubney, 1923, Rec. Ind. Mus., xxv, 554.

\section{Toxocara Stiles, 1905 .}

Syn. Belascaris Leiper, 1907.

Cervical alae present, coarsely striated. Body bent ventrally anteriorly. Lips with pulp forming two distinct lateral lobes and an minpaired internal lobe. Interlabia absent. Oesophagus with distinct muscular bulb posteriorly. Tail of male with marked terminal digitiform appendage. Caudal alae more or less well developed. On each side a group of five postanal papillae on the terminal appendage (two subdorsal, one lateral, two subventral), one double subventral papilla between cloaca and base of appendage, and about twenty preanal papillae. Spicules subequal, alate. Vulva towards anterior fourth of body. Coils of female genital tubes extend throughout almost whole length of body. Common trunk of 
uterus relatively long. Eggs globular or subglobular, with a thin shell, the surface of which is pitted.

Hab. Small intestine of carnivorous Mammals.

Genotype : T. [Lumbricus] canis (Werner, 1782).

Werner, 1782, Vermium intestinalium brevis expositionis continuatio, Leipzig, 11; Stiles, in Stiles \& Hassall, 1905, U.S. Dept. Agric., Bur. Anim. Indust. Bull. 79, 150; Leiper, 1907, Brit. Med. Journ., June 1, 1297 ; Railliet \& Henry, 1911, Compt. rend. Soc. Biol., Paris, lxx, 12; Stiles \& Brown, 1924, Journ. Parasitol., xi, 92.

According to Stiles and Brown (1924), Werner's Lumbricus canis is a recognizable species, because Rudolphi recognized it and renamed it Ascaris marginata. If this reasoning is sound, $L$. canis can be taken, as it was taken by Stiles (1905), as the type of the genus to which Belascaris mystax (Zeder, 1800) also belongs. Belascaris thus becomes a synonym of Toxocara.

\section{Toxascaris Leiper, 1907.}

Cervical alae present, finely striated. . Body bent dorsally anteriorly. Lips as in Belascaris, but with anterior lobules marked off from lobes by a deep groove, broad and bilobed at their extremities. Interlabia absent. Oesophagus without bulb. Tail of male conical, without digitiform appendage. Caudal alae absent. On each side a group of five postanal papillae near tip of tail (two subdorsal, one lateral, two subventral). A double subventral papilla between these and the cloaca, and a row of at least twenty-five papillae, commencing with a papilla behind the cloaca, the second of this series being at the level of the cloacal opening. Spicules subequal, nonalate. Vulva towards anterior third of body. Coils of female genital tubes lie between vulva and posterior end of body. Common truuk of uterus relatively short. Eggs subglobular, with thick, smooth shell.

Hab. Small intestine of earnivorous Mammals.

Genotype: T. [Ascaris] leonina (v. Linstow, 1902).

v. Linstow, 1902, Arch.f. mikr. Anat., lx, 217 ; Leiper, 1907, Brit. Med. Journ., June 1, 1297; Railliet \& Henry, 1911, Compt. rend. Soc. Biol., Paris, lxx, 12.

\section{Lagochilascaris Leiper, 1909.}

Lateral alae present throughout the whole length of the body. Lips separated by a groove from the body. Free edge of each lip deeply indented in the middle. Well-developed interlabia present. Oesophagus simple. Tail of male bluntly conical, slightly curved ventrally. Five pairs of postanal papillae, those of the most anterior pair being large and having 
double terminations. At least twenty-four pairs of preanal papillae. Spieules subequal, non-alate. Vulva in front of middle of body. Vagina runs anteriorly for a short distanee, then turns posteriorly. Eggs globular, with thick, pitted shells.

Hab. Alimentary canal (?) of carnivorous Mammals.

Genotype: L. minor Leiper, 1909.

Leiper, 1909, Abstr. Proc. Zool. Soc. Lond., No. 74, 35; 1909, Proc. Zool. Soc. Lond., 742; 1913, Trans. Soc. Trop. Med. Hyg., vi, 265; Fantham, Stephens \& Theobald, 1916, Animal Parasites of Man, London, 467.

\section{Orneoascaris Skrjabin, 1916.}

Cervical alae apparently absent. Lips large, with dentigerous ridges. Interlabia absent. Oesophagus simple. Tail of male with wide alae and longitudinally and transversely furrowed on its ventral surface. Postanal papillae four pairs, sessile. Preanal papillae perhmeulate, not numerous. Spicules equal, transparent. Vulva in anterior half of body. Eggs large and oval.

Hab. Alimentary canal of Amphibia.

Genotype: O. chrysanthemoides Skrjabin, 1916.

Skrjabin, 1916, Sci. Res. Zool. Exp. Brit. E. Africa (Dogiel \& Sokolow), 1914, Petrograd, i (4), 50, 124.

\section{Trispiculascaris Skrjabin, 1916.}

Lips large, with auricular outgrowths at the sides. Dentigerous ridges and interlabia present. No ventriculus or oesophageal or intestinal eaeca. Tail of male eurved, with wide alae and very few preanal and postanal papillae, arranged in single lateral rows. Spicules equal, slender. An accessory picce present. Tail of female straight, eonically pointed. Vulva in anterior half of body.

Hab. Alimentary eanal of Reptiles.

Genotype: T. trispiculascaris Travassos, $1920 \quad(=T$. helicina (Molin, 1860) of Skrjabin, 1916).

Skrjabin, 1916, Sci. Res. Zool. Exp. Brit. E. Africa (Dogiel \& Sokolow), 1914, Petrograd, i (4), 48, 123; Travassos, 1920, Arch. Esc. Sup. Agric.e Med. Vet., Nietheroy, iv, 15.

Subfam. 2. ANISAKINAE Railliet \& Henry, 1912, emend. Baylis, 1920.

Oesophagus may or may not be divided into an anterior museular portion and a postcrior ventriculus of different histologieal structure, or a museular bulb. When a ventri- 
culus is absent, and frequently when it is present, there is an anterior caecum springing from the intestine and lying alongside of the oesophagus. A posterior glandular caecum, or occasionally several such caeca, some of which may be directed anteriorly, may also be developed in connection with the ventriculus. Parasitic in the alimentary canal of Vertebrates, the hosts being generally aquatic or fish-eating animals.

The subfamilies Crossophorinae and Goeziinae were proposed by Baylis (1920, Parasitol., xii, 263) for the genera Crossophorus and Goezia respectively, while the subfamily Heterocheilinae Railliet \& Henry, 1912, was restricted to the genera Hetero. cheilus (Lobocephalus) and Typhlophoros. It appears doubtful whether sufficient characters exist to warrant the separation of these subfamilies from the Anisakinae. The genera concerned are therefore now referred to the latter subfamily. For the two subfamilies Anisakinae and Heterocheilinae of Railliet \& Henry (1912), which we regard as forming a single group, we have preferred to retain the name Anisakinae, with a well-known genus as its type. In any case the name Heterocheilinae falls into synonymy together with that of its type-genus.

\section{Anisakis Dujardin, 1845.}

Syn. Peritrachelins Diesing, 1851; Conocephalus Diesing, 1861.

Lips with dentigerous ridges. Interlabia absent. Oesophagus with an oblong or sigmoid ventriculus. No oesophageal or intestinal caeca. Spicules sometimes unequal.

Hab. Stomach and intestine of marine Mammals.

Genotype: A. [Ascaris] dussumieri (van Beneden, 1870).

Dujardin, 1845, Histoire naturelle des Helminthes, Paris, 151 (as subgenus); Stiles \& Hassall, 1899, Rep. Fur Seal Invest., Washington, Part III; Baylis, 1920, Parasitol., xii, 260.

\section{Raphidascaris Railliet \& Henry, 1915.}

Syn. Hysterothylacium Ward \& Magath, 1916.

Lips withont dentigerous ridges. Interlabia present. Ocsophagus with small ventriculus, from which springs a small posterior caecum. No intestinal caecum.

Hab. Stomach and intestine of Fishes.

Genotype : R. [Ascaris] acus (Bloch, 1779).

Bloch, 1779, Beschäft. Berl. Ges. Naturf. Fr., iv, 544; Railliet \& Henry, 1915, Bull. Soc. Path. exot., Paris, viii, 271; Ward \& Magath, 1916, Journ. Parasitol., iii, 63; Baylis, 1920, Parasitol., xii, 261. 


\section{Porrocaecum Railliet \& Henry, 1912.}

Syn. Terranova Leiper \& Atkinson, 1914.

Lips with dentigerous ridges. Interlabia usnally present. Oesophagus with oblong ventriculus, which is short in the genotype but in other species often long and bent at an angle, so as to open into the intestine laterally. An intestinal caecum present. No oesophageal caecum. An accessory piece is rarely present.

Hab. Intestine of Birds, marine Mammals and Fishes.

Genotype: P. [Ascaris] crassum (Desl., 1824).

Deslongehamps, 1824, Encycl. Méthodique, Paris, ii, 89; Railliet \& Henry, 1912, Bull. Soc. Path. exot., Paris, v, 256; Baylis, 1920, Parasitol., xii, 261.

\section{Contracaecum Railliet \& Henry, 1912.}

Syn. Kathleena Leiper \& Atkinson, 1914.

Lips without dentigerous ridges. Interlabia present, usually very well developed. Oesophagus with reduced ventriculus, giving off a posterior caecum. An intestinal eaecum present.

Hab. Intestine of fish-eating Mammals and Birds, and of Fishes.

Genotype : C. [Ascaris] spiculigerum (Rud., 1809).

Rudolphi, 1809, Entozoorum Historia Naturalis, ii, 168; Railliet \& Henry, 1912, Bull. Soc. Path. exot., Paris, v, 256; Baylis, 1920, Parasitol., xii, 261.

5. Cloeoascaris Baylis, 1923.

Each lip with a pair of large conieal teeth on its inner surface. Interlabia absent. A eollar-like fold of cuticle surrounding the neck, and between this and the bases of the lips an area covered with small spines. Oesophagus with a reduced ventriculus giving off a posterior caecum. An intestinal caecum present. Vulva in anterior half of body.

Hab. Alimentary canal of semi-aquatic carnivorous Mammals (one species known).

Genotype : C. spinicollis Baylis, 1923.

Baylis, 1923, Ann. Mag. Nat. Hist., (9) xi, 459, 463.

\section{Galeiceps Railliet, 1916.}

Head apparently with three lips, of which the dorsal is bilobed, and each bears one or two teeth on its imner surface. Behind the lips a collar-like cuticular fold. Interlabia absent. Structure of alimentary canal not clescribed. 
Hab. Intestine of a semi-aquatic Mammal (one species known).

Genotype: G. [Ancyracanthus] cucullus (v. Linstow, 1899).

v. Linstow, 1899, Mitt. Zool. Mus., Berlin, i, 19; Railliet, 1916, Journ. Parasitol., ii, 103.

Ancyracanthus cucullus v. Linstow, 1899, for which Raillict proposed the genus Galeiceps, referred by him to the family Thelaziidae, appears to be very closely related to Cloeoascaris. The two dorsal buccal swellings described by v. Linstow appear to be two lobes of a single dorsal lip. No mention is made of spines between the bases of the lips and the cuticular collar. Possibly the re-examination of v. Linstow's species may show that Cloeoascaris is synonymous with Galeiceps.

\section{Paranisakis Baylis, 1923.}

Lips with dentigerous ridges. Interlabia present. Oesophagus with a ventriculus, but no oesophageal or intestinal caeca.

Hab. Intestine of Fishes.

Genotype : P. squatinae Baylis, 1923.

Baylis, 1923, Parasitol., xv, 8.

The genus Paranisakis resembles Anisakis in having an oesophageal ventriculus, but no caeca. It differs, however, in the presence of interlabia and dentigerous ridges. The characters of the head indicate its very close relationship to Contracaecum.

\section{Dujardinia Gedoelst, 1916.}

I.ips without dentigerous ridges, but with the cuticle of their internal surfaces produced into large tooth-like structures, apparently capable of being interlocked. These structures are carried by three main cuticular lobes on the anterior border of each lip. Interlabia present. Well-marked interlabial grooves run from them to the bases of the lips. Oesophagus with a small spherical bulb. No oesophageal caecum. An intestinal caecum present. Vagina long and slender. Eggs subglobular, with very thin membranous shell.

Hab. Alimentary canal of aquatic Vertebrates (Crocodiles, Fishes, Dugong).

Genotype : D. [Ascaris] helicina (Molin, 1860).

Molin, 1860, Sitz. k. Akad. Wiss., Wien, xl, 337 ; v. Drasche, 1883, Verh. k. k. Zool.-bot. Ges., Wien, xxxii, 130; Gedoelst, 1916, Rev. Zool. Afric., Brussels, v (1), 18, 21 ; Baylis, 1920, Parasitol., xv, 223.

\section{Multicaecum Baylis, 1923.}

Lips with dentigerous ridges. Small interlabia present. Well-marked interlabial grooves run from them to the bases 
of the lips. Oesophagus with a small ventriculus, from which spring two anterior and three posterior cacea. An intestinal caecum present. An accessory piece present.

Hab. Alimentary canal of Crocodiles (one species known).

Genotype: M. [Ascaris] agile (Wedl, 1862).

Wedl, 1862, Silz. h. Akad. Wiss., Wien, xliv, 467; Baylis, 1923, Parasitol., xv, 230.

\section{Angusticaecum Baylis, 1920.}

Lips with dentigerous ridges. Interlabia absent. Ocsophagus without rentriculus or distinet bulb. No oesophageal caecum. A long slender intestinal caecum present.

Hab. Intestine of land Tortoises and (?) Batrachians.

Genotype: A. [Ascaris] holopterum Rud., 1819.

Rudolphi, 1819, Entozoorum Synopsis, 53, 295; Baylis, 1920, Parasitol., xii, 262.

Baylis (1920) referred Porrocaecum numidicum Seurat, 1917, from Rana, to this genus. In spite, however, of the stated absence of interlabia it seems more probable that it is referable to Amplicaecum. We have seen specimens belonging apparently to the latter genus from a frog and from a crocodile. Those from the frog were similar to, though probably not identical with, Seurat's species.

\section{Amplicaecum Baylis, 1920.}

Lips with dentigerous ridges. Small interlabia present. Oesophagus without ventriculus or distinct bulb. No oesophageal caecum. A wide intestinal caecum present.

Hab. Alimentary canal of carnivorous Birds and Reptiles.

Genotype: A. [Ascaris] colurum (Baylis, 1919).

Baylis, 1919, Ann. Mag. Nat. Hist., (9) iii, 457; 1920, Parasitol., xii, 262.

12. Crossophorus Ehrbg., in Hemp. \& Ehrbg., I82S.

Lips separated from neck by a distinct constriction, which is occupied by a collar consisting apparently of a double row of fimbriae. In reality these fimbriae form a single endless chain, which doubles on itself at the centre of the base of each lip externally and passes across the inner surface of the lip. In addition to these each lip also has an interrupted dentigerous ridge. No interlabia. Oesophagus with "gizzard " anteriorly, containing a chitinoid masticatory apparatus, and with a posterior inuscular bulb. 'Two long intestinal caeca present. No oesophageal caecum. Tail of male very blunt. Postanal papillae in two parallel rows on either side. Preanal papillae 
immediately in front of cloaca also in two parallel rows, and more anteriorly a single row on each side. Spicules equal, alate, transversely striated. An accessory piece present. Tail of female conically pointed. Vulva in the middle third of the body. Uterine branches opposed. Eggs oval, with moderately thick, smooth shells.

Hab. Alimentary canal of Hyrax.

Genotype : C. collaris Ehrbg., in Hemp. \& Ehrbg., 1828.

Ehrenberg, in Hemprich \& Ehrenberg, 1828, Symbolae physicae, Pars Zoologica, decas prima (Mammalia); Baylis, 1919, Ann. Mag. Nat. Hist., (9) iv, 343; Neveu-Lemaire, 1921, Bull. Soc. Path. exot., Paris, xiv, 390.

13. Goezia Zeder, 1800 .

Syn. Cochlus Zeder, 1803; Prionoderma Rud., 1810; Lecanocephalus Diesing, 1839.

Lips flattened from in front and expanded outwards, separated from body by a constriction. Cuticle with a series of transverse rings bearing backwardly-directed spines on their posterior edges. Oesophagus slightly constricted in the middle and swollen into a bulb behind, giving off posteriorly a long caecum. A short intestinal caecum present. Tail rounded and in both sexes prolonged into an appendage. Spicules subequal. Vulva a little in front of the middle of the body. Eggs globular.

Hab. Alimentary canal of Fishes.

Genotype: G. [Cucullanus] ascaroides (Goeze, 1782).

Goeze, 1782, Naturgeschichte der Eingeweidewürmer, Blaukenburg, 40, 134; Zeder, 1800, Erster Nachtrag zur Naturgeschichte der Eingeweidewürmer, Leipzig, 6, 96; Railliet \& Henry, 1915 Bull. Soc. Path. exot., Paris, siii, 270.

\section{Acanthocheilus Molin, 1858.}

Lips somewhat retractile, each with two pointed processes anteriorly and with two pairs of sharp teeth on its inner surface. Oesophagus with a spherical posterior bulb and a fusiform prebulbar swelling. An intestinal caecum present. Tail in both sexes conical. Male with preanal papillae in two rows on each side. Spicules short, with terminal knobs. Vulva in anterior region of body.

Hab. Intestine or stomach of Sharks and Dogfish.

Genotype: A. quadridentatus Molin, 1858.

Molin, 1858, Sitz. k. Akad. Wiss., Wien, xxx, 154; 1861, Denkschr. k. Aliad. Wiss., Wien, xix, 313; Örley, 1885, Termes. Fiiz., Budapest, ix, 102, 217 ; Linton, 1900, Bull. U.S. Fish. Comm., xix, 303. 
15. Lobocephalus Diesing, 1838.

Syn. Heterocheilus Diesing, 1839.

Lips bilobed, two of them truncate in front, the third broader and somewhat longer. Behind the lips a cuticular - collar composed of nine longitudinal folds. Three of these folds large, alternating with pairs of smaller folds. Oesophagus with a small distinet bulb. An intestinal caecum present. Tail of male pointed. Spicules alate. Tail of female tapering. Vulva apparently posterior. Eggs oval.

Hab. Stomach and small intestine of Manatee (one species known).

Genotype: L. heterolobus Dies., 1838 (= Heterocheilus truncatus Dies., 1839).

Diesing, 1839, Ber. u. d. Versamml. deutsch. Naturf. u. Aerzte in Prag, 189; 1839, Ann. Wien. Mus. Naturg., ii, 229; Stiles \& Hassall, 1899, Rep. Fur Seal Invest., Washington, Part III, 107.

16. Typhlophoros v. Linstow, 1906.

Lateral alae present. Lips triangular, narrowed at base, with pulp widened in front. Behind the lips a cuticular collar of sixteen transversely striated longitudinal folds. An intestinal caecum present. Tail of male with four pairs of preanal papillae. Spicules equal. Tail of female with two rounded preanal projections. Vulva somewhat in front of middle of body. Eggs thick-shelled.

Hab. Stomach of Gharial (one species known).

Genotype: T. lamellaris $\mathrm{v}$. Linstow, 1906.

v. Linstow, 1906, Journ. and Proc. Asiat. Soc. Bengal, ii, 270.

17. Heligmus Dujardin, 1845.

Lips rounded, not very distinet. Oesophagus club-shaped, with a ventriculus. Tail of male recurved, with a donble row of twelve to thirteen ventral papillae. A single, very long, tubular, flexible, transversely striated and broadly alate spienle. Vulva towards anterior third of body.

Hab. Intestine of Fishes (one species known).

Genotype: H. longicirrus Dujardin, 1845.

Dujardin, 1845, Histoire naturelle des Helminthes, Paris, 136,145 .

From Dujardin's description it appears possible that this genus may be a member of the subfamily Anisakinae, but the eharacters given are insufficient to establish definitely its position. 
Fam. 2. HETERAKIDAE Railliet \& Henry, 1914.

Parasitic forms. Polymyarian. Lips may be well defined, or so reduced as to appear absent. A buccal capsule may be present or absent. In the absence of a buccal capsule, the anterior portion of the oesophagus is usually differentiated as a pharynx. Except in Ascaridia, a posterior oesophageal bulb is present. There is a more or less well-developed preanal sucker in the malc, with or without a chitinoid border. Reproductive organs highly developed. Spicules usually two (occasionally one or both may be imperfectly chitinized, or absent). Vulva typically near the middle of the body, occasionally posterior.

\section{Subfam. 1. HETERAKINAE Railliet \& Henry, 1912.}

Lips well defined. Buccal capsule absent. Oesophagus with a pharynx and a posterior bulb, except in Ascaridia. Preanal sucker nearly circular, with chitinoid border. Vulva in the middle of the body or slightly antcrior to it. Eggs usually unsegmented when laid.

\section{Heterakis Dujardin, 1845.}

Syn. Ganguleterakis Lane, 1914; Gireterakis Lane, 1917.

Lips without "cordons." Oesophagus with a short pharynx and a distinct subglobular bulb. Caudal alae of male cxtremely well developed, and supported by pedunculate papillae. Spicules unequal or subequal. No accessory piece. Branches of uterus either actually or apparently opposed. Eggs with thick shell and unsegmented contents.

Hab. Alimentary canal of Birds and Mammals.

Genotype : H. [Ascaris] papillosa (Bloch, 1782).

Bloch, 1782, Abhandlung von der Erzeugung der Eingeweidewürmer, Berlin, 32; Dujardin, 1845, Histoire naturelle des Helminthes, Paris, 136, 222 ; Travassos, 1913, Mem. Inst. Osw. Cruz, Rio de Janeiro, v, 274; Lane, 1914, Ind. Journ. Med. Res., ii, 656, 660, and 1917, iv, 754, 758, 764.

\section{Pseudaspidodera Baylis \& Daubney, 1922.}

Lips with "cordons," opening in pairs at the interlabial spaces, diverging and recurrent, ending blindly on outer surface of lips. Oesophagus as in Heterakis, with a very short pharynx and a well-developed posterior pyriform bulb. Caudal alae of male well developed, and supported by pedunculate papillae. Spicules unequal and dissimilar, the right long and slender, the left short, stout and alate, with a barbed tip. No accessory piece. Uterine branches opposed. Eggs thin-shelled, with a slight internal thickening at one pole. 
Hab. Alimentary canal of Pea-fowl (one species known).

Genotype: P. pavonis Baylis \& Daubney, 1922.

Baylis \& Daubney, 1922, Mem. Ind. Mus., vii, 297.

\section{Ascaridia Dujardin, 1845.}

Lips well developed, without "eordons." Oesophagus elubshaped, withont posterior bulb. Male with slight eandal alae and relatively large eandal papillae. Spieules equal or subequal. No aecessory piece. Uterine branehes opposed. Eggs with an internal thickening of the shell at one pole.

Hab. Small intestine of Birds and Reptiles.

Genotype: A. [Ascaris] hermaphrodita (Frölich, 1789).

Frölieh, 1789, Naturforscher, Halle, xxiv, 151; Dujardin, 1845, Histoire naturelle des Helminthes, Paris, 151, 214; Travassos, 1913, Mem. Inst. Osu. Cruz, Rio de Janeiro, v, 288 ; Lane, 1914, Ind. Journ. Med. Res., ii, 662, and 1917, iv, 756 .

On the ground of the absenee of an oesophageal bulb Travassos (1920 (?), Rev. Vet. e Zootech., Rio de Janeiro, 64) plaees this genus in a subfamily Ascaridiinae of the family Ascaridae. In our view the presence of a typieal eaudal sucker with a elitinoid border in the male necessitates its inclusion among the Heterakidae, as was originally proposed by Railliet \& Henry (1914, Proc. Internat. Zool. Congr., 677).

\section{Aspidodera Railliet \& Henry, 1912.}

Syn. Aspidocephalus Diesing, 1851, nec Motasch, 1839.

Lips with "cordons" opening in pairs at the interlabial spaees, diverging and reeurrent, the reeurrent branches anastomosing on the outer surfaces of the lips. Oesophagus, as in Heterakis and Pseudaspidodera, witlı a pharynx and a well-developed posterior pyriform bulb. Male withont eaudal alae. Spienles equal. An aceessory piece present. Uterine branches opposed. Eggs thin-shelled.

Hab. Alimentary eanal of Edentates and Marsupials.

Genotype: A. [Aspidocephalus] scoleciformis (Diesing, $1851)$.

Diesing, 1851, Systema Helminthum, ii, 208; Railliet \& Henry, 1912, Bull. Soc. Path. exot., Paris, v, 257; 1913, Bull. Mus. Hist. Nat., Paris, 93.

\section{Paraspidodera Travassos, 1914.}

Lips large and well developed, resembling those of Ascaris, without "eordons." Oesophagus with a pharynx and a 
posterior bulb. Male without caudal alae. Spicules șubequal. An accessory piece present.

Hab. Colon and caecum of Rodents.

Genotype : P. [Ascaris] uncinata (Rudolphi, 1819).

Rudolphi, 1819, Entozoorum Synopsis, 661; Travassos, 1914, Mem. Inst. Osw. Cruz, Rio de Janeiro, vi, 137; Hall, 1916, Proc. U.S. Nat. Mus., l, 44, 49.

\section{Strongyluris Müller, 1894 .}

Lateral fields conspicuous, composed of a single row of large cells. Lips well developed, without "cordons," but expanded in front and at the sides into a cuticular flange. Oesophagus with relatively long pharynx, the lumen of which forms a ventral "kink" at its posterior end, and with a welldeveloped posterior bulb. Tail of male obliquely truncate ventrally, and with a short terminal spike. Well-developed alae supported by stout pedunculate papillae, giving the appearance of a bursa. Spicules relatively long, equal. No accessory piece. Uterine branches parallel. Segmentation may begin before oviposition.

Hab. Alimentary canal of Lizards and Chameleons.

Genotype: S. brevicaudata Müller, 1894.

Müller, 1894, Arch.f. Naturg., 1x, 113, 116.

\section{Spinicauda Travassos, 1920 .}

Syn. Sonsinia Baylis \& Daubney, 1922.

Lateral fields conspicuous, composed of single row of large cells. Lips subtriangular, expanded anteriorly and laterally as in Strongyluris, without "cordons." Oesophagus with a short pharynx and a posterior bulb. Tail of male long, straight and tapering, without alae. Papillae small and sessile. Spicules short, subequal. An accessory piece present. Uterine branches parallel.

Hab. Alimentary canal of Lizards and Chameleons. 1819).

Genotype: S. [Ascaris] spinicauda (Olfers, in Rudolphi,

Olfers, in Rudolphi, 1819, Entozoorum Synopsis, 40, 27:; Travassos, 1920 (?), Rev. Vet. e Zootech., Rio de Janeiro, 64; 1920, Mem. Inst. Osw. Cruz, Rio de Janeiro, xii, 44; Baylis \& Daubncy, 1922, Mem. Ind. Mus., vii, 297; Baylis, 1923, Parasitol., xv, 12.

Spinicauda icosiensis Seurat, 1917, appears to occupy a position intermediate between this genus and Strongyluris, because the tail of the male is obliquely truncate ventrally but has an elongate terminal cone. 


\section{Africana Travassos, 1920.}

Lips well developed, subglobular, without "cordons," expanded anteriorly and laterally into cuticular flanges. Oesophagus with a pharyux and a bulb. Tail of male straight and eonical. Caudal alae somewhat reduced, barely extending beyond the cloaca. Papillae sessile and mostly small. Spicules long and slender, equal or unequal. No accessory piece. Uterine branches apparently opposed. Eggs with thick shell.

Hab. Alimentary canal of Lizards and Chameleons.

Genotype: A. [Heterakis] africana (Gendre, 1909).

Gendre, 1909, Proc. Verb. Soc. Linn., Bordeaux, lxiii, 33 ; Travassos, 1920, Mem. Inst. Osw. Cruz, Rio de Janeiro, xii, 48.

\section{Subfam. 2. SUBULURINAE Travassos, 1914.}

Lips much reduced or absent. A cylindrical bueeal eapsule present, except in Cissophyllus, in which the lips are well developed. Oesophagus without pharyngeal portion (except in Cissophyllus) and with a posterior bulb. Preanal sucker antero-posteriorly elongated, fusiform or elliptical. Vulva ustally about the middle of the body, oceasionally posterior. Eggs usually containing embryos when laid.

The genus Cissophyllus is exceptional in so many particulars that it appears to oceupy a position intermediate between this subfamily and the Heterakinae. Maupasina is exceptional in that the preanal sucker appears to have been replaced by a vesicular swelling, and in the position of the vulva.

\section{Subulura Molin, 1860.}

\section{Syn. Allodapa Diesing, IS61.}

Lips rarely apparent. Mouth usually oval or hexagonal, with its long axis dorso-ventral. Buccal capsule with three teeth at its base. Lateral cervical alae frequently present. Tail of male with more or less well-developed alae. Caudal papillae sessile, eleven pairs or fewer. Spicules two, equal, slender, alate. An accessory piece present. Preanal sucker fusiform. Eggs subglobular, usually containing embryos when laid.

Hab. Alimentary canal of Birds, Mammals and (?) Fishes.

Genotype: S. acutissima Molin, 1860.

Molin, 1860, Sitz. k. Akad. Wiss., Wien, xl, 332; Diesing, 1861, Sitz. k. Alad. Wiss., Wien, xlii, 614, 644; Seurat, 1914, Bull. Soc. Hist. Nat. Afrique Nord, Alger, vi. 195; Barreto, 1919, Mem. Inst. Osw. Cruz, Rio de Janeiro, xi, 12.

2. Oxynema v. Linstow, 1899.

Lips not apparent. Mouth circular. Buccal capsule with three teeth at its base. 'Tail of male with slight alae. Caudal 
papillae sessile, ten or eleven pairs. A single spicule and an accessory piece present. Preanal sucker fusiform. Eggs subglobular, containing embryos when laid.

Hab. Intestine and caccum of Carnivores and Rodents.

Genotype: O. [Heterakis] crassispiculum (Sonsino, 1889) (=O. rectum $\nabla$. Linstow, 1899).

Sonsino, 1859, Atti. Soc. Tosc. Sci. Nat., Pisa, x, 227 ; v. Linstow, 1899, Mitt. Zool. Mus., Berlin, i, 19.

Barreto (1919, Mem. Inst. Osw. Cruz, Rio de Janeiro, xi, 51) has revived the genus Oxynema, which had been regarded by some authors as a synonym of Allodapa, to include the two species crassispiculum and boueti (Gendre, 1911), in which only a single spicule is present.

\section{Heteroxynema Hall, 1916.}

Lips apparent. Teeth feebly, if at all, developed at the base of the buccal capsule. Cervical alae present. Male without spicules or accessory piece. Caudal papillae eleven pairs, mostly near the cloaca. Preanal sucker fusiform, bordered, at the sides only, by a delicate cuticular membrane ornamented with tranverse rows of trabeculae. Eggs bluntly pointed, rather like those of Oxyuridae.

Hab. Caecum and large intestine of a Rodent (one species known).

Genotype : H. cucullatum Hall, 1916.

Hall, 1916, Proc. U. S. Nat. Mus., 1, 56.

\section{Numidica Barreto, 1919.}

Lips indistinct. Buccal capsule with thick walls, divided into an anterior and a posterior chamber, the latter containing three teeth at its base. Lateral alae absent. Male with unequal spicules, the right larger and well-chitinized, the left very slightly so. An accessory piece present. Caudal papillae pedunculate, ten pairs (four preanal, six postanal). Preanal sucker elliptical, bordered by a rim covered with small cuticular trabeculae. Eggs rounded, containing embryos when laid.

Hab. Intestine of Carnivores (one species known).

Genotype : N. [Allodapa] numidica (Seurat, 1915).

Seurat, 1915, Compt. rend. Soc. Biol., Paris, lxxviii, 122 ; Barreto, 1919, Mem. Inst. Osw. Cruz, Rio de Janeiro, xi, 57.

According to Seurat, there are two indistinct lateral lips, each bearing three papillae.

5. Maupasina Seurat, 1913.

Syn. Maupasiella Seurat, 1913.

Lips not distinct. Mouth surrounded by three pairs of 
prominent setiform papillae. Bneeal capsule divided into an anterior and a posterior ehamber, the latter occupied by three trieuspid teeth. Tail of male obliquely truneate, with broad eaudal alae. Caudal papillae peduneulate, ten pairs. Spienles two, equal. An aeeessory piece present. No preanal sueker, but a vesicular swelling present in front of cloaea. Vulva immediately in front of anus, preeeded by a sudden eonstrietion of the body. Uterine branches parallel. Eggs containing embryos when laid.

Hab. Alimentary canal of an insectivorons Mammal (one speeies know'n).

Genotype: M. [Maupasiella] weissi (Seurat, 1913).

Seurat, 1913, Bull. Soc. Hist. Nat. Afrique Nord, Alger, iv, 127 ; 1913 , Compt.rend. Soc. Biol., Paris, lxxv, 326.

Seurat (1917, Compt. rend. Soc. Biol., Paris, lxxx, 350) states that there are two indistinet lateral lips, each bearing laterally a pair of papillae and anteriorly a papilliform projection.

\section{Fam. 3. KATHLANIIDAE Travassos, 1918, emend.}

Parasitic forms. Meromyarian. Three well-developed lips, entire or subdivided. Oesophagus preeeded either by a ehitinoid bnecal eapsule or by a museular pharynx with a eutieular lining, unarmed or containing tooth-like struetures. Oesophagus with a prebulbar swelling and a large posterior muscular bulb, separated from the former by a rather narrow neek, the two swellings and the neek together giving the appearance of a single dumbbell-shaped or Hlask-shaped bulb. Tail of male without alae. The ventral museles in the preanal region of the male frequently aggregated to form one or more fusiform sueker-like organs withont a chitinoid border. Reproductive organs moderately highly-developed. Spicnles two, equal or subequal, usually falciform and broadly alate. An aceessory pieee usually present. Vulva at about the middle of the body or somewhat behind it. Uterine branches opposed. Oviparons or viviparous.

Aceording to Travassos, the musculature of Cruzia is "ineompletely polymyarian."

\section{Kathlania Lane, 1914.}

Syn. Pseudoheterakis Travassos, 1917; Oxysoma Sehneider, $1866, e \cdot p$.

Head separated from body by a slight constrietion. Lateral alae present. Each lip subdivided into a large main lobe and four smaller aceessory lobes, two on each side of the main lobe. In the mid-ventral position there is an additional 
unpaired lobe or interlabium. The two lateral and four submedian cephalic papillae are situated on certain of the accessory lobes, while each main lobe has a pair of very small papillae on its inner surface. A buccal capsule present, triangular in section and with three tooth-like structures at its entrance. Tail of male ending in a long spike. A muscular preanal sucker-like organ present. Caudal papillae sessile, twenty-three in number (six pairs and one unpaired papilla preanal, five pairs postanal). Spicules relatively short, subequal, broadly alate. A large $Y$-shaped accessory piece present. Vulva behind the middle of the body. The anterior uterine branch turns to run posteriorly parallel with the other. Eggs with thin, finely striated shell, containing embryos when laid.

Hab. Alimentary canal of marine Turtle (one species known).

Genotype : $K$. [Ascaris] leptura (Rudolphi, 1819) $(=K$. kathlena Lane, 1914).

Rudolphi, 1819, Entozoorum Synopsis, 48; Lane, 1914, Ind. Journ. Med. Res., Calcutta, ii, 664; Travassos, 1917, Brazil. Med., Rio de Janeiro, No. 12; 1918, Rev. Soc. Brazil. Sci., ii, 84.

\section{Tonaudia Travassos, 1918.}

Head separated from body by a well-marked constriction, the posterior margin of the head forming a sharp angle. Lateral alae present. Lips and buccal capsule as in Kathlania. Tail of male ends in a long spike, which is directed dorsally. A muscular preanal sucker-like organ present. Eight pairs of caudal papillae and an umpaired preanal papilla present. Spicules extremely long and slender, reaching anteriorly to the middle of the oesophagus when not extruded, and with narrow alae. A $Y$-shaped accessory piece present, not strongly chitinized. Vulva slightly behind the middle of the body. Vagina very long and coiled. Female organs in other respects as in Kathlania.

Hab. Alimentary canal of marine Turtle (one species known). Genotype : T. [Kathlania] tonaudia (Lane, 1914).

Lane, 1914, Ind. Journ. Med. Res., Calcutta, ii, 668; Travassos, 1919, Rev. Soc. Brazil. Sci., 84.

\section{Spironoura Leidy, 1856.}

Syn. Spirura Diesing, 1861, nec Blanchard, 1849; Falcaustra Lane, 1915; Florencioia Travassos, 1919.

Head frequently wider than neck, occasionally not distinct. Lateral fields wide. Lateral alae absent. Lips entire, each bearing two outer and two immer papillae. Oral cavity supported by a continuous cuticular ring. Pharynx muscular,

SYN. NEM. 
with narrow lumen. Tail in both sexes tapering and pointed. Male with ten or more pairs of eandal papillae (of which three pairs are preanal) and an unpaired preanal papilla. Prcanal calldal muscles of male sometimes aggregated into one or several fan-shaped sucker-like organs. Spicules equal, relatively short, sickle-shaped, usually broadly alate. An accessory piece usually present, sometimes imperfectly chitinized or absent. Vulva towards, the posterior third of the body. Eggs usually large, thick-shelled, oval, laid at various stages of development, according to species.

Hab. Intestine of Tortoises, Batraehians and fresh-water Fishes.

Genotype: S. gracile Leidy, 1856.

Leidy, 1856, Proc. Acad. Nat. Sci., Philadelphia, viii, 52; Lane, 1915, Ind. Journ. Med. Res., Calcutta, iii, 109 ; Baylis, 1920, Ann. Mag. Nat. Hist., London, vi, 414; Travassos, 1920, Arch. Esc. Sup. Agric. e Med. Vet., Nictheroy, iv, 21; Baylis \& Daubney, 1922, Mem. Ind. Mus., Calcutta, vii, 309; Boulenger, 1923, Parasitol., xv, 53; Chapin, 1924, Journ. Parasitol., x, 212.

\section{Zanclophorus Baylis \& Daubncy, 1922.}

Head somewhat narrower than neck, surrounded by a slight cuticular collar at its base. Lips large, entire, anteriorly flattened, each carrying a pair of rather prominent papillae and bordered internally by euticular fringes. Oral cavity with three separate double horseshoe-shaped chitinoid supports at its angles. Pharynx with wide lumen, lined with thickened cuticle. A single, well-developed, museular, preanal sucker present in the male. Spicules as in Spironoura, but relatively much longer. A large, but incompletely chitinized, accessory piece present. Female organs as in Spironoura.

Hab. Stomach and intestine of land Tortoises.

Genotype: Z. annandalei Baylis \& Daubney, 1922.

Baylis \& Daubney, 1922, Mem. Ind. Mus., Caleutta, vii, 310.

5. Cruzia Travassos, 1917.

Syn. Oxysoma Schneider, 1866, e. p.

Head not distinet. Lateral fields broad. Lips well developed, subtriangular. Pharynx three-sided, with narrow lumen, strongly chitinized, and containing three longitudinal series of anteriorly-directed tecth. At its base there are also three large, blunt, tooth-like structures. Intestine with an anterior eaecum. Tail of male conical. Nine pairs of caudal papillae present (four preanal, five postanal). Ventral surface of preanal region rugose. Caudal museles well developed but not aggregated into a sueker-like lorgan. 
Spicules subequal, alate. A large subtriangular accessory piece present. Tail of female tapering. Vulva slightly in front of the middle of the body, not prominent. Eggs relatively large, with thick, rugose shell, containing embryos when laid.

Hab. Caecum and large intestine of Opossums (one species known).

Genotype: C. [Ascaris] tentaculata (Rudolphi, 1819).

Rudolphi, 1819, Entozoorum Synopsis, 658 ; Travassos, 1917 , Brazil. Med., Rio de Janeiro, xxxi, N. 12;1922, Mem. Inst. Osw. Cruz, Rio de Janeiro, xiv, N. 1.

This genus appears to fall naturally into the family Kathlaniidae, the characters in which it differs from the preceding genera being so slight that, in our view, they do not justify the ercetion of a distinct family Cruzidac, as is proposed by Travassos. Nor can we follow Ortlepp (1924, Journ. Helminthol., ii, 17), who proposes to erect for Cruzia a new subfamily, Cruzinac, of the family Heterakidae.

\section{Cissophyllus Railliet \& Henry, 1912.}

Lips complex; the dorsal lip trident-shaped, the ventrolateral lips furnished with groups of lancet-like teeth. Buccal capsule apparently absent. Oesophagus with a pharyux and a posterior bulb. Tail of male without alae. Candal papillae small, sessile. Spicules subequal. An accessory piece present. Preanal sucker fusiform. Vulva in posterior third of body. Uterine branches parallel. Eggs segmenting when laid.

Hab. Intestine of Chelonia.

Genotype : C. laverani Railliet \& Henry, 1912.

Railliet \& Henry, 1912, Bull. Soc. Path. exot., Paris, v, 253.

\section{Probstmayria Ransom, 1907.}

Head truncate. Lips bilobed, the dorsal lip having two papillae with long peduncles, the ventro-lateral lips each one such papilla. Pharynx tubular, composed of a small anterior portion without muscles and a longer, muscular, posterior portion. Caudal end of male without sucker-like organ. Several pairs of small postanal papillae present. Spicules short, subequal. Tail in both sexes long and tapering. Vulva about the middle of the body. Viviparous (eggs few and large, hatching in uterus).

Hab. Colon of Equidac (one species known).

Genotype: P. [Oxyuris] vivipara (Probstmayr, 1865).

Probstmayr, 1865, Wochenschr. f. Thierh. u. Viehz., Augsburg, ix, 178; Ransom, 1907, Trans. Amer. Microsc. Soc., xxvii, 33 ; Baylis, 1923, Parasitol., xv, 36. 
8. Amblyonema v. Linstow, 1898.

Three low eonical lips present. Slight lateral alae, rounded posteriorly. At the base of the oral eavity three trilobed teeth present. Oesophagus long, slender, with a small prebulbar swelling and a large posterior bulb. Tail rounded, with a short terminal spike. Male with three pairs of preanal and one pair of postanal papillae, the latter dorsally directed. Two equal, alate spicules and an aecessory piece present. Vulva in the posterior half of the body. Eggs large, thiek-shelled.

Hab. Intestine of Australian Lung-fish (Ceratodus) (one speeies known).

Genotype: A. terdentatum v. Linstow, 1898.

v. Linstow, 1898, Denkschr. Med. Nat. Ges., Jena, viii, 470.

According to Travassos (1920 (?)) this genus falls into the subfamily Oxysomatinae of the family Oxyuridae, and is placed by him near Probstmayria, which in our view belongs to the Kathlaniidae. The characters mentioned by v. Linstow for Amblyonema seem to us to indieate eloser relationship with the latter family than with the Oxyuridae.

\section{Spectatus Travassos, 1923.}

Head somewhat wider than neck. Lips well developed, bilobed. Prebulbar swelling of oesophagus mueh reduced. Tail of male short and conieal. A muscular preanal sueker-like organ present. Candal papillae sessile, twenty-two in number (five pairs preanal). Spicules short, faleiform, equal and alate. Aceessory piece $\mathbf{V}$-shaped. Tail of female very short. Vulva in the middle of the body. Vagina long.

Hab. Intestine of a Fish (one speeies known).

Genotype: S. spectatus Travassos, 1923.

Travassos, 1923, Folh. Med., Rio de Janeiro, vi (15 Feb.), 29.

\section{Fam. 4. OXYASCARIDAE Travassos, 1920.}

Parasitie forms. Meromyarian. Males very mueh smaller than females. Lips greatly redneed. No bueeal eapsule. Oesophagus with a pyriform ventrieulus. Intestine ends in a voluminous pyriform rectum whieh is highly ehitinized. Spieules equal, small, poorly ehitinized. Accessory piece apparently absent. Candal alae absent. Caudal papillae few. Vulva in anterior half of body. Uteri opposed. Eggs eontaining embryos when laid.

1. Oxyascaris Travassos, 1920.

With the eharaeters of the family.

Hab. Intestine of Reptiles and Batraehians.

Genotype: O. oxyascaris Travassos, 1920. 
Fam. 5. OXYURIDAE Cobbold, 1864.

Parasitic forms. Meromyarian. Mouth with simple, usually inconspieuous lips. No buceal capsule. Oesophagus usnally with a pharynx and always with a distinet posterior bulb, containing three valves. Reproductive organs simple. Oviparous. Ovaries short, produeing relatively few large eggs. Excretory pore at about the level of the oesophageal bulb or even behind it. Caudal end of mature female always elongated and subulate. Male withont a preanal sucker, except in Hoplodontophorus.

This family appears to form a fairly homogeneous group, and we have not felt justified in retaining the families Pharyngodonidae and Isakidae of Travassos (1920 (?)). The contents of the former appear to fall naturally into the subfamily Oxyurinae, while Isakis, the sole representative of the Isakidae, may be included among the Cosmocereinae. The subfamily Syphaciinae Railliet (1916, Réc. Méd. Vét., 521) is discarded, since its genera also appear to fall into the Oxyurinac.

\section{Subfam. 1. OXYURINAE Hall, 1916.}

Mouth with three or six lips. Male with a single spicule, which may be restigial (rarely without a spieule), and usually without an aecessory piece. The caudal papillae of the male mainly in the vicinity of the eloaca.

\section{Oxyuris Rudolphi, 1803.}

Syn. Lepluris Schlotthauber, 1860.

Lips not apparent. Cuticle of head not inflated. Mouth hexagonal. One pair of lateral and two pairs of large submedian cephalic papillae present. Oesophagus relatively short, hourglass-shaped, with a short pharynx, containing numerous cuticular bristles in both sexes and three prominent teeth in the female. Its narrow middle portion passes gradually into the posterior pyriform bulb. Tail of male truncate, with alar expansions in front of and behind the eloaea, each supported by a pair of pedunculate papillae. Two pairs of smaller eaudal papillae present. A single spicule, without an aecessory piece. Tail of female extremely long. Vulva towards the anterior end of the body, but postoesophageal. The common trunk of the uterus extremely long, extending almost to the posterior end, and there dividing into two short branches which run parallel to each other in the anterior direction. Eggs elongated, flattened on one side, unsegmented when laid, with thick shell, having an opening at one pole filled by a plug which is outwardly concave. 
Hab. Large intestine of Equidae (one species known).

Genotype : O. [Ascaris] equi (Schrank, 1788).

Schrank, 1788, Verzeichniss der... Eingeweidewürmer, Hünchen, 7; Rudolphi, 1803, Arch. f. Zool. u. Zoot., Brunswick, iii, 6; Yorke \& Macfie, 1922, Trans. R. Soc. Trop. Med. Hyg., London, xr, 148.

\section{Dermatoxys Schneider, 1866.}

Lips well developed, each with a tooth projecting from its imer surface. Oesophagus honrglass-shaped, with a long, slender middle portion and a posterior bulb. Cervieal alae present. Posterior end of the male with very long welldeveloped alae, and provided on its ventral surface in the preanal region with a eurving longitudinal row of comb-like crests. Candal papillae mainly grouped around the cloaca. A single spieule, very small. Accessory piece absent. Vulva in the anterior half of the body. The common trunk of the uterus extends posteriorly to a point beyond the anus, the branches passing forward parallel to each other. Eggs with a thick shell, stippled externally, slightly flattened on one side and with an aperture near one pole, apparently elosed by a plug.

Hab. Alimentary canal of Rodents.

Genotype: D. [Ascaris] veligera (Rudolphi, 1819).

Rudolphi, 1819, Entozoorum Synopsis, 656 ; Schneider, 1866 , Monographie der Nematoden, Berlin, 123; Hall, 1916, Proc. U.S. Nat. Mus., 1, 99.

\section{Hoplodontophorus Turner, 1921.}

Mouth with three lips, not very apparent, situated in a shallow depression having twelve papillae round its edge. Oesophagus hourglass-shaped, the anterior portion representing the oesophagus proper and the posterior portion the bulb. A pharynx present. Tail of male with wide alae supported by three pairs of papillae, one large and preanal, the remaining two near the posterior end. One pair of ventral papillae at the level of the eloaca. A muscular sucker on the ventral surface in the preanal region, with an opening in its posterior border. A single spicule and an accessory piece. Tail of female long and slender, with rounded tip and small terminal spike. Vulva in the anterior third of the body, with prominent lips. Common trunk of uterus runs posteriorly almost as far as the anus. Uterine branches parallel, running anteriorly. Eggs large, elongated, flattened on one side.

Hab. Alimentary eanal of Hyrax (one species linown).

Genotype: H. [Oxyuris] flagellum (Ehrenb., in Hempr. \& Ehrenb., 1828). 
Hemprich \& Ehrenberg, 1828, Symbolae physicae, Pars Zoologica, decas prima (Mammalia); Turner, 1921, Trans. $R$. Soc. Trop. Med. Hyg., London, xv, 187; Monnig, 1924, 9th and loth Rep. Dir. Vet. Ed. and Res., Pretoria, 442.

\section{Enterobius Leach, in Baird, 1853.}

Syn. Oxyurias Stiles, 1905; Fusarella Seurat, 1916; Trypanoxyuris Vevers, 1923.

Cuticle of anterior end inflated. Lips fairly distinct. Mouth triradiate. Narrow lateral alae present. Oesophagus with a prebulbar swelling and a distinct bulb. Tail of male truncate, with alae supported in front by a pair of pedunculate preanal papillae, and behind by a pair at the extremity of the tail. Two or three pairs of sessile postanal papillae also present. A single spicule, relatively long. No accessory piece.* Vulva in the anterior half of the body. Common trunk of the uterus short. Uterine branches parallel.

Hab. Large intestine of Primates.

Genotype : E. [Ascaris] vermicularis (L., 1758).

Leach, in Baird, 1853, Cat. Entozoa Brit. Mus., 108 ; Seurat, 1916, Compt. rend. Soc. Biol., Paris, lxxviii, 67 (Fusarella); Yorke \& Macfie, 1922, Trans. R. Soc. Trop. Med. Hyg., London, xv, 148.

\section{Protozoophaga Travassos, 1923.}

Lips not apparent. Oesophagus cylindrical. A welldeveloped posterior bulb present. Tail of male alate, with two pairs of large lateral papillae and a conical terminal process. A single spicule, feebly chitinized. Accessory piece absent. Tail of female conical in the young, long and tapering, up to half the total length, in the adult. Vulva in anterior region of body. Uterine branches parallel, running anteriorly.

Hab. Alimentary canal of a Rodent (one species known).

Genotype : P. [Oxyuris] obesa (Diesing, 1851).

Diesing, 1851, Systema Helminthum, ii, 141; Travassos, 1923, Folh. Med., Rio de Janeiro, iv, 36.

* In Trypanoxyuris trypanuris Vevers (1923, Journ. Helminthol., i, 39) there is said to be an annular gubernaculum. It seems possible that this statement is founded upon a misinterpretation. An annular gubernaculum of the type shown in Vevers' figure 2, B, would apparently prevent the extrusion of the spicule. The only other character to distinguish Trypanoxyuris from Enterobius is the presence of a short tail-spike in the male, and this appears too small a character upon which to found a new genus. 
The validity of this genus appears extremely doubtful. Up to the present the genotype is not characterized sufficiently to enable its affinities with other genera to be determined.

\section{Thelandros Wedl, 1962 .}

Lips bilobed. Buccal eapsule absent. Oesophagus with a very short pharynx and a posterior bulb. Lateral fields each formed of a single row of very large cells with stellate nuclei. Lateral alae present in male in some species, sometimes extending posteriorly as far as the eloaea. Tail of male ends in a dorsal process. Caudal alae absent. Three pairs of caudal papillae present, one of which is situated on the ventral surface of the caudal process. A single spicule, sharply pointed. Aceessory piece absent. Tail of female suddenly constricted behind the anus to form a terminal spike. Vulva usually a little behind the middle of the body. Uterine branches parallel. Eggs oval, not containing embryos when lairl.

Hab. Alimentary canal of Lizards and Tortoises.

Genotype: T. alotus Wedl, 1862.

Wedl, 1862, Sitz. k. Akad. Wiss., Wien, xliv, 470; Seurat, 1917, Arch. Zool. exp. et gén., Paris, Ivi, 412.

\section{Ozolaimus Dujardin, 1845.}

Head with "two lateral lobes," diverging distally. Mouth elongated dorso-ventrally. Oesophagus long, composed of two distinet portions; the anterior short and stout, with a fusiform swelling behind; the posterior slender, ending in a distinet bulb behind. Tail of male short, finger-shaped, bluntly rounded. A single long, stout spicule present. Tail of female tapering. Vulva prominent, at about the posterior fourth of the body. Female genital organs anterior. Eggs large.

Hab. Intestine of Iguana.

Genotype: O. [Ascaris] megatyphlon (Rudolphi, 1819).

Ruclolphi, 1819, Entozoorum Synopsis, 47, 285; Dujardin, 1845, Histoire nat. des Helminthes, 145; Schneider, 1866, Monographie der Nematoden, 120; v. Linstow, 1906, Arch.f. Naturg., lxxii, i, 254 (Oxyuris cirrata).

\section{Macracis Gedoelst, 1916.}

Mouth a vertical slit with lateral raised borders. Lateral and submedian papillae present. Oesophagus very long and slender, with three anteriorly direeted valve-like eutieular folds at its entrance, and with a large posterior bulb. Tail in both sexes short and conical. Tail of male apparently without alae, truneate ventrally, and with a short, dorsoventrally flattened, dorsal appendage, bearing a pair of 
papillae near its tip. Two pairs of preanal and one pair of postanal papillac also present on the lips of the cloaca, and a truncate median postanal process. A single long, alate spiculc present. Vulva at about the posterior third of the body. Female organs confined to about the middle third of the body. Vagina long, running anteriorly, then posteriorly. Common trunk of uterus short, its branches turning forward near their origin and parallel. Ovaries reflexed.

Hab. Alimentary canal of an Ignana (one species knowu).

Genotype: M. [Oxyuris] monhystera (v. Linstow, 1902).

v. Linstow, 1902, Centralbl. f. Bakt., xxxi, 30; Gedoelst, 1916, Rev. Zool. Afric., 77; Rauther, 1918, Zool. Jahrb., Anat., xl, 441.

Gedoelst (1916) originally referred this genus to the Atractinae on the ground of $\mathrm{v}$. Linstow's statement that the female organs were unpaired. Following, however, Rauther's redescription of $O$. monhystera, this view was abandoned.

\section{Pharyngodon Diesing, 1861.}

Cuticle rather thick, with relatively well-marked transverse striations. Lips not apparent. No buccal cavity. Oesophagus with a posterior bulb. In the male a single pair of lateral alae present. In the female two parallel alae extend along each lateral field. Lateral fields composed of a single row of large cells with rounded nuclei. Tail of male suddenly constricted at the level of the cloaca, and continued as a long, dorsally-directed, conical process, the anterior portion of which bears short and broad lateral alae. One pair of sessile preanal papillae and two pairs of pedunculate postanal papillae present. Of the latter, the posterior pair is near the posterior limit of the alae. A single spicule, sharply pointed. Accessory piece absent. Tail of female rather suddenly constricted behind the anus to form a terminal spike, sometimes bearing spines. Vulva postoesophageal. Uterine branches narrow and parallel. Eggs very long and narrow, with an operculum at each end.

Hab. Rectum of Lizards.

Genotype : P. [Oxyuris] spinicauda (Dujardin, 1845).

Dujardin, 1845, Histoire naturelle des Helminthes, Paris, 143 ; Diesing, 1861, Sitz. k. Akad.Wiss., Wien, xlii, 642; Seurat, 1917, Arch. Zool. exp. et gén., Paris, lvi, 404.

10. Tachygonetria Wedl, 1862.

Syn. Paracis Railliet \& Henry, 1916; Mehdiella Seurat, 1918.

Lips not apparent. Oesophagus usually long, and with a posterior bulb. Lateral alae absent. Lateral fields dark- 
coloured, broad, consisting of a single row of large cells. Tail of male suddenly eonstrieted at the level of the cloaca and continued as a dorsally-directed conical process, with or withont a terminal spike. Five pairs of caudal papillae present, of which three pairs are grouped about the cloaca (one pair preanal, one at the level of the cloaca, one postanal), the remaining two pairs being lateral, one at the posterior end of the alae and the other midway between these and the eloaca. Posterior lip of eloaca swollen into a conical process. A single spieule, short, with a straight or barbed point. An aecessory pieee present, shaped like a very open $V$. Vulva usually behind the middle of the body. Common trunk of uterus short. Uterine branches parallel. Eggs large, few in number, segmenting when laid, oceasionally containing embryos.

Hab. Caecum of herbivorous Reptiles (Tortoises and Uromastix).

Genotype: T. vivipara Wedl, 1862.

Wedl, 1862, Sitz. k. Akad. Wiss., Wien, xliv, 471, 482; Seurat, 1912, Compt. rend. Soc. Biol., Paris, lxxiii, 223; 1918, Arch. Inst. Past. Tunis, x, 247.

According to Seurat $(1912,1913,1917), T$. vivipara has two types of female, one of which is oviparous and the other viviparous. In the latter the larvae reach the eneysted or infeetive stage within the uterus. Seurat has proposed the genus Mehdiella, with microstoma (Drasche) as its genotype. The differenees mentioned, however, do not appear to be suffieient to warrant a generic distinetion between Mehdiella and Tachygonetria.

\section{Aorurus Leidy, 1849.}

Syn. Streptostoma Leidy, 1849.

Cuticle coarsely striated. Mouth large, eireular, without apparent lips. Head followed by a slightly projecting eutieular collar. Oesophagus with a large pyriform prebulbar swelling and a distinet posterior muscular bulb joined to it by a slender neek. 'The prebulbar swelling is almost equal in size to the museular bulb. Tail of male obliquely truncate ventrally, and with a subulate terminal process dorsally, bearing a pair of papillae near its base. Two pairs of preanal papillae and a median postanal conical process also present. A single spicule present. Apparently no aecessory pieee. Tail of female extremely long and subulate. Vulva in anterior half of body, behind oesophageal bulb. Uterine branches and ovaries parallel. Eggs flattened on one side.

Hab. Intestine of Myriopoda (Julus) and Orthoptera (Blatta).

Genotype: A. [Streptostoma] agilis (Leidy, 1849). 
Leidy, 1849, Proc. Acad. Nat. Sci., Philadelphia, iv, 230 and 1850, v, 100; 1853, Smithsonian Contr. Knowl., Washington, v, 45; Hammerschmidt, 1838, Isis (Oken), Lcipzig, 354 (Oxyuris diesingi); 1847, Naturw. Abhandl., Wien, i, 284 (Oxyuris blattae-orientalis, e. p.); Galeb, 1878, Arch. Zool. exp. el gén., Paris, vii, 293 (Oxyuris diesingi, not O. blattae).

Aorurus, as originally described by Leidy, consisted of the two subgenera Streptostoma and Thelastoma. These he raised later, no doubt rightly, to the rank of genera. In these circumstances, Streptostoma becomes a synonym of Aorurus.

12. Thelastoma Leidy, 1849 .

Cuticle coarsely striated. Lateral alae present. Mouth small, without apparent lips. A short pharynx apparently present. Oesophagus proper club-shaped, followed by a distinct pyriform bulb. Intestine may be provided near its origin with a posteriorly-directed caecum. Male unknown.* Tail of female long, subulate. Vulva in the posterior half of the body. Uterine branches and ovaries apparently opposed. Eggs flattened on one side.

Hab. Intestine of Myriopoda, Coleoptera and Orthoptera.

Genotype : T. attenuatum Leidy, 1849.

Hammerschmidt, 1847, Naturw. Abhandl., Wien, i, 284 (Oxyuris blattae-orientalis, e. p.); Leidy, 1849, Proc. Acad. Nat. Sci., Philadelphia, iv, 231; 1853, Smithsonian Contr. Knowl., Washington, v, 46; Galeb, 1878, Arch. Zool. exp. et gén., Paris, vi, 292 (Oxyuris blattae).

Although the characters given by Leidy and others are sufficient to distinguish Thelastoma from Aorurus, they cannot be said to furnish a satisfactory diagnosis, in the absence of a fuller description of the genotype.

\section{Pseudonymus Diesing, 1857.} 1878.

Syn. Ptychocephalus Diesing, 1861; Helicothrix Galeb,

Cuticle of neck with a series of annular swellings of different sizes. Mouth with six lips. Oesophagus club-shaped, containing six longitudinal chitinoid rodlets, and with a distinct pyriform posterior bulb. Tail of male rounded, with a truncate appendage bearing a ventrally-curved terminal spike. One pair of postanal and two pairs and one median preanal

* Leidy (1S53), in his definition of the genus, states that there is a single spicule in the male. No males appear to have been described for any of the species assigned to this genus, although Galeb (1S7S) states that in Oxyuris blattae ( $=T$. appendiculatum Leidy) the male is without the intestinal caecum possessed by the female. It seems likely that the form in question belonged to a different species. 
papillae present. Spicule single. Tail of female very long. Vulva at about posterior third of body. Female genital tubes paired, opposed. Eggs regularly oval, containing embryos when laid and with spiral filaments wound round the shells.

Hab. Intestine of aquatic Beetles.

Genotype: P. [Oxyuris] spirotheca (v. Györy, 1856).

v. Györy, 1856, Sitz. K. Akad. Wiss., Wien, xxi, 327; Diesing, 1857, Denkschr. l. Akad. Wiss., Wien, xiii, 10; 1861, Sitz. k. Aliad. Wiss., Wien, xlii, 614, 637; Railliet \& Henry, 1916, Compt. rend. Soc. Biol., Paris, lxxix, 114.

\section{Passalurus Dujardin, 1845.}

Lips not apparent. Pharynx contains three denticles. Oesophagus with a prebulbar swelling and a distinct bulb. Tail of male ends in a long spike. Cankal alae extend posteriorly to the origin of the spike, and are supported at this level by a pair of pedunculate papillae. In adaition to these there is a pair of small sessile papillae behind the cloaca, and three pairs of large sessile papillae at the level of the cloaca. A single relatively short spicule. No accessory piece. Tail of female marked externally in its distal portion with prominent annular thickenings. Vulva anterior, postoesophageal, sometimes on a short vaginal outgrowth. Common trunk of uterus long. Uterine branches parallel. There is in the female a long filament lying freely in the body-cavity, extending from in front of the vulva to the region of the anus.

Hab. Caecum and large intestine of Hares and Rabbits (one species known).

Genotype: P. [Oxyuris] ambiguus (Rudolphi, 1819).

Rudolphi, 1819, Entozoorum Synopsis, 19, 229); Dujardin, 1845, Histoire nat. des Helminthes, Paris, 230, 231; Seurat, 1916, Compt. rend. Soc. Biol., Paris, lxxviii, 67; Hall, 1916, Proc. U.S. Nat. Mus., I, 68.

\section{Wellcomia Sambon, 1907.}

Lips large and broad. Interlabia present, direeted inwardly. Oesophagus with a prebulbar swelling and a distinet posterior bulb. Cervical alae may be present or absent. Intestine shows at least one anterior and one posterior dilatation, but the characters of these are not eonstant. Tail of male slightly alate, with one pair of large postanal papillae, and a pair at the level of the cloaca. A single spicule and an accessory piece present. Behind the postanal papillae the tail diminishes to a slender filament. Tail of female conical and marked externally with a spiral thickening. Vulva in anterior half of body, at the end of a long tubular raginal outgrowth.

Hab. Alimentary canal of Rodents.

Genotype: W. mitchelli Sambon, 1907. 
Sambon, 1907, Abstr. Proc. Zool. Soc., London, March 26, 15; 1907, Proc. Zool. Soc., London, 282; Hall, 1916, Proc. U.S. Nat. Mus., 1, 70; Baylis, 1922, Ann. Mag. Nat. Hist., (9) ix, 494.

\section{Syphacia Seurat, 1916.}

Lips distinct. Buccal capsule absent. Oesophagus with a short pharynx, a prebulbar swelling and a distinct postcrior bulb. Tail of male ends in a long spike. Caudal alae terminate posteriorly at the origin of the tail-spike. Two pairs of sessile preanal papillae present, one of which is situated on the lip of the cloaca. The eaudal alae are supported behind by a pair of large pedunculate postanal papillae, and contain a smaller pair at about the middle. A single relatively long spicule and an accessory piece present. Vulva in anterior region, but postoesophageal. Common trunk of uterus relatively long. Uterine branches parallel, not extending posteriorly as far as the anus.

Hab. Caecum and large intestine of Rodents.

Genotype : S. [Ascaris] obvelata (Rudolphi, 1802.)

Rudolphi, 1802, Arch. f. Zool. u. Zoot., Brunswick, ii, 18; Senrat, 1916, Compt. rend. Soc. Biol., Paris, lxxviii, 64; Hall, 1916, Proc. U.S. Nat. Mus., 1, 81.

\section{Haplacis Railliet \& Henry, 1916.}

Head rounded, with three lips and one pair of papillae. Oesophagus proper short and stout, somewhat hourglassshaped, followed by a distinct spherieal bulb. Tail of male tapering, apparently without alae. Three pairs of preanal papillae present. A single large, stout, pointed spicule present. Accessory piece absent. Tail of female tapering. Vulva towards the middle of the body, or somewhat behind it. Vagina very short. Uterine branches opposed. Eggs large, oval, segmenting when laid.

Hab. Intestine of Myriopoda.

Genotype : H. [Isacis] silvestrii (Parona, 1896).

Parona, 1896, Atti Soc. Ligust. Sci. Nat., Genova, vii, 111 ; Railliet \& Henry, 1916, Compt. rend. Soc. Biol., Paris, lxxix, 114.

Beyond the fact that this genus is placed by Railliet \& Henry among forms with a single spieule and withont an accessory piece, and in which the vulva is situated towards the middle or in the posterior half of the body, no eharaeterization of it exists. We are unable to extract from the specific deseription of the genotype any well-marked charaeter's differentiating it from other Oxyurinae. 
Subfam. 2. COSMOCERCINAE Railliet, 1916.

Lips apparent or obscure. Male with two equal or subequal spicules and usually an accessory piece (absent in Isakis and Odontogeton).

\section{Cosmocerca Diesing, 1861 .}

Syn. Nematoxys Schneider, 1866, e.p.; Ananconus Railliet \& Henry, 1916.

Lips not apparent. Oesophagus with a small pharynx, a very slight prebulbar swelling and a posterior bulb. Welldeveloped lateral alae present, extending posteriorly a little behind the anus in the female. Tail of male with fine terminal spike. Numerous small preanal and postanal papillae present, with slender peduncles. On the ventral surface of the preanal region in the male there are two longitudinal rows of comblike crests. Spicules short, equal. A strongly-chitinized accessory piece present, sometimes larger than the spicules. Vulva at about the middle of the body. Uterine branehes apparently opposed.

Hab. Intestine and lungs (?) of Batrachians.

Genotype: C.trispinosa Railliet \& Henry, 1916 (= Oxyuris ornata of Walter, 1856, nec Duj., 1845).

Walter, 1856, Zeitschr. f. wiss. Zool., Leipzig, viii, 163 ; Railliet \& Henry, 1916, Compt. rend. Soc. Biol., Paris, lxxix, 247.

2. Aplectana Railliet \& Henry, 1916.

Syn. Nematoxys Schneider, 1866, e.p.; Aplecta Railliet \& Henry, 1916.

Lips fairly distinct. Buccal capsule absent. Oesopliagus with a very short pharynx and a posterior bulb, separated from it by a constriction. Lateral alae present, extending from near the anterior end to a little behind the anus. Tail of male pointed, with numerous sessile postanal papillae. Spicules equal, short and slender. A large oblong accessory piece present. Vulva slightly in front of the middle of the body. Uterine branches apparently opposed. Embryos hatch in ulero.

Hab. Alimentary canal of Amphibians.

Genotype: A. [Ascaris] acuminata (Schrank, 1788) (= Nematoxys commutatus of Schneider, 1866, nec Cosmocerca commutata Diesing, 1861).

Dujardin, 1845, Histoire naturelle des Helminthes, Paris, 227; Schneider, 1866, Monographie der Nematoden, Berlin, 113; v. Linstow, 1909, in Braner, Süssuasserfauna Deutschlands, Heft 15, 58; Railliet \& Henry, 1916, Compt. rend. Soc. Biol., Paris, lxxix, 248; 1916, Réc. Méd. Vét., Paris, 426. 
The absence of "combs" on the ventral surface of the male, as is indicated by Railliet \& Henry, is the only salient character to distinguish this genus from Cosmocerca.

\section{Oxysomatium Railliet \& Henry, 1913.}

Syn. Oxysoma Schneider, 1866, e.p.

Lips small, sometimes not apparent. Oesophagus with a posterior bulb. 'Tail of male pointed, with from three to twelve pairs of preanal and up to six pairs of postanal papillae. Spicules equal, relatively long. A small, canoe-shaped accessory piece present. Vulva in posterior half of body. Eggs containing embryos when laid.

Hab. Alimentary canal of Amplibians and Reptiles.

Genotype : O. longespiculum Railliet \& Henry, 1916 (= Oxysoma brevicaudatum of Schneider, 1866, nec Fusaria brevicaudata Zeder, 1803).

Railliet \& Henry, 1916, Compt. rend. Soc. Biol., Paris, lxxix, 113, 247; Skrjabin, 1916, Sci. Res. Zool. Exp. Brit. E. Africa (Dogiel \& Sokolow), 1914, i (4), 140.

\section{Syphaciella Monnig, 1923.}

Cuticle of head inflated. Cervical alae present. Lips distinct. Buccal capsule absent. Oesophagus with a prebulbar swelling and a distinct posterior bulb. Tail of male ends in a spike. Wide caudal alae extend posteriorly as far as the origin of the tail-spike. Two pairs of preanal papillae; two pairs and one unpaired postanal papillae present. All the papillae are in the cloacal region. Spicules subequal. An accessory piece present. Vulva anterior, postoesophageal, surromnded by a prominent cuticular swelling. Common trunk of uterus extends posteriorly almost to the level of the anus. Uterine branches parallel.

Hab. Alimentary canal of Birds.

Genotype : S. capensis Monnig, 1923.

Monnig, 1923, Trans. R. Soc. S. Africa, xi, 108.

\section{Carnoya Gilson, 1898.}

Lips distinct, semicircular. Cuticle annulated, the anterior twelve to fifteen rings of the female each armed with fourteen spines. Male with one or two circlets of small spines on the eleventh and twelfth rings. Pharynx long, with wider anterior chamber containing three sharp teeth. Oesophagus slender, cylindrical, with a large oval muscular bulb anteriorly, containing six paired rods, and a pyriform posterior bulb containing three striated valves. Spicules apparently partly fused. An accessory piece present. Vulva in front of middle 
of body, between twenty-fifth and twenty-ninth rings. Common trumk of uterus rather short, running posteriorly. Uterine branches parallel, ruming anteriorly. Oviparous. Eggs oval, with rather thin shell.

Hab. Intestine of a Myriopod (one species known).

Genotype: C. vitiensis Gilson, 1898.

Gilson, 1898, La Cellule, xiv, 360.

\section{Isakis Lespès, 1850.}

Syn. Rhigonema Cobb, 1898.

Mouth with three low lips, laving dentieulate inner edges. Oesophagus short, with a prebulbar swelling and a spherical posterior bulb. Tail eonieally pointed. Male without caudal alae. Several pairs of preanal and postanal papillae present. Spicules equal. No aecessory piece. Vulva near middle of body. Female genital tube apparently single. Ovary reflexed. Oviparous.

Hab. Intestine of Inseets, Myriopods and (?) Molluses.

In the genotype the young are parasitie in Termites, the adults free-living.

Genotype : I. migrans Lespès, 1856.

Lespès, Ann. Sci. nat., Paris, Zool., v, 335; Cobb, 1898, Agric. Gaz. N.S.W., Sydney, ix, 311; Railliet \& Henry, 1916, Compt. rend. Soc. Bicl., Paris, lxxix, 114.

\section{Odontogeton Allgén, 1921.}

Mouth opening in a slight depression. Head with a cuticular eap which "partly forms the teeth of the mouth and partly an outer ring of strongly-developed and backwardlydirected hooks." Oesophagus with a posterior muscular bulb. Tail of male with three pairs of postanal and one pair of preanal papillae. Spienles equal. Vulva a little behind the middle of the body. Uterine branches opposed. Ovaries reflexed.

Hab. Mouth of Wart-hog (one speeies known).

Genotype: O. phacochoeri Allgén, 1921.

Allgén, 1921, Zool. Anz., liii, 84.

\section{Fam. 6. ATRACTIDAE Travassos, 1920 (?).}

Parasitie forms. Lips three or six, sometimes not apparent. Pharynx usually alosent. The three-lipped forms may possess eversible jaws or fringes of bristles. Oesophagus club-shaped, museular, relatively short, followed by a pyriform glandular bulb, with a long anterior portion or neek, which is sometimes narrower than the oesophagus proper. No eervical alae. 
Tail of male tapering, without alae. Reproductive organs simple. Spieules two. Vulva elose to anus, exceptionally with a common opening. Female genital tube single. Eggs few, very large. Viviparous.

Hab. Alimentary canal of Vertebrates.

\section{Atractis Dujardiu, 1845.}

Lips not distinct, apparently six. Neck of oesophageal bulb narrower than the oesophagus proper. Tail of male constrieted behind the anus to form a conical process. Nine pairs of caudal papillae present, of which six pairs are postanal. Spicules unequal and markedly dissimilar. In addition to these there is a tubular chitinoid accessory organ. Tail of female conical.

Hab. Alimentary canal of Tortoises and Iguanas.

Genotype : A. [Ascaris] dactyluris (Rudolphi, 1819).

Rudolphi, 1819, Entozoorum Synopsis, 40, 272; Schneider, 1866, Monographie der Nematoden, Berlin, 124; Drasche, 1884, Verhandl. k. k. Zool.-bot. Ges., Wien, xxxiii ; 328, Parona, 1887, Ann. Mus. Civ. Stor. Nat., Genova, xxiv, 344; v. Linstow, 1883, Arch. f. Naturg., xlix, 296; Gedoelst, 1919, Compt. rend. Soc. Biol., Paris, lxxxii, 910.

\section{Labiduris Schneider, 1866.}

Three large and distinct lips, the dorsal lip smaller than the two ventro-lateral and trilobed anteriorly, each ventrolateral lip with a eonieal proeess in front and a fringe of knobbed bristles behind. Tail of male sharply constricted behind the cloaca to form a long, slender terminal proeess. Ten to twelve pairs of caudal papillae present, of which four or five sessile pairs are preanal. The two most anterior pairs of postanal papillae very large and prominent, the most posterior pair supporting the posterior angles of small square alae. Spicules equal. Aceessory piece absent. Tail of female long and pointed.

Hab. Large intestine of Tortoises.

Genotype: L. [Ascaris] gulosa (Rudolphi, 1819).

Rudolphi, 1819, Entozoorum Synopsis, 40, 271; Selneider, 1866, Monographie der Nematoden, Berlin, 122; v. Linstow, 1899, Mitt. Zool. Mus., Berlin, i, 13; Gedoelst, 1919, Compt. rend. Soc. Biol., Abt. A, Paris, lxxxii, 912.

\section{Crossocephalus Railliet, 1909.}

Syn. Pterocephalus v. Linstow, 1899, nec Sehneider, 1887.

Three distinct lips, eaeh bearing two ehitinoid jaws with a terminal tooth and a row of bristles externally. The jaws SYN. NEM. 
are eversible, and when inverted are lodged in the anterior part of the lumen of the oesophagus. Behind the lips a euticular collar bearing a pair of prominent horn-like lateral papillae. Tail of male bluntly conical. Up to ten pairs of rather small eaudal papillae present. Spienles unequal. No accessory piece. Tail of female narrows suddenly behind the anus and tapers to a fine point.

Hab. Alimentary canal of Perissodactyle mammals.

Genotype: C. [Pterocephalus] viviparus (v. Linstow, 1899).

v. Linstow, 1899, Mitt. Zool. Mus., Berlin, i, 12; Railliet, 1909, Réc. Méd. Vét., Paris, lxxxvi, 336 ; Gedoelst, 1916, Rev. Zool. Afric., v, 1 ; Baylis, 1919, Ann. Mag. Nat. Hist. (9) iv, 94; Yorke \& Sonthwell, 1920, Ann.Trop. Med., Liverpool, xiv, 127.

4. Rondonia Travassos, 1920 (?).

Spicules subequal. A cloaca present in both sexes.

Hab. Alimentary canal of freshwater fishes (one species known).

Genotype: $R$. rondoni Travassos, 1920 (?).

Travassos, 1920 (?), Rev. Vet. e Zootech., Rio de Janeiro, 62.

\section{Cobboldina Leiper, 1911.}

Syn. Cobboldia Leiper, 1910.

Lips not apparent. Mouth surrounded by a euticular collar with median dorsal and ventral prolongations. The collar is supported by four finger-like papillae, the lateral pair longer than the median. Length of the posterior oesophageal bulb and its "neck" almost twice that of the oesophagus proper. Tail of male long and tapering. Nine pairs of sessile caudal papillae present, of which four are postanal. Spieules unequal. No accessory piece.

Hab. Stomach of Hippopotamus (one speeies known).

Genotype: C. [Cobboldia] vivipara (Leiper, 1910).

Leiper, 1910, Proc. Zool. Soc., London, 235; 1911, Proc. Zool. Soc., London, 555; Gedoelst, 1919, Compt. rend. Soc. Biol., Paris, lxxxii, 912.

6. Cyrtosomum Gedoelst, 1919.

Mouth hexagonal, with six lips. No buecal capsule. Tail of male conieal. Six pairs of caudal papillae present, of which three are preanal and three postanal, near the tip of the tail. Spieules equal, sharply pointed. Aceessory piece absent.

Hab. Alimentary canal of a Lizard (one speeies known).

Genotype: C. scelopori Gedoelst, 1919.

Gedoelst, 1919, Compt. rend. Soc. Biol., Paris, lxxxii, 910. 
7. Monhysterides Baylis \& Daubney, 1922.

Lips apparently six, small. Oesophagus with short, muscular anterior portion and longer, partly glandular, posterior "bulb." Candal end of male tapering, with five pairs of postanal and four pairs of preanal papillae, the latter being very close together, subventral and prominent. Spicules unequal, tubular, the longer blunt, the shorter pointed. No accessory piece.

Hab. [Alimentary canal of] a Fish.

Genotype : M. piscicola Baylis \& Daubney, 1922.

Baylis and Daubney, 1922, Mem. Ind. Mus., vii, 342.

8. Leiperenia Khalil, 1922.

Lips "more than six." Oesophagus proper very short; the posterior bulb, with its "neck," about three times as long. Tail of male tapering. Four small postanal papillae at about the middle of the tail. Spicules unequal. An accessory piece present. Tail of female long and slender.

Hab. Alimentary canal of Elephants.

Genotype : L. leiperi Khalil, 1922.

Khalil, 1922, Ann. Mag. Nat. Hist., (9) ix, 215; 1922, Proc. Zool. Soc. London, 206.

\section{Fam. 7. RHABDITIDAE Micoletzky, 1922.}

Small forms, free-living or parasitic, or with both freeliving and parasitic phases, with a three-sided, prismatic or tubular buccal cavity, usually without teeth. Oesophagus usually with a posterior bulb containing valves, and frequently also with a prebulbar swelling. Cuticle without bristles, or with very few. Reproductive organs simple. Oviparous or viviparous, not infrequently parthenogenetic or hermaphrodite.

This family is divided by Micoletzky (1922, Arch. $f$. Naturg., lxxxvii) into four subfamilies (Cylindrolaiminae, Plectinae, Rhabditinae and Bunoneminae). We have been unable to find sufficient characters to separate the Plectinae from the Cylindrolaiminae, and have therefore merged these two groups into a single one. The subfamily Bunoneminae consists of two genera which possess very well-marked and obvious characters. The distinctions between the Rhabditinae and Cylindrolaiminae are not felt to be very satisfactory, but these two groups are, for the present, retained.

Subfam. 1. RHABDITINAE Micoletzky, 1922.

Buccal cavity elongate, typically a three-sided tube withont tooth-like structures. Lateral organs and caudal glands 
generally absent. Excretory system typically in the form of lateral canals. Testis usually single.

We have included in this subfamily several partially parasitic genera which have previously been referred to other groups. The structure of the free-living forms of Rhabdias and Strongyloides indicates their close relationship to Rhabditis. We have therefore suppressed the family Rhabdiasidae (Railliet, 1915) (= Angiostomidae Braun, 1895). There appears to be no reason why the genera Lepidonema, Hystrignathus and Heth should not also be included in the Rhabditinae, and we have adopted this classification, the family Lepidonemidae (Travassos, 1920 (?)), with its subfamilies Lepidoneminae and Hystrignathinae, being therefore discarded.

The family Mermithidae (Braun, 1883) is considered as having relationships on the one hand with the Rhabditidac, and on the other hand with the Anguillulinidae. It is possible that a more comprehensive study of this highly-specialized group would lead to its inclusion in one of these families. We have accordingly compromised by retaining the family Mermithidae.

The superfamily Rhabdiasoidea (Railliet \& Henry, 1916) (= Angiostomoidea Hall, 1916) included, according to Travassos (1920 (?)), the families Rhabdiasidae, Mermiidae [sc. Mermithidae], Lepidonemidae, Isakidae and Atractidac. Isakis, the sole representative of the Isakidae, has been transferred to the Oxyuridae, and the family Atractidae is also regarded as part of the order Ascaroidea. This disposes of all the contents of the superfamily Rhabdiasoidea, which accordingly disappears.

\section{Rhabditis Dujardin, 1845.}

Syn. Tribactis Dujardin, 1845; Angiostoma Dujardin, 1845, e. p. ; Ascaroides Barthélemy, 1858; Pelodytes Schneider, 1859; Pelodera Schmeider, 1866.

Cuticle smooth or striated. Lateral alae usually absent. Head usually distinct, without lips or with either three or six lips, bearing papillae or bristles. Buccal capsule a cylindrical or three-sided chitinoid tube, usually interrupted by a nonehitinized portion near its posterior end. Oesophagus usually with two swcllings, of which the posterior is a muscular bulb. Tail of male with bursa-like alae supported by five to ten pairs of pedunculate papillac. Spicules two, equal, rarely fused. An accessory picce usually present. Testis single, reflexed. Tail of female more or less pointed. Vulva commonly in the middle of the body, with opposed genital tubes and reflexed ovaries; more rarely posterior, with a single anterior genital tube. Oviparous, sometimes viviparous. 
Hab. Decaying material, damp soil or water (fresh or marine). Some species parasitic, chiefly in insects.

Genotype : $R$. terricola Dujardin, 1845.

Dujardin, 1845, Histoire naturelle des Helminthes, Paris, 239 ; de Man, 1884, Die frei . .". lebenden Nematoden der Niederl. Fauna, Leiden, 118; Micoletzky, 1922, Arch. f. Naturg., Abt. A, lxxxvii, 245.

\section{Rhabdias Stiles \& Hassall, 1905.}

Syn. Angiostoma Dujardin, 1845, e. p. (Angiostoma and Angiostomum auctt.); Rhabdonema Leuckart, 1879, et auctt., e. $p$.

Free-living generation. Microscopic forms. Sexes separate. Body fairly stout. Mouth without lips. A short buccal capsule present. Ocsophagus with a fusiform prebulbar swelling and a pyriform posterior bulb. Tail of male conical, with a short terminal spike and narrow lateral alae. Four pairs of preanal and three pairs of postanal papillae present, all lateral in position. Spicules equal, short and stout. Apparently no accessory piece. Tail of female conical. Vulva somewhat behind middle of body. Uterine branches opposed. Eggs very few and large. Embryos hatch within the uterus, and are retained until the death of the female.

Parasitic generation. Much larger than the free-living generation, and consisting of "female" forms only (protandrous hermaphrodites). Slender forms, without lips. A short, cup-shaped buccal capsule present. Oesophagus cylindrical, with a slight constriction about the middle, and without a posterior bulb. Tail conical. Vulva near the middle of the body, opening directly into the uterine branches, which are opposed. Ovaries reflexed. Eggs segmenting when laid.

Hab. Lungs of Amphibians and Reptiles. (Free-living stages in faeces of these animals or in the soil).

Genotype : R. [Ascaris] bufonis (Schrank, 1788).

Schrank, 1788, Verzeichniss der . . Eingeweidewiirmer, München, 11; Dujardin, 1845, Histoire naturelle des Helminthes, Paris, 262 (Angiostoma entomelas, not $A$.limacis); v. Linstow, 1890, Arch.f. Naturg., i, 185; Stiles \& Hassall, 1905, U.S. Dept. Agric., Bur. Anim. Indust. Bull. 74, 123, 150 ; Schleip, 1911, Arch.f. Zellforschg., Leipzig, vii, 87.

\section{Strongyloides Grassi, 1879.}

Syn. Rhabdonema Leuckart, 1879, et auctt., e. p. ; Pseudorhabditis Perroncito, 1880, nec Szüts, 1912; Stercoralis Tanaka, 1910.

Free-living generation. Microscopic forms, comparatively stout. Sexes separate. Mouth with four indistinct lips and 
six papillae. A short, eylindrical buccal capsule present. Oesophagus club-shaped, connected by a narrow neck with a pyriform posterior bulb. Tail of male short, conical. At least one pair of preanal and one pair of postanal papillae present. Spicules short, stout, equal. An accessory piece present. Tail of female somewhat longer, tapering. Vulva near the middle of the body, opening directly into the uterine branches, which are opposed. Ovaries reflexed. Eggs few and large, oval, thin-shelled, segmenting when laid, or, in the case of older females, hatching in utero.

Parasitic generation. Body considerably longer than in the free-living generation, and very slender. Consisting of "female" forms only. Mouth with four indistinct lips. A short buccal capsule present. Oesophagus long, slender, almost cylindrical, without a posterior bulb. Tail short, conical. Vulva in posterior half of body, opening directly into uterine branches, which are opposed. Ovaries reflcxed. Eggs segmenting when laid.

Hab. Intestine of Vertebrates. (Free-living stages in faeces of these animals or in the soil).

Genotype : S. [Anguillula] stercoralis (Bavay, 1876).

Bavay, in Normand, 1876, Compt. rend. Acad. Sci., Paris, lxxxiii, 316; Grassi, 1879, Med. Contemp., Milano, An. 2, iii, 497; Looss, 1911, Rec. Egypt. Govt. School Med., Cairo, iv, 215.

\section{Anguillula Ehrenberg, 1831.}

Cuticle extremely finely striated, with narrow lateral alae but without bristles. Head rounded or truncate, with more or less distinct lips and one or two crowns of papillae. Lateral organs apparently unknown. Buccal capsule small, thinwalled, hexagonal anteriorly, but for the most part threesided, and consisting of two parts, of which the posterior contains (in the genotype) a very small dorsal tooth and two subventral processes. Oesophagus with a distinct posterior bulb. Caudal end of male with preanal and postanal papillae. A single accessory piece present. Spicules equal, broad. Testis single, anterior, sometimes reflexed. Female genital tubes paired, opposed, the anterior only with an ovary, which is reflexed; the posterior vestigial, apparently serving as a receptaculum seminis. Ovoviviparous. Caudal glands absent. Excretory system consists of paired lateral canals.

Hab. In decaying substances, stagnant water, etc.

Genotype: A. [Vibrio] aceti (Müller, 1783).

Müller, 1783, 162 [fide Stiles \& Hassall, not verified]; 1786, Animalcula infusoria, 63; Ehrenberg, 1831, Symbolae physicae(Evertebrata), Series Prima, Phytozoa Entozoa; Bastian, 
1865, Trans. Linn. Soc. London, xxv, 110; Stiles \& Hassall, 1905, U.S. Dept. Agric., Bur. Anim. Indust. Bull. 79, 34; de Man, 1910, Zool. Jahrb., Syst., xxix, 362; Goodey, 1922, Ann. Mag. Nat. Hist., (9) x, 297.

The original diagnosis of this genus given by Ehrenberg (1831) is valueless from the modern standpoint, as is that of the probable genotype, A. fluviatilis (=Vibrio anguillula fluviatilis Müller, 1786). Müller, 1786, is quoted by Stiles \& Hassall (1905) as an earlier author of the name Anguillula. Müller, however, appears to us, in spite of Stiles \& Hassall's statement, to have used this name in 1786 in a specific sense only, in combination with Vibrio as genus. Some of the forms included in Vibrio were given trinomial names (Vibrio anguillula aceti, etc.). Hence the author of the generic name Anguillula is Elirenberg. As the species fluviatilis and the other species attributed to the genus by Ehrenberg in 1831 are probably unrecognizable, it seems advisable to regard as genotype one of the easily-recognized species $A$. aceti or $A$. rediviva $(=A$. glutinis), which were included by the same author later (1838) in the genus. Bastian (1865) designated the species aceti (Müller) as type of Anguillula Ehrenberg, and this designation does not appear to be invalidated by Stiles \& Hassall's argument that $A$. rediviva (= glutinis) is the type of "Anguillula Müller." Accordingly, we have made de Man's (1910) diagnosis, based on the species aceti, the chief source of the characters given above. $A$. rediviva differs only in minor points from $A$. aceti, so that for practical purposes it is of little importance which is regarded as typical.

\section{Diploscapter Cobb, 1913.}

Cuticle extremely finely striated, without bristles. Lateral alae more or less well developed. Lips four, of which the dorsal and ventral each carries a powerful, outwardly-directed, chitinoid hook-like tooth. Lateral lips larger. Buccal capsule prismoid, with uninterrupted wall. Oesophagus with median and posterior swellings, the latter a muscular bulb. Tail in both sexes fairly long, conical, with fine point. Male with candal alae supported by seven pairs of papillae. Testis single. Vulva slightly behind the middle of the body. Uterine branches opposed. Oviparous. Eggs with rough shell. Uterus contains only one egg at a time.

Hab. About roots of diseascd plants; cosmopolitan but usually tropical.

Genotype : D. [Rhabditis] coronata (Cobb, 1893).

Cobb, 1893, Macleay Mem. Vol. Linn. Soc. N.S.W., Sydney, 279, 305; 1913, Journ. Washington Acad. Sci., 442; Micoletzky, 1922, Arch.f. Naturg., Abt. A, lxxxvii, 266. 


\section{Cephalobus Bastian, 1865 .}

Cnticle striated. Lateral alae present, but sometimes very slight. Head not distinet. Lateral organs absent or very inconspicnons. Three more or less distinct lips, sometimes bilobed. A single erown of three or six labial papillae present. Cephalic bristles absent. Buccal capsule usually pyramidal or prismoid, its wall composed of two or three rings of longitudinal rods. Oesophagns with a museular posterior bulb, and sometimes with a slight prebulbar swelling. Tail of male without alae. Preanal and postanal papillae present. Spicules equal, slightly eurved, fusiform. One or two aceessory pieces present. Testis single. Vulva at abont the posterior third of the body. Female genital tubes paired, opposed; the posterior branch is vestigial and withont ovary. The anterior ovary is often reflexed. Usually oviparous. Spinneret absent.

Hab. Usually free-living, in soil or decaying matter; also in fresh water. Sometimes parasitic or semi-parasitic.

Genotype: C. persegnis Bastian, 1865.

Bastian, 1865, Trans. Linn. Soc. London, xxv, 124; Micoletzky, 1922, Arch.f. Naturg., Abt. A, lxxxvii, 267; Cobb, 1924, Journ. Parasitol., xi, 108.

6a. Acrobeles v. Linstow, 1877.

Subgenus of Cephalobus. Differs from type in the presence of cephalic bristles and spines.

Hab. Soil.

Type: A. ciliatus v. Linstow, 1877.

v. Linstow, 1877, Arch. f. Naturg., i, 2; Micoletzky, 1922, Arch. f. Naturg., Abt. A, lxxxvii, 268; Cobb, 1924, Journ. Parasitol., xi, 108 ; Thome, 1925, Trans. Amer. Microsc. Soc., xliv, 171 .

Cobb (1924) maintains Acrobeles as a well-founded genus, and characterizes it as follows: "Acrobeles von Linstow amend. Characters of Cephalobus Bastian amend., but having also a second inner eirelet of labial organs, often simple and conoid, sometimes relatively long and branched, in which ease the outer may also become componnd. Pharynx narrower, and uniform, with fewer separate cutieular elements. Amphids though small usually visible, traversely elongate on outer surface of lip region.'

He adds: "The future may very probably disclose reasons for subdividing Acrobeles as thus defined and designating separately a group (Acrobeloides gen. (aut. subg.) nov.) between Cephalobus and Acrobeles sensu restrieto-eharacterized by having the inner and outer labial organs simple." See also Thorne (1925). 
7. Macrolaimus Maupas, 1900, nec Ditlevsen, 1919.

Cuticle very finely striated. Head without lips. Mouth widely open, bordered by six short, stout bristles. Buccal cavity wide, cup-shaped, its wall in two portions, the anterior thin and transparent, the posterior thick and dark-coloured. Oesophagus with thick anterior portion, separated by a long, narrow neck from a well-developed posterior bulb. Parthenogenetic. Female genital tube single, anterior, with long reflexion. Oviparous. Excretory system consists of lateral canals.

Hab. Soil.

Genotype : M. crucis Maupas, 1900.

Maupas, 1900, Arch. Zool. exp. et gén., Paris, (3) viii, 578.

8. Diplogaster M. Schultze, in Carus, 1857.

Syn. Diplogasteroides de Man, 1912 ; Rhabditolaimus Fuchs, 1916 ; Fuchsia Micoletzky, 1922.

Cuticle with transverse and also longitudinal striations. Head not distinct, sometimes with lips, sometimes with one or two crowns of small bristle-like papillae. A fold of cuticle, which may be longitudinally ribbed, sometimes present immediately behind the mouth. Lateral organs variable, probably always present, occasionally showing sexual differences. Buccal capsule wide and often deep, bnt variable in shape, thick-walled, with one large (dorsal) or two or three small, movable teeth at its base, or without teeth. Oesophagus with a muscular anterior bulb and a non-muscular posterior bulb-like swelling. Caudal end of male with or without alae, and with nine or ten pairs of papillae. In forms without alae the papillae are usually bristle-like. Two spicules and an accessory piece, of very variable shape, present. Testis usually single. Female genital tubes usually paired, opposed, reflexed. Usually oviparous, sometimes viviparous. Some species hermaphrodite, according to Cobb. Caudal glands absent.

Hab. Fresh water, soil, decaying matter. Some species have been found on plants, others in dead insects. It is uncertain whether any are true parasities.

Genotype : D. micans M. Schultze, in Carus, 1857.

Max Schultze, in Carus, 1857, Icon. Zootom., Erste Hälfte, Pl. VIII, fig. I ; de Man, 1884, Die frei . . . lebenden Nem. der Niederl. Fauna, 84; Fuchs, 1915, Zool. Jahrb., Syst., xxxviii, 158; Cobb, 1918, in Ward and Whipple, Freshwater Biology, 488; Micoletzky, 1922, Arch.f. Naturg., Abt. A, lxxxvii, 402.

Micoletzky (1922) divides this genus into two subgenera, Diplogaster and Fuchsia. The latter appears to be identical 
with Rhabditolaimus, proposed as a genus by Fuchs, 1915. Apart from the fact that the species attributed to Rhabditolaimus are found associated, in a semi-parasitic condition, with insects, the only differences between the subgenera appear to be that in Rhabditolaimus the enticle is, in speeies with a typical buceal cavity, marked with longitudinal striations resolvable into groups of dots, and in the other speeies the teeth are absent or rudimentary; while in Diplogaster the euticle, if longitudinally striated, is not marked with groups of dots. These distinetions seem highly unsatisfactory, and the subgenera untenable. Diplogasteroides does not appear to possess sufficient characters to separate it from Diplogaster.

9. Demaniella Steiner, 1914.

Syn. Demania Steiner, 1914, nec Laurie, 1906, nec Southern, 1914.

Cutiele finely striated. Head not distinct, bluntly rounded, without lips, papillae or bristles. A small, conical, perforated stylet in front, and surrominding it at a short distance nine small creseentic cuticular thickenings. Buceal eavity prismatic, with rod-like chitinoid thickenings, and at its base a large dorsal tooth. Oesophagus with a median cylindrical muscular bulb and a slight posterior bulb. Male unknown. Female genital tubes paired.

Hab. Among rotting grass.

Genotype : D. [Demania] cibourgensis Steiner, 1914.

Steiner, 1914, Arch.f. Hydrobiol. u. Planktonk., Stuttgart, ix, 426 .

\section{Chambersiella Cobb, 1920.}

Cuticle very finely striated, without bristles. Lateral alae present. Lateral organs transversely oval. Six branehed, non-motile, cephalic cirri present, and behind these six short bristles with swollen bases. Buccal capsule like that of Cephalobus, but not tapering posteriorly, with walls composed of rods, and with six powerful, protrusible labial teeth anteriorly. Oesophagus with a cylindrical prebulbar swelling and a posterior bulb. Tail conical, with tip hooked dorsally, and with paired lateral pores. Tail of male without alae, but with numerous preanal and postanal papillae. Spieules knobbed. An accessory piece present. Testis single, reflexed. Vulva prominent, slightly behind the middle of the body. A single uterine branch, anterior, with ovary reflexed and running posteriorly to near the anus. Eggs segmenting when laid.

Hab. On bark of trees, and in moss.

Genotype: C. rodens Cobb, 1920.

Cobb, 1920, Contr. Sci. Nematol., ix, 278; Micoletzky, 1922, Arch.f. Naturg., Abt. A, lxxxvii, 297. 


\section{Teratocephalus de Man, 1876.}

Cuticle transversely striated, the striations usually com. posed of rows of dots, withont bristles. Lateral organs, when present, small and spiral. Head may or may not be distinct, and has six movable cuticular flaps or lips, separated by deep furrows. Buccal capsule goblet-shaped, wide anteriorly and narrow posteriorly, and with isolated chitinoid elements. Oesophagus with a posterior bulb not separated by a distinct "neck" from the more or less cylindrical prebulbar swelling. Male with slender spicules. No accessory piece or caudal papillae. Vulva in the middle of the body or slightly posterior. Uterine branches opposed, usually with reflexed ovaries. In the genotype the posterior branch is reduced and without ovary.

Hab. In soil, on plants or in fresh water.

Genotype : T. [Anguillula] terrestris (Bütschli, 1873).

Bütschli, 1873, Nov. Act.k.Leop.-Car. Akad. Naturf., Dresden, xxxvi, 69; de Man, 1876, Tijdschr. Nederl. dierk. Vereen., 's Gravenhage and Rotterdam, 137; 1884, Die frei . . lebenden Nematoden der Niederl. Fauna, 101; Micoletzky, 1922, Arch. f. Naturg., Abt. A, lxxxvii, 298.

\section{Rhabdolaimus de Man, 1880 .}

Cuticle with fine transverse striations, without bristles or lateral alae. Lateral organs small, inconspicuous. Anterior end bluntly rounded, without lips, papillae or bristles. Buccal capsule very long and narrow, supported by three slender chitinous rods which converge slightly posteriorly and are connected anteriorly with hook-like or knob-like structures. Oesophagus with muscular posterior bulb. Tail long and tapering, with caudal glands and spinneret. Males rare, with stout spicules. Two chitinized thickenings of the cloacal wall represent rudimentary accessory pieces. No caudal papillae or alae. Vulva in middle of body. Uterine branches probably opposed.* Frequently parthenogenetic.

Hab. Damp soil, sand or fresh water.

Genotype: $R$. terrestris de Man, 1880.

de Man, 1880, Tijdschr. Nederl. dierk. Vereen., Leiden, 59 ; 1884, Die frei . . lebenden Nematoden der Niederl. Fauna, 125; Micoletzky, 1922, Arch.f. Naturg., Abt. A, lxxxvii, 302.

\section{Protrellus Cobb, 1920.}

Cuticle with transverse striations, rather coarse in the female, much finer in the male, and without bristles. Cuticle of neck inflated in the adult only. Lateral organs absent. Lateral fields broad, without alae. Head truncate, with

* According to de Man, the female organs are apparently unpaired, although extending on either sido of the vulva. 
apparently six small indistinct lips, each with at least one papilla, and constricted off from the body. Buccal capsule prismoid, one-half to two-thirds as wide as long. Oesophagus with slight prebulbar swelling and ovoid posterior bulb, separated by a distinct constriction. Spinneret absent. Tail of male tapering, with three pairs of subventral papillae (one large pair preanal, two small pairs postanal). A single slender, pointed spicule. A small accessory piece doubtfully present. Testis single, reflexed. Tail of female stout at the base, conical posteriorly. Vulva very prominent, in front of oesophageal bulb. Vagina muscular. A single, posterior, uterus present, with two posterior, doubly reflexed ovaries. Eggs with the less pointed end, which is directed away from the vulva, "saddled" with a peculiar organ.

Hab. Rectum of a Cockroach (Polyzostaria). Australia.

Genotype: P. aureus Cobb, 1920.

Cobb, 1920, Contr. Sci. Nematol., ix, 256 and key.

14. Blattophila Cobb, 1920.

Cuticle with plain transverse striations, without alae or bristles. Lateral organs absent. Head rounded, with very small lips forming almost an annular elevation. Buccal capsulc very short, prismoid, about half as wide as long, with apophyses springing from its base, a dorsal one predominating, the whole contained in a small, spherical pharyngeal bulb. Oesophagus with club-shaped prebulbar swelling and distinct posterior bulb. Tail conical, pointed, without spinneret. Anterior lip of anus prominent. In the male two large sub. median preanal papillae and two smaller postanal papillae present. Spicules rudimentary. A single testis, reflexed. Vulva not prominent, in the anterior third of the body. Ovaries paired, parallel, posterior and reflexed. Eggs numerous, elongated and ellipsoidal; may be segmenting when laid.

Hab. Intestine of a Cockroach (Panesthia). Australia.

Genotype: B. sphaerolaima Cobb, 1920.

Cobb, 1920, Contr. Sci. Nematol., ix, 271 and key.

15. Cephalobium Cohb, 1920.

Cuticle with fine transverse striations. Lateral alae present. Lateral organs absent. Lateral fields each contain about thirteen pores, of which the posterior pair is on the tail. Head with six bristle-like papillae. Buccal capsule composed of two portions and with a large, complex "glottoid organ" at its basc. Oesophagus with a pronounced prebulbar swelling, in front of the nerve-ring, and a very slight posterior bulbous swelling. Tail conical, without spinneret. In the male one pair of preanal papillae and five pairs of postanal papillae 
present. Spicules two, slender, tapering, ending in minute "buttons," and with four slender supporting rods towards their distal ends. A strong, straight accessory piece present. Testis single, not reflexed. Vulva prominent, at about the middle of the body. Ovaries opposed, reflexed.

Hab. Intestine of a Cricket (Gryllus).

Genotype: C. microbivorum Cobb, 1920.

Cobb, 1920, Contr. Sci. Nematol., ix, 270 and key.

16. Lepidonema Cobb, 1898.

Cuticle, at least in anterior region, bearing longitudinal rows of scales. Head narrower than neck. Lips obscure. A very short buccal capsule present. Oesophagus clubshaped, with a distinct pyriform posterior bulb. Tail of male short, conical, ending in a short spike, and with a pair of large postanal papillae near the tip. A pair of small preanal papillae present. Spicules paired (?), short. Accessory piece apparently absent. Tail of female conical, with bifurcated tip. Vulva a little behind the middle of the body. Uterine branches opposed. Ovaries reflexed.

Hab. "In the larva of an insect" (one species known).

Genotype: L. bifurcata Cobb, 1898.

Cobb, 1898, Agric. Gaz. N.S.W., Sydney, ix, 315.

The only description available is contained in Cobb's fig. 36 , with its legend and formula.

\section{Hystrignathus Leidy, 1850.}

\section{Syn. Xyo Cobb, 1898.}

Anterior region of body bearing transverse rows of simple, backwardly directed spines or scales. Mouth on the summit of a large, naked cone. Oesophagus long, cylindrical, ending in a distinct pyriform posterior bulb with a narrow neck. There is apparently a short pharynx, narrower behind, and with longitudinal supporting rods. Male unknown. Tail of female tapering. Vulva slightly behind middle of body. Uterine branches opposed. Ovaries reflexed. Eggs oval.

Hab. Intestine of Beetles (Passalus).

Genotype : H. rigidus Leidy, 1850.

Leidy, 1850, Proc. Acad. Nat. Sci. Philadelphia, v, 102 ; 1853, Smithsonian Contr. Knowl., Washington, v, 44; Cobb, 1898, Agric. Gaz. N.S.W., Sydney, ix, 315; Johnston, 1913, Proc. R. Soc. Queensland, Brisbane (1912), 75.

\section{Heth Cobb, 1898.}

Head narrower than body, separated from it by a constriction, and provided externally with four submedian double 
fringes. Neck ornamented with fringed "epaulettes," and behind these two pairs of lateral bifureated lappets. Mouth a vertical (?) slit, bordered with fringes. Apparently eight setiform cephalic papillae and two circular lateral organs present. Oesophagus preceded by a tubular pharynx, and followed by a pyriform muscular bulb. Male undescribed. Tail of female tapering. Vulva near anus. Uterine branches parallel. Ovaries reflexed. Eggs segmenting when laid.

Hab. Intestine of a Myriopod (Julus). (One species known).

Genotype: H. juli Cobb, 1898.

Cobb, 1898, Agric. Gaz. N.S.W., Sydney, ix, 299.

The only description available is contained in Cobb's fig. 10, with its legend and formula. According to the legend, the organs which we have called lateral organs in our diagnosis are "two dorso-ventral markings." This would imply that the mouth is a horizontal slit, and not a vertical one as we have stated. On the other hand, the paired cervical organs which we have called lappets are termed by Cobb "dorsoventral fins," but are figured (figs. II and IV) as being lateral in position.

\section{Appendix to Rhabditinae.}

The following two genera should probably be regarded as Rhabditinae greatly modified in consequence of their highlyspecialised habits.

\section{Allantonema Leuckart, 1884.}

Syn. Bradynema zur Strassen, 1892; Tylenchomorphus Fuehs, 1914; Howardula Cobb, 1921.

Parasitic form (female), when fully grown, more or less sausage-shaped, without month, anus or alimentary eanal. Genital tube single, the uterus greatly swollen and filling almost the whole body-cavity. Vulva at or near the posterior end of the body. Ovary long, doubly reflexed. Viviparous, numerous embryos escaping into the body-cavity of the host, and finally to the exterior.

Free-living form (bisexual) of typical Nematode shape. Head truncate, with very small lips. Oesophagus with a muscular anterior portion ending in a bulb, followed by a clubshaped glandular portion. A short, three-sided buccal capsule present. Tail conical in both sexes. In the male, the tail ends in a small spike, has narrow alae, and may carry two pairs of small preanal papillae. Spieules paired, short and slender. A very small accessory piece present. Vulva slightly behind the middle of the body. Female genital tubes paired, opposed, reflexed. Oviparous. Eggs few, segmenting when laid. 
Hab. Parasitic forms in body-cavity of Beetles and their larvae, either free or encapsuled. Free-living forms in soil, or in material on which the beetles feed.

Genotype: A. mirabile Leuckart, 1884.

v. Siebold, 1836, Arch. f. Anat., Physiol. u. wiss. Med., Berlin, 33 ; Leuckart, 1884, Tagebl. 57 Versamml. deutsch. Nat. u. Aerzte, Magdeburg, $320 ;$ 1887, Abh. Math.-Phys. Cl. $k$. Sachs. Ges. Wiss., Leipzig, xiii, 567; zur Strassen, 1892, Zeitschr.f. wiss. Zool., liv, 655; Fuchs, 1914, Zool. Jahrb., Syst., xxxviii, 183; Cobb, 1921, Science, liv, 667; Wülker, 1923, Zool. Anz., lvi, 160.

The parasitic stages of Allantonema [Filaria] rigida (v. Siebold, 1836), which was made by zur Strassen the type of a new genus, Bradynema, seem to agree in all essential characters with those of $A$. mirabile. Its free-living stages have not been described. zur Strassen was led to believe that, though the larvae which escaped to the exterior from the host developed into forms of both sexes, only the male forms took any part in the propagation of the race. These, he believed, penetrated into new hosts and became protandrous hermaphrodites, while the young potential females died, without becoming parasitic or giving birth to any offspring. In $A$. mirabile, according to Leuckart, there is a definite alternation of generations, the parasitic form, which is the offspring of the fertilized free-living female form, being a protandrous hermaphrodite. On the other hand, Wülker, as the result of a recent re-study, states that the parasitic form is the female free-living form itself, which is fertilized before penetrating into the host. $\mathrm{He}$ believes that the life-history is probably similar in Bradynema, Sphaerularia, Atractonema and Howardula.

\section{Sphaerularia Dufour, 1837.}

Syn. Atractonema Leuckart, 1887, nec Stein, 1878; Asconema Leuckart, 1887, nec Askonema Kent, 1870.

Parasitic form (female) penetrates into host probably immediately after fertilization. Here the vaginal region of the ventral surface grows out into a long appendage (finally becoming many times as large as the body of the worm), into which pass the uterus and fat-body or modified intestine. The body then becomes an empty sac, and may ultimately become detached. Embryos hatch in utero and escape into bodycavity of host.

Free-living form. The larva, after leaving the host, lives for several months without taking food. The mouth is completely closed by a stylet-like organ (which, according to Leuckart, is not a true stylet, and which may perhaps represent the buccal capsule). Oesophagus with median and posterior 
fusiform swellings. Intestine a fat-body, without funetional anus. The mature forms retain the stylet-like organ and the same structure of the alimentary canal. The head is rounded, the tail conical. The male has two very short and slender spieules and a very small accessory picee. Male genital tube single, short and reflexed. Vulva towards the posterior end of the body. Female genital tubes paired, opposed, but only the anterior braneh of the uterus well developed and having a reflexed ovary; the posterior braneh a small blind appendage.

Hab. Parasitic stages in body-eavity of Insects. Freeliving stages in soil, ete.

Genotype: S. bombi Dufour, 1837.

Dufour, 1837, Ann. Sci. Nat., Paris, Zool., (2) vii, 9; Leuckart, 1886, Zool. Anz., ix, 743; 1887, Abh. Math.-Phys. Cl. k. Sachs. Ges. Wiss., Leipzig, xiii, 614, 678.

Atractonema gibbosum, the genotype of Atractonema, does not appear to possess characters sufficicntly distinctive to separate it gencrically from Sphaerularia.

\section{Subfam. 2. CYLINDROLAIMINAE Micoletzky, 1922.}

Buceal eavity elongate, typically cylindrical, without teeth. Lateral organs and caudal glands generally present. Excretory system usually in the form of a ventral unicellular gland.

1. Cylindrolaimus de Man, 1880.

Cutiele finely striated, without lateral alae or bristles. Head not distinet, withont lips or papillae, but with bristles. Buccal capsule an elongate, cylindrical, or probably prismatic tube. Oesophagus cylindrical, very little enlarged posteriorly. Latcral organs circular, situated anteriorly. Tail of male elongate, somctimes with terminal spike, with one or more median preanal papillae. Spicules slender, without midrib. No aecessory piece. Tail gland opens at the tip of the tail. Vulva in middle region or posterior part of body. Female genital tubes paired or unpaired.

Hab. In moist soil, sand or fresh water.

Genotype: C. communis de Man, 1880.

de Man, 18s0, Tijdschr. Nederl. dierl. Vereen., Leiden, 34; 1884, Die frei . . lebenden Nematoden der Niederl. Fauna, 82; Micoletzky, 1922, Arch.f. Naturg., Abt. A, lxxxvii, 204.

\section{Siphonolaimus de Man, 1893.}

Syn. Anthraconema zur Strassen, 1904.

Cuticle finely striated, with bristles. Hcad without lips, but with bristles. Mouth surrounded by six (?) small bristle- 
like papillae. Lateral organs circular. Buccal capsule shaped like a slender, inverted funnel, and resembling a "stylet." Oesophagus swollen in front and behind, without bulb. Caudal end of male with a median preanal series of numerous papillae. Spicules slender. An accessory piece, with two oblique posterior processes, present. Femalc genital tube single, anterior. Caudal glands present.

Hab. Marine.

Genotype: S. niger de Man, 1893.

de Man, 1893, Mém. Soc. Zool. France, vi, 99 ; zur Strassen, 1904, Zool. Jahrb., Suppl. vii, 302 ; Steiner, 1916, Zool. Jahrb., Syst., xxxix, 631.

\section{Chromagaster Cobb, 1894.}

Cuticular striations, if present, rery fine. Bristles present throughout the body, but conspicuons only towards the extremities. Cephalic bristles present, in two crowns. Neck constricted behind the lateral organs. Lips inconspicuous, sometimes six in number. Buccal capsule short, narrow and tubular. Oesophagus club-shaped, gradually expanding into a bulb. Tail of male conical. Spicules equal, slender. Two accessory pieces, somewhat L-shaped. Testis single. Vulva not conspicuous. Female genital tube single, outstretched. Caudal glands absent.

Hab. Marine, in mud or sand.

Genotype: C. purpurea Cobb, 1894.

Cobb, 1894, Proc. Linn. Soc. N.S.W., Sydney, viii, 416; Steiner, 1916, Zool. Jahrb., Syst., xxxix, 633.

According to Steiner (1916) Chromagaster nigricans, the second species of this genus, is to be referred to Siphonolaimus de Man, but it is uncertain whether the genotype of Chromagaster is also a Siphonolaimus. The genus Chromagaster is therefore retained.

\section{Camacolaimus de Man, 1889.}

Syn. Acontiolaimus Filipjev, 1918.

Cuticle striated. Short cephalic bristles present. Lateral organs circular, or incipient spirals. Buccal capsule small, thickened on the dorsal side to form a rod-shaped chitinoid structure or a "claw-shaped mobile tooth" (Filipjev). Oesophagus without bulb. Tail of male without preanal papillae. Two equal spicules and a small accessory piece. Female genital tubes symmetrical and reflexed. Caudal glands present.

Hab. Marine.

Genotype: C. tardus de Man, 1889.

SYN. NEM. 
de Man, 1889, Mém. Soc. Zool. France, ii, 8; Filipjev, 1918, Trav. Lab. Zool., Stat. Biol. Sebastopol, Ser. II, No. 4, 186; 1922, Act. Inst. Agronom. Stauropol, I, (Zool.), 16, 110.

5. Dermatolaimus Steiner, 1916.

Cuticle striated. Body without bristles. Four submedian cephalic bristles present. Head distinct, abruptly conical. Lateral organs circular, incomplete behind, with posterior prolongations. Apparently no lips. Buccal capsule very narrow and elongated. Oesophagus slender, expanding gradually into a posterior bulb. Male unknown. Female genital tubes paired, symmetrieal, reflexed.

Hab. Marine, aretic.

Genotype: D. ditlevseni Steiner, 1916.

Steiner, 1916, Zool. Jahrb., Syst., xxxix, 603.

\section{Gymnolaimus Cobb, 1913.}

Cuticle unstriated. Lips inconspicuous, three in number (?). Cephalic bristles absent. Lateral organs absent. Buccal capsule very long, slender. Oesophagus cylindrical, joined by a narrow neck to a pyriform bulb. Tail in both sexes long and tapering. Vulva at about the middle of the body. Female genital tube single, outstretched. Caudal glands and spinneret absent.

Hab. Soil.

Genotype: G. [Aulolaimus] exilis (Cobb, 1893).

Cobb, 1893, Macleay Mem. Vol., Linn. Soc. N.S.W., Sydney, 289; 1913, Journ. Washington Acad. Sci., 434.

\section{Leptolaimus de Man, 1876.}

Cuticle of body striated, with lateral alae and occasional bristles. Head distinct, without lips or bristles. Lateral organs circular. Buccal capsule an elongate, thin-walled tube. Oesophagus cylindrical, swollen into a bulb posteriorly. Tail of male slender, with several lateral "bristle-papillae" and with a knob-like termination on which the caudal gland opens. A median row of preanal papillae present, extending from just in front of the cloaea to the posterior oesophageal region, the four most anterior papillae being tubular and chitinized. Spieules slender. A single accessory piece present.

Hab. Soil, or brackish water.

Genotype: L. papilliger de Man, 1876.

de Man, 1876, Tijdschr. Nederl.dierk. Vereen., 's Gravenhage and Rotterdam, 168; 1854, Die frei . . lebenden Nematoden der Niederl. Fauna, 81. 
8. Aulolaimus de Man, 1880.

Cuticle unstriated. No lateral alae or bristles. Head not distinct, without lips or bristles. Lateral organs apparently absent. Buccal capsule an elongate, thin-walled, narrow tube, much longer than the oesophagus. Tail of male with a few median preanal papillae. Spicules slender. A single accessory piece, bent posteriorly. Female genital tubes paired, symmetrical. Caudal gland apparently absent.

Hab. Sandy soil or fresh water.

Genotype: A. oxycephalus de Man, 1880.

de Man, 1880, Tijdschr. Nederl. dierk. Vereen., Leiden, 30; 1884, Die frei .. lebenden Nematoden der Niederl. Fauna, 78.

9. Isolaimium Cobb, 1920.

Cuticle apparently unstriated. Lips and cephalic bristles absent. Buccal capsule tubular. Oesophagus "plain," without median or posterior enlargement. Tail of male bluntly conical, with four pairs of papillae. Six papilliform supplementary organs present. Spicules slender, blunt. A single slender accessory piece present, with a very small posterior process. Testes paired, opposed, ontstretched. Female genital tubes opposed, reflexed.

Hab. Soil.

Genotype : I. papillatum Cobb, 1920.

Cobb, 1920, Contr. Sci. Nematol., ix, 258 and key.

10. Cryptonchus Cobb, 1913.

Cuticle finely striated, without bristles. Lateral alae present. Head not distinct, with six indistinct lips and a crown of very small papillae. Buccal capsule tubular, like that of Cylindrolaimus, but with a small dorsal tooth at its base. Oesophagus without bulb. Male unknown. Vulva in middle region of body. Female genital tube single, outstretched. Caudal glands and spimneret present.

Hab. About roots of fresh-water plants.

Genotype: C. nudus Cobb, 1913.

Cobb, 1913, Journ. Washington Acad. Sci., 441 ; Micoletzky, 1922, Arch.f. Naturg., Abt. A, Ixxxvii, 210.

\section{Ceramonema Cobb, 1920.}

Cuticle with coarse annulations, each composed of eight imbricated elements. Neck region with small bristles in longitudinal rows. Six cephalic bristles present. Lips indistinct. Lateral organs crook-shaped. Buccal capsule very slender. Oesophagus "plain," slightly expanded behind. 
Male of genotype unknown. In another species, tail of male without supplementary organs. Spicules stoutish. A single accessory piece present. Female genital tubes paired, reflexed. Caudal glands and spinneret present.

Hab. Marine.

Genotype : C. attenuatum Cobb, 1920.

Cobb, 1920, Contr. Sci. Nematol., ix, 264 and key.

12. Colpurella Cobb, 1920.

Cuticle finely striated, without lateral alae or bristles. Six lips present. Lateral organs trapezoidal. Buccal capsule long and tubular. Oesophagus with slight posterior swelling. Caudal end of male with five papillate supplementary organs. Testes paired, parallel. Spinneret absent. Female nnknown.

Hab. Fresh water.

Genotype: C. fontinalis Cobb, 1920.

Cobb, 1920, Contr. Sci. Nematol., ix, 257 and key.

13. Cynura Cobb, 1920.

Cuticle without bristles. Lateral alae present. Head with four cephalic bristles. Lateral organs spiral. Buceal capsule narrow and elongate. Oesophagus cylindrical, slightly swollen posteriorly. Male unknown. Female genital tubes paired, opposed, reflexed. Caudal glands and spimneret present.

Hab. Marine.

Genotype: C. uniformis Cobb, 1920.

Cobb, 1920, Contr. Sci. Nematol., ix, 262 and key.

14. Xinema Cobb, 1920.

Cuticle finely striated. Body with papilliform bristles, and without lateral alae. Lateral organs spiral. Head with three lips and four bristles. Pliarymx apparently narrow, tubular. Oesophagus cylindrical, gradually expanding behind. Candal end of male without supplementary organs or special bristles. A pair of jointed spicules, and a pair of accessory pieces, with long posterior processes, present. Testes paired, opposed, outstretched. Female genital tubes paired, opposed, ontstretched, or, occasionally, reflexed at their ends. A pair of "spermathecae" apparently present, extending, when filled, to near the bases of the ovaries. Caudal glands present, near the anus.

Hab. Marine.

Genotype: X. perfectum Cobb, 1920.

Cobb, 1920, Contr. Sci. Nematol., ix, 263 and key. 
15. Halinema Cobb, 1920.

Cuticle with a few short bristles in neck region. Head with ten bristles, four of which are very long. Lateral organs cireular. Buceal capsule short and wide. Oesophagus cylindrieal, very slightly swollen posteriorly. Caudal end of male with preanal supplementary organs. Spicules slender. Two accessory pieces present, with tapering posterior processes. Testes paired, opposed (?). Tail of female with eight pairs of subventral bristles. Female genital tubes paired, the posterior vestigial. Caudal glands and spinneret present.

Hab. Marine.

Genotype: H. spinosum Cobb, 1920.

Cobb, 1920, Contr. Sci. Nematol., ix, 267 and key.

16. Crystallonema Cobb, 1920.

Cuticle with seattered bristles in neck region. Longitudinal fields contain large, doubly-refraetive, crystalline masses. Head with ten bristles, four of which are long and two-jointed. Mouth surrounded by several labial "palps." Lateral organs circular. Buceal capsule short and wide. Oesophagus with a faint, elongate, more or less pyriform posterior swelling. Caudal end of male without supplementary organs or candal bristles. Accessory piece with a posterior process. Testis single, outstretehed. Female genital tubes paired, opposed, but posterior uterine branch vestigial. Ovary outstretched. Spinneret absent.

Hab. Marine.

Genotype : C. simile Cobb, 1920.

Cobb, 1920, Contr. Sci. Nematol., ix, 282 and key.

17. Halanonchus Cobb, 1920.

Cuticle without bristles or lateral alae. Head with three crowns each of six bristles. Lips inconspicuous. Lateral organs circular. Buceal capsule deep and wide, supported by longitudinal ribs. Oesophagus cylindrieal, without bulb. Caudal end of male with fifteen to eighteen inconspicuous supplementary organs. Spicules blunt. A single accessory piece present. Testes paired, opposed, outstretched. Female genital tube single, posterior, outstretched. Spinneret absent.

Hab. Marine.

Genotype : H. macrurus Cobb, 1920.

Cobb, 1920, Contr. Sci. Nematol., ix, 266 and key.

18. Illium Cobb, 1920.

Cuticle fincly striated, without bristles or lateral alae. Head truncate. Ocelli present. Lips inconspicuous. Cephalic 
bristles absent. Lateral organs goblet-shaped. Buccal capsule rather short, prismoid. Oesophagus club-shaped. Male unknown. Female genital tubes paired, opposed, reflexed. Caudal glands and spinneret present.

Hab. Marine.

Genotype : I. exile Cobb, 1920.

Cobb, 1920, Contr. Sci. Nematol., ix, 261 and key.

19. Laimella Cobb, 1920.

Cuticle finely striated, with submedian rows of bristles.* Latcral alae absent. Head romnded, with ten cephalic bristles. Lips not apparent. Lateral organs spiral. Buccal capsule apparently very narrow. An extremely minute tooth present (?). Oesophagus with oval bulb posteriorly. Male unknown. Female genital tubes paired, opposed, ontstretched. Caudal glands and spinneret doubtful.

Hab. Marine.

Genotype: L. longicauda Cobb, 1920.

Cobb, 1920, Contr. Sci. Nematol., ix, 261 and key.

20. Omicronema Cobb, 1920.

Cuticle rather coarsely striated, without bristles. Slight lateral alae present. Head not distinct, with three crowns each of six bristles. Lateral organs circular. Lips inconspicuons. Buccal capsule relatively short and broad. Oesophagus slightly swollen posteriorly. Caudal end of male without supplementary organs. Preanal and postanal submedian bristles present. Spicules slender. A sigmoid accessory piece present. Testis single, ontstretched. Female genital tube single, anterior, outstretched. Caudal glands and spinueret present.

Hab. Marine.

Genotype: O. litorium Cobb, 1920.

Cobb, 1920, Conir. Sci. Nematol., ix, 265 and key.

21. Pseudolella Cobb, 1920.

Cuticle finely striated, without bristles or lateral alae. Head not distinct, with four bristles. Lateral organs long and slender, band-like. Lips indistinct. Buccal capsule long, tubular, slightly expanded posteriorly, apparently with a small ventral tooth at its anterior end. Oesophagus without bulb. Candal end of male without bristles. Spicules acutely pointer. Two accessory pieces present, with blunt posterior processes.

* In the text of Cobb's description the cuticle is also said to be "naked." The bristles are mentioned in connection with the tail, and are there said to occur throughout the body. 
Testes paired, the anterior reflexed, the posterior outstretched. Female genital tubes paired, opposed, outstretched. Caudal glands and spinneret present.

Hab. Marine.

Genotype : P. granulifera Cobb, 1920.

Cobb, 1920, Contr. Sci. Nematol., ix, 268 and key.

22. Rhadinema Cobb, 1920.

Cuticle apparently unstriated, without bristles or alae. Head not distinct, with four bristles. Lateral organs circular. Lips confluent. Buccal capsule minute, shallow and cupshaped, its wall supported by six small longitudinal ribs. Oesophagus slightly swollen posteriorly. Male unknown. Female genital tubes paired, opposed, outstretched. Caudal glands and spinneret present.

Hab. Marine (in sand).

Genotype : $R$. flexile Cobb, 1920.

Cobb, 1920, Contr. Sci. Nematol., ix, 256 and key.

23. Rhynchonema Cobb, 1920.

Cuticle rather coarsely striated, without bristles. Head not distinct, with ten bristles. Lateral organs circular. Lips confluent. Buccal capsule long and tubular. Oesophagus without bulb. Caudal end of male with three minute supplementary organs. Spicules slender. A single accessory piece present. Testis and female genital tube single, anterior, outstretched. Caudal glands and spinneret present.

Hab. Marine.

Genotype : R. cinctum Cobb, 1920.

Cobb, 1920, Contr. Sci. Nematol., ix, 260 and key.

\section{Myctolaimus Cobb, 1920.}

Cuticle faintly striated. No lateral alae or bristles. Head with six large conical lips. Lateral organs absent. Buccal capsule very long, about twice as long as the oesophagus, in two approximately equal parts; the anterior part a simple, narrow tube, the posterior an elongate bulb with triangular lumen. Oesophagus a narrow tube, gradually expanding into a posterior bulb. Tail of male without alae or supplementary organs. Nine pairs of papillae present, of which six are postanal. Spiculcs slender. Two accessory pieces, sigmoid. Testis single, reflexed. Tail of female conically pointed. Female genital tubes paired, opposed, reflexed. Spinneret absent.

Hab. In sheep-dung.

Genotype : M. pellucidus Cobb, 1920.

Cobb, 1920, Contr. Sci. Nematol., ix, 276 and key. 


\section{Plectus Bastian, 1865 .}

Syn. Plectoides de Man, 1904 (as subgenus); Anthonoma Cobb, 1906; Pycnolaimus Cobb, 1920.

Cuticle transversely striated, with scattered fine bristles. Lateral alae present. Head may or may not be distinct, with four or six bristles. Lateral organs elliptical or circular, or semicircular and open behind. Lips, if distinguishable, three or six. Buecal cavity elongate, three-sided. Male of genotype and most other species unknown. When known, the male usually has an accessory piece, preanal and postanal papillae and a single testis. Female genital tubes paired, symmetrical, and short, with a long reflexion. Caudal glands present.

Hab. In moss, roots of plants, moist soil, ete.; also in fresh water.

Genotype: $P$. parietinus Bastian, 1865. (See Stiles and Hassall, 1905, U.S. Dept. Agric., Bur. Anim. Indust. Bull. 79, 103).

Bastian, 1865, Trans. Limn. Soc. London, xxv, 118; Mieoletzky, 1914, Zool. Jahrb., Syst., xxxvi, 454; 1922, Arch.f. Naturg., Abt. A, lxxxvii, 211.

25a. Subgenus Wilsonema Cobb, 1913.

Subgenus of Plectus, according to Micoletzky (1922).

Plectus with the anterior end furnished with lamellar cuticular expansions or processes.

Hab. Soil.

Genotype: W. [Plectus] cephalatum (Cobb, I893).

Cobb, 1893, Nematode Worms found attacking Sugar-cane, N. South Wales Agrie. Dept; 1913, Journ. Washington Acad. Sci., iii, 443 ; Micoletzky, 1922, Arch.f. Naturg., Abt. A, lxxxvii, 241 .

\section{Aplectus Cobb, 1914.}

Cuticle fincly striated. Lateral alae present. Bristles present in the neck region. Lateral organs eircular. Lips very indistinct. Buceal eapsule long, probably in two parts, the anterior part narrow and tubular, the posterior a muscular pharynx. Oesophagus cylindrical, with a small bulb posteriorly. Caudal end of male with three protrusible slipplemen. tary organs and postanal bristles. Spicules rather strong. Two rather strong, slightly bent accessory piees present. Testes paired, opposed, outstretched. Female genital tubes paired, symmetrical, reflexed. Caudal glands and spinneret present.

Hab. Marine.

Genotype: A. antarcticus Cobb, 1914.

Cobb, 1914, Contr. Sci. Nematol., i, 12. 


\section{Haliplectus Cobb, 1913.}

Cuticle finely striated, without bristles. Head truncate, without bristles. Lateral organs circular. Buccal capsule, if present, very narrow. Oesophagus with median and posterior bulbs. Caudal end of male with six supplementary organs. About six pairs of postanal papillae present. An accessory piece present. Testes paired, opposed, outstretched. Female genital tubes paired, opposed, reflexed. Caudal glands and spinncret present.

Hab. Brackish and sometimes fresh water.

Genotype : $H$. pellucidus Cobb, 1913.

Cobb, 1913, Journ. Washington Acad. Sci., iii, 443 and key.

\section{Aulolaimoides Micoletzky, 1917.}

Cuticle unstriated, without bristles or lateral alae. Head not distinct, truncate, without bristles. Lateral organs semicircular, open behind. Buccal capsule narrow, three-sided. Oesophagus with a spindle-shaped median swelling and a somewhat cylindrical posterior bulb. Caudal end of male with preanal and postanal papillae. An accessory piece present. Testis single. Female genital tubes paired, the anterior branch vestigial, both reflexed. No caudal gland or spinneret.

Hab. Mud.

Genotype: A. elegans Micoletzky, 1917.

Micoletzky, 1917, Zool. Jahrb., Syst., xl, 516; 1922, Arch.f. Naturg., Abt. A, lxxxvii, 244.

\section{Bolbonema Cobb, 1920.}

Cuticle finely striated, with bristles. Lateral alae absent. Head somewhat wider than neck. Lips indistinct. Lateral organs spiral. Buccal capsule short and narrow. Oesophagus cylindrical, with pyriform posterior bulb. Male unknown. Tail of female conical. Female genital tubes paired, opposed, reflexed. Caudal glands and spinneret present.

Hab. Marine (in mud).

Genotype: B. brevicolle Cobb, 1920.

Cobb, 1920, Contr. Sci. Nematol., ix, 264 and kcy.

\section{Subfam. 3. BUNONEMINAE Micoletzky, 1922.}

Free-living forms. Body plump, with dorsal or lateral pairs of "warts" or crusty prominences, which are asymmetrical. Cuticle usually with lateral alae. Lateral organs inconspicuous. Head retractile, with large bristles and lamellae. Buccal cavity three-sided. Tail of male with rudimentary "bursa", 
and with papillae. Uterine branches two, reflexed. No caudal glands or spinneret.

1. Bunonema Jägerskiöld, 1905.

Syn. Bogdanowia Zograf, 1913.

Cuticle apparently smooth, except between the rows of warts, where it is finely tessellated or slightly granular. Slight lateral alae typically present. One or two rows of paired "warts," usually lateral. Buccal cavity apparently threesided. Labial structures complex, asymmetrical and apparently protrusible. A variable number of cephalic bristles present. Oesophagus with a true posterior bulb and a slight median swelling. Tail of male with about eight pairs of papillae, three pairs of which are preanal. Two equal spicules and an accessory piece present.

Hab. In moss or rotting wood.

Genotype : B. richtersi Jägerskiöld, 1905.

Jägerskiöld, 1905, Zool. Anz., xxviii, 557; Cobb, 1915, Contr. Sci. Nematol., iii, 101; Zograf, 1913, Zool. Anz., xli, 162.

2. Craspedonema Richters, 1908.

Cuticle with " crust-like" swellings irregularly distributed all over the dorsal surface, but smooth ventrally. Lateral alae well developed, with jagged edges. Head distinct, conical, probably surrounded by six pointed cuticular flaps in front. Buccal cavity three-sided. Oesophagus without median swelling. Male with slender spicules and linear accessory piece.

Hab. In moss.

Genotype: C. javanicum Richters, 1908.

Richters, 1908, Ber. Senckenb. Ges., Frankf. a. M., 23; Steiner, 1916, Zool. Anz., xlvi, 332.

\section{Appendix to Rhabditidae.}

The following genera are referred to the family with some uncertainty, and owing to the present rather unsatisfactory characterization of the subfamilies Rhabditinae and Cylindrolaiminae, we do not attempt to refer these doubtful genera to either group.

a. Zalonema Cobb, 1920.

Cuticle finely striated, without bristles or lateral alae. Head not distinct, with four bristles (?). Lateral organs spiral. Pharynx tubular, sinuous, with two prominent irregularities of its wall, one dorsal and one ventral. Oesophagus cylindrical, with broad pyriform posterior bulb. Caudal end of male with preanal alae, but without supplementary organs. 
Two accessory pieces present. Testis apparently single, anterior, outstretched. Female genital tubes paired, opposed, reflexed. Caudal glands and spinneret present.

Hab. Marine.

Genotype: Z. nudum Cobb, 1920.

Cobb, 1920, Contr. Sci. Nematol., ix, 272 and key.

b. Monhystrium Cobb, 1920.

Cuticle unstriated, without bristles or lateral alae. Head not distinct, with ten short bristles. Lips three, more or less fused. Lateral organs small, circular. Buccal capsule very much reduced, funnel-shaped. Oesophagus with a pyriform posterior bulb. Caudal end of male without supplementary organs, but with several pairs of postanal papillae. Testis single, anterior, outstretched. Female genital tubes paired, opposed, the posterior branch vestigial.

Hab. Gill-chambers of Land-crabs.

Genotype: M. transitans Cobb, 1920.

Cobb, 1920, Contr. Sci. Nematol., ix, 284 and key.

\section{c. Tripylium Cobb, 1920 .}

Cuticle smooth, without bristles or alae. Head not distinct, with six papilliform bristles and six labial papillae. Lateral organs incipient spirals. Pharynx wide, thick-walled, forming anteriorly three jaw-like inward projections on the inner surfaces of the lips. Oesophagus cylindroid, with a distinct bulb-like swelling posteriorly. Tail of male with three pairs of inconspicuous subventral papillae. Spicules slender. A slender accessory piece present. Testis single, reflexed at extreme end. Female genital tube single, anterior, outstretched. Viviparous. Caudal glands and spinneret present.

Hab. Gill-chambers of Land-crabs.

Genotype : T. [Monhystera] carcinicola (Baylis, 1915).

Baylis, 1915, Ann. Mag. Nat. Hist., (8) xvi, 418; Cobb, 1920, Contr. Sci. Nematol., ix, 288 and key.

There are some discrepancies between the original description of "Monhystera" carcinicola and Cobb's account of Tripylium carcinicolum, but the material upon which both were based appears to have come from the same source, and presumably the species is the same. According to the original description, there was evidence that $M$. carcinicola was a protandrous hermaphrodite. The systematic position of Tripylium is difficult to determine. Its habits and general organization suggest that it should be placed near Monhystrium, which is here regarded as possibly belonging to the Rhabditidae. The presence of the three jaw-like structures 
at the entrance to the pharynx might, however, be taken to indieate relationship with the Oncholaimidae, and it would be possible to include the genus in the subfamily Ironinae.

d. Leptodera Dujardin, 1845.

Syn. Alloionema Schneider, 1859; Alloeonema Lenckart, 1863.

Body fusiform, tapering finely at both extremities. Mouth with bilobed (?) border. A tubular buceal cavity present. Oesophagus with a large posterior club-shaped swelling. Caudal end of male with short alae supported by five or six pairs of elongate papillae. Behind the alae the tail tapers to a fine filament. Spicules equal, strongly curved, broad at the roots. A small accessory piece present. Testis ontstretched. Vulva in the middle of the body. Female genital tubes apparently opposed, outstretched. Viviparous.

Hab. Genotype in the vas deferens of a slng. Other species found in soil, decaying substances, etc., have been referred to the genus.

Genotype: L. flexilis Dujardin, 1845.

Dujardin, 1845, Histoire nat. des Helminthes, Paris, 108; Schneider, 1866, Monographie der Nematoden, Berlin, 154.

\section{e. Streptogaster Cobb, 1898.}

Head not distinct. Lips obscure. Buccal capsule cylindrical, apparently with four (?) supporting rods in its wall, each having a small tooth at about its middle. Oesophagus proper long and cylindrical, followed by a pyriform posterior bulb with a short, narrow neck. Tail of male conical. Apparently a single spicule and two aceessory pieces present. Several pairs of preanal and postanal papillae present. Testis single, anterior, reflexed. Female not deseribed.

Hab. Not mentioned (presumably free-living).

Genotype: S. papillatus Cobb, 1898.

Cobb, 1898, Agric. Gaz. N.S.W., Sydney, ix, 320.

We have endeavoured to extract sufficient characters for a generic diagnosis from the figures of the male given by Cobb. The only description available is contained in the legend to these figures, and the formula. It appears unlikely that the genus can be recognized by means of the data available.

f. Walcherenia de Nan, 1921.

Cuticle striated, apparently without bristles or lateral alae. Head with bristles. Lateral organs unknown. Buccal capsule cylindrieal, suddenly constrieted behind. Ocsophagus 
with a posterior bulb. Male unknown. Female genital tube single, anterior. Caudal glands absent.

Hab. Sand, near coast.

Genotype: W. typica de Man, 1921.

de Man, 1921, Capit. Zool., i, 14.

This diagnosis is based on a single immature female.

g. Terschellingia de Man, 1888.

Cuticle unstriated, with a few small bristles anteriorly. Head distinet, without lips, but with small bristles. Buecal eapsule very small. Oesophagus extremely short, with a large posterior bulb having a dilated lumen. Caudal end of male without papillae. Spicules short. An accessory piece, with two posterior processes, present. Female genital tubes paired, opposed. Caudal glands and spinneret present.

Hab. Marine.

Genotype : T. communis de Man, 1888.

de Man, 1888, Mém. Soc. Zool. France, i, 11 ; Micoletzky, 1922, Arch.f. Naturg., Abt. A, lxxxvii, 183.

gg. Subgenus Oligomonohystera Micoletzky, 1922.

(Subgenus of Terschellingia.) *

Lateral organs circular or slit-like. Buccal eapsule small and typical, or spaeious. Female genital tubes paired, opposed.

Hab. Marine and terricolous.

Type: T'erschellingia (O.) [Monhystera] elongata (Bütschli, 1874).

Bütschli, 1874, Abhandl. Senckenb. naturf. Ges., Frankfurt a. M., ix, 262 ; Micoletzky, 1922, Arch.f. Naturg., Ixxxvii, 168.

\section{h. Chronogaster Cobb, 1913.}

Cuticle finely striated, without bristles or alae. Head not distinet, with four bristles. Lateral organs trapezoid, open behind. Buccal capsule fumnel-shaped. Oesophagus with a posterior bulb. Caudal end of male with nine protrusible preanal supplementary organs. Testes paired, opposed, outstretched. Female genital tube single, anterior, reflexed. Caudal glands and spinneret present.

Hab. Fresh water.

Genotype: C. gracilis Cobb, 1913.

Cobb, 1913, Journ. Washington Acad. Sci., iii, 443 and key.

* Oligomonohystera was proposed by Micoletzky (1922) as a subgenus of Monhystera. The only character serving to distinguish it from Monhystera s.s. is the fact that the female genital tubes are paired. We consider that this character excludes it from that genus, and suggests its inclusion in the genus Terschellingia. 


\section{i. Dasynema Cobb, 1920.}

Cuticle very coarsely striated, without bristles, but with eight longitudinal alae. Head with two crowns of bristles. I ips three, each armed at the summit with a short internal tooth. Lateral organs spiral. Buccal cavity rather narrow. Oesophagus with a median club-shaped swelling and a distinct posterior bulb. Candal glands and spinneret prescnt. Description based on a single immature spceimen, apparently of unknown sex.

Hab. Marine.

Genotype: D. sexalineatum Cobb, 1920.

Cobb, 1920, Contr. Sci. Nematol., ix, 253 and key.

\section{j. Halaphanolaimus Sonthern, 1914.}

Cuticle coarsely striated. Head separated from body by a circular groove, and with four submedian bristles. Lateral organs spiral. Neck with " chitinous gland-ducts," three in male, two in female, on ventral surface. A narrow buccal eapsule present. Oesophagus with a posterior bulb. Caudal end of male apparently with preanal supplementary organs. 'Two simple accessory pieces present. Testes paired, parallel. Female genital tubes paired, symmetrical. Caudal glands present.

Hab. Marine.

Genotype: H. pellucidus Southern, 1914.

Southern, 1914, Proc. R. Irish Acad., xxxi, 11.

k. Antomicron Cobb, 1920.

Syn. Eutelolaimus de Man, 1922.

Cutiele coarsely striated, without bristles. Lateral alae present. Head with bristles. Lateral organs each consisting of two concentric ellipses. Buccal capsule very minute, conoid. Oesophagus expanding in micldle and with a small, elongate, posterior bulb. Caudal end of male with eight preanal, protrusible supplementary organs. Preanal and postanal bristles present. Accessory piece present. Testes paired, opposed; the anterior ontstretched, the posterior reflexed. Female genital tubes paired, symmetrical, reflexed. Candal glands present.

Hab. Marine.

Genotype: A. pellucidum Cobb, 1920.

Cobb, 1920, Contr. Sci. Nematol., ix, 241 and key; de Man, 1922, Tijdschr. Ned. Dierk. Ver., xviii, 126.

de Man, in describing Eutelolaimus, from females only, suggests that this genus is probably identical with Antomicron Cobb, of which the male only has been described. 
1. Laxonema Cobb, 1920.

Cuticle coarsely striated, with irregularly-distributed bristles, and without lateral alae. Cuticle of head radially striated, with four bristles and a double erown of papillae. Lateral organs tubular, open in front. Bueeal capsule very small. Oesophagus with pyriform posterior bulb. Caudal end of male with minute longitudinal striations, without supplementary organs or caudal papillae. Spieules rather stout. An accessory piece present. Testis single, outstretched. Candal glands and spinneret present. Female unknown.

Hab. Marine.

Genotype: L. majum Cobb, 1920 [rectius majus].

Cobb, 1920, Contr. Sci. Nematol., ix, 243 and key.

m. Pararhabditis, nom. nov.

Syn. Pseudorhabditis Szüts, 1912, nec Perroncito, 1880.

Body tapering towards each end. Head "pointed in the manner of a ninepin," with three naked lips. Cuticle longitudinally striated. Anterior portion of body covered thickly with curved, backwardly-directed spines, extending in constantly thinning rows to the middle of the body. Buecal cavity tubular, wide. Oesophagus with an oval median and a club-shaped posterior bulb. Vulva in posterior region of body. Female genital tubes symmetrical.

Hab. Parasitic in an Earthworm.

Genotype : P. [Pseudorhabditis] entzi Szüts, 1912.

Szüts, 1912, Allatt. Közlem., Budapest, xi, 82.

\section{Fam. 8. MERMITHIDAE Braun, 1883.}

Greatly elongate and generally relatively slender forms (in the adult eondition), with a smooth cuticle, frequently containing spiral fibres which run through it in eriss-cross directions. Head usually with two lateral and four submedian papillae, and often with additional small circumoral papillae. A pair of lateral organs always present, usually well developed. Alimentary eanal complete only in the larvae. In the early larval stage the mouth is provided with a piereing stylet, which is lost after penetration into the host. In the adults the oesophagus becomes reduced to a simple, narrow, euticular tube, and the intestine becomes modified into a sausageshaped, solid fat-body, without an anal opening. Genital tubes usually paired in both sexes. Caudal end of male without alae, but usually with three longitudinal rows of papillae. A pair of spicules or a single spicule present. Vulva at about the middle of the body. Vagina short and muscular, 
frequently bent $\mathrm{S}$-wise. Uterine branches opposed. Oviparous.

Hab. Adults, in soil or fresh water. Larvae, at first in soil or fresh water, afterwards becoming parasitie (until nearly full grown) in body-eavity of Arthropods (ehiefly inseets) or Mollusca.

\section{Mermis Dujardin, 1842.}

For synonyms see discussion below.

With the characters of the family.

Genotype: M. nigrescens Dujardin, 1842.

Dujardin, 1842, Compt. rend. Acad. Sci., Paris, xv, 117 ; Hagmeier, 1912, Zool. Jahrb., Syst., xxxii, 521 ; Dadlay, 1913, Math.-natw. Ber. Ungarn, Leipzig, xxvii, 214; Cobb, in Ward and Whipple, 1918, Fresh-water Biology; Steiner, 1923, Journ. Hered., Washington, xiv, 147.

Attempts have been made to split up Mermis into a considerable number of genera. The characters available for this purpose are very slight and do not appear to be of suffieient importance to justify the erection of genera. Purely for the sake of convenience, it might be useful to retain the various names proposed as subgenera, but even this appears to us somewhat mmecessary at present. 'The following key, which is taken in a modified form from Cobb's artiele on the Mermithidae in Ward and Whipple's Fresh-water Biology (1918), indieates the nature of the classification adopted by some recent authors. To the genera included in the key must be added Agamermis Cohb, Steiner and Christie, 1923 (Journ. Agric. Res., Washington, xxiii, 926), the only important eharacter of which is that the parasitic larva, on entering its host, sheds a large portion of its body at a preformed " node." Some further genera have been still more recently proposed.

I. Subcuticula with only two longitudinal ficlds.

Cuticle with criss-cross fibres.

Spicules paired . . . . Neomermis v. Linstow, 1904.

II. Subcuticula with more than two longitudinal fields.

A. Longitudinal fields six.

A. Cuticle without criss-cross fibres.

a. spicules paired. . . Mesomermis Daday, 1911.

b. spicule single.

a. Vagina of adult S-sliaped

Limnomermis Daday, 1911.

$\beta$. Vagina of adult not $\mathbf{S}$-shaped

Pseudomermis de Man, 1903.

в. Cuticle with criss-cross fibres.

$a$. Vagina of adult S-shaped.

a. spicule single. Paramermis v. Linstow, 1898.

B. spicules paired. .Mermis Dujardin, 1842.

b. Vagina of adult not S-shaped

Bathymermis Daday, 1911. 
B. Longitudinal fields eight.

a. Cuticlo without criss-cross fibres

b. Cuticle with eriss-cross fibres

Hydromermis Corti, 1902.

Eumermis Daday, 1911.

On the whole, we are inclined to the view that all these names should be regarded for the present as synonyms of Mermis, together with several others not included in the key, such as Autoplectus Balsamo-Crivelli, 1843, Spinifer v. Linstow, 1901 (Jena. Zeitschr., $\mathrm{xxxv}, 418$ ), Tetradonema Cobb, 1919 (Journ. Parasitol., v, 185), Aproctonema Keilin, 1917 (Compt. rend.Acad.Sci., Paris, clxv, 399), and Gastromermis Micoletsky, 1923 (Zool. Anz., lv, 243). The last was proposed as a subgenus of Paramermis. Agamomermis Stiles, 1903, is not a generic name, but a collective name for immature Mermithidae.

Fam. 9. ANGUILLULINIDAE nov.

Syn. Tylenchidae Micoletzky, 1922.

Small, free-living, semi-parasitic or parasitic forms. Pharynx in the adult modified into a protrusible stylet or "spear." Oesophagus simple or with a median and a posterior bulb-like swelling. When two swellings are present, only the anterior of them is a muscular bulb. Caudal glands and spinneret usually absent.

Micoletzky (1922) divides the family Tylenchidae into three subfamilies (Diphtherophorinae, Dorylaiminae and Tylenchinae), basing his classification chiefly upon the structure of the stylet, which may be more or less evidently formed of three separate rods, and may show more or less obvious traces of three posterior knobs, one belonging to each of the rods. This system does not, however, appear to offer a natural classification of the group, and it seems to us that a somewhat more satisfactory subdivision is arrived at by considering primarily the characters of the oesophagus. There are two main types of oesophageal structure in the family, and if the genera be arranged in two groups according to the form of the oesophagus, it is possible to regard these as two subfamilies for which the comparatively well-known genera Anguillutina and Dorylaimus may stand as types.

\section{Subfam. 1. ANGUILLULININAE nov.}

Oesophagus with a median muscular bulb and a posterior non-muscular swelling, the latter sometimes not distinctly separated from the intestine.

1. Anguillulina Gervais \& van Beneden, 1859.

Syn. Anguina Scopoli, 1777; Tylelenchus Bastian, 1865; Tylenchus Bastian, 1865; Eutylenchus Cobb, 1913; Atylenchus SYN. NEM. 
Cobb, 1913; Tylenchorhynchus Cobb, 1913; Dolichodorus Cobb, 1914; Iotonchium Cobb, 1920; Aphelenchulus Cobb, 1920; Parasitylenchus Nicoletzky, 1922; Paratylenchus Micoletzky, 1922; Chitinotylenchus Micoletzky, 1922.

Cuticle striated, without bristles. Lateral alae often present. Head usually not distinct, usually without lips, papillae or bristles. Lateral organs unknown. Stylet consists of three rods fused throughout, with distinet knobs posteriorly. Caudal end of male usually with alae. One or two accessory pieces generally present. Testis single. Female genital tubes paired, opposed; the posterior may be rudimentary and without ovary. Caudal glands and spinneret absent.

Hab. Chiefly soil, especially on roots of plants. Some species occur in fresh water or decaying substances, or even in the sea. Many are plant-parasites, a few parasites or semiparasites of insects.

Genotype: A. [Vibrio] tritici (Steinbuch, 1799) (by page precedence).

Gervais \& van Beneden, 1859, Zoologie Médicale, Paris, ii, 101 ; Bastian, 1865, Trans. Linn. Soc. London, xxv (2), 125; Micoletzly, 1922, Arch.f. Naturg., Abt. A, lxxxvii, 542.

Micoletzky (1922) proposes to divide Tylenchus into two subgenera, Tylenchus s.s. and Chitinotylenchus. The latter apparently has as its type $T$. paragracilis Micoletzky, 1922, and is characterized by the presence, on the anterior end of the body, of a more or less complex chitinoid investment. The value of this distinction appearing somewhat doubtful, we prefer to regard Chitinotylenchus, for the present, as a synonym. A number of other names included in the synonymy have been proposed for forms which apparently differ only in unimportant details from the type of Anguillulina. Paratylenchus was based on a single female specimen. Parasitylenchus was proposed for the reception of two species which are said to have a free-living generation and a generation parasitic in beetles. These forms have, in the free-living generation, a poorly-developed median oesophageal bulb, and the caudal alae of the male are slight or absent. Consiclered as generic differences from Anguillulina these characters are very indefinite, and we have therefore treated Parasitylenchus as a synonym.

\section{Tylenchulus Cobb, 1913.}

In most respects this genus agrees with Anguillulina, ${ }^{*}$ from which it is said to differ in the following characters: (1) There

* In some respects, and especially in the swelling of the body of the female, Tylencludus seems even more closely related to Heterodera (see below, p. 67). From this genus, however, it differs in having only a single female genital tube, in the absence of an anus, and in the fact that the vulva is not quite terminal. 
is no functional anus. (2) The excretory pore is near the middle of the body. (3) The male has no caudal alae. (4) The male "practically loses the spear at the final moult." (5) The posterior portion of the body of the female becomes sac-like at maturity, and its cuticle much thickencd. (6) The vulva is situated in a deep "suture."

Hab. Parasitic on the roots of Citrus trees.

Genotype: T. semi-penetrans Cobb, 1913.

Cobb, 1913, Journ. Washington Acad. Sci., iii, 2ss; 1914, Journ. Agric. Res., Washington, ii, 217.

\section{Aphelenchus Bastian, 1865.}

Syn. Paraphelenchus Micoletzky, 1922; Chitinoaphelenchus Micoletzky, 1922.

Cuticle usually striated, without bristles. Lateral alae sometimes well developed. Head usually distinct, knob-like, without lips or bristles. Cephalic papillae rarely distinct. Lateral organs unknown. Stylet composed of three fused rods, not always distinctly knobbed behind. Caudal end of male without alae, usually with postanal papillae and sometimes with preanal papillae. Spicules slender. A slight accessory piece often present, sometimes composed of three fused pieces, two dorsal and one ventral, and usually with an expanded, handle-like inner end. Female genital tubes typically paired, opposed, outstretched, but with posterior branch of uterus vestigial and without ovary. Spinneret apparently absent.

Hab. Chiefly in soil, about roots of plants. Some species in fresh water, in decaying substances, or parasitic on plants.

Genotype : A. avenae Bastian, 1865.

Bastian, 1865, Trans. Linn. Soc. London, xxv, 93, 121 ; Micoletzky, 1922, Arch.f. Naturg., Abt. A, Ixxxvii, 584.

Micoletzky (1922) proposes to divide this genus into three subgenera, Aphelenchus, Paraphelenchus and Chitinoaphelenchus. Paraphelenchus is intended to contain three species in which the oesophagus is marked off from the intestine more distinctly than in typical forms, while Chitinoaphelenchus contains only two species, characterized by "chitinous ornamentation " of the anterior end. These peculiarities are so slight that they scarcely seem to warrant the erection of special subgenera. The distinctions between Aphelenchus and Anguillulina do not appear to be very definite.

4. Heterodera Schmidt, 1871.

Syn. Meloidogyne Göldi, 1889; Heterobolbus Railliet, 1896 ; Caconema Cobb, 1924. 
Male of typical cylindrical shape. Body of mature female becomes swollen into an ovoid or subspherical shape, only the neek region remaining normal. The tail disappears, its place being taken by a terminal prominenee earrying the vulva, and the anus becomes dorsal in position. Cuticle striated, without bristles. Head rather distinet, with six lips. Lateral organs ineonspieuous or absent. Stylet eomposed of three rods, fused throughout and knobbed behind. Candal end of male without alae or papillae. Spicules equal, short and broad. No accessory piece. Testis, in genotype, single, anterior, outstretehed. Female genital tubes paired, parallel, anterior, elongate and sinuous. Oviparous, but eggs remaining in the uterus after the death of the female hatch there and the larvae eseape later. Exeretory system a lateral canal on the left side only.

Hab. Parasitic on roots of plants.

Genotype: H. schachtii Schmidt, 1871.

Sehmidt, 1871, Zeitschr.d.Ver.f. Rüben-Indust. in Zollverein, xxi, 1-19 (not verified); Strubell, 1888, Bibliotheca Zool., Cassel, i (2), 1-50; Railliet, 1896, Réc. Méd. vét., Paris, lxxiii, 161; Mareinowski, 1909, Arb. k. Biol. Anst. f. Landu. Forstwirtsch., Berlin, vii, 147; Cobb, 1924, Journ. Parasitol., xi, 118, 120.

The name Heterobolbus was proposed by Railliet to replace Heterodera, on the ground that the name Heteroderes had previously been used by Latreille for another animal. 'This, however, does not seem to be a suffieient reason for abolishing Heterodera. The name Caconema has been proposed by Cobb for Heterodera radicicola (Greeff), but the author expresses uncertainty as to whether it should be regarded as a distinct genus or as a subgenus of Heterodera. The characters in whieh it is said to differ from Heterodera s.s. are that it is "truly endoparasitie and less specialized in its parasitism; having the amphids proteeted by 'cheeks '; the males with two testes, instead of one as in H. schachtii."

\section{Nemonchus Cobb, 1913.}

Cuticle finely striated, without bristles. Head not distinct, without lips, papillae or bristles, but "helmeted" (presumably with a speeialized external euticular eap). Lateral organs unknown. Stylet relatively massive, in two portions, the posterior much thicker than the anterior but not so well chitinized, with knobbed base. Caudal end of male without supplementary organs or papillae. Testes paired, parallel, anterior, outstretched. Female genital tubes paired, opposed, outstretched. 
Hab. Soil ( ?).

Genotype : N. galeatus Cobb, 1913.

Cobb, 1913, Journ. Washington Acad. Sci., iii, 434.

6. Hoplolaimus Daday, 1905.

Syn. Iota Cobb, 1913; Criconema (also Krikonema) Hofmänner and Menzel, 1914; Ogma Southern, 1914.

Cuticle with wide, often prominent annulations, sometimes forming series of "scales" or spines, but without bristles. Lateral alae absent. Head sometimes distinct. Lips usually poorly developed. Six cephalic papillae or bristles may be present. Lateral organs unknown. Stylet very long, more or less obviously formed of three rods, and knobbed behind. Stylet of male appears to be lost at the last moult. Male (known only in $H$. [Iota] squamosus) with two spicules, without accessory piece or caudal papillae, and with single, anterior, outstretched testis. Female genital tube single, anterior, outstretched, or paired, opposed, outstretched. Oviparous. Probably usually hermaphrodite. Caudal glands and spinneret absent. Anus sometimes absent in female.

Hab. Fresh water or soil.

Genotype: H. tylenchiformis Daday, 1905.

Daday, 1905, Zoologica, Stuttgart, xviii, 62; Cobb, 1913, Journ. Washington Acad. Sci., iii, 434, 437; Hofmänner and Menzel, 1914, Zool. Anz., xliv, 88; Menzel, 1917, Rev. suisse Zool., Xxv, 153; Micoletzky, 1922, Arch. f. Naturg., Abt. A, lxxxvii, 577.

\section{Psilenchus de Man, 1921.}

Cuticle striated, without bristles. Head slightly distinct, rounded, without lips, papillae or bristles. Lateral organs transversely elliptical, situated far forward. Stylet slender, hollow, not knobbed behind. Caudal end of male with alae, without papillae. An accessory piece present. Female genital tubes paired, symmetrical, outstretched. Caudal glands probably absent.

Hab. Soil.

Genotype: P. hilarulus de Man, 1921. de Man, 1921, Capit. Zool., i, 36.

\section{Isonchus Cobb, 1913.}

Cuticle finely striated, without bristles or alae. Head not distinct, without lips or bristles. Lateral organs unknown. Stylet long, not knobbed at base. Caudal end of male with alae, with four pairs of ray-like papillae. Four pairs of smaller papillae also present. An accessory piece present. 'Testis and female genital tube single, anterior, outstretched. Caudal glands absent. 
Hab. Soil.

Genotype: I. radicicolus Cobb, 1913.

Cobb, 1913, Journ. Washington Acad. Sci, iii, 434, 439; Micoletzky, 1922, Arch.f. Naturg., Abt. A, lxxxvii, 541.

\section{Tylopharynx de Man, 1876.}

Cuticle with fine transverse striations and with longitudinal striations, withont bristles. Head slightly distinet, knob-like, withont lips, papillae or bristles. Lateral organs unknown. Stylet consists of three rods, fused anteriorly and knobbed posteriorly. Caudal end of male with numerous subventral preanal and postanal papillae. An accessory piece present. Female genital tubes paired, opposed, reflexed. Caudal glands absent.

Hab. Soil.

Genotype: T. striata de Man, 1876.

de Man, 1876, Tijdschr. Ned. dierk. Vereen., ii, 116; 1884, Die frei... lebenden Nematoden d. Niederl. Fauna, 131; Micoletzky, 1922, Arch.f. Naturg., Abt. A, lxxxvii, 432.

\section{Subfam. 2. DORYLAIMINAE nov.}

Oesophagus without median bulb, but usually with a more or less distinct posterior swelling, which sometimes forms a bulb.

1. Dorylaimus Dujardin, 1845.

Syn. Antholaimus Cobb, 1913; Nygolaimus Cobb, 1913; Actinolaimus Cobb, 1913; Discolaimus Cobb, 1913; Dorylaimellus Cobb, 1913; Axonchium Cobb, 1920; Doryllium Cobb, 1920 ; Longidorus Micoletzky, 1922.

Cuticle usually unstriated, without lateral alae or bristles. Head separated by a constriction from body, usually with six lips, each bearing two papillae, but without bristles. Lateral organs inconspicuous, probably usually slit-like. Stylet tubular, not knobbed behind. Oesophagus swollen behind, but without distinet bulb. Caudal end of male with a median row of preanal papillae. Postanal papillae present in both sexes. Spicules fairly stout. Two rod-like accessory pieces usually present, elosely applied to the spicules. Testes paired, opposed, outstretched. Female genital tubes almost always paired, opposed, reflexed; occasionally single, posterior. Caudal glands and spinneret absent.

Hab. Soil, fresh water, on plants or in decaying substances.

Genotype: probably D. stagnalis Dujardin, 1845, according to Stiles \& Hassall (1905).

Dujardin, 1845, Hist. nat. des Helminthes, Paris, 230; Cobb, 
1913, Journ. Washington Acad. Sci., iii, 432-444; 1920, Contr. Sci. Nematol., ix, 303, 305; Micoletzky, 1922, Arch.f. Naturg., Abt. A, lxxxvii, 434, 535.

Antholaimus and Nygolaimus are regarded, probably rightly, by Micoletzky (1922) as synonyms of Dorylaimus. Actinolaimus, according to Cobb (1918, in Ward and Whipple, Freshwater Biology, 485), was "proposed for species similar to Dorylaimus labyrinthostomus, in which the pharynx is more or less immobile, radially striated and elaborately constructed." According to Micoletzky, Actinolaimus differs from Dorylaimus only in having a very large "vestibule " with thick, chitinized walls. This character, however, is evidently subject to some variation, and its generic value seems questionable. We have also included in the synonymy five other names proposed for forms showing slight peculiarities in the form of the stylet or of the oesophagus, which have been treated by Micoletzky as subgencra of Dorylaimus.

\section{Trichodorus * Cobb, 1913.}

Syn. Leptonchus Cobb, 1920.

This genus apparently very closely resembles Dorylaimus, from which it differs chiefly in the following characters:Lateral organs stirrup-shaped. Stylet very long, asymmetrical, bent dorsally, with a cap-like chitinoid structure anteriorly. Testis single, outstretched.

Hab. Soil.

Genotype : T. [Dorylaimus] primitivus (de Man, 1884) (=T. obtusus Cobb, 1913).

de Man, 1884, Die frei . . lebenden Nematoden d. Niederl. Fauna, 162; Cobb, 1913, Journ. Washington Acad. Sci., iii, 434, 441; 1920, Contr. Sci. Nematol., ix, 304; Micoletzky, 1922, Arch.f. Naturg., Abt. A, lxxxvii, 539.

\section{Campydora Cobb, 1920.}

Cuticle unstriated, without bristles, with eight longitudinal striations, becoming more marked and almost like alae in the ncck region. Head truncate, with six lips and two crowns of six and twelve papillae respectively. Lateral organs elliptical. Stylet bent dorsally in front, its base not knobbed. Oesophagus expands suddenly behind into a distinct cylindrical bulb. Male unknown. Female genital tube single, anterior, reflexed. Spinneret absent.

Hab. Soil.

Genotype : C. demonstrans Cobb, 1920.

* Cobb (1913) uses the name Trichodora in the key at p. 434, changing it to Trichodorus on p. 441. 
Cobb, 1920, Contr. Sci. Nematol., ix, 307 and key; Micoletzky, 1922, Arch.f. Naturg., Abt. A, lxxxvii, 541.

4. Onchium Cobb, 1920.

Cutiele thin, very finely striated, without bristles. Head not distinet, with four bristles. Lateral organs incipient spirals, situated far forward. Stylet very short, hollow, not linobbed behind. Oesophagus eylindroid, not distinet from intestine (with posterior swelling, aceording to key). A pair of oeelli present. Male unknown. Female genital tube single, anterior, reflexed. Spinneret present.

Hab. Marine (in sand).

Genotype : O. ocellatum Cobb, 1920.

Cobb, 1920, Contr. Sci. Nematol., ix, 303 and key.

5. Onchulella Cobb, 1920.

Cuticle extremely finely striated, without bristles. Head not distinet, without lips or papillae, but with four bristles. Lateral organs incipient spirals, situated far forward. Stylet apparently solid, not knobbed behind. Oesophagus eylindroid anteriorly, "the posterior part more or less obscure." A pair of oeelli present, with lenses. Oesophageal region eontains numerous elongate glands. Male unknown. Female genital tubes paired, opposed, reflexed. Caudal glands present.

Hab. Marine.

Genotype : O. ocellata Cobb, 1920.

Cobb, 1920, Contr. Sci. Nematol., ix, 306 and key.

6. Triplonchium Cobb, 1920.

Cuticle unstriated, without bristles. Head not distinet, slightly eonical, with six papillae. Lateral organs tubular, protrusible. Stylet short, slender, knobbed behind. Oesophagus eylindroid, with pyriform posterior bulb. Candal end of male apparently with one or two inconspienous preanal papillae. Spieules short and stout. "There are very obscure, straight aecessory pieees." (Aceording to the figures, the aecessory pieces are a pair of peeuliar ring-like structures, with a diameter nearly equal to the length of the spicules). Testis single, anterior, outstretehed. Female with single uterus, running posteriorly from the vulva, then turning anteriorly. Ovaries paired, opposed, reflexed. Eggs few. Tail in both sexes short and blunt. Spinneret absent.

Hab. Soil.

Genotype: T. cylindricum Cobb, 1920.

Cobb, 1920, Contr. Sci. Nematol., ix, 300 and key. 
7. Diphtherophora de Man, 1880.

Syn. Chaolaimus Cobb, 1893; Archionchus Cobb, 1913.

Cuticle unstriated, without bristles or alae. Head without lips or bristles, but with papillae. Lateral organs slit-like or transversely elliptical. Stylet consists of three straight rods, each knobbed behind, one ("ventral ") shorter than the others (" dorsal "), apparently connected anteriorly with a triangular chitinoid cap. Oesophagus swollen behind, but without posterior bulb. Caudal end of male with one or two median preanal papillae. Accessory piece absent. Female genital tubes paired, opposed.* Caudal glands absent (?).

Hab. Soil.

Genotype : D. communis de Man, 1880.

de Man, 1880, Tijdschr. Ned. dierk. Vereen., Leiden, v, 62; 1884, Die frei . . lebenden Nematoden d. Niederl. Fauna, 128; Cobb, 1893, Agric. Gaz. N.S.W., iv, 821; 1913, Journ. Washington Acad. Sci., iii, 438; Micoletzky, 1922, Arch. $f$. Naturg., Abt. A, lxxxvii, 421.

\section{Tylencholaimus de Man, 1876.}

Syn. Xiphinema Cobb, 1913.

Cuticle externally unstriated, without alae or bristles. Head usually distinct, without lips or bristles but with a crown of papillae. Lateral organs stirrup-shaped. Stylet consists of three rods, fused anteriorly and knobbed posteriorly. Oesophagus swollen posteriorly, occasionally with a bulb. Caudal end of male with a few median preanal papillae. Spicules stout, with a midrib. Accessory piece absent, or two accessory pieces present, closely applied to the spicules. Testis usually single, occasionally paired, opposed, outstretched. Female genital tube usually single, anterior or posterior; sometimes paired, opposed, reflexed. Caudal glands and spinneret absent.

Hab. Soil or fresh water.

Genotypc : T. [Tylenchus] mirabilis (Bütschli, 1873).

Bütschli, 1873, Nov. Act.k. Leop.-Car. Akad. Naturf., Dresdell, xxxvi, 44; de Man, 1876, Tijdschr. Ned. dierk. Vereen., ii, 119 ; 1884, Die frei . . . lebenden Nematoden d. Niederl. Fauna, 132 ; Micoletzky, 1922, Arch.f. Naturg., Abt. A, lxxxvii, 423.

* In Chaolaimus, according to Cobb (1893), the female genital tube is apparently single, anterior and reflexed, passing back beyond the vulva and extending half-way to the anus. His description, however, seems to have been based on an inmature and moulting specimen. 


\section{Brachynema Cobb, 1893, nec Fieb., 1861.*}

The type of this genus (which is based on a single immature speeimen) appears to have possessed very generalized larval charaeters, and may possibly have belonged to some genus of Anguillulinidae whose adult eharacters are better known. In general it approaches perhaps most nearly to Tylencholaimus, but it is impossible to assign it definitely to this or to any other genus.

Hab. Soil.

Genotype : B. obtusa Cobb, 1893.

Cobb, 1893, Agric. Gaz. N.S.HY., iv, 811.

\section{Tylencholaimellus M. V. Cobb, 1915.}

Cuticle very finely transversely striated, and with longitudinal striations, without bristles. Head not distinct, with six low papillae, and apparently also less conspicuous eireumoral papillae. No eephalie bristles. Stylet short, obliquely truncate anteriorly, with stouter posterior portion, knobbed at its base. A separate chitinoid piece, directed slightly outwards, lies dorsally to the stylet. Oesophagus with an elongate posterior bulb. Caudal end of male with two preanal papillae. No postanal papillae or bristles. Spicules slender. No accessory piece. Testes paired, opposed, outstretched. Female unknown.

Hab. Fresh water.

Genotype: T. diplodorus M. V. Cobb, 1915.

M. V. Cobb, 1915, Trans. Amer. Hicr. Soc., xxxiv, 28; Micoletzky, 1922, Arch.f. Naturg., Abt. A, Ixxxvii, 431.

\section{Tylolaimophorus de Man, 1880 .}

Cuticle with fine transverse striations, without alae or bristles. Head not distinct, rounded, without bristles, but with a crown of small rod-like circumoral papillae and a seeond erown of conical papillae. Lateral organs transversely oval, situated far forward. Stylet consists of three rods, joined anteriorly and with a chitinoid cap apparently composed of three short, curved rods. Oesophagus narrow, non-museular, with bulb-like posterior swelling. Intestine with a postanal eaecum. Male unknown. Female genital tubes paired, opposed, outstretched. Caudal glands absent.

Hab. Sandy soil.

Genotype: T. typicus de Man, 1880.

* Although the name Brachynema is preoccupied, this genus seems of such doubtful validity that we refrain from renaming it. 
de Man, 1880, Tijdschr. Ned. dierk. Vereen., Loiden, $\mathbf{v}, 63$; 1884, Die frei . . . lebenden Nematoden d. Niederl. Fauna, 130; Micoletzky, 1922, Arch.f. Naturg., Abt. A, lxxxvii, 430.

12. Eephyadophora de Man, 1921.

Body extremely slender. Cuticle apparently unstriated, without bristles or alae. Head rounded, without distinct lips or papillac. Lateral organs apparently absent. Stylet with three knobs behind. Structure of oesophagus nnknown. Male with a large, pointed process on either side at about the level of the cloaca, curved posteriorly and a little inwards. The two processes are mited ventrally for about half their length. Two slender, equal spicules present. No accessory piece. Female unknown. (Description based on a single male specimen).

Hab. Soil.

Genotype : E. tenuissima de Man, 1921.

de Man, 1921, Capit. Zool., i, 35.

\section{Appendix to Anguillulinidae.}

We place here two forms which, owing to their possession of a buccal stylet, seem to have some relation to this family, but which are probably considerably modified as the result of their peculiar parasitic labits.

\section{a. Myenchus Schuberg \& Schröder, 1904.}

Head truncate. Lips indistinct. At about the anterior fifth of the body there is a ventral sucker-like organ. Buccal cavity narrow, containing a "stylet," which is not knobbed behind. Oesophagus short, consisting of two spindle-shaped swellings. Tail tapering in both sexes, with three terminal processes. Male with two short and broad spicules, with expanded roots. Apparently no accessory piece. Testis single, anterior, outstretched. Vulva at about the posterior fourth of the body. Female genital tubes paired, opposed; the posterior uterine branch vestigial and without ovary, the anterior ovary outstretched. Eggs few and large.

$\mathrm{Hab}$. In the connective tissue and (larvae) in the muselecells of a Leech (Nephelis).

Genotype: M. bothryophorus Schuberg \& Schröder, 1904.

Schuberg \& Schröder, 1904, Verh. Naturhist.-med. Ver., Heidelberg, N.F. vii, 629; 1904, Zeitschr. f. wiss. Zool., Ixxxvi, 509.

b. Myoryctes Eberth, 1863 .

Very small worms. Cuticle smooth. Head very slightly expanded. Mouth contains a stylet ending anteriorly in a 
minute knob. Oesophagus cylindroid, slightly expanded behind. Tail terminates, in both sexes, in an expanded knob. Male with two small spicules. Testis single, anterior, outstretched. Vulva at about the posterior fourth of the body. Female genital tubes short, paired, opposed, outstretched.

Hab. In galleries excavated under the sarcolemma of the muscle-fibres of Frogs.

Genotype: M. weismanni Eberth, 1863.

Eberth, 1863, Zeitschr.f. wiss. Zool., xii, 530.

Fam. 10. TRILOBIDAE Micoletzky, 1922.

Free-living forms, mostly marine, with a distinct buccal cavity without teeth. Oesophagus typically without a true muscular posterior bulb containing valves, but slightly expanded behind. Reproductive organs simple. Sexes generally distinct. Mostly oviparous, producing few and large eggs.

Micoletzky (1922) divides this family into three subfamilies, Trilobinae, Monhysterinae and Prismatolaiminae. The distinctions (based upon the form of the buccal capsule) between these subfamilies are relative rather than absolute, and appear to us too vague to justify the subdivision.

\section{Trilobus Bastian, 186.5.}

Cuticle unstriated, often with bristles. No lateral alae. Head not distinct, with a crown of stiff bristles, often in pairs. Lateral organs mostly unknown. Buccal capsule cup- or funnel-shaped, usually without teeth or local thickenings, its dorsal wall not jointed. Oesophagus with tooth-like processes near the anterior end but not immediately connected with the buccal capsule, and swollen posteriorly, but without bulb. Caudal end of male with preanal papillae and withont postanal papillae. Two spicules and an accessory piece present. 'Testes paired. Female genital tubes paired, opposed, reflexed. Eggs relatively numerous. Candal glands present. Spimneret present or absent.

Hab. Marine, fresh-water, or in sand or soil.

Genotype: T. gracilis Bastian, 1865.

Bastian, 1865, Trans. Linn. Soc. London, xxv, 93, 99; Micoletzky, 1922, Arch.f. Naturg., Abt. A, lxxxrii, 186.

Micoletzky (1922) divides the genus Trilobus into the subgenera Trilobus and Paratrilobus. The characters mentioned in the diagnoses of these subgenera appear to justify their separation as distinct genera. 


\section{Paratrilobus Micoletzky, 1922.}

Head with short bristles. Buccal capsule well-chitinized, somewhat barrel-shaped, with longitudinal ribs in its wall. Its wall appears jointed dorsally as seen in lateral view. Oesophagus with three teeth at its anterior end in immediate connection with the buccal capsule. Caudal end of male with six large preanal papillae. Remaining characters as in Trilobus.

Hab. Marine.

Genotype: P. grandipapilloides Micoletzky, 1922.

Micoletzky, 1922, Arch.f. Naturg., Abt. A, lxxxvii, 187, 188.

\section{Choanolaimus de Man, 1880.}

Cuticle striated, with granular sculpture, without bristles or lateral alae. Head not distinct, with two circumoral crowns of papillae but without bristles. Lateral organs large, spiral. Buccal capsule large, consisting of an anterior funnel-shaped portion, with walls composed of longitudinal rods, and a narrow posterior portion. Oesophagus cylindrical, slightly swollen behind. Caudal end of male without papillae. Two rodshaped accessory pieces present. Female genital tubes paired, opposed, reflexed. Caudal glands and spinneret absent.

Hab. Soil.

Genotype : C. psammophitus de Man, 1880.

de Man, 1880, Tijdschr. Nederl. dierk. Vereen., Leiden, 28; 1884, Die frei . . lebenden Nematoden d. Niederl. Fauna, 72 ; Micoletzky, 1922, Arch.f. Naturg., Abt. A, lxxxvii, 193.

\section{Anoplostoma Bütschli, 1874.}

Cuticle unstriated, usually with bristles. Head rather distinct, with a crown of bristles. Lateral organs variable. Buccal capsule very large, cup-shaped. Oesophagus swollen posteriorly. Caudal end of male typically with slight alae and papillae. An accessory piece present. Female genital tubes paired. Caudal glands present.

Hab. Marine.

Genotype: A. [Symplocostoma] viviparum (Bastian, 1865).

Bastian, 1865, Trans. Linn. Soc. London, xxv, 133; Bütschli, 1874, Abh. Senckenb. Ges., Frankfurt a. M., 272; de Man, 1885, Mém. Soc. Zool. France, i, 17.

\section{Sphaerolaimus Bastian, 1865.}

Cuticle smooth or transversely striated, with many bristles. Head distinct, with bristles. Lateral organs circular. Buccal capsule large, sub-spherical, with linear parietal thickenings. Oesophagus gradually swollen behind. Caudal end of male 
withont papillac. Aceessory pieee single, flattened and shield-shaped. Female genital tube single, anterior. Candal glands present.

Hab. Marine.

Genotype: S. hirsutus Bastian, 1865.

Bastian, 1865, Trans. Linn. Soc. London, xxv, 157; de Man, 1884, Die frei . . lebenden Nematoden d. Niederl. Fauna, 71.

\section{Didelta Cobb, 1920.}

Cuticle unstriated, without bristles, but with transversely elongated, refractive, bubble-like markings. Hcad with four long and six short bristles. Lateral organs large, longitudinally elliptical, "really spiral." Buccal capsule somewhat asymmetrical, goblet-shaped, its wall shorter dorsally than ventrally. Oesophagus somewhat narrower posteriorly. Male unknown. Female genital tubes paired, opposed, outstretched. Spinneret absent.

Hab. Marine.

Genotype: D. maculatum Cobb, 1920.

Cobb, 1920, Contr. Sci. Nematol., ix, 252 and key.

7. Desmolaimus de Man, 1880.

Cuticle smooth or striated, without bristles or lateral alae. Head not distinct, withont lips, with or withont bristles. Lateral organs, when present, circular. Buccal capsule cupshaped, with thin walls having three parallel annular thickenings or ridges, of which the innermost encircles the base of the capsule. Oesophagus expanded behind its middlie into a large bulb with widened lumen, and again somewhat enlarged posteriorly, but not forming a distinet muscular bulb. Candal end of male without papillae, but with several bristles. Spicules small, curved. The large aceessory piece has two posterior processes. Female genital tubes paired, opposed, outstretched.

Hab. Soil or water (fresh or brackish).

Genotype: D. zeelandicus de Man, 1880.

de Man, 1880, Tijdschr. Nederl. dierk. Vereen., Leiden, 14; 1884, Die frei . . . lebenden Nematoden d. Niederl. Fauna, 50; Micoletzky, 1922, Arch.f. Naturg., Abt. A, lxxxvii, 84.

\section{Myolaimus Cobb, 1920 .}

Cuticle finely striated, withont bristles or lateral alae. Head with confluent lips and two crowns of bristles. Lateral organs faint transverse slits. Bnccal capsule cup-shaped, with oesophageal teeth projecting at its base. Between the buccal capsule and the oesophagus is a pharynx surrounded by 
radial muscles. Oesophagus cylindrical, expanding behind into an elongate bulb. Caudal end of male with four adanal pairs of elongate papillae supporting membranous alae. Three other pairs of caudal papillae present, two of which are close to the tip. Spicules and aecessory piece possibly absent. Testis single, anterior, reflexed (?). Female genital tube single, anterior, reflexed. Caudal glands and spinneret absent.

Hab. Soil.

Genotype : $M$. heterurus Cobb, 1920.

Cobb, 1920, Contr. Sci. Nematol., ix, 274 and key; Micoletzky, 1922, Arch.f. Naturg., Abt. A, lxxxvii, 192.

\section{Zanema Cobb, 1920.}

Cuticle finely striated, without bristles or lateral alae. Head not distinet, with six (?) lips bearing appendages. A double crown of cephalie bristles present. Lateral organs circular. Pharynx "somewhat spheroidal." Oesophagus without posterior bulb. Caudal end armed with short, backwardly-projecting, thorn-like bristles, ten on each subventral line. Female genital tube probably single, anterior. Caudal glands and spinneret absent. Male unknown.

This diagnosis is based on a single, probably immature, female.

Hab. Marine.

Genotype : Z. acanthurum Cobb, 1920.

Cobb, 1920, Contr. Sci. Nematol., ix, 283 and key.

10. Paraphanolaimus Micoletzky, 1923.

Cuticle coarsely striated, without bristles. Narrow lateral alae present. Head not distinct, with four short bristles. Lateral organs open spirals. A short and broad buccal capsule present, prismatic or cylindrical. Oesophagus gradually thickened behind, with a slight posterior pear-shaped, feebly muscular bulb. Male unknown. Female genital tubes paired, opposed, reflexed, ovaries short. Viviparous or ovoviviparous. Caudal glands and spinneret present.

Hab. Fresh water.

Genotype : P. behningi Micoletzky, 1923.

Micoletzky, 1923, Arb. Biol. Wolga-Stat., vii, 23.

\section{Pseudonchus Cobb, 1920.}

Cuticle finely striated transversely, without bristles or lateral alae. Head not distinct, apparently with two lateral lips. Ten cephalic bristles present. Lateral organs spiral. Pharynx of irregular shape, with ridges, giving the appearance 
of teeth, in its wall. Oesophagus cylindrical, with indistinet pyriform bulb. Caudal end of male without supplementary organs, bristles or papillae. An accessory piece, without posterior process, present. Testis single, anterior, outstretehed. Female genital tubes paired, opposed, reflexed. Caudal glands and spimneret present.

Hab. Marine.

Genotype: P. rotundicephalus Cobb, 1920.

Cobb, 1920, Contr. Sci. Nematol., ix, 273 and key.

12. Monhystera Bastian, 1865.

Syn.* Monohystera de Man, et auett.; Tachyhodites Bastian, 1865̃; Theristus Bastian, 1865; Penzancia de Man, 1889; Austronema Cobb, 1914; Paramonohystera Steiner, 1916; Steineria Micoletzky, 1922, nec Filipjev, 1922; Allomonhystera Micoletzky, 1923.

Cuticle smooth or striated, usually with bristles, irregularly distributed or in submedian rows. Lateral alae absent. Head generally with indistinet lips, almost always with bristles. Lateral organs usually circular. Buecal eapsule very small, thin-walled, saucer-or eup-shaped, its walls continuous with the oesophageal lining, whieh is funnel-shaped anteriorly. Oesophagus eylindrieal, usually slightly expanded posteriorly, without distinct bulb. Ocelli sometimes present in aquatic forms. Two equal spicules and usually an aceessory piece present, the latter commonly with a posterior proeess. Test is generally single. Female genital tube usually single, anterior, outstretehed. Mostly oviparous. Caudal glands and spinneret usually present. Parthenogenesis common in nonmarine forms.

Hab. Aquatie (marine and fresh-water); also terricolous.

Genotype: M. stagnalis Bastian, 1865 (fide Stiles \& Hassall, $1905)$.

Bastian, 1865, Trans. Linn. Soc. London, xxv, 93, 97; de Man, 1884, Die frei . . lebenden Nematoden d. Niederl. Fauna, 35 ; Nieoletzky, 1922, Arch.f. Naturg., Abt. A, lxxxvii, 165.

\section{Daptonema Cobb, 1920.}

Cutiele thick, rather coarsely striated. Scattered bristles present in eervical region. Head rounded, not distinct, with

* We have included as synonyms a number of names which have been variously regarded by different authors as gencra or as subgenera of Monhystera. The available diagnoses of these forms are not mutually exclusive, and do not appear to us sufficient to separate them from Monhystera or from each other. Allomonhystera differs from the other forms in having three preanal papillae in the male, but is other. wise indistinguishable. 
twelve bristles. Six eversible lips present, each strengthened intcrnally by three dark, incurved, cuticular ribs. Oesophagus cylindroid, narrowing a little bebind. Spicules stout, brownish, curved laterally at the tips. Two accessory pieces present, curved like the spicules distally. Testes paired, opposed, ontstretched, Female genital tube single, anterior, ontstretched. Caudal glands apparently preanal. Spinneret present, armed with two bristles.

Hab. Marine.

Genotype : D. fissidens Cobb, 1920.

Cobb, 1920, Contr. Sci. Nematol., ix, 281 and key.

14. Dintheria de Man, 1921.

Cuticle finely striated, without bristles or lateral alae. Head with six bristles. Lateral organs large, transversely elliptical, with posterior border probably interrupted. Buccal capsule and oesophagus as in Monhystera. Caudal end of male with a series of median preanal papillae. Accessory piece absent. Spicules broad and short. Caudal glands and spinneret probably absent. Female unknown.

Hab. Soil.

Genotype : D. tenuissima de Man, 1921.

de Man, 1921, Capit. Zool., i, 9.

15. Monohystrella Cobb, 1918.

Buccal capsule more elongate than in Monhystera. Oesophagus with a rather distinct pyriform bulb posteriorly. Remaining characters, according to Cobb, are as in Monhystera. Nale unknown.

Hab. Fresh water.

Genotype: M. plectoides Cobb, 1918.

Cobb, 1918, Contr. Sci. Nematol., vii, 203.

Micoletzky (1922) has suggested that Monohystrella should be regarded as a subgenus of Terschellingia. The condition of the female genital tube and the presence of an oesophageal bulb induce us to retain it as a genus nearer to Monhystera than to Terschellingia.

\section{Cephalobellus Cobb, 1920.}

Cuticle rather coarsely striated. Head not distinct, subtruncate, withont bristles. Lateral organs absent or obscure. Six lips probably present. Pharynx conoid or pyramidal, small. Oesophagus cylindroid, with pyriform posterior bulb. Caudal end of male conical, without alae, but with a pair of elongate subventral preanal papillae and two median postanal papillae. A single slender spicule of irregular shape. Testis SYN. NEM. 
single, anterior, reflexed. Female unknown. Deseription based on a single male speeimen.

Hab. Intestine of the larva of a Lamellieorn beetle, living under cowdung, Australia.

Genotype : C. papilliger Cobb, 1920.

Cobb, 1920, Contr. Sci. Nematol., ix, 245 and key.

17. Trefusia de Man, 1893.

Cuticle unstriated, without bristles, except towards anterior end. Head trilobed, with bristles. Lateral organs elliptical. Oesophagus cylindrieal. Two spicules and an accessory piece present. Testes paired. Female genital tubes paired, opposed, reflexed.

Hab. Marine.

Genotype : T. longicauda de Man, 1893.

de Man, 1893, Mém. Soc. Zool. France, vi, 84; Micoletzky, 1922, Arch.f. Naturg., Abt. A, lxxxvii, 165.

18. Tripyloides de Man, 1886.

Cutiele unstriated, usually with bristles. Lateral alae apparently absent. Head with three large rounded lips, followed by strong bristles. Lateral organs spiral. Bueeal capsule small, distinet from oesophagus, funnel-shaped in front, and with two lateral pocket-like expansions behind. Oesophagus slightly swollen behind. Male with a median row of preanal papillae, extending to the anterior end of the body. Two equal spieules and an aeeessory piece, having a median plate and two lateral pieces. Testis single. Female apparently unknown. Caudal glands present.

Hab. Marine.

Genotype: T. vulgaris de Man, 1886.

de Man, 1886, Anatomische Untersuchungen über freilebende Nordsee-Nematoden, 60.

19. Bathylaimus Cobb, 1894, nec Daday, 1905, nec Ditlevsen, 1919.

Cuticle unstriated, but with bristles. Lateral alae apparently absent. Head with twelve bristles and three lips, the latter with bidentate borders, each armed with two projeeting bristles. Lateral organs spiral. Buecal capsule composed of two portions, a long anterior and a shorter posterior, of uniform diameter. Oesophagus elub-shaped. Caudal end of male without alae or papillae. Two large accessory picces present. Caudal glands present.

Hab. Marine.

Genotype : B. australis Cobb, 1894. 
Cobb, 1894, Proc. Linn. Soc. N.S.W., Sydney, viii, 409.

20. Axonolaimus de Man, 1889.

Syn. Conolaimus Filipjev, 1918.

Cuticle unstriated, but with bristles. Head with a crown of four bristles. Lateral organs large, elliptical imperfectly divided by a longitudinal crest. Buccal capsule fusiform, in two parts, the anterior enlarging posteriorly, the posterior diminishing. Oesophagus swollen posteriorly. Caudal end of male without alae or preanal papillae, but with several bristles on the ventral surface of the tail. An accessory piece, with two stout posterior processes, present. Female genital tubes paired, outstretched. Caudal glands present.

Hab. Marine (in sand).

Genotype : A. [Anoplostoma] spinosus (Bütschli, 1874).

Bütschli, 1874, Abh. Senckenb. Ges., Frankfurt a. M., 273; de Man, 1889, Mém. Soc. Zool. France, ii, 3.

Conolaimus angustilaimus, according to Filipjev (1918, Trav. Lab. Zool., Stat. Biol. Sebastopol, Ser. II, No. 4, 323), differs from Axonolaimus in the shape and position of its lateral organs, which are more circular in outline and situated very far forward. From Filipjev's figures it appears probable that these differences are largely due to different states of contraction in the mouth region.

\section{Scaptrella Cobb, 1917.}

The only diagnosis of this genus is contained in the legend to a figure and a "formula." It is said to have the general appearance of Axonolaimus, but to differ from it in having " jointed mandibles," circular lateral organs, a single ovary, and only "faint" accessory pieces. Cuticle coarsely striated. Head with twelve bristles. Testes paired, opposed, ontstretched (?). Female genital tube single, anterior, outstretched. Spinneret present.

Hab. Not given.

Genotype : S. cincta Cobb, 1917.

Cobb, 1917, Contr. Sci. Nematol., v, 119.

\section{Polylaimium Cobb; 1920.}

Cuticle very finely striated, apparently without bristles or lateral alae. Head with three or six lips, and without bristles. Lateral organs large, circular. Buccal capsule tubular, elongate, with a narrower anterior and a wider posterior portion. Oesophagus with a very small, elongate or pyriform posterior bulb. Caudal bristles absent. Genital tubes paired, opposed, reflexed. Caudal glands and spinneret present. Apparently hermaphrodite. 
Hab. Marine.

Genotype: P. exile Cobb, 1920.

Cobb, 1920, Contr. Sci. Nematol., ix, 274 and key.

23. Ascolaimus Ditlevsen, 1919.

Syn. Bathylaimus Ditlevsen, 1919, nec Cobb, 1894, nec Darlay, 1905.

Cuticle very finely striated, apparently without bristles or lateral alae. Head rather distinet, with papillae and a crown of bristles. Lateral organs large, donble, ineipient spirals. Buceal capsule a long and narrow fummel whose walls are eontinuous with the lining of the oesophagus. Oesophagus slightly swollen behind. Male unknown. Female genital tubes paired, opposed, outstretehed.

Hab. Marine.

Genotype: A. filiformis Ditlevsen, 1919.

Ditlevsen, 1919, Vid. Medd. Naturh. Foren., Copenhagen, $1 \times x, 168,299$.

24. Stephanolaimus Ditlevsen, 1919.

Cutiele eoarsely striated, apparently without bristles or lateral alae. Head with a fumel-shaped eireumoral dilatation, and with four long bristles. Lateral organs absent (?). Buecal eapsule moderately large, fumnel-shaped, continuous with lining of oesophagus. Oesophagus swollen posteriorly. Male unknown. Vulva behind the middle of the body.*

Hab. Marine.

Genotype: S. elegans Ditlevsen, 1919.

Ditlevsen, 1919, Vid. Medd. Naturh. Foren., Copenhagen, lxx, 183 .

25. Dactylaimus Cobb, 1920.

Cutiele rather coarsely striated, without bristles. Head with six lips (of whieh three are larger than the others) with hooked bristles at their tips. Twelve cephalie bristles present. Lateral organs spiral.† Bneeal eapsule fumel-shaped. Oesophagus gradually swollen behind. Male unknown. Female genital tube single, anterior, outstretehed. Deseription based on a single immatmre female speeimen.

Hab. Marine (in mud).

Genotype: $D$. aequalis Cobb, 1920.

Cobb, 1920, Contr. Sci. Nematol., ix, 250 and key.

* Description based on a single immature femalo.

$\uparrow$ According to the key circular or elliptical, but in the figure distinetly spiral. 


\section{Krampia Ditlevsen, 1921.}

Cuticle apparently unstriated, with a few rather fine bristles anteriorly. Head somewhat distinct, truncate, with four (?) rounded, somewhat swollen lips, and with a crown of stout bristles. Lateral organs unknown. Buccal capsule funnelshaped. Oesophagus gradually swollen behind, and with chitinoid thickenings externally at the level of the buceal capsule. Male without accessory piece, supplementary organs or caudal papillae. Female genital tube single, anterior.

Hab. Marine.

Genotype : K. acropora Ditlevsen, 1921.

Ditlevsen, 1921, Vid. Medd. Naturh. Foren., Copenhagen, lxxiv, 57.

27. Leptogastrella Cobb, 1920.

Cuticle finely striated, with bristles in cervical and caudal regions. Lateral alae absent. Head with thrce or six lips and a crown of eighteen to twenty bristles. Lateral organs inconspicuous. Buccal cavity wide and funnel-shaped. Oesophagus without posterior bulb. Caudal end of malc without supplementary organs or papillae. The spicules slide in tubular accessory pieces. Testis and female genital tube single, anterior, outstretched. Caudal glands and spiuneret present.

Hab. Marine (in mud).

Genotype : L. pellucida Cobb, 1920.

Cobb, 1920, Contr. Sci. Nematol., ix, 249 and key.

28. Margonema Cobb, 1920.

Cuticle unstriated, without bristles or lateral alae. Head not distinct, with three double lips but without bristles. Lateral organs spiral. Buccal cavity large, continuous with lining of oesophagis. Oesophagus without bulb. Male with thirty to forty supplementary organs close together, and a few scattered subventral caudal bristles. Accessory pices with posterior processes. Testis single, anterior, outstretched. Female genital tubes paired, opposed, outstretched. Caudal glands and spinneret present.

Hab. Marine.

Genotype: M. ringens Cobb, 1920.

Cobb, 1920, Contr. Sci. Nematol., ix, 248 and key.

29. Xenolaimus Cobb, 1920.

Cuticle coarsely striated, without bristles but with twelve longitudinal alae. Head protrusible, with a cuticular collar. Six thick, somewhat digitate lips and a crown of cephalic 
bristles present. Each lip with a two-jointed bristle and apparently also armed internally with a slender, flexible element longer than the bristle. Lateral organs circular or elliptical. Buceal cavity large and funnel-shaped. Oesophagus probably without bulb. Caudal glands and spinneret present. Genital organs not described.

The diagnosis is apparently based upon immature specimens.

Hab. Marine (in mud).

Genotype: X. striatus Cobb, 1920.

Cobb, 1920, Contr. Sci. Nematol., ix, 250 and key.

30. Necticonema Marion, 1870.

Cuticle finely striated, and with fine granulations. Head blunt, with small papillae and a crown of bristles. Buccal capsule very narrow, consisting of a slight dilatation of the oesophageal lumen. "[" No chitinous armature in mouth."] Male with broad spicules and several anterior accessory pieces of varying shape.

Hab. Marine.

Genotype: N. prin $\approx i$ Marion, 1870.

Marion, 1870, Ann. Sci. Nat., Paris (Zool.), xiii, 32, $: 34$.

\section{Coinonema Cobb, 1920.}

Cuticle finely striated, without lateral alae, apparently with bristles towards anterior end (figure). Head not distinet, with four bristles. Lateral organs spiral, somewhat hookshaped. Buccal capsule "obscure" (tubular in figure). Oesophagus slightly enlarged posteriorly. Two ocelli present. Spicules slender. Two accessory pieces present, with blunt posterior processes. Testes and female genital tubes paired, opposed, outstretched. Caudal glands and spimeret present.

Hab. Marine.

Genotype : C. punctatum Cobb, 1920.

Cobb, 1920, Contr. Sci. Nematol., ix, 259 and key.

\section{Prismatolaimus de Man, 1880.}

Cuticle finely striated, usually without bristles or lateral alae. Head not distinct, without lips but with bristles. Lateral organs linear, indistinct. Buccal capsule short, prismatic, unarmed. Oesophagiss scarcely enlarged posteriorly. Male with a median row of preanal papillae, extending forward into the oesophageal region. Accessory piece absent. Female genital tubes paired and opposed, or unpaired, anterior and reflexed. Caudal glands present.

Hab. Soil or fresh water.

Genotype : P. [Monhystera] intermedius (Bütschli, 1873). 
Bütschli, 1873, Nova Acta k. Leop.-Car. Akad. Naturf., Dresden, xxxvi, 67; de Man, 1880, Tijdschr. Nederl. dierk. Vereen., Leiden, 31-33; 1884, Die frei . . lebenden Nematoden d. Niederl. Fauna, 79; Micoletzky, 1922, Arch.f. Naturg., Abt. A, Ixxxvii, 195.

\section{Anonchus Cobb, 1913.}

Cuticle finely striated, without bristles or lateral alae. Head with four bristles. Lateral organs spiral. Buccal capsule tubular, unarmed. Oesophagus without posterior bulb. Caudal end of male with twenty tubular supplementary organs. Four to five caudal bristles present. An accessory piece present. Testis and female genital tube single, anterior, reflexed.

Hab. Fresh water.

Genotype : A. monohystera Cobb, 1913.

Cobb, 1913, Journ. Washington Acad. Sci., iii, 444 and key.

34. Araeolaimus de Man, 1888.

Syn. Spira de Man, 1877, nec Bastian, 1865.

Cuticle unstriatcd, but usually with small submedian bristles. Head without lips, but with a crown of four bristles. Lateral organs spiral. Buccal capsule a rather short, slender tube, narrowing gradually behind. Oesophagus gradually cxpanded behind. Ocelli sometimes present. Caudal end of male without papillae. Two strongly-curved spicules, and an accessory piece with two posterior processes, present. Female genital tubes paired, opposed. Caudal glands and spinneret present.

Hab. Marine.

Genotype : A. [Spira] bioculatus (de Man, 1877).

de Man, 1877, Tijdschr. Nederl. dierk. Vereen, 's Gravenhage and Rotterdam, 107; 1888, Mém. Soc. Zool. France, i, 14; Filipjev, 1922, Act. Inst. Agronom. Stauropol., i (Zool.), (16), 176.

\section{4a. Subgenus Araeolaimoides de Man, 1893.}

Subgen. of Araeolaimus. The type of this subgenus differs from that of Araeolaimus in the apparent absence of a buccal capsule and in the oval enlargement of the oesophagus behind the ocelli.

Genotype : A. microphthalmus de Man, 1893.

de Man, 1893, Mém. Soc. Zool. France, vi, 86; Filipjev, 1922, Act. Inst. Agronom. Stauropol., i (Zool.), (16), 175. 


\section{Fimbrilla Cobb, in Stiles \& Hassall, 1905.}

Syn. Fimbria Cobb, 1894, nec Megerle, IS1I.

Cuticle striated, with bristles at least at posterior end. Hearl somewhat distinct, with a crown of bristles. Buccal capsule prismoid. Oesophagus expands gradually behind. Caudal end of male withont alae or supplementary organs. Two accessory pieces, nearly as long as the spicules, joined posteriorly and protrusible. Female unknown.

Hab. Marine (among seaweed).

Genotype : F. [Fimbria] tenuis (Cobb, 1894).

Cobb, 1894, Proc. Linn. Soc. N.S.W., Sydney, viii, 421 ; Stiles \& Hassall, 1905, U.S. Dept. Agric., Bur. Anim. Indust. Bull. 79, 107.

\section{Anticyathus Cohb, 1920.}

Cuticle very finely striated, with scattered papilloid cervical bristles. Head not distinct, with two erowns of short bristles. Lateral organs circular. Buecal capsule very small, prismoid. Oesophagus club-shaped. Caudal end of male with twentyfive papilloid preanal supplementary orgaiss and a single papilla-like ventral bristle. An accessory piece, with a posterior process, present. Testes and female genital tubes paired, opposed, outstretched. Caudal glands and spinneret absent.

Hab. Marine (in sand).

Genotype: A. tenuicaudatus Cobb, 1920.

Cobb, 1920, Contr. Sci. Nematol., ix, 245 and key.

37. Sphaerocephalum Filipjev, 1918.

Cuticle finely striated. Head with six small papillae, ten long and fine bristles and some supplementary bristles. Lateral organs spiral (apparently circular in figure). Buccal capsule, aceording to figure, extremely short and narrow, with wall gradually thickened posteriorly, giving it the appearance of a cone. Oesophagus slightly swollen at eaeh end, but without bulb. Tail of female very thick, with subterminal spinneret. Female genital tubes paired, opposed, outstretched; the posterior without ovary. Male unknown.

Hab. Marine.

Genotype : S. crassicauda Filipjev, 1918.

Filipjer, 1918, Trav. Lab. Zool., Stat. Biol. Sebastopol, Ser. II, No. 4, 317, 328.

\section{Appendix to Trilobidae.}

The following genera are doubtfully referred to this family. The position of several of them is very uncertain, and can only 
be established when much more complete descriptions are available.

\section{a. Acmaeolaimus Filipjev, 1918.}

Cuticle thick, finely striated. Head with two cromns each of six papillae, and four stont bristles. Lateral organs like thick plates, with spirals within. Buccal capsulc like a shallow cup, its dorsal wall thickened and prolonged posteriorly. Internal anatomy unknown.

Hab. Marine.

Genotype: A. diplopeltoides Filipjev, 1918.

Filipjev, 1918, Trav. Lab. Zool., Stat. Biol. Sebastopol, Ser. II, No. $4,345$.

\section{b. Symplocostoma Bastian, 1865.}

Cuticle without striations or bristles. Head not distinct, with or without bristles. Latcral organs unknown. Pharynx clongate, "somewhat fiddle-shaped, having a peculiar funnclshaped body lying along its inferior aspect, and an appearance of three or more circular lines around the parietes." Ocsophagus widening considerably but gradually behind, without bulb. Ocelli present or absent. Caudal end of male apparently without supplementary organs or papillae. Accessory picce absent. Female genital tubes paired, opposed. Caudal glands and spinneret present.

Hab. Marine.

Genotype: S. longicolle Bastian, 1865.

Bastian, 1865, Trans. Linn. Soc. London, xxr, 132.

This genus was only tentatively proposed by Bastian, and its validity is somewhat uncertain.

\section{c. Pelagonema Cobb, 1894.}

Cuticle unstriated, without bristles. Head not distinct. Lateral organs inconspicuous. Pharynx simple, elongate, without teeth. Oesophagus gradually swollen in its posterior half. Male unknown. Female genital organs paired, opposed, reflexed. Caudal glands present.

Hab. Marine.

Genotype: P. simplex Cobb, 1894.

Cobb, 1894, Proc. Linn. Soc. N.S.W., Sydney, viii, 391.

This genus is considered by Cobb, in spite of the absence of teeth, to be related to Oncholaimus.

\section{d. Diplohystera Onorato-de Cillis, 1917.}

Body considerably swollen in middle region. Cuticle smooth, without bristles or lateral alae. Head not distinct, 
truncate, produced into a kind of low collar, and without lips, papillae or bristles. Lateral organs circular. Buccal cavity snall, funnel-shaped, unarmed. Oesophagus cylindrical, slightly swollen bchind. Male unknown. Female genital tubes paired, opposed, reflexed. Caudal glands well developed.

Hab. Fresh water.

Genotype: D. inflata Onorato-de Cillis, 1917.

Onorato-de Cillis, 1917, Monit. Zool. Ital., xxviii, (4-5), 58.

\section{e. Seuratiella Ditlevsen, 1921.}

Syn. Seuratia Ditlevsen, 1919, nec Skrjabin, 1916.

Cuticle striated. Head truncate, with a single crown of short, rather stout bristles. Lateral organs spiral. Pharynx shallow and not very spacious, without teeth. Oesophagus cylindrical, without bulb. Caudal end of male with one large and three smaller preanal supplementary organs. Accessory pieces rod-shaped. Female unknown (description based on a single male specimen).

Hab. Marine.

Genotype: S. [Seuratia] gracilis (Ditlevsen, 1919).

Ditlevsen, 1919, Vid. Medd. Naturh. Foren., Copenhagen, lxx, 197; and 1921, lxxiv, 60.

According to Ditlevsen, this genus is closely related to Cyatholaimus, but differs in the shallowness of its buceal capsule and in the absence of teeth.

\section{f. Cricolaimus Sonthern, 1914.}

Cuticle finely striated. Hearl romnded, with a single crown of four long submedian bristles. Lateral organs in the form of thick spirals. Buccal cavity small and narrow, surrounded at its jumction with the oesophagus by a stout chitinoid ring. Oesophagus with a posterior bulb. Caudal end of male with a median ventral series of supplementary organs. Spicules simple, curved. An accessory piece present, in the form of a flattened plate with a stout posterior process.

Hab. Marine (in sand).

Genotype : $C$. elongatus Sonthern, 1914.

Sonthern, 1914, Proc. R. Irish Acad., xxxi, 20.

\section{g. Platycoma Cobb, 1894.}

Cuticle unstriated, but with bristles throughont, which are inconspicuous except at the anterior end. Head separated from body by a broad and shallow constriction. Three small conical lips (termed teeth by Southern) and ten cephalic bristles present. Lateral organs more or less circular. 
Pharynx " narrow, almost tubular, but expanding very slightly half-way back." Oesophagus cylindrical, without bulb. Caudal end of male with or without preanal or postanal papillae or both. An accessory piece present, with two posterior processes, each with a bifid end. Female genital tubes paired, opposed, outstretclied.

Hab. Marine (in sand).

Genotype : P. cephalata Cobb, 1894.

Cobb, 1894, Proc. Linn. Soc. N.S.W., Sydney, viii, 399; Southern, 1914, Proc. R. Irish Acad., xxxi, 33.

Cobb based the genus on the description of a single male specimen. Southern records what he believes to be the same species, and adds a description of the female.

\section{h. Solenolaimus Cobb, 1894.}

Cuticle unstriated, but with bristles distributed throughout the surface of the body. Head rounded, with minute lips and two crowns of short bristles. Lateral organs circular (?). Pharynx narrow, tubular. Oesophagus spindle-shaped anteriorly, slender; posteriorly swollen and muscular. Malo unknown. Tail of female subcylindrical, with rounded tip. Caudal glands absent.

Hab. Marine (in sand).

Genotype: S. obtusus Cobb, 1894.

Cobb, 1894, Proc. Linn. Soc. N.S.W., Sydney, viii, 419.

\section{i. Eleutherolaimus Filipjev, 1922 .}

Cuticle thin, finely striated, apparently without bristles. Head not distinct, with six papillac and four bristles. Lateral organs circular. According to the figure, there is a wide, cylindrical buccal capsule which is prolonged anteriorly into a crown of convergent chitinoid rodlets (giving the whole structure much the appearance of the mouth of an Oesophagostome). Oesophagus gradually swollen posteriorly, without bulb. An accessory piece present, with two posterior processes.

Hab. Marine.

Genotype: E. longus Filipjev, 1922.

Filipjev, 1922, Act. Inst. Agronom. Stauropol., i (16), 173.

The genus Eleutherolaimus is proposed by Filipjev for the reception of his species longus (described from a single male specimen), and of six other species which have been previously referred to Monhystera and Terschellingia. The unusual structure of the buccal capsule makes it imperative that the genotype should be better known before the genus can bo accepted and the older species included in it. 
j. Trilepta Cobb, 1920.

Cuticle unstriated, without bristles exeept anteriorly. Head slightly expanded, with two crowns of bristles, the posterior long and apparently jointed. Lateral organs short transverse slits. Pharynx wide, almost eylindrieal, perhaps containing a single tooth at its anterior end. Oesophagus cylindroid, without bulb. Candal end of male without supplementary organs. Spicules slender. An ineonspicuous aceessory piece present. Testis single, anterior, outstretched. Female undescribed. Caudal glands and spinneret apparently absent.

Hab Marine (in sand).

Genotype: T. guttata Cobb, 1920.

Cobb, 1920, Contr. Sci. Nematol., ix, 312 and key.

Fam. 11. ALAIMIDAE Micoletzky, 1922.

Free-living forms, mostly marine, but sometimes terricolous or fresh-water. Buccal cavity absent or extremely small. Oesophagus generally without a true muscular bulb eontaining valves. Reproductive organs simple. Sexes generally distinct. Oriparous, producing few and large eggs.

Micoletzky (1922) proposes to divide this family into two subfamilies, Alaiminae and Leptosomatinae. The distinction between these subfamilies is that in the latter a ventral excretory gland, or lateral canals and an excretory pore, are present, while they are said to be absent in the former. It is scarcely credible that there are any forms without some such structures, though they may occasionally be very hard to detect. We have therefore felt it unjustifiable to retain the proposed subfamilies.

\section{Alaimus de Man, 1880.}

Cuticle unstriated, without bristles or lateral alae. Head not distinct, without bristles. Lips absent. Oesophagus elongate, expanding gradually behind. Caudal end of male usually with a median row of three to five preanal papillac. No accessory piece present. Testis single. Female genital tube single, posterior. Sometimes parthenogenetic. No caudal glands or spinneret.

Hab. Soil and plant-roots.

Genotype: A. primitivus de Man, 1880.

de Man, 1880, Tijdschr. Nederl. dierk. Vereen., Leiden, 2; 1884, Die frei . . lebenden Nematoden der Niederl. Fauna, 29; Nicoletzky, 1922, Arch.f. Naturg., Abt. A, Ixxxvii, 134. 


\section{Alaimella Cobb, 1920.}

Cuticle coarsely striated, with bristles only at the ends. Lateral alae apparently absent. Head not distinct, with four bristles. Lateral organs circular, open behind. Lips confluent. Oesophagus somewhat club-shaped. Spicules slender. Two simple accessory pieces present. Testes paired, parallel. Female genital tubc probably single, posterior, reflexed. Caudal glands and spimneret present.

Hab. Marine.

Genotype : A. truncata Cobb, 1920.

Cobb, 1920, Contr. Sci. Nematol., ix, 234 and key.

\section{Anticoma Bastian, 1865 .}

Cuticle unstriated, with small scattered bristles throughout, and with special longitudinal rows of longer bristles, on the lateral and sometimes on the submedian lines, in the neck region. Head with ten bristles. Lateral organs slitlike. Lips three, rudimentary, rarely with papillae. Oesophagus club-shaped. Ocelli absent. Male without candal alae. A single sigmoid preanal supplementary organ present. Caudal papillae, if present, inconspicuous. A few small anal bristles present. Spicules equal. Testes paired, both running antcriorly, but one usually reflexed near its end. Female genital tubes paired, opposed, reflexed. Caudal glands and spinneret present.

Hab. Marine.

Genotype : A. eberthi Bastian, 1865.

Bastian, 1865, Trans. Linn. Soc. London, xxv, 141; Cobb, 1890, Proc. Linn. Soc. N.S.W., Sydney, v, 765.

\section{Enchelidium Ehrenberg, 1836.}

Cuticle unstriated, with small, scattered bristles. Head sometimes distinct, with a crown of bristles. Lateral organs transversely elliptical. Lips indistinct. No buccal cavity. Oesophagus gradually swollen behind, and surrounded near its anterior end by a single large mass of pigment bearing two, or rarely three, lenses. Caudal end of male nsually with a median series of preanal papillae. Spicules equal, slender, slightly curved.

Hab. Marine.

Genotype : E. [Vibrio] marinum (Müller, 1783).

Müller, 1783, 163 (fide Stiles \& Hassall, not verified); Ehrenberg, 1836, Die Akalephen des Rothen Meeres, etc., Abh. k. Akad. Wiss., Berlin, for 1835, 219, 235 (Sep. 1836, 41, 57); de Man, 188s, Mlém. Soc. Zool. France, i, 12. 


\section{Aegialolaimus de Man, 1907.}

Cuticle striated but without bristles. Head slightly wider than neck, without lips or bristles. Lateral organs large, eircular. Oesophagus with a posterior bulb and very wide lumen. Hale unknown. Female genital tubes probably double and reflexed. Caudal glands present.

Hab. Marine.

Genotype: A. elegans de Nan, 1907.

de Man, 1907, Tijdschr. Nederl. dierk. Vereen., Leiden, x, 228 .

\section{Aphanolaimus de Man, 1880 .}

Cuticle coarsely striated, withont bristles. Lateral alae present. Head not distinct, with stont bristles, but without lips. Lateral organs cireular or spiral, very large. Oesophagus cylindrical, not enlarged posteriorly. Caudal end of male with a median row of protrusible supplementary organs, also lateral preanal and postanal "bristle-papillae." An accessory piece present. Testes paired. Female genital tubes paired, symmetrical, rather short, apparently reflexed. Caudal glands and spimneret present. Sometimes hermaphrodite.

Hab. Marshy ground, fresh or brackish water.

Genotype: A. attentus de Man, 1880.

de Man, 1880, Tijdschr. Nederl. dierk. Vereen., Leiden, 5; 1884, Die frei... lebenden Nematoden der Niederl. Fauna, 34; Nicoletzky, 1922, Areh. f. Naturg., Abt. A, Ixxxvii, 142.

7. Halalaimus de Man, 1838.

Cuticle unstriated. Head without lips, but with a double crown of bristles. Lateral organs elongate, narrow, longitudinal grooves. Oesophagus slender, elongate, gradually enlarged behind. Male without caudal papillae. Two equal spicules and an accessory piece present. Testes paired. Caudal glands present.

Hab. Marine (littoral).

Genotype: $H$. gracilis de Man, 1888.

de Man, 18s8, Tijdschr. Nederl. dierk. Vereen., Leiden, 2; Filipjer, 1922, Act. Inst. Agronom. Stanropol., i (Zool.), 100.

\section{Iotalaimus Cobb, 1920.}

Cuticle coarsely striated, without bristles. Crenate lateral alae present. Head not distinct, without bristles. Lateral organs semi-elliptical. Oesophagus slightly swollen posteriorly. Caudal end of male with some small postanal papillae. An accessory piece present. Testis and female genital tube single, anterior, reflexed. No candal glands or spinneret. 
Hab. Soil.

Genotype : I. striatus Cobb, 1920.

Cobb, 1920, Contr. Sci. Nematol., ix, 239 and key.

9. Bastiania de Man, 1876.

Cuticle striated, without bristles. Lateral alae absent. Head not distinct, without lips, but with bristles. Lateral organs spiral. Oesophagus elongate and gradually, but slightly, swollen behind. Male with a ventral row of small papilliform supplementary organs extending throughout the greater part of the body. Spicules stout. No accessory piece. Testes paired. Female genital tubes paired, symmetrical. Caudal glands and spinneret present.

Hab. Soil.

Genotype : $B$. gracilis de Man, 1876.

de Man, 1876, Tijdschr. Nederl. dierk. Vereen.,'s Gravenhage and Rotterdam, 172; 1SS4, Die frei . . lebenden Nematoden der Niederl. Fauna, 33; Micoletzky, 1922, Arch. f. Naturg., Abt. A, lxxxvii, 140.

10. Deontolaimus de Man, 1880.

Cuticle finely striated, without bristles or with few bristles. Lateral alae sometimes present. Head not distinct, without lips, but sometimes with fine bristles. Lateral organs absent. Oesophagus swelling slightly and gradually behind. Male with a row of ventral preanal papillae and one ventral postanal papilla. Spicules large. A small rod-shaped accessory piece present. Testis single. Female genital tubes paired, symmetrical. Caudal glands and spinneret present.

Hab. Fresh or brackish water.

Genotype : D. papillatus de Man, 1880.

de Man, 1880, Tijdschr. Nederl. dierk. Vereen., Leiden, 3; 1884, Die frei . . lebenden Nematoden der Niederl. Fauna, 31 ; Micoletzky, 1922, Arch.f. Naturg., Abt. A, lxxxvii, 141.

\section{Thalassoalaimus de Man, 1893.}

Cuticle unstriated, without bristles. Lateral alae apparently absent. Head without lips, but with bristles. Lateral organs sinall, probably in the form of transverse grooves. Oesophagus slender, expanding posteriorly. Caudal end of male with preanal papillae. Spicules short. An accessory piece present. Female genital tube single, posterior, reflexed. Caudal glands present.

Hab. Marine.

Genotype : T. tardus de Man, 1893.

de Man, 1893, Mém. Soc. Zool. France, vi, 81. 


\section{Bolbinium Cobb, 1920.}

Cutiele finely striated, withont bristles or lateral alae. Head not distinet, without lips or bristles, but with six papillae. Lateral organs large, deeply plaeed. Oesophagus with a pyriform posterior swelling. Tail of male short and rounded. A vestigial spicule.* No aceessory piece or supplementary organs. Candal glands and spimneret absent. Female unknown.

Hab. Soil.

Genotype: B. brevicolle Cobb, 1920.

Cobb, 1920, Contr. Sci. Nematol., ix, 240 and key; Mieoletzky, 1922, Arch.f. Naturg., Abt. A, lxxxvii, 161.

\section{Cyartonema Cobb, 1920.}

Cuticle fincly striated, withont bristles except for a few on the tail. Slight lateral alae present. Head with four bristles and six minute papillae. Lateral organs large and eircular. Oesophagus narrow, expanding gradually behind. Candal end of male without supplementary organs. An aceessory pieee present, with a long posterior process. Testis single, anterior, outstretehed. Caudal glands and spinneret present.

Hab. Marine (in sand).

Genotype: C. flexile Cobb, 1920.

Cobb, 1920, Contr. Sci. Nematol., ix, 242 and liey.

\section{Tripyla Bastian, 1865.}

Syn. Tripula Bast., 1865; Trischistoma Cobb, 1913.

Cuticle striated or oeeasionally smooth, without bristles. Head not distinet, with three lips and with papillae and bristles, or bristle-like papillae. Lateral organs apparently absent. Oesophagus slightly swollen posteriorly. Caudal end of male usually with a long, ventral row of preanal papillae. No accessory piece. Testes paired. Female genital tubes generally paired, symmetrieal, reflexed. Caudal glands and occasionally a spimeret present.

Hab. Soil and fresh water, rarely marine.

Genotype: $T$. glomerans Bastian, 1865.

Bastian, 1865, Trans. Linn. Soc. London, xxv, 93, 115; de Man, 1884, Die frei . . . lebenden Nematoden der Niederl. Fauna, 44; Micoletzky, 1922, Arch.f. Naturg., Abt. A, lxxxvii, 148.

* Cobb states in lis description of tho genotype that "the spiculum is vestigial," but in the key to genera the genus is placed among forms with "spicules two, equal, more or less areuate." 


\section{Nuada Southern, 1914.}

Cuticle smooth, extremely thick, without bristles or lateral alae. Head distinct, with four bristles. Lateral organs apparently absent. Oesophagus very long and slender. An accessory piece present. Female genital tubes paired, opposed.

Hab. Marine.

Genotype : N. leptosoma Southern, 1914.

Southern, 1914, Proc. R. Irish Acad., xxxi, 9.

16. Leptosomatum Bastian, 1865.

Syn. Phanoglene Eberth, 1863, nec Nordmann, 1840; Enoplus Eberth, 1863, nec Dujardin, 1845.

Cuticle unstriated or with longitudinal markings, without bristles. Lateral alae apparently absent. Head with three lips and two crowns of papillae. Oesophagus gradually expanded posteriorly. A pair of ocelli present. Caudal end of male occasionally with supplementary organs or "suckers." An accessory piece present. Testes paired, opposed. Female genital tubes paired, opposcd, reflexed. Oviparous. Eggs comparatively numerous, smooth-shelled.

Hab. Marine.

Genotype : L. elongatum Bastian, 1865.

Bastian, 1865, Proc. Roy. Soc. London, xiv, 144; de Man, 1893, Mém. Soc. Zool., Paris, vi, 102.

\section{Acoma Steiner, 1916.}

Cuticle unstriated, without bristles. Head distinct, without lips but with bristles. Oesophagus expanded gradually behind. Male unknown. Tail of female elongate. Female genital tubes paired, symmetrical, reflexed. Caudal glands rudimentary. Spinneret absent.

Hab. Marine (Arctic).

Genotype: A. borealis Steiner, 1916.

Steiner, 1916, Zool. Jahrb., Syst., xxxix, 652.

18. Oxystomina nom. nov.*

Syn. Oxystoma Bütschli, 1874, nec Dum., 1806.

Cuticle unstriated, without bristles. Head with fine bristles in genotype. Lateral organs elliptical. Oesophagus slightly expanded behind. Caudal end of male with two preanal bristles. An accessory piece present. Testis single.

* The name Oxystomina has, we believe, been proposed to replace the preoccupied name Oxystoma. We are unfortunately unable to trace its author and date of publication.

SIN. NEM. 
Female genital tubes paired, the anterior branch vestigial. Caudal glands present.

Hab. Marine.

Genotype: O. [Oxystoma] elongatum (Bütschli, 1874).

Bütschli, 1874, Abh. Senckenb. Ges., Frankfurt a. M., ix, 270; Southern, 1914, Proc. R. Irish Acad., xxxi, 18.

\section{Litonema Cobb, 1920.}

Cuticle finely striated, withont bristles. Lateral alae present. Head without bristles. Lips not apparent. Lateral organs pore-like or perhaps absent. A very narrow, elongate buccal capsule possibly present. Oesophagus slightly expanded posteriorly. Genital organs undescribed.

Hab. Fresh water (swamp).

Genotype : L. nudum Cobb, 1920.

Cobb, 1920, Contr. Sci. Nematol., ix, 237 and key.

20. Hyalaimus Cobb, 1920 .

Cuticle with irregular markings and finely crenate eontour. Lateral fields broad, granular, with finely crenulate alae. Head truncate, withont bristles. Lips indistinct. A crown of six cephalie papillae present. Lateral organs absent. Oesophagus with an anterior ("pharyngeal ") swelling, and fusiform posteriorly. Nale undescribed. Tail of female conical, pointed. Female genital tubes paired, opposed, outstretched.

Hab. (Apparently a single specimen) in the intestine of an Earthworm (Australia).

Genotype: H. brevicollis Cobb, 1920.

Cobb, 1920, Contr. Sci. Nemaiol., ix, 238 and key.

21. Macroposthonia de Man, 1880.

Cuticle striated, apparently without bristles. Lateral alae present. Head without lips or bristles. Lateral organs not described. Oesophagus indistinctly separated from intestine. Tail of male completely surrounded by broad, bursa-like alae. Candal papillae absent. Spicules slender, extremely long. No accessory piece. Caudal glands absent. Female unknown.

Hab. Soil.

Genotype: M. annulata de Man, 1880.

de Man, 1880, Tijdschr. Nederl. dierk. Vereen., Leiden, 58; 1884, Die frei . . lebenden Nematoden der Niederl. Fauna, 124; Micoletzky, 1922, Arch.f. Naturg., Abt. A, lxxxvii, 163. 
22. Campylaimus Cobb, 1920.

Cuticle finely striated. Lateral alae present. Head with a terminal eap, set off by a minute constriction, and with bristles which are asymmetrically placed. Mouth ventral, without distinet lips. Lateral organs elongate, half hoopshaped. Oesophagus somewhat expanded behind. Testis apparcntly single. Female genital tubes paired, opposed, outstretched. Caudal glands "appcar to be located in front of the anus, probably a long distance in front of it."

Hab. Marine (in sand and mud).

Genotype: C. inaequalis Cobb, 1920.

Cobb, 1920, Contr. Sci. Nematol., ix, 232 and key.

23. Helalaimus Onorato-de Cillis, 1917.

Cuticle unstriated, without bristles. Head not distinct, without lips or bristles. Lateral organs eireular. No true buccal eapsule, but a very small cuticular vestibule. Oesophagus slightly expanded posteriorly. Tail of male apparently without preanal or postanal papillae. Spicules large. A small accessory piece present. Female genital tube single, anterior, outstretched. Caudal glands present.

Hab. Fresh water.

Genotype : H. psilocephalus Onorato-de Cillis, 1917.

Onorato-de Cillis, 1917, Monit. Zool. Ital., xxviii, 45, 58.

24. Hemicycliophora de Man, 1921.

Cuticle rather coarsely striated, without bristles. Head hemispherieal, distinet, without lips or bristles. Lateral organs probably elliptical. Oesophagus probably has a small bulb at about its middle. Caudal end of male alate, but without papillae. Spicules rather large. Presence of an accessory piece uncertain. Female unknown. Diagnosis based on a single male specimen.

Hab. Soil.

Genotype : H. typica de Man, 1921.

de Man, 1921, Capit. Zool., i, 33.

25. Ionema Cobb, 1920.

Cuticle thin, without bristles. Head without lips but with four bristles. Lateral organs small, labial, unelosed, very inconspicuous. Oesophagus eylindrical, diminishing in thickness posteriorly. Ocelli present. Male unknown. Caudal end without bristles. Female genital tubes paired, opposed, reflexed. Caudal glands and spinneret present. 
Hab. Marine (among Algae).

Genotype: I. ocellatum Cobb, 1920.

Cobb, 1920, Contr. Sci. Nematol., ix, 235 and key.

26. Leptonemella Cobb, 1920.

Cuticle striated, the striations retrorse posteriorly, the reverse anteriorly, without bristles or lateral alae. Head with eighteen small bristles. A few scattered bristles also present in the ecrvical region. Lips indistinet. Lateral organs apparently straight transverse slits. Oesophagus with wide pyriform posterior bulb. Caudal end of male with several submedian, slender, cuticular "thorns." An accessory piece present. Testes paired, opposed, outstretehed. Caudal glands and spinneret present. Female unknown.

Hab. Marine.

Genotype: L. cincta Cobb, 1920.

Cobb, 1920, Contr. Sci. Nematol., ix, 244 and key.

27. Litinium Cobb, 1920.

Cuticle smooth or faintly striated, without bristles or lateral alae. Head with twelve bristles. Mouth merely a pore. Oesophagus gradually expanded behind. Male unknown. Female genital tube single, posterior, reflexed.

Hab. Marine (in sand).

Genotype : $L$. aequale Cobb, 1920.

Cobl, 1920, Contr. Sci. Nematol., ix, 234 and key.

28. Litotes Cobb, 1920.

Cuticle thin, without bristles. Lateral organs very inconspicuous. Male apparently unknown. Female genital tube single, anterior, outstretched. Eggs few.

Hab. Marine (among Algae).

Genotype: L. minuta Cobb, 1920.

Cobb, 1920, Contr. Sci. Nematol., ix, 230 and key.

29. Molgolaimus Ditlevsen, 1922.

Cuticle apparently unstriated, withont bristles. Head rounded, not very distinet. Lateral organs absent. Oesophagus short and thin, with a large globular bulb posteriorly. [Another bulb may possibly be present.] Caudal end of male without postanal papillae but with two small preanal papillae. Spicules very long, filiform. No accessory piece scen. Female genital tubes paired, reflexed. Vulva somewhat in front of the middle of the body.

Hab. Marine.

Genotype: M. tenuispiculum Ditlevsen, 1922. 
Ditlevsen, 1922, Vid. Medd. Naturh. Foren., Copenhagen, Ixxiii, 2.

\section{Porocoma Cobb, 1920.}

Cutiele thin, finely striated, without bristles. Head with ten bristles, also a ventral bristle-like organ just behind the excretory pore. Mouth with relatively thick, minute lips. Lateral organs probably absent. Buocal capsule absent or vestigial. Oesophagus without bulb. Male unknown. Female genital tubes parallel, posterior. Caudal glands present.

Hab. Marine.

Genotype : P. striata Cobb, 1920.

Cobb, 1920, Contr. Sci. Nematol., ix, 236 and key.

\section{Nemella Cobb, 1920.}

Cuticle finely striated, without bristles. Head with four bristles. Lateral organs small, with obvious internal elements. Oesophagus cylindrical. Two ocelli present, with lenses. Caudal end of male without supplementary organs or bristles. An accessory piece present, with a posterior process. Female unknown.

Hab. Marine.

Genotype : N. ocellata Cobb, 1920.

Cobb, 1920, Contr. Sci. Nematol., ix, 236 and key.

\section{Schistodera Cobb, 1920.}

Cuticle thin, without bristles. Head withont bristles. Lateral organs large and deep, with strongly chitinized posterior wall. Oesophagus expanding suddenly posteriorly. Caudal end of male with a pair of inconspieuous preanal bristles and two or three minute submedian postanal bristles. A straight accessory piece present. Testes probably paired. Caudal glands and spinneret present. Female unknown.

Hab. Marine (among Algae and sand).

Genotype : S. exilis Cobb, 1920.

Cobb, 1920, Contr. Sci. Nematol., ix, 231 and key.

\section{Stilbonema Cobb, 1920.}

Cutiele with plain striations, retrorse posteriorly, the reverse anteriorly. Body with very short, slender, submedian bristles, six to nine striations apart. Head probably with a ring of very small papillae and twenty bristles. Lateral organs small, tubular, labial. Oesophagus very narrow, with pyriform posterior bulb. Caudal end of male with a row of aeorn-shaped supplementary organs extending far forward. Spicules slender [very broad in figure]. Two parallel 
aceessory pieces present. Testis single, anterior, ontstretched. Candal glands and armed spinneret present.

Hab. Marine.

Genotype: S. brevicolle Cobb, 1920.

Cobb, 1920, Contr. Sci. Nematol., ix, 242 and key.

34. Stenolaimus Marion, 1870.

Cuticle with bristles, eloser together towards anterior end. Head with six bristles, with or without papillae. Oesophagus club-shaped. Male with long slender spienles and two aceessory pieces. Female genital tubes paired, opposed, reflexed, the anterior branch being vestigial. Caudal glands and spinneret present.

Hab. Marine.

Genotype : S. lepturus Marion, 1870.

Marion, 1870, Ann. Sci. Nat., Paris, Zool., (5) xiii, (Art. 14), 16.

35. Tyenodora Cobb, 1920.

Cuticle thick, apparently unstriated and without bristles. Lateral alae absent. Head with ten bristles. Lateral organs linear. Oesophagus apparently without bulb. Male apparently unknown. Female genital tubes paired, opposed, reflexed. Caudal glands and spinneret present.

Hab. Marine.

Genotype : T. pachydermata Cobb, 1920.

Cobb, 1920, Contr. Sci. Nematol., ix, 231 and key.

36. Xennella Cobb, 1920.

Cutiele unstriated, with six to eight longitudinal ribs or alae on each side of the body, without bristles. Head mitriform, distinct, with four or six bristles. Lateral organs transversely elliptical, open behind. Oesophagus narrow, gradually expanded posteriorly. Male with two aecessory pieces. Caudal glands and possibly spinneret present. Female unknown. [Type speeimens immature.]

Hab. Marine.

Genotype : X. cephalata Cobb, 1920.

Cobb, 1920, Contr. Sci. Nematol., ix, 233 and key.

\section{Neurella Cobh, 1920.}

Cuticle finely striated, without bristles, but with narrow lateral alae. Head not distinct, with apparently three lips and four bristles. Lateral organs spiral. Buecal eavity small. Oesophagus without bulb. Caudal end of male apparently with a single flattened supplementary organ. 
Testes paired, parallel. Female genital tubes paired, opposed (?). Caudal glands and spinneret apparently absent.

Hab. Marine.

Genotype : N. simplex Cobb, 1920.

Cobb, 1920, Contr. Sci. Nematol., ix, 246 and key.

38. Nannolaimus Cobb, 1920.

Cuticle coarsely striated, without bristles except in cervical region. Head not distinct. Lips confluent. Two crowns of cephalic bristles present. Lateral organs spiral. Buccal cavity very small. Oesophagus without bulb. Ocelli present. Male unknown. Caudal end of female with a few median bristles. Female genital tubes paired, opposed, reflexed. Caudal glands and spinneret present.

Hab. Marine.

Genotype: N. guttatus Cobb, 1920.

Cobb, 1920, Contr. Sci. Nematol., ix, 255 and key.

39. Cytolaimium Cobb, 1920.

Cuticle finely striated, without bristles. Head not distinct, with six papillae and six stout three-pointed bristles. Lateral organs circular, open behind. Buccal capsule very small. Oesophagus cylindrical. Caudal end of male with sixteen pairs of discoid subventral supplementary organs, of which five are postanal. A slender accessory piece present. Testes and female genital tubes paired, opposed, outstretched; anterior testis much larger than posterior. Caudal glands and spinneret (?) absent.

Hab. Marine.

Genotype : C. exile Cobb, 1920.

Cobb, 1920, Contr. Sci. Nematol., ix, 251 and key.

40. Diplopeltis Cobb, in Stiles \& Hassall, 1905.

Syn. Dipeltis Cobb, 1891, nec Packard, 1885.

Cuticle very finely striated, with or without conspicuous bristles. Head with three lips, of which one is more pointed than the others, and spear-like. In the genotype there are four submedian rows of about twelve stout bristles on the neck. Lateral organs with a thickened margin, more pointed in front than behind and extending to the base of the lips. Buccal capsule very small, "seems to be armed with a minute labial spear" [see reference alrcady made to shape of lips]. Oesophagus club-shaped. Ocelli sometimes present. An accessory piece present, with a posterior process. Testes apparently paired and opposed. Female genital organs unknown. Caudal glands present. 
Hab. Marine.

Genotype: D. [Dipeltis] typicus (Cobb, 1891).

Cobb, 1S91, Proc. Limn. Soc. N.S.W., Sydney, vi, 155; Stiles \& Hassall, 1905, U.S. Dept. Agric., Bur. Anim. Indust. Bull. 79, 100, 101.

\section{Zygonemella Cobb, 1920.}

Cutiele coarsely striated, without bristles except in cervical region. Lateral alae apparently absent. Head with two erowns of bristles. Lips three, indistinct, faintly bilobed. Lateral organs transversely elliptical. Pharynx indistinguishable exeept for a slight posterior expansion of its hmen. Oesophagus without posterior bulb. Caudal end of male apparently without supplementary organs or papillae. Testes paired, opposed, reflexed; the anterior about twice as long as the posterior. Caudal glands and spimneret present. Female undescribed.

Hab. Marine.

Genotype: Z. striata Cobb, 1920.

Cobb, 1920, Contr. Sci. Nematol., ix, 247 and key.

42. Spirina Filipjev, 1918.

Syn. Spira Bastian, 1865, nec Brown, 1838.

Cutiele striated, with few bristles. Head not distinct, with bristles. Lateral organs circular, prominent or depresserl. No buccal cavity. Oesophagus short, considerably swollen behind, but withont distinct bulb. Cauclal end of male without papillae or supplementary organs. Two accessory pieces present. Female genital tubes paired, opposed. Spimneret small and indistinet.

Hab. Marine.

Genotype: S. [Spira] parasitifera (Bastian, 1865).

Bastian, 1865, Trans. Linn. Soc. London, xxv, 159; Filipjer, 1918, Trav. Lab. Zool., Stat. Biol. Sebastopal, Ser. II, No. 4, 232.

43. Nemanema Cobb, 1920.

Hearl without lips. Lateral organs apparently circular, connected with cutinized dncts. Buceal capsule exceedingly minute, conoid, "possibly with a forward pointing tooth." Oesophagus expands gradually behind. Caudal end of male with a few ventral preanal and postanal bristles. Female genital tubes paired, opposed, reflexed, the anterior branch rndimentary. Caudal glands present.

Hab. Marine (among sand and Algae).

Genotype: N. simplex Cobb, 1920.

Cobb, 1920, Contr. Sci. Nematol., ix, 230 and key. 
44. Disconema Filipjev, 1918.

Cuticle finely striated. Head without lips, but with six labial papillae, and ten bristles in a single erown. Lateral organs extremely large, oval, with some signs of concealed spirals. Buccal cavity absent. Oesophagus with indistinct bulb. Female genital tubes paired, ontstretehed.

Hab. Marine.

Genotype : D. alaima Filipjev, 1918.

Filipjev, 191S, Trav. Lab. Zool., Stat. Biol. Sebastopol, Ser. II, No. 4, 305.

\section{Prosphaerolaimus Filipjev, 1918.}

Cuticle finely striated. Head not distinet, with six lips and two crowus each of six papillae. Four cephalic bristles present, and behind these many supplementary bristles. Lateral organs large, eircular. "Oral cavity nearly absent"; [the figure does not enable us to form a conception of its structure]. Oesophagus cylindrical, without bulb or posterior swelling. Tail of female long and tapering. Female genital tube (single?) outstretched. Male apparently unknown.

Hab. Marine.

Genotype : P. eurypharynx Filipjev, 1918.

Filipjev, 1918, Trav. Lab. Zool., Stat. Biol. Sebastopol, Ser. II, No. $4,303$.

Appendix to Alamidale.

a. Linhomoella Cobb, 1920.

Cuticle finely striated, without bristles except towards the anterior end. Head not distinct, without apparent lips, but with a double crown of ten bristles. Lateral organs spiral. The presence of a pharynx is uncertain. Oesophagus cylindrical, without bulb. Candal end of male with a few bristles on each subventral line. Accessory piece present, with a small process. "As to supplementary organs, there are almost invisible ventral innervations." Testes and female genital tubes paired, opposed, outstretched. Caudal glands and spinneret present.

Hab. Marine.

Genotype: $L$. exilis Cobb, 1920.

Cobb, 1920, Contr. Sci. Nematol., ix, 254 and key.

b. Mastodex Steiner, 1921 (?).

Steiner (1921, Zool. Jahrb., Anat., xliii, 25) figures a worm under the name of Mastodex kerguelensis Stemer. The individual figured appears to be an immature one, with a simple, club-shaped oesophagus. No buccal cavity is indicated. 
Fam. 12. CHAETOSOMATIDAE Steiner, 1916. (Chactosomatiden Schepotieff, 1908).

Free-living (marine) forms, usually somewhat swollen in the middle region of the body. Cuticle, except at the extremities, transversely striated. Numerous bristles present, usually arranged in submedian rows. Lateral organs present, circular, horseshoe-shaped or spiral. On the ventral surface in the preanal region, in both sexes, there are two, three or four longitudinal rows of peculiar, tubular or solid, bristlelike "ambulatory" appendages. Lips not distinct. Six circumoral and numerous specialized ecphalic bristles present. A small pharynx apparently present. Oesophagus relatively short, muscular, with a posterior bulb and sometimes an anterior swelling or swellings. Male with two slender spicules and usually one or two accessory pieces. Male genital tube single, outstretched. Female genital tubes paired, opposed, reflexed. Caudal glands and spimeret present.

1. Chaetosoma Claparède, 1863.

Syn. Tristichochaeta Panceri, 1878.

Cephalic region swollen into an oval shape, and followed by a narrow "ncek." Oesophagus cylindrical, with a posterior bulb. Ventral appendages in two or three rows, tubular, postvulvar in female.

Hab. Marine.

Genotype: C. ophicephalum Claparède, 1863.

Claparède, 1863, Beobachtungen üb. Anat. u. Entwicklungsges. wirbelloser Thiere, etc., Leipzig, S8; Panceri, 187S, Atti R. Accad. Sci. Napoli, vii (10), 7 ; Stciner, 1916, Zool. Jahrb., Syst., xxxix, 560; Irwin-Smith, 1918, Proc. Linn. Soc. N.S.IV., Sydney, xlii, 757.

\section{Draconema Colsb, 1913.}

Closely resembles Chaetosoma, but the oesophagus is very short and has one or two anterior swcllings in addition to the posterior bulb. Ventral appendages in four rows, with free ends expanded.

Hab. Marine.

Genotype: D. cephalatum Cobb, 1913.

Cobb, 1913, Journ. Washington Acad. Sci., iii, 145; Steiner, 1916, Zool. Jahrb., Syst., xxxix, 560.

The differences between this genus and the last are very slight, and it seems possible that Draconema should be regarded as a synonym of Chaetosoma. 
3. Prochaetosoma nom. nov.

Syn. Rhabdogaster Metchnikoff, 1867, nec Loew, 1858.

Cephalic region not swollen, passing gradually into body. Body stouter in posterior half. Head without papillae. Oesophagus cylindrical, with well-developed posterior bulb, and sometimes an anterior swelling. Ventral appendages in two submedian rows, solid, somewhat hooked, extending in front of vulva, or entirely in front of it, in female. Male without aeccssory picce. A single large caudal gland present.

Hab. Marine.

Genotype : P. [Rhabdogaster] cygnoides (Metchnikoff, 1867).

Metchnikoff, 1867, Zeitschr.f. wiss. Zool., xvii, 542 ; Steiner, 1916, Zool. Jahrb., Syst., xxxix, 574; Stauffer, 1924, Zool. Jahrb., Syst., xlix, 119.

\section{Notochaetosoma Irwin-Smith, 1918.}

Cephalic region not swollen. Oesophagus cylindrical, faintly swollen behind. Ventral appendages in four rows, mostly jointed near the tip, eonfined to postvulvar rogion. An aceessory piece present. A single caudal gland present.

Hab. Marine.

Genotype : N. tenax Irwin-Smith, 1918.

Irwin-Smith, 1918, Proc. Linn. Soc. N.S.W., Sydney, xlii, 798.

Fam. 13. DESMOSCOLECIDAE Southern, 1914.

(Desmoscoleciden Schepotieff, 1908).

Stout, spindle-shaped, free-living forms. Body and tail cither with opaque transverse rings, or with numerous transverse rings or longitudinal rows of bristles. Head usually distinet, more or less rounded. Lateral organs present. Mouth circular or transversely elongate. Pharynx narrow, with thick cuticular lining. Oesophagus usually somewhat swollen bchind. Male with two spicules and one or two accessory picces. Testis single, reflexed. Female genital tubes paired, opposed. Eggs large and few, sometimes carried attached to the body of the parent.

\section{Desmoscolex Claparède, 1863.}

Syn. Quadricoma Filipjev, 1922.

Body and tail with opaque transverse rings, formed by a secretion to whieh foreign partieles beeome cemented, and with more or less pronounced clear interspaces. A few bristles present on the body, sometimes jointed and usually arranged in pairs. 
Hab. Marine.

Genotype: D. minutus Claparède, 1863.

Claparède, 1863, Beobachtungen üb. Anat. u. Entwicklungsges. wirbelloser Thiere, ete., Leipzig, 89 ; Schepotieff, 1908, Zeitschr.f. wiss. Zool., xc, 181; Stener, 1916, Zool. Anz., xlvii, 324; Filipjev, 1922, Act. Inst. Agronom. Stauropol., i (16), 150.

The chief character in which Quadricoma is said to differ from Desmoscolex is the larger number of annulations on the cuticle (seventeen or eighteen in Desmoscolex, thirty-three to seventy-six in Quadricoma, according to Filipjev). We are unable to accept this as a gencric character, and therefore regard Quadricoma as a symonym of Desmoscolex.

\section{Tricoma Cobb, 1894.}

Like Desmoscolex, but with the clear interspaces of euticle greatly reduced, almost the whole surface of the body being occupied by the opaque rings. Body with bristles in " eycles" of three in the genotype. Lips conical, flanked by cuticular "cephalic alae," and each bearing a bristle at its base.

Hab. Marine.

Genotype : $T$. cincta Cobb, 1894.

Cobb, 1894, Proc. Linn. Soc. N.S.W., Sydney, (2) viii, 389 ; Steiner, 1916, Zool. Anz., xlvii, 324; Filipjev, 1922, Act. Inst. Agronom. Stauropol., i (16), 155.

Cobb's description of the genotype was drawn up from memory, with the help of two drawings, the type having been lost. The genus is upheld by Filipjev, who has ascribed other species to it. The differences from Desmoscolex appear, however, to be very slight, and it is not improbable that Tricoma should be regarded as a synonym.

\section{Eudesmoscolex Steiner, 1916.}

Opaque rings on enticle, as in Tricoma, not separated by elear interspaces. Bristles in two subdorsal rows of nino each. Lips apparently absent.

Hab. Marine.

Genotype: E. oligochatus Steiner, 1916.

Steiner, 1916, Zool. Anz., xlvii, 324; 1916, Zool. Jahrb., Syst., xxxix, 579.

Here, again, the differenees from Desmoscolex are slight, and the genus appears of somewhat doubtful validity.

4. Greeffiella Cobb, 1922.

Syn. Trichoderma Greeff, 1869, nec Steph., 1835.

Head distinct, rounded, with two crowns of bristles. Lateral organs present. Cuticle of body very coarsely 
annulated, each ring bearing a circle of long, backwardlydirected, pointed bristles. Among these bristles there are a few stouter, tubular, subdorsal bristles resembling the ventral ambulatory appendages of the Chaetosomatidae. Lips not distinet. A mimute pharynx apparently present. Oesophagus with two slight swellings. Spicules very slender, straight. Aceessory piece apparently absent. Male genital tube single, reflexed. Female genital tubes paired, opposed, reflexed. Caudal glands and spinneret present.

Hab. Marine.

Genotype : $G$. [Trichoderma] oxycaudata (Greeff, 1869).

Greeff, 1869, Arch. f. Naturg., xxxv, i, 115; Cobb, 1922, Journ. Washington Acad. Sci., xii, 229 [Contr. Sci. Nematol., xii].

\section{Richtersia Steiner, 1916.}

Body short and stout. Head distinet, with lips (probably six), papillae and bristles, and followed by a cuticular "collar." Lateral organs spiral. Cuticle of body finely striated, with numerous longitudinal rows of fine, hook-like appendages, and short, scattered bristles. The "collar" bears five longer bristles. Pharynx narrow, with a peenliar "kink" in its walls posteriorly. Oesophagus thick and muscular, without bulb. Caudal end of male with preanal and postanal papillae. Spicules slender. A forked accessory piece present. Female genital tubes paired, opposed. Spimmeret present.

Hab. Marine.

Genotype : $R$. collaris Steiner, 1916.

Steiner, 1916, Zool. Jahrb., Syst., xxxix, 583.

\section{Fam. 14. ONCHOLAIMIDAE nov.}

Typically small, free-living forms with a buccal eavity having chitinoid walls and containing usually three teeth, of which one is dorsal and two subventral. One or more of the teeth may be absent, or additional teeth or dentieles may be developed. Oesophagus with or withont a posterior bulb.

This group is nearly co-extensive with the family Odontopharyngidae proposed by Micoletzky (1922). It contains a large and heterogeneous collection of genera, very difficult to arrange in a natural and satisfactory mamner. In Micoletzky's system the family Odontopharyngidae was divided into seven subfamilies (Ironinae, Enoplinae, Oncholaiminae, Microlaiminae, Chromadorinae, Anguillulinae and Diplogasterinae). On reviewing the whole of the genera, we have found it possible to retain the three first-mentioned subfamilies (their contents being somewhat altered), but 
have been unable to accept the remainder. The subfamily Anguillulinae contained only Anguillula and Macrolaimus, which seem to ns to fall more naturally into the family Rhabditidae (subfam. Rhabditinae). There seems to be nothing to prevent the contents of the subfamily Diplogasterinae also from being transferred to the same position in the system. The Mierolaiminae and Chromadorinae are so vaguely defined as to be ineapable of separation from each other or from the Oneholaiminae. On the other hand, there seems to be some justifieation for grouping together certain forms in which the pharynx contains only a single, frequently stylet-like, dorsal tooth, the other teeth characteristic of the family being absent. Aceordingly, we have placed these genera in a new subfamily, Desmodorinae.

As regards the family name, it is not in accordance with existing rules to take as the type of a family a genus which is not also the type of one of its subfamilies. We have therefore substituted the name Oncholaimidae for Odontopharyngidae.

The provisional classification here outlined is admittedly far from satisfactory. It is based chiefly upon the characters of the buccal cavity, which, in accordance with the plan adopted throughout the system, we have taken to be of primary importance. The groups, however, grade into each other almost impereeptibly, and it is possible to conneet them at various points with other families. In an ideal, or "natural," system of classification the genera would be better arranged in the form of a genealogical tree, and this would probably bear very little relation to the arbitrary and artificial system into which we have attempted to fit them.

\section{Subfam. 1. ONCHOLAIMINAE Micoletzky, 1922.}

Pharynx typically rather spacious, containing three teeth, frequently at or near its base. One or more of the teeth may be lost, or additional teeth may be developed on the walls of the pharynx. Oesophagus typically elub-shaped, exceptionally with a posterior bulb.

\section{Oncholaimus Dujardin, 1845.}

Syn. Viscosia de Man, 1890; Metoncholaimus Filipjev, 1918; Adoncholaimus Filipjev, 1918; Prooncholaimus Micoletzky, 1924.

Some speeies of relatively large size (25 to $30 \mathrm{~mm}$.). Cuticle unstriated, sometimes glutinons. Bristles usually present on the tail and papillae or bristles frequently present towards both extremities. Head not distinct, with rounded lips, and usually with bristles. Lateral organs transversely elliptical. 
Pharynx spacious, cylindrical or six-sided, containing a dorsal and two subventral tceth. One of the subventral teeth is larger than the others, and all the teeth carry the ducts of oesophageal glands. Oesophagus gradually swollen behind, without bulb. Ocelli sometimes present. A single accessory piece may be present. Testis single or paired. Female genital tubes paired, opposed, or single, anterior, always reflexed. A peculiar " tubiform organ" in the body-cavity of the female, opening by paired lateral pores near the anus. Caudal glands present. Specialized spinneret apparently absent.

Hab. Mostly marine, a few species in fresh or brackish water.

Genotype : Probably O. attenuatus Dujardin, 1845, according to Stiles and Hassall (1905).

Dujardin, 1845, Histoire naturelle des Helminthes, Paris, 230, 235; de Man, 1884, Die frei . . lebenden Nematoden der Niederl. Fauna, 67; Cobb, 1918, in Ward \& Whipple, Freshwater Biology, 487; Micoletzky, 1922, Arch. f. Naturg., Abt. A, lxxxvii, 331; Filipjev, 1918, Trav. Lab. Zool., Stat. Biol. Sebastopol, Ser. II, No. 4, 110 ; 1924, Zool. Anz., lviii, 108.

Viscosia is regarded by some authors (Micoletzky, 1922) as a subgenus of Oncholaimus. Its chief peculiarity appears to be the viscous nature of its cuticle, and this scarcely seems to warrant its separation from typical forms. Metoncholaimus is said by Filipjev (1918) to differ from Oncholaimus in having very long spicules and a "tubiform organ" of different structure. These points, however, scarcely appear to warrant a generic distinction. We have been unable to find any satisfactory characters in Filipjev's (1924) diagnosis to justify the separation of Adoncholaimus. Prooncholaimus Micoletzky is equally unsatisfactory.

\section{Paroncholaimus Filipjev, 1916.}

According to Filipjev this genus differs from Oncholaimus in the following characters. Of the teeth in the pharynx the two subventral are symmetrical and larger than the dorsal. In the female, a "tubiform organ" is absent.

Hab. Marine.

Genotype : P. [Oncholaimus] vulgaris (Bastian, 1865).

Bastian, 1865, Trans. Linn. Soc. London, xxv, 135; Filipjev, 1916, Ann. Mus. Zool. Acad. Imp. Sci., Petrograd, xxi, 105.

3. Oncholaimellus de Man, 1890.

Head with ten bristles. Pharynx elongatc, its anterior third separated by a constriction from the posterior part, 
which is funnel-shaped. The large tooth is very well developed, occupying almost the whole lumen of the pharynx. It is asymmetrieal (subventral), as in Oncholaimus. The remaining two teeth are blunt tubereles. Oesophagus slightly swollen behind. Candal end of male with alae and three pairs of fine sublateral bristles, one pair preanal and two postanal. Botl preanal and postanal papillae present. Spienles long, unequal, the longer (right) slightly S-shaped, the other only slightly curved and two-thirds of the length of the right. Female genital tubes paired, opposed, reflexed. "Tubiform organ" absent. Caudal glands and spinneret present.

Hab. Marine.

Genotype: O. calvadosicus de Man, 1890.

de Man, 1890, Mém. Soc. Zool. France, iii, 189.

\section{Mononchulus Cobb, 1917.}

Cuticle unstriated and apparently without bristles. Head not distinet, with six lips and six papillae, but without bristles. Lateral organs very ineonspienous, semieireular. Pharynx large, with three teeth, of whieh one of the subventral is considerably the largest. Oesophagus comparatively long, somewhat swollen posteriorly. Apparently hermaphrodite, the anterior branch of the genital tube longer and reflexed, and functioning as a female organ; the posterior braneh small, outstretched, producing spermatozoa. Spinneret opens ventrally and subterminally.

Hab. Fresh water.

Genotype: $M$. ventralis Cobb, 1918.

Cobb, 1917, Soil Science (May), 447, 453; 1918, Contr. Sci. Nematol., vii, 195.

5. Rhabdodemania nom. nov.

Syn. Demania Southern, 1914, nec Laurie, 1906, nec Steiner, 1914.

Cutiele smooth. Head with ten bristles in one or two erowns. Lateral organs indistinct. Pharynx large and deep, the hinder portion having three longitudinal chitinoid rods, each with an anterior tooth. All the teeth are apparently of equal size. Oesophagus slightly swollen posteriorly. Candal end of male withont preanal papillae or supplementary organs. Spicules equal. An aceessory pieee present. Female genital tubes paired, opposed, reflexed. Caudal glands present.

Hab. Marine.

Genotype: D. major Southem, 1914 (by page precedence).

Southern, 1914, Proc. R. Irish Acad., xxxi, 41. 


\section{Gammanema Cobb, 1920.}

Cutiele rather finely striated, without bristles exeept near the extremities. Head not distinet, with six short labial bristles and six longer, jointed eephalic bristles. There are apparently twelve lips, joined by a membrane with various anterior appendages, the whole resembling a leaf-erown. Twelve of the appendages are longer than the others and have spatulate terminations. Lateral organs unkuown. Pharynx wide, shallow and eup-shaped, with three inwardlypointing teeth at its base. From the base of the pharynx extend three ehitinoid rod-like struetures, eomnected with the museulature of the oesophagus. Oesophagus diminishes in diameter behind, without bulb. Caudal end of male with at least sixtcen small preanal supplementary organs, and a few submedian bristles near the anus. Spieules slender. Aecessory pieces apparently two, "obseure." Testes paired, opposed, outstretehed. Female genital tube single, posterior, reflexed. Caudal glands and spinneret present.

Hab. Marine.

Genotype: G. ferox Cobb, 1920.

Cobb, 1920, Contr. Sci. Nematol., ix, 291 and key.

7. Spilophora Bastian, 1865.

Syn. Spiliphera Bastian, 1865; Hypodontolaimus de Man, 1856; Halichoanolaimus de Man, 1886; Trogolaimus Cobb, 1920 .

Cuticle striated. Head not distinet, without apparent lips, but with bristles. Lateral organs spiral. Pharynx more or less cup-shaped, with longitudinal folds anteriorly and three ehitinoid processes extending baekwards from its base into the walls of the oesophagus. Oesophagus somewhat swollen behind, sometimes with a bulb.

Hab. Marine or fresh water.

Genotype : S. elegans Bastian, 1865.

Bastian, 1865, Trans. Linn. Soc. London, xxv, 165, 178; Steiner, 1916, Zool. Jahrb., Syst., xxxix, 523.

Steiner (1916) eonsiders it doubtful whether Spilophora ean be distinguished from Chromadora. He refers to the fact that three posterior processes of the pharyngeal wall are mentioned by Bastian in his deseriptions of both genera. A study of Bastian's figures shows, however, that the processes in Spilophora are quite different in nature from those in Chromadora, the latter appearing simply as thickenings of the posterior part of the pharyngeal wall. On this account we have retained Spilophora as a distinct genus, although on many points the deseription of the genotype is ineomplete.

SYN. NEM. 
Hypodontolaimus, which was considered by Steiner (1916) as a possible synonym of Chromadora, can be regarded as a synonym of Spilophora on account of de Man's description of similar posterior pharyngcal processes. It appears very donbtful whether Trogolaimus can be separated from Spilophora.

8. Cobbionema Filipjev, 1922.

Cuticle smooth, with rows of internal dots. Head not distinet, with six (?) small lips and some slender bristles. Lateral organs large, spiral. Pharynx with a cup-shaped anterior portion and a funnel-shaped posterior portion. The former is surrounded by circular muscles. The latter contains three longitudinal chitinoid thickenings, each bearing at its anterior end several small teeth, irregularly arranged. Oesophagus with an anterior swelling, and somewhat swollen posteriorly, but without bulb. Male undescribed. Female genital tubes paired. Tail of female sharply constricted a little behind the anus. Spinneret present.

Hab. Marine.

Genotype: C. acrocerca Filipjev, 1922.

Filipjer, 1922, Act. Inst. Agronom. Stauropol., i (Zool.), 16,114 .

\section{Bolbella Cobb, 1920 .}

Cuticle very finely transversely striated, and also longitudinally striated, with some fine bristles towards the extremities. Head not distinet, truneate, with six circumoral papillae and a single erown of ten bristles (two single, lateral, and four submedian pairs). Lateral organs stirrupshaped, with transversely elliptical anterior opening. Pharynx in two portions, the anterior slightly wider than the posterior. The latter contains three teeth, the dorsal and left subventral teeth small, the right subventral elongate and spearlike, extending forward into the anterior chamber of the pharynx. Oesophagus long, with a slender anterior portion and a stouter posterior portion consisting of a series of rounded bulbs. Candal end of male with two cup-shaped preamal supplementary organs. Accessory piece (? pieces) with long posterior process. Testes paired, opposed, outstretcherd. Female genital tubes paired, opposed, reflexed. Caudal glands (preanal) and spimmeret present.

Hab. Marine (in sand).

Genotype: B. tenuidens Cobb, 1920.

Cobb, 1920, Contr. Sci. Nematol., ix, 308 and key.

10. Polygastrophora de Man, 1922.

Cuticle unstriated but with bristles. Head slightly distinct. Twelve cephalic bristles present. Mouth probably 
surrounded by papillae. Lateral organs unknown. Buecal cavity large, shaped somewhat as in Symplocostoma, with one large and two small anteriorly-directed teeth. Oesophagus gradually swollen behind, with a series of bulb-like expansions. Caudal end of male with a median series of preanal papillae. A slender accessory piece present, almost half as long as the spicules, its lateral portions rumning out proximally into a semicircular, anteriorly-direeted hook. Female unknown. Caudal glands present.

Hab. Marine.

Genotype: $P$. attenuata de Man, 1922.

de Man, 1922, Tijdschr. Ned.dierk. Vereen., Leiden, (2) xviii, 131.

\section{Eurystomina Filipjev, 1921.}

Syn. Eurystoma Marion, 1870, nec Rafinesque, 1818; Amphistenus Marion, 1870; Marionella Cobb, 1922.

Cuticle covered with very short, scattered bristles. Head truncate, with a crown of long, slender bristles. Lateral organs unknown. Pharynx spacious, armed with three chitinoid rods, eaeh bearing a tooth anteriorly. Oesophagus relatively long, slightly swollen posteriorly. Two ocelli present. Caudal end of male with two large preanal supplementary organs. An accessory piece, with a long posterior process, present. Testes paired, opposed, outstretched. Female genital tubes paired, opposed, reflexed. Caudal glands and spinneret present or absent.

Hab. Marine.

Genotype : E. [Eurystoma] spectabile (Marion, 1870).

Marion, 1870, Ann. Sci. Nat., Paris, Zool., xiii, 14, 19; Filipjev, 1921, Trav. Lab. Zool., Stat. Biol. Sebastopol, Ser. II, No. 4, 568; Cobb, 1922, Contr. Sci. Nematol., xi, 353.

We have included Amphistenus tentatively in the synonymy of this genus. The males of the two species deseribed by Marion are still unknown. Cobb (1922) gives a somewhat different account of the structure of the pharynx from that given above, but as he designates Eurystoma spectabile Marion as genotype of Marionella, this is a synonym of Eurystomina.

\section{Phanoderma Bastian, 1865.}

Cuticle very transparent, unstriated or with longitudinal markings. Head with bristles. Pharynx indistinct, with obscure indications of three thickenings. Oesophagus swollen behind, not distinctly muscular. Two large ocelli present. Caudal end of male with a small supplementary organ. No accessory piece. Female genital tubes paired, opposed. Caudal glands and spinneret present. 
Hab. Marine.

Genotype: P. cocksi Bastian 1S65, aceording to Stiles \& Hassall (1905).

Bastian, 1865, Trans. Linn. Soc. London, xxv, 142.

13. Anaxonchium Cobb, 1920.

Cuticle rather eoarsely striated, withont bristles. Lateral alae present. Head not distinet, with a erown of ten short, stont, two-jointed bristles. Lips apparently six, bilobed, eaeh bearing externally a short bristle and two longer appendages with expanded ends (aeeording to the figure, with which the deseription does not altogether agree). Lateral organs "peculiar, large, faint" (according to figure, ineipient spirals). Pharynx narrow, largely oceupied by a well-developed dorsal tooth. Opposite to this several smaller teeth, of whieh two subventral ones are probably the largest. Apparently small dentieles also oeeur dorsally to and in front of the large clorsal tooth. Oesophagus without posterior bulb. Male with a series of fifteen to twenty preanal supplementary organs and a few small eaudal bristles. Spieules rather broad. Two "somewhat shoe-shaped" aeeessory pieees present, with a median piece between and behind them. Testis single, anterior, reflexed. Female nnknown.

Hab. Marine (in sand).

Genotype: A. litorium Cobb, 1920.

Cobb, 1920, Contr. Sci. Nematol., ix, 319 and key.

\section{Thoönchus Cobb, 1920.}

Cutiele finely striated. Head not distinet, with six lips, six papillae and ten bristles. Lateral organs apparently transversely elliptieal. Pharynx rather widle, goblet-shaped, containing a ratler small dorsal tooth and two subventral teeth at its base. In front of these teeth the walls of the pharynx bear numerous small dentieles. Oesophagus gradually swollen behind, without bulb. Caudal end of male with a single preanal supplementary organ in the form of a transverse ridge, a pair of subventral preanal papillae, and a few short preanal and postanal bristles. Spieules rather stout. Aceessory pieee (? single) with expanded lower end in which spieules slicle, and without posterior process. Testes paired, opposed, outstretehed. Female genital tubes paired, opposed, reflexed. Caudal glands (preanal) and spinneret present.

Hab. Marine.

Genotype: 'T. ferox Cobb, 1920.

Cobb, 1920, Contr. Sci. Nematol., ix, 310 and key. 
15. Mononchus Bastian, 1865.

Syn. Onchulus Cobb, 1920; Promononchus Mieoletzky, 1923.

Cuticle mnstriated and without bristles. Head not distinet, with or without papillae, without bristles. Lateral organs small, indistinet. Pharynx large, more or less oval, with a dorsal tooth projecting from its wall into the lumen, and frequently with two smaller subventral teeth. Small denticles may also be present on the ventral wall of the pharynx. Oesophagus without bulb, but slightly swollen posteriorly. Caudal end of male with a ventral row of eight to twenty supplementary organs, and with preanal and postanal papillae. Two accessory pieces present. Testes paired, opposed, outstretched. Female genital tubes usually paired, opposed, reflexed. Many species probably hermaphrodite. Caudal glands and spinneret present.

Hab. Soil or fresh water.

Genotype : M.truncatus Bastian, 1865.

Bastian, 1865, Trans. Linn. Soc. London, xxv, 100; Cobb, 1916, Journ. Parasitol., ii, 196; 1917, Soil Science (May), 184, ff. [Contr. Sei. Nematol., vi, 129, ff.].

Onchulus Cobb and Promononchus Micolctzky were both described from single immature specimens, and are insufficiently characterized to separate them from Mononchus.

Cobb (1916 and 1917) divides the genus Mononchus into the following subgenera :

a. Mononchus.

Dorsal tooth large, midway or further forward in the pharynx. Subventral teeth present or absent. Ventral denticles absent. Type : truncatus Bastian, 1865.

b. Prionchulus Cobb, 1916.

Dorsal tooth large, midway or further forward in the pharynx. Subventral teeth apparently absent. Ventral denticles arranged longitudinally. Type: muscorum Dujardin, 1845.

c. Anatonchus Cobb, 1916.

Dorsal tooth and subventral teeth small and backwardly-directed, at about the middle of the pharynx or behind it. Denticles apparently absent. Type: tridentatus de Man, 1876.

d. Iotonchus Cobb, 1916.

Dorsal tooth always at the base of the pharynx. The subrentral teeth may be very small. Ventral denticles apparently absent. Type : gymnolaimus Cobb, 1893. 
e. Mylonchulus Cobb, 1916.

Dorsal tooth large, midway or further forward in the pharynx. Subventral teeth frequently present. Ventral denticles numerous, arranged in transverse rows or on two rasp-like areas. Type : minor Cobb, 1893.

f. Sporonchulus Cobb, 1917.

Dorsal tooth as in Mylonchulus. Subventral teeth apparently absent. Ventral dentieles irregularly arranged. Type (by page precedence): dentatus Cobb, 1917.

16. Oionchus Cobb, 1913.

Cuticle finely striated, without bristles or lateral alae. Lateral organs stirrup-shaped. Head without bristles. Lips indistinct. Two erowns of eephalic papillae present. Buecal cavity narrow, cylindrical or prismatie, almost completely filled by a dorsal spear-like tooth. Oesophagus cylindrical, without bulb. Male nnknown.* Female genital tube single, anterior, reflexed. Tail short. Spinneret present.

Hab. Soil, about roots of grass.

Genotype: O. obtusus Cobb, 1913.

Cobb, 1913, Journ. Washington Acad. Sci., iii, 442 and key; 1917, Soil Science, 453; 1918, in Ward \& Whipple, Freshwater Biology, 487; Mieoletzky, 1922, Arch.f. Naturg., Abt. A, lxxxvii, 367.

\section{Udonchus Cobb, 1913.}

Cuticle finely striated, without lateral alae. Latcral organs transversely elliptical. Head rounded, without bristles. Lips with two cireles of papillae. Buecal cavity cup-shaped in front, somewhat narrowed behind, containing a small forwardly-rlirected dorsal tooth at the base of the eup-shaped portion, and opposite to this a very minute ventral tooth. Ocsophagus with a posterior bulb. Male unknown. Tail of female elongate, slightly swollen at the tip. Spinneret present. Female genital tube single, anterior, reflexed.

Hab. Fresh water.

Genotype: U.tenuicaudatus Cobb, 1913.

Cobb, I9I3, Journ. Jashington Acad. Sci., iii, 442 and key; Micoletzky, 1922, Arch.f. Naturg., Abt. A, lxxxvii, 368.

\section{Odontopharynx de Man, 1912.}

Cuticle very finely striated, without bristles. Head with papillae but without lips or bristles. Lateral organs transversely elliptical. Pharynx spacious, longer than wide, hexa-

* Cobb (1918) states that the male has a "bursa" and unequal or equal spieules. 
gonal anteriorly, three-sided posteriorly, containing a large dorsal tooth and several much smaller teeth, some lateral, some subventral. Oesophagus with cylindrical, muscular anterior portion, and a non-muscular posterior portion which is narrower anteriorly than the former, but expands gradually behind. No oesophageal bulb. Caudal end of male with preanal and postanal papillae. "Probably" two equal spicules and an accessory piece present. Female genital tubes paired, the posterior short and without ovary.

Hab. On diseased Hyacinth bulbs.

Genotype : O. longicaudatus de Man, 1912.

de Man, 1912, Zool. Jahrb., Syst., xxxiii, 637.

19. Alaimonema Cobb, 1920.

Cuticle finely striated, with scattered, inconspicuous bristles. Head not distinct, with four crowns each of four bristles. Lips indistinct. Lateral organs large, spiral. Pharynx very narrow, apparently three-sided, containing three small, subequal teeth towards its anterior end. Oesophagus with a pyriform posterior bulb. Caudal end of male with thirty. seven prominent preanal supplementary organs. A slender accessory piece present. Testis single, anterior, outstretched. Female unknown.

Hab. Marine (in sand).

Genotype : A. multicinctum Cobb, 1920.

Cobb, 1920, Contr. Sci. Nematol., ix, 327 and key.

20. Aponchium Cobb, 1920.

Cuticle unstriated, apparently without bristles. Head very slightly distinct, with six labial papillae and a single crown of four bristles. Lateral organs circular. Pharynx small, its cavity almost filled by three forwardly-directed teeth, of which the dorsal is apparently smaller than the two subventral. Oesophagus with an elongated, pyriform, bulblike posterior swelling. Caudal end of male with twelve highly-developed preanal supplementary organs having paired, spiny, shallow, cup-shaped ends. Spicules slender. Two accessory pieces present, with postcrior processes, and also a median piece between the spicules. Testis single, anterior, reflexed. Female genital tube single, anterior, outstretched. Caudal glands and spinneret present.

Hab. Marine.

Genotype : A. cylindricolle Cobb, 1920.

Cobb, 1920, Contr. Sci. Nematol., ix, 298 and key. 


\section{Catanema Cobb, 1920.}

Cuticle finely striated. Head with ten bristles, of which four are longer than the rest and three-jointed. Lateral organs minute, directed forwards. Pharynx narrow, containing anteriorly several (? six) small teeth. Oesophagus with a posterior bulb. Candal end of male with one small preanal supplementary organ, precerled by a number of minute ventral bristles. Seven pairs of subventral postanal supplementary organs also present. An accessory picee (? two accessory pieces) present, with posterior process. Testis single, anterior, outstretched. Female undeseribed. Candal glands and spinneret present. Genus apparently based on a single male specimen.

Hab. Marine (in sand).

Genotype : C. exile Cobb, 1920.

Cobb, 1920, Contr. Sci. Nematol., ix, 271 and key.

22. Pseudobathylaimus Filipjev, 1918.

Syn. Bathylaimus Daday, 1905, nec Cobb, 1894, nec Ditlevsen, 1919; Dadayia Micoletzky, 1922, nec Travassos, 1921.

Cuticle markedly striated, withont bristles. Head not distinct, without lips but with four or six bristles. Lateral organs unknown. Pharynx usually long, in two portions, the anterior with tooth-like structures, the posterior with longitudinal ribs. Oesophagus with a posterior bulb. Two or four rows of ocelli present. Caudal end of male, in the genotype, with numerous preanal supplementary organs. Two accessory pieces present. Female genital tubes paired, opposed, ontstretched; or mpaired, anterior. Caudal glands and spinneret present.

Hab. Fresh water.

Genotype: P. [Bathylaimus] maculatus (Daday, 1905).

Daday, 1905, Zoologica, Stnttgari, xviii, 59; Filipjev, 1918, Trav. Lab. Zool., Stat. Biol. Sebastopol, Ser. II, No. 4, 347 ; Micoletzky, 1922, Arch.f. Naturg., Abt. A, lxxxvii, 328.

\section{Croconema Cobb, 1920.}

Cutiele thick, coarsely striated, with many short, slightlycurved bristles. Head slightly swollen, apparently covered by a single helmet-like cap of cuticle, bearing at least six irregular longitudinal rows of bristles. Apparently twelve small lips present. Lateral organs small, spiral. Pharynx narrow, nearly as long as the eephalic eap, its lumen nearly filled by the apices of teeth, of which one dorsal and one larger, submedian, have been made out. Oesophagus gradually swollen behind, without bulb. Hale nnknown. Female 
genital tubes paired, opposed, reflexed. Caudal glands and spinneret present.

Hab. Marine.

Genotype: C. cinctum Cobb, 1920.

Cobb, 1920, Contr. Sci. Nematol., ix, 332 and key.

24. Cylicolaimus de Man, 1889.

Cuticle unstriated, with lateral and submedian bristles. Head not distinct, with three small lips and a crown of bristles. Lateral organs very small, transversely elliptical. A series of glands present in each lateral field. Pharynx relatively wide, surrounded externally by a secondary chitinoid ring, and with three forwardly-projecting tooth-like processes at its base, through which the oesophageal glands open. There may be a crown of denticles within the mouth-opening, and behind these three larger teeth. In addition there may be two or more forwardly-pointing triangular plates projecting from the wall of the pharynx. Oesophagus gradually swollen behind, without bulb. Caudal end of male with numerous preanal and postanal bristles and a median preanal papilla (? supplementary organ). Spicules short and broad. Accessory piece composed of two lateral portions, each with a posterior process. 'Testes paired, opposed, outstretched. Female genital tubes paired, opposed, reflexed. Caudal glands and spinneret present.

Hab. Marine.

Genotype : C. [Leptosomatum] magnus (Villot, 1875).

Villot, 1875, Arch. Zool. exp. et gén., Paris, iv, 458; de Man, 1889, Mém. Soc. Zool. France, ii, I; Jägerskiöld, 1901, K. Svensk. Vetensk. Acad.Handl., Stockholm, xxxv, 5 ; Southern, 1914, Proc. R. Irish Acad., xxxi, 39.

\section{Synonchus Cobb, 1894.}

Cuticle finely striated, with short bristles, especially anteriorly, where they occur in bundles. Head truncate, with ten bristles (two single lateral, four submedian pairs). Three rather indistinct lips. Pharynx small, containing a prominent dorsal tooth and two rudimentary subventral teeth. Oesophagus gradually swollen behind. Caudal end of male with a single preanal supplementary organ and irregular subventral rows of preanal and postanal bristles. Spicules equal, slender. Accessory pieces (? two) with long posterior process. Female genital tubes paired, reflexed. No "tubiform organ." Caudal glands present.

Hab. Marine.

Genotype: S. fasciculatus Cobb, 1894.

Cobb, 1894, Proc. Linn. Soc. N.S.W., Sydney, (2) viii, 411. 
26. Microlaimus de Man, 1880.

Cuticle striated, withont bristles or alae. Head distinct, knob-like, withont lips and usually without bristles. Cephalie papillae usually indistinet. Lateral organs eireular. Pharynx narrow, goblet-shaped or eylindrieal, containing a small tooth on its dorsal wall, and sometimes two smaller subventral teeth. Oesophagus with a posterior bulb. Caudal end of male without papillae or supplementary organs. Two rodshaped aecessory pieces present. Female genital tubes typieally paired, opposed. Caudal glands and spinneret present.

Hab. Soil, or fresh or brackish water.

Genotype: M. globiceps de Man, 1880.

de Man, 1880, Tijdschr. Nederl, dierk. Vereen., Leiden, 15; 1854, Die frei.. lebenden Nematoden der Niederl. Fauna, 51 ; Steiner, 1916, Zool. Jahrb., Syst., xxxix, 590; Micoletzky, 1922, Arch.f. Naturg., Abt. A, lxxxvii, 371.

27. Odontobius Roussel de Vauzème, 1834.

Cuticle extremely finely, if at all, striated, withont bristles. Head not distinet, with four (? six) very small bristles. Lateral organs ineipient spirals. Pharynx goblet-shaped, rather wider than deep, with three small, blunt teeth at its base and a single tooth in its dorsal (?) wall. Oesophagus gradually swollen behind, without bulb. Tail of male with three pairs of postanal papillae. Spieules flattened dorsoventrally. An accessory piece, with large posterior process, present. Testis apparently single, outstretehed. Female genital tube single, anterior, outstretched. Caudal glands and spinneret doubtfully present.

Hab. Genotype on baleen-plates in mouth of whales. Certain free-living marine species have been attributed to the genus, probably erroneously.

Genotype: O. ceti Roussel de Vauzème, 1834.

Roussel de Vauzème, 1834, Ann. Sci. Nat., Paris, Zool., i, 326 ; Bastian, 1865, Trans. Linn. Soc. London, $\mathrm{xxv}, 161$; Baylis, 1923, Ann. Mag. Nat. IIist., (9) xii, 617.

28. Chromaspira Filipjev, 1918.

Syn. Chromaspirina Filipjer, 1918.

Cutiele striated. Head rounded, not distinet, with three erowns of short bristles. Oral opening surrounded by a slightly projecting entieular wall. Lateral organs ineipient spirals. Pharynx with a relatively wide anterior portion, with folded walls, and eontaining a large dorsal tooth and two small subventral teeth, and a narrower posterior portion 
passing into the lining of the oesophagus. Oesophagus gradually swollen behind, without bulb. Spicules broad, membranous. Accessory piece complex. Testis single. Female genital tubes paired, reflexed.

Hab. Marine.

Genotype: C. pontica Filipjev, 1918.

Filipjev, 1918, Trav. Lab. Zool., Stat. Biol. Sebastopol, Ser. II, No. 4, 213, 229.

\section{Rhips Cobb, 1920.}

Cuticle eoarsely striated, with rod-like or basketwork-like ornamentation. Head not distinet, apparently with six very small, double lips. Six labial papillae and ten cephalie bristles present. At the level of the latter there are also four shorter sublateral "seales " or "horns." Lateral organs transversely elongate. Pharynx small, eontaining an anteriorly-directed dorsal tooth and "one or two" minute subventral teeth. Oesophagus somewhat swollen behind. Caudal end of male probably with a series of preanal supplementary organs. Spicules eomposed of two eurved sections jointed together end to end, the posterior seetion shorter than the anterior. Five aceessory piees present, two in front of the spicules and three behind them. Testis single, anterior, ontstretehed. Female genital tubes paired, opposed, reflexed. Caudal glands and spinneret present.

Hab. Marine.

Genotype : R. ornata Cobb, 1920.

Cobb, 1920, Contr. Sci. Nematol., ix, 339 and key.

\section{Linhomoeus Bastian, 1865.}

Cuticle finely striated, with bristles, especially anteriorly. Head not distinet, without apparent lips but with bristles. Lateral organs small, eircular. Oral eavity widening behind into a shallow pharynx which may or may not be armed with teeth at its base. Oesophagus somewhat swollen posteriorly, without bulb. Caudal end of male apparently without papillae, but with two preanal supplementary organs. Testes paired and opposed, or single. An acessory piece present, with two posterior proeesses. Female genital tubes paired, opposed (exeeptionally single), reflexed. Caudal glands and spinneret present.

Hab. Marine.

Genotype: L. hirsutus Bastian, 1865.

Bastian, 1865, Trans. Linn. Soc. London, xxv, 154; de Man, 1889, Mém. Soc. Zool. France, ii, 207 ; 1907, Tijdschr. Nederl. 
dierk. Vereen., Leiden, (2) x, 239; 1907, Mém. Soc. Zool. France, $\mathrm{xx}, 74$.

de Man (1907) has proposed the subgenera Eulinhomoeus and Paralinhomoeus. In the former the tail is cylindrical and the pharynx is armed with teeth (type: elongatus Bastian, 1865). In the latter the tail is attenuated and the pharynx nurmed (type: lepturus de Man, 1907).

\section{Metalinhomoeus de Man, 1907.}

Aceording to de Man, this genus closely resembles his subgenus Paratinhomoeus of Linhomoens. It is to be distinguished by the faet that the oesophagus terminates in a bulb with a valvular apparatus.

Hab. Marine.

Genotype: M. typicus de Man, 1907.

de Man, 1907, Tijdschr. Nederl. dierk. Vereen., Leiden, (2) x, 241; 1907, Mém. Soc. Zool. France, xx, 81.

\section{Cothonolaimus Ditlevsen, 1919.}

Syn. Macrolaimus Ditlevsen, 1919, nec Maupas, 1900.

Cuticle thin, unstriated. Head with two crowns of bristles, six small in the anterior erown and four stout and twice as long in the posterior. Lateral organs incipient spirals. Buceal capsule very large, thin-walled, eonstrieted transversely into two parts, the anterior larger and fumel-shaped, with minute teeth at its base, the posterior globular, with still smaller teeth in its middle. Oesophagus almost eylindrical throughont. Spicules rather slender. Aceessory picee large and dark-eoloured, with two long and slender posterior processes. Testis single. Female genital tubes paired, opposed, reflexed. Caudal glands present.

Hab. Marine.

Genotype: C. [Macrolaimus] inermis (Ditlevsen, 1919) (by page precedence).

Ditlevsen, 1919, Vid. Medd. Naturh. Foren., Copenhagen, $1 \times x, 188,299$.

\section{Comesoma Bastian, 1865.}

Syn. Sabatieria de Rouville, 1903; Parasabatieria de Man, 1907.

Cuticle finely striated, apparently without bristles except towards the extremities. Head more or less distinct, truneate, without apparent lips, but with papillae and two erowns of bristles. Lateral organs spiral or eircular. Pharynx very small, typieally three-sided, with a dorsal and two subventral teeth at its base. Oesophagus somewhat swollen posteriorly, 
without bulb. Candal end of male with submedian preanal and postanal bristles. Accessory piece single, bipartitc. Testes paired. Female genital tubes paired, opposed, outstretched. Caudal glands and spinneret present.

Hab. Marine.

Genotype : C. vulgare Bastian, 1865.

Bastian, 1865, Trans. Linn. Soc. London, xxv, 158; de Man, 1890, Mém. Soc. Zool. France, iii, 171; 1907, Tijdschr. Nederl. dierk. Vereen., Leiden, x, 237; 1907, Mém. Soc. Zool. France, $\mathrm{xx}$, 66; de Rouville, 1903, Compt. rend. Soc. Biol., Paris, Iv, 1529; Cobb, 1914, Contr. Sci. Nematol., i, 14; Southern, 1914, Proc. R. Irish Acad., xxxi, 25.

Sabatieria, apart from the question whether teeth exist in its pharynx, which none of the observers scems to have been able to determine, appears to differ from the type of Comesoma only in having an accessory piece with a postcrior process. Parasabatieria, again, differs from Sabatieria only in the presence of a series of preanal supplementary organs in the male. In view of the uncertainty regarding the presence of teeth, and the slight nature of the other differences, we prefer for the present to regard both these genera as synonyms of Comesoma.

\section{Dagda Southern, 1914.}

Cuticle finely striated. Head separated from body by a constriction, with rounded labial papillae and a single crown of four bristles. Lateral organs incipient spirals. Pharynx small, funnel-shaped, containing a dorsal and two subventral teeth. Oesophagus gradually swollen behind, without bulb. Candal end of male with eleven median preanal supplementary organs. Accessory piece with two rounded posterior processes. Testis single. Caudal glands present. Female unknown. Description of genotype based on a single specimen.

Hab. Marine (in sand).

Genotype: D. bipapillata Southern, 1914.

Southern, 1914, Proc. R. Irish Acad., xxxi, 29.

\section{Cyatholaimus Bastian, 1865.}

Syn. Achromadora Cobb, 1913; Nannonchus Cobb, 1913; Pomponema Cobb, 1917; Paracyatholaimus Micoletzky, 1922 (as subgenus).

Cuticle striated, apparently without bristles. Head with six indistinct lips and inconspicuous papillae. Six to ten cephalic bristles present. Lateral organs usually present, spiral or circular. Pharynx cup-shaped, with longitudinal thickenings in its wall anteriorly. A dorsal tooth almost always well developed, and not infrequently ventral or sub- 
ventral teeth are also present in a recess in the pharyngeal wall. Oesophagus usually without a bulb.* Oeelli present in marine forms. Caudal end of male with or without papillae, and occasionally with supplementary organs. Four accessory pieces, in two pairs, present. Testis single or paired. Female genital tubes paired, opposed, reflexed. Caudal glands and spinneret usually present.

Hab. Marine, in brackish or fresh water, or in soil.

Genotype: C. ocellatus Bastian, 1865.

Bastian, 1865, Trans. Linn. Soc. London, xxv, 162; Cobb, 1913, Journ. Washington Acad. Sci., iii, 434; 1917, Contr. Sci. Nematol., v, 118; 1918, in Ward \& Whipple, Freshwater Biology, 489; Micoletzky, 1922, Arch. f. Naturg., Abt. A, lxxxvii, $375,377$.

We have ineluded eertain genera and subgenera in the synonymy of Cyatholaimus owing to their insuffieient characterization.

36. Chromadora Bastian, 1865.

Syn. Acanthopharynx Marion, 1870 (?); Ethmolaimus de Man, 1880; Euchromadora de Man, 1886; Graphonema Cobb, 1898; Chromadorissa Filipjev, 1917; Spilophorella Filipjev, 1917 ; Chromadorina Filipjev, 1918; Chromadorella Filipjev, 1918; Spilipherella Filipjev, 1918; Odontocricus Steiner, 1918; Polysigma Cobb, 1920; Ptycholaimellus Cobb, 1920; Chromadorita Filipjev, 1922; Prochromadora Filipjev, 1922; Endolaimus Filipjev, 1922.

Cuticle striated, usually with submedian bristles. Lateral alae usually absent, except in marine forms. Hear without lips, but with six to twelve papillae. Submedian cephalie bristles usually present, lateral eephalie bristles absent. Lateral organs in the form of grooves or transversely oval, rarely definitely spiral. Pharynx typically in two portions, the anterior wide, the posterior funnel-shaped. The anterior portion has longitudinal rod-like thickenings (or folds?) in its wall, and usually contains a dorsal tooth, and sometimes two subventral teeth. Oesophagus with a more or less distinet posterior swelling, but usually without a bulb. Caudal end of male with or without preanal papillae. Postanal papillae absent. Spieules sometimes mequal and dissimilar. Aceessory piece complex, consisting of a posterior, a median, and two lateral portions. Testis usually single. Female genital tubes paired, opposed, reflexed. Caudal glands present. Spinneret present or absent.

* According to Cobb there is no oesophageal bulb. Micoletzlyy, however, states that a bulb is usually present. The species figured by Bastian do not appear to possess bulbs. 
Hab. Marine, in fresh water, or in soil.

Genotype : C. vulgaris Bastian, 1865.

Bastian, 1865, Trans. Linn. Soc. London, xxv, 167 ; de Man, 1888, Mém. Soc. Zool. France, i, 47 ; Cobb, 1918, in Ward \& Whipple, Freshwater Biology, 490; Filipjev, 1917, Rev. Zool. Russe, Moscow, ii, 29; 1918, Trav. Lab. Zool., Stat. Biol. Sebastopol, Ser. II, No. 4, 226, 256; 1922, Act. Inst. Agronom. Stauropol., i, 138; Micoletzky, 1922, Arch. f. Naturg., Abt. A, lxxxvii, 383.

The gencra Chromadora and Euchromadora both have the same genotype. Bastian's sclection of vulgaris as type of Chromadora (1905) was actually preceded by de Man's selection of the same species as type of Euchromadora (see Stiles \& Hassall, 1905, U.S. Dept. Agric., Bur. Anim. Indust. Bull. 79, p. 94). The distinguishing characters of the two genera do not appear to be of great importance, and, since it seems probable that Bastian based his genus largely upon the species which he eventually selected as type, we regard Euchromadora as untenable. A considerable number of genera or subgenera proposed for the reception of slight variants of Chromadora are here included in the synonymy of that genus.

\section{Parachromadora Micoletzky, 1914.}

Syn. Triodontolaimus Micoletzky, 1913, nec de Man, 1893.

Cuticle striated, with four submedian rows of bristles. Lateral alae absent. Head not distinct, without lips but with bristles. Lateral organs spiral. Pharynx elongate, thick-walled, prismatic or cup-shaped. Anteriorly it is stiffened by ten to twelve longitudinal rods. Three teeth present, two subdorsal and one ventral. The latter may be contained in a pocket near the base of the pharynx. Oesophagus with a posterior bulb. Caudal end of male with a median ventral row of twelve or thirteen bristle-bearing preanal papillae. The accessory piece appears to be double. Testes paired. Female genital tubes paired, opposed, ontstretched. Caudal glands and spimmeret present.

Hab. Fresh water.

Genotype : P. [Triodontolaimus] alpina (Micoletzky, 1913).

Micoletzky, 1913, Sitz. k. Aliad. Wiss., Wien, cxxii, 117 ; 1914, Zool. Jahrb., Syst., xxxvi, 492.

Micoletzky has proposed the subgenus Parachromadora, of the genus Chromadora, to replace his genus Triodontolaimus, which was preoccupied, as the examination of male specimens led him to believe that a special genus was unjustified. In view of the unusual disposition of the pharyngeal teeth we 
do not consider that the two speeies eoncerned can be inchuded in Chromadora, and have accordingly treated Parachromadora as a separate genus.

\section{Bolbolaimus Cobb, 1920.}

Cuticle striated or unstriated, without bristles. Head not distinet, with (? six) indistinet lips. Lip region elastic and finely subdivided; its margin "serrated by the forward projection of abont fifteen (?) papillae with minute bristles outside the serrations. The appearance is as if each papilla is armed with a pair of minute bristles very difficult to see." Three crowns of short eephalic bristles present. Lateral organs inconspienous, incipient spirals. Pharynx with a wider anterior portion and a narrow, funnel-shaped posterior portion, the former containing a relatively large, protrusible, dorsal tooth and a ventral tooth, which, in the type, is smaller, at its base. (Aceording to the figures, there should be two subventral teetlı). Oesophagus with an anterior pharyngeal bulb, and an elongate posterior bulb with a transverse division in its musenlature. Candal end of male with six ineonspicuous preanal supplementary organs. Spienles stoutish, tapering. Accessory pieces (? two) present. Testis, according to formula, single, anterior, outstretched; "testes" mentioned in the plural in text. Female genital tnbes paired, opposed, ontstretehed. Candal glands and spinneret present.

Hab. Marine (in sand).

Genotype: B. pellucidus Cobb, 1920.

Cobb, 1920, Contr. Sci. Nematol., ix, 319 and key.

39. Cobbia de Man, 1907.

Cuticle striated, with bristles. Head slightly distinet, with six bristles. Lateral organs circular. Buceal capsule cupshaped, armed with three teeth (one dorsal, two subventral). Spicules with a very small spur close to their tips. Accessory piece without posterior process. Female genital tube single, anterior.

Hab. Marine.

Genotype: C. trefusiaeformis de Man, 1907. 232.

de Man, 1907, Tijdschr. Nederl. dierk. Vereen., Leiden, x,

\section{Subfam. 2. DESMOdORINAE nov.}

Pharynx variable in shape, typically containing a single forwardly-directed (dorsal) tooth. Oesophagus with or without posterior bulb.

This subfamily is more or less equivalent to the Desmodorini of Filipjev. 


\section{Desmodora de Man, 1889.}

Syn. Chromadoropsis Filipjev, 1918; Metachromadora Filip. jev, 1918; Amphispira Cobb, 1920; Cinctonema Cobb, 1920; Micromicron Cobb, 1920; Acanthonchus Cobb, 1920; Xenonema Cobb, 1920; Steineria Filipjev, 1922, nec Micoletzky, 1923 ; Prodesmodora Micoletzky, 1923.

Cuticle typically with prominent transverse annulations, except at the extremities, and with fine bristles. Head usually somowhat swollen, smooth, with very small papillae and one or two crowns of small bristles. Lateral organs large, spiral or circular. Pharynx small, consisting of a wider anterior portion with folded walls and containing a dorsal tooth, and a narrower posterior portion passing into the oesophageal lining. Oesophagus with a posterior bulb. Caudal end of male usually with a median series of preanal papillae. Two accessory pieces present. Testis single, outstretched. Body of female swollen in region of genital organs. Female genital tubes paired, opposed, reflexed. Caudal glands and spinneret present.

Hab. Usually marine. One species in soil.

Genotype: D. [Spilophora] communis (Bütschli, I874).

Bütschli, 1874, Abh. Senckenb. Ges., Frankfurt a. M., ix, 282 ; de Man, 1889, Mém. Soc. Zool. France, iii. 9.

Xenonema and Prodesmodora are both described from single female specimens, Micromicron, Cinctonema and Steineria from single males, and Amphispira from an immature specimen of unknown sex. The few characters in which these forms differ from the type of Desmodora appear too slight to warrant their separation from that genus. The same observa. tion applies to Metachromadora and Chromadoropsis.

2. Odontolaimus de Man, 1880.

Syn. Neonchus Cobb, 1893.

Cuticle very finely striated, with scattered bristles. Head without lips or papillae, but with ten bristles. Lateral organs circular. Pharynx a very long, slender tube, decreasing in diameter posteriorly and with somewhat thickened dorsal wall; preceded by a thin-walled "vestibule" containing a triangular dorsal tooth. Oesophagus with a fusiform pharyngeal swelling and a sudden, bulb-like, posterior swelling. Male unknown. Female genital tubes apparently paired. Caudal glands absent.

Hab. Soil.

Genotype: O. chlorurus de Man, 1880.

de Man, 1880, Tijdschr. Ned. dierk. Vereen., Loiden, v, 61 ; 1884, Die frei... lebenden Nematoden d. Niederl. Fauna, SYN. NEM. 
Leiden, 127; Mieoletzky, 1922, Arch. f. Naturg., Abt. A, lxxxvii, 419.

\section{Nudora Cobb, 1920.}

Cuticle with eoarse transverse striations and with ten longitudinal alae, each eontaining a series of $\mathrm{V}$-shaped markings. Head not distinet, with nueh-thickened eutiele. Lips apparently twelve. Six labial bristles and four longer eephalic bristles present. In addition to these, six bristle-like labial papillae. Lateral organs eireular. Pharynx rather small, with eup-shaped anterior portion and narrower posterior portion, and containing a single large, forwardly-directed tooth. Oesophagus with an anterior pharyngeal swelling, separated from the rest by a constriction, and with a eylindroid posterior bulb divided into two parts by a break in its museulature. Tail in both sexes with a few slender submedian preanal and postanal bristles. Caudal end of male with two "obseure" preanal supplementary organs. Spieules very slender. Two stoutish accessory pieces present, somewhat longer than the spienles. Female genital tube single, anterior, outstretehed. Caudal glands and spinneret present.

Hab. Marine.

Cienotype: N. lineata Cobb, 1920.

Cobb, 1920, Contr. Sci. Nematol., ix, 334 and key.

4. Rhinema Cobb, 1920.

Cuticle with coarse transverse striations and with twelve longitudinal alae, each with a series of bifurcate spines presenting a "fishbone-like" appearanee. Head not distinet, with six lips whose apices turn outwards. Six eephalic bristles present. Lateral organs eireular. Pharynx apparently wide anteriorly and narrow posteriorly, eontaining a forwardly-pointing dorsal tooth. Oesophagus with a specialized pharyngeal portion and expanding gradually behind into a bulb-like swelling. Caudal end of male without supplementary organs or papillae, but with a few small bristles at the tip of the tail. Spieules slender. A single, slightly sigmoid, partly protrusible, accessory pieee present. Testes paired, opposed, ontstretehed. Female genital tubes paired, opposed, reflexed. Spinneret present.

Hab. Marine.

Genotype: R. retrorsum Cobb, 1920.

Cobb, 1920, Contr. Sci. Nematol., ix, 335 and key.

5. Oistolaimus Ditlersen, 1922.

Cuticle finely striated, with a few seattered bristles. Head with a single erown of fine bristles. Lateral organs spiral, 
situated far forward. Pharynx with cup-shaped anterior portion and nearly cylindrical posterior portion, the latter occupied by a short spear-like tooth with a barb, like a fishhook. This tooth is apparently protrusible. Oesophagus with large oval postcrior bulb. Male unknown. Female genital tube probably single, posterior. (Description based on a single immature female).

Hab. Marine.

Genotype : O.ferox Ditlevsen, 1922.

Ditlevsen, 1922, Vid. Medd. Naturh. Foren., Copenhagen, Ixxiii, 4.

\section{Digitonchus Cobb, 1920.}

Cuticle rather finely striated, without bristles. Head not distinct, with three, perhaps double, lips, six labial papillae and six rather stout bristles. Lateral organs spiral, situated far forward. Pharynx elongate, with short wide portion anteriorly, and a narrow posterior portion, containing a long, "spear-like" tooth. Male undescribed. Female genital tubes paired, opposed, reflexed. Caudal glands and spimneret present.

Hab. Marine (in sand).

Genotype : D. uniformis Cobb, 1920.

Cobb, 1920, Contr. Sci. Nematol., ix, 314 and key.

7. Anticyclus Cobb, 1920.

Cuticle unstriated, without bristles. Head not distinct, with six indistinct lips and two or three crowns of bristles. Lateral organs large, circular. Pharynx relatively short and wide, with a single conical tooth at its base. Oesophagus gradually swollen behind, without bulb. Caudal end of male with seventeen equidistant preanal supplementary organs. Two accessory pieces present. Testes paired, opposed, outstretched, the posterior considerably the shorter. Female genital tube single, anterior, outstretched. Caudal glands and spinneret present.

Hab. Hot salt springs.

Genotype : A. exilis Cobb, 1920.

Cobb, 1920, Contr. Sci. Nematol., ix, 331 and key; Micoletzky, 1922, Arch.f. Naturg., Abt. A, Ixxxvii, 128.

Micoletzky apparently regards Anticyclus as a subgenus of Linhomoens.

\section{Cophonchus Cobb, 1920.}

Cuticle with very fine transverse and also longitudinal striations. A few short bristles in the cervical region. Head rather narrowed, with thickened cuticle. Lips apparently 
three. Six (?) labial papillae and a erown of eephalie bristles present. Lateral organs cireular. Pharynx short and wide, eontaining a relatively large, forwardly-projecting tooth. Oesophagus swollen gradually behind, without bulb. A pair of ocelli present. Caudal end of male with a single large supplementary organ, and apparently some eaudal papillae. Spicules slender. Accessory pieces present both in front of and behind the spienles. 'Testes paired, opposed, outstretehed. Female undeseribed. Candal glands and spimmeret present.

Hab. Marine.

Genotype: C. ocellatus Cobb, 1920.

Cobb, 1920, Contr. Sci. Nematol., ix, 328 and key.

9. Anoncholaimus Cobb, 1920.

Cutiele finely striated, very thin. A few bristles on the tail. Head not distinet, with thin, flattened lips. Labial papillae and a erown of cephalie bristles present. Lateral organs small, transversely elliptieal, opening anteriorly. Pharynx nearly as wide as long, straight-sided anteriorly, somewhat narrower behind. At its anterior end there is a vestigial dorsal tooth. Oesophagus somewhat expanded at each end, without bulb. Male undeseribed. Female genital tubes paired, opposed, reflexed, the posterior ovary a little smaller than the anterior. Caudal glands (preanal) and spinneret present.

Hab. Marine.

Genotype: A. mobilis Cobb, 1920.

Cobb, 1920, Contr. Sci. Nematol., ix, 312 and key.

10. Asymmetrella Cobb, 1920.

Cuticle unstriated. Head slightly distinct, with three unequal lips and a erown of ten bristles. Lateral organs apparently large, transversely elliptical, open behind. Pharynx eylindrieal, spacions, considerably longer than wide, with a dorsal tooth at its entrance, bent inwards at right angles. Oesophagus cylindroid, without bulb. Three ocelli (?) present. Male unknown. Female genital tubes "probably double and symmetrically placed." (Deseription apparently based on a single immature female).

Hab. Sea-water.

Genotype: A. glabra Cobb, 1920.

Cobb, 1920, Contr. Sci. Nematol., ix, 287 and key.

11. Isonemella Cobb, 1920.

Cuticle unstriated, with bristles only at the extremities. Head narrowed, without recognizable lips. Ten eephalic 
bristles present. Lateral organs circular. Pharynx funnelshaped, preceded by a small "vestibule," and containing a minute, forwardly-directed tooth ("ventral (?) " in description, dorsal in figure). Oesophagus gradually swollen behind, without bulb. A pair of ocelli present. Genital organs not described. Caudal glands and spinneret present. (Description based on a single immature male specimen).

Hab. Marine.

Genotype : I. acuta Cobb, 1920.

Cobb, 1920, Contr. Sci. Nematol., ix, 329 and key.

12. Synonema Cobb, 1920.

Cuticle unstriated, without bristles. Head not distinct, with four submedian bristles. Lip-region apparently with twelve ribs (? folds). Lateral organs small, incipient spirals. Pharynx narrow, somewhat funnel-shaped, containing a single dorsal tooth. Oesophagus with pyriform posterior bulb-like swelling. Male unknown. Female genital tube single, anterior, outstretched. Caudal glands and spinneret present. (Description based on a single immature female specimen).

Hab. Marine.

Genotype : S. braziliense Cobb, 1920.

Cobb, 1920, Contr. Sci. Nematol., ix, 330 and key.

13. Mesodorus Cobb, 1920.

Cuticle very finely striated, without bristles except at anterior end. Head not distinct, rounded, with twelve labial papillae and three crowns of bristles. Lateral organs spiral. Pharynx fumnel-shaped, narrow, containing a single forwardlydirected tooth near its anterior end. Oesophagus with a "rather obscurely pyriform" posterior bulb. Caudal end of male with twenty-five preanal supplementary organs. Spicules slender. Two accessory pieces present. Testis single, anterior, straight. Female unknown.

Hab. Marine.

Genotype: M. cylindricollis Cobb, 1920.

Cobb, 1920, Contr. Sci. Nematol., ix, 325 and key.

14. Iotadorus Cobb, 1920.

Cuticle coarsely striated, without bristles. Head not distinct, truncate, with twelve papilla-like lips. Cephalic bristles "probably" present. Lateral organs transversely elliptical, situated far forward. Pharymx apparently very narrow, completely filled by a forwardly-directed tooth. Oesophagus with pyriform posterior bulb. Caudal end of 
male with a few minute bristles. Spieules with bifureate tips, the anterior fork rudimentary, the posterior somewhat sigmoid and aente. An aceessory piece present, with posterior process. Testis single, anterior, outstretehed. Female unknown. Spinneret present.

Hab. Marine.

Genotype: I. punctulatus Cobb, 1920.

Cobb, 1920, Contr. Sci. Nematol., ix, 336 and key.

15. Ypsilon Cobb, 1920.

Cuticle coarsely striated, with a few bristles in the cervical and eandal regions. Head with four bristles and three minute, indistinet lips, surrounded by three pairs of labial papillae. Pharynx narrow and funnel-shaped, containing a large dorsal tooth, the anterior portion of which is eupshaped and fixed obliquely on to the main shaft. Oesophagus with cylindroid posterior swelling. Candal end of male with three ininute preanal supplementary organs. Spieules rather slender, appearing as if barbed near their roots. A single slender accessory piece present, with indistinet posterior proeess. Female undeseribed. Caudal glands and spinneret present.

Hab. Marine.

Genotype: $Y$. exile Cobb, 1920.

Cobb, 1920, Contr. Sci. Nematol., ix, 314 and key.

16. Monoposthia de Man, 1889.

Cuticle striated, with bristles. Head with papillae and bristles. Lateral organs small, eireular. Pharynx similar to that of Spilophora, containing a dorsal tooth. Oesophagus with a posterior bulb. Candal end of male without preanal or postanal papillae. A single symmetrieal spieule present, and no aceessory piece, aceording to de Man.* Testes paired. Female genital tube single, anterior, ontstretched.

Hab. Marine.

Genotype: M. [Spiliphera] costata (Bastian, 1865).

Bastian, 1865, Trans. Linn. Soc. London, xxv, 166; de Man, 1889, Mém. Soc. Zool. France, ii, 9.

17. Thoracostoma Marion, 1870.

Syn. Hemipsilus de Quatrefages, 1846; Deontostoma Filipjev, 1916, Jägerskiöldia Filipjev, 1916; Leptosomatides Filipjev, 1918.

* According to Steiner, a large accessory piece is present in the genotype. The presence of a single spicule, as deseribed by do Man, prevents the inclusion of this genus in Spilophora, with which it seems to be otherwise in agreemont. 
Cuticle finely striated, without bristles except in the cervical region. Head not distinct, but narrowed, with two crowns of bristles and covered by a specialized cuticular cap. Pharynx short, three-sided, containing a dorsal tooth which may be simple or bilobed. Oesophagus without bulb, but with ocelli, which may be furnished with lenses. Candal end of male with several pairs of ventral preanal and postanal bristles. There may be a single median preanal supplementary organ and two rows of submedian supplementary organs. A bipartite accessory piece present. Testes opposed, outstretched. Femalc genital tubes paired, opposed, reflexed. Caudal glands and spinneret present.

Hab. Marine.

Genotype : probably T. cchinodon Marion, 1870, according to Stiles \& Hassall (1905).

Marion, 1870, Ann. Sci. Nat., Paris, Zool., xiii, 25; Cobb, 1914, Contr. Sci. Nematol., i, 31; de Man, 1904, Res. Voy. S.Y. Belgica (Zool.), 25.

The genus Hemipsilus was considered by Bütschli (1874, Abh. Senckenb. Ges., Frankfurt a. M., ix, 277) to be a synonym of Thoracostoma. The original diagnosis (de Quatrefages, 1864, Ann. Sci. Nat., Paris, Zool., (3) vi, 131) and the description of his unnamed species are so incomplete that we have decided to follow Buitschli, although it is doubtful whether the genus could ever be recognized. The genus Jägerskiöldia Filipjev, 1916, appears to have been proposed for certain "sharp-tailed" species of Thoracostoma, including T. acuticaudatum Jägerskiöld, 1901, which is probably intended as its type. Deontostoma Filipjev was proposed for Thoracostoma arcticum Savelev. The description of this species (Savelev, 1912, Trav. Soc. Nat., Petrograd, xliii, 124) does not, in our view, indicate any characters of sufficient importance to justify the erection of a separate genus for it. Leptosomatides, according to Filipjev (1918, Trav. Lab. Zool., Stat. Biol. Sebastopol, Ser. II, No. 4, 50), is intermediate between Leptosomatum and Deontostoma. Leptosomatum, in our view, belongs to the family Alaimidae, and has no close relationship to Thoracostoma. Leptosomatides, however, appears to differ from typical species of Thoracostoma almost solely in the less well-developed condition of its cephalic cuticular cap. We have therefore included it in the synonymy of this genus.

\section{Thoracostomopsis Ditlevsen, 1919.}

According to Ditlevsen, this genus differs from Thoracostoma in having the head much narrower than the rest of the body, and also in the presence within the plarynx of a thin, acute "spear" which may protrude from the month-opening. 
The cephalic bristles are highly developed, those in the posterior erown being extremely long and tentacle-like.

Hab. Marine.

Genotype: T. barbata Ditlevsen, 1919.

Ditlersen, 1919, Tid. Medd. Naturh. Foren., Copenhagen, $\mathrm{Ixx}, 181$.

19. Discophora Villot, 1875, nec Boisduval, 1836.

This genus is very vaguely defined by Villot. The following charaeters are taken from Eberth's deseription and figures of the genotype :-

Cuticle smooth, with short lateral rows of bristles in the neek region. Head not distinct. Mouth with three small papillae. Head strengthened internally by a pair of lateral plates, each having two perforations. Oesophagus simple, elub-shaped. Ocelli present. Male with a pair of rather stout siekle-shaped spieules and a small aceessory piece with a posterior process. Female genital tubes paired, opposed. Spinneret present.

Hab. Marine.

Genotype: D. [Enoplus] cirrhatus (Eberth, 1863).

Eberth, 1863, Untersuchungen über Nematoden, Leipzig, 34; Villot, 1875, Arch. Zool. exp. et gén., iv, 463.

The armature of the head seems to suggest that this genus may be related to Thoracostoma. Eberth deseribes the lateral plates as belonging to the "pharynx," but this organ is not otherwise deseribed. The validity of the genus being somewhat doubtful, we do not suggest a new name for it.

\section{Onyx Cobb, 1891.}

Cutiele finely striated. Head rounded, with retractile lips (? twelve) and pointed papillae. Lateral organs large, spiral. Pharynx contains a spear-like tooth attached to its dorsal wall, and a threefold growth from the walls of the anterior part of the pharynx acts as guide for this tooth. Oesophagus with narrow anterior half and stouter, nearly cylindrical, posterior half. Caudal end of male with a single, bristlebearing, ventral postanal papilla, and a number of ventral preanal supplementary organs. 'Two accessory picees present. Testes paired, opposed, sometimes reflexed at ends. Female genital tubes paired, opposed, reflexed. Caudal glands present.

Hab. Marine (in sand).

Genotype: O. perfectus Cobb, 1891.

Cobb, 1891, Proc. Limn. Soc. N.S.W., Sydney, vi, 146. 
21. Pharetrolaimus de Man, 1921.

Cuticle smooth. Head hemispherical, slightly distinct, with two crowns each of six papillae, but without bristles. Lateral organs small, pit-likc. Buecal eavity tubular, narrow and thin-walled, containing a spear-like tooth, which is arrow-shaped in ventral view, with three posterior processes. There are also apparently thrce very small denticles near the anterior cnd. Structure of oesophagus uncertain. Male unknown. Vulva in oesophageal region. Female genital tube single, posterior, reflexed. Caudal glands absent. (Description based on a single immature female).

Hab. Soil.

Genotype : $P$. sagittifer de Man, 1921.

de Man, 1921, Capit. Zool., i, 42.

22. Catalaimus Cobb, 1920.

Cuticle very finely striated, without bristles. Head not distinct, rounded, with six labial papillae and a crown of ten short bristles. Lateral organs apparently horseshoe-shaped, open behind. Pharynx with somewhat funnel-shaped anterior portion, containing a long and slender, forwardly-directed tooth, and an extremely long, slender, tubular posterior portion, extending backwards behind the nerve-ring. Oesophagus eylindroid, without bulb. A pair of ocelli present. Male unknown. "Ovaries probably double and reflexed." Spinneret present. (Description based on a single immature female).

Hab. Marine.

Genotype : C. acuminatus Cobb, 1920.

Cobb, 1920, Contr. Sci. Nematol., ix, 308 and key.

23. Laxus Cobb, 1894.

Cuticle rather coarsely striated, with bristles throughout. Head not distinct, with bristles. Latcral organs spiral. In the genotype the oral cavity has transverse ehitinoid ridges. Pharynx narrow, "probably containing an obscure dorsal tooth" [in L. septentrionalis]. Oesophagus with anterior swelling and spherieal posterior bulb. Caudal end of male with several pairs of submedian preanal and postanal bristles. One or two accessory pieces present. Testis single, or paired, opposed. Female genital tubes paired, opposed, reflexed or outstretched. Caudal glands present.

Hab. Marine (in sand).

Genotype : L. longus Cobb, 1894.

Cobb, 1894, Proc. Linn. Soc. N.S.W., Sydney, (2) viii, 413 ; 1914, Contr. Sci. Nematol., i, 29. 
The status of this genus appears very unsatisfactory. It was originally based on a single male speeimen of the genotype and the female of a seeond speeies, contortus. To these the third speeies, septentrionalis, was added in 1914, and this differs in several respeets from the others (single aceessory piece, paired testes, ovaries outstretehed instead of reflexed, ete.). In the figure of the genotype no pharyngeal eavity is shown, and the presence of a pharyngeal tooth secms, in any ease, to be rather uncertain.

24. Xanthodora Cobb, 1920.

Cuticle coarsely striated, except on the head. Head not distinet, with three lips and a erown of twenty-six short, stont bristles, arranged in groups. Lateral organs ineipient spirals. Pharynx apparently narrow and elongate, eontaining a single dorsal, anteriorly-direeted tooth. Oesophagus with a constriction immediately behind the pharynx, and gradually swollen behind, where it is divided by breaks in the musculature into three regions of unequal length, the anterior the longest. Caudal end of male with six preanal supplementary organs, and additional nerve-endings between them. Spicules tapering towards each end. Aecessory piees inconspicuous exeept for their distal portion. Testis probably single, anterior, outstretched. Female genital tubes paired, opposed, reflexed. Ova "ocenr in the uteri one at a time." Candal glands and spinneret present.

Hab. Marine.

Genotype: X. nuda Cobb, 1920.

Cobb, 1920, Contr. Sci. Nematol., ix, 317 and key.

25. Choniolaimus Ditlevsen, 1919.

Cuticle striated, apparently without bristles exeept for a single ring in the constrietion behind the head. Head truncate, separated by a shallow groove. Lateral organs large, spiral. Pharynx funnel-shaped, without teeth. Oesophagus with a distinct posterior bulb. Caudal end of male with thirteen ventral preanal supplementary organs. "Accessory piece (or pieces?) embracing the tips" of the spieules like a sheath. Female unknown. (Gemus based on a single male specimen).

Hab. Marine.

Genotype: C. papillatus Ditlevsen, 1919.

Ditlevsen, 1919, Vid. Medd. Naturh. Foren., Copenhagen, $1 \mathrm{xx}, 185$.

Ditlevsen expresses the view that possibly this form will prove to be related to Chromadora. 
26. Dorylaimopsis Ditlevsen, 1919.

Cuticle striated, and marked with transverse and longitudinal rows of dots. Head not distinct, with smooth cuticle and a crown of short and stout bristles. Lateral organs large, spiral. Pharynx apparently tubular, its walls presenting the appearance of a protrusible "spear," but of quite different structure from that of the Anguillulinidae. Oesophagus swollen posteriorly, without bulb. Caudal end of male with a median ventral row of preanal papillae and two subventral rows of postanal bristles. Spicules rather long, bent almost at right angles before the tip, and with a hook-shaped prominence ventrally somewhat behind the middle. Two accessory pieces present, the posterior with a posterior process. Female genital tubes paired, opposed, outstretched.

Hab. Marine.

Genotype: D. punctatus Ditlersen, 1919.

Ditlevsen, 1919, Vid. Medd. Naturh. Foren., Copenhagen, $\operatorname{lxx}, 162$.

Subfam. 3. IRONINAE Micoletzky, 1922.

Pharynx typically elongate, tubular, with three, or a multiple of three, teeth (sometimes eversible) near its anterior end. Oesophagus club-shaped, usually without distinet bulb.

1. Ironus Bastian, 1865.

Syn. Thalassironus de Man, 1889; Cephalonema Cobb, 1893, nec Pierantoni, 1916; Nanonema Cobb, in Stiles \& Hassall, 1905.

Cuticle unstriated, without bristles or lateral alae. Head with three lips and four submedian bristles. Lateral organs variable. Pharynx long and narrow, with three strong hookshaped teeth at its anterior end, and three smaller denticles a little further back. The lips are movable, allowing protrusion of the teeth in the pharynx. Oesophagus gradually swollen behind. Caudal end of male without papillae or with a few ventral preanal bristles. Female genital tubes usually paired, opposed. Some species are hermaphrodite (Cobb). Caudal glands present. Spinneret absent.

Hab. Fresh water and soil.

Genotype : I. ignavus Bastian, 1865.

Bastian, 1865, Trans. Linn. Soc. London, xxv, 103; Cobb, 1893, Agric. Gaz. N.S.W., Sydney, iv, 825; Cobb, in Stiles \& Hassall, 1905, U.S. Dept. Agric., Bur. Anim. Indust. Bull. 79, 122 ; Micoletzky, 1922, Arch.f. Naturg., Abt. A, lxxxvii, 323.

de Man appears to have been influenced ehiefly by the marine habitat of the species britannicus in creating a new 
genns Thalassironus for this form. As regards its morphology, he does not mention any satisfactory distinguishing characters.

2. Odontophora Bütschli, 1874.

Cuticle apparently unstriated, with scattered bristles. Hearl trincate, not distinct, with bristles. Month surronnded by three triangular tooth-like structures, capable of inversion. Pharynx fumel-shaped, unarmed except for the tooth-like structures mentioned. Oesophagns with a rather pronounced bulb-like posterior swelling. Female genital organs paired, opposed. Male undescribed.

Hab. Marine.

Genotype: O. marina Bütschli, 1874.

Bütschli, 1874, Abh. Senckenb. Ges., Frankfurt a. M. ix, 3, 285.

This genus is very imperfectly known, and, apart from the presence of bristles on the body, there appears to be little to distinguish it from Ironus.

3. Mesonchium Cobb, 1920.

Syn. Pepsonema Cobb, 1920.

Cuticle rather finely striated, with some bristles towards the extremities. Head slightly cxpanded, with indistinct lips. Two crowns each of six labial papillae present, and a single crown of four cephalic bristles. Lateral organs spiral. Pharynx rather narrow, apparently three-sided, containing anteriorly three forwardly-pointing tceth. Oesophagns slightly swollen behind, but without bulb. Caudal end of male with a series of very indistinct nerve-endings. Spicules slender. An accessory piece (? two accessory pieces) with slender posterior process present. Testes paired, opposed, outstretched. Female genital tubes paired, opposed, reflexed at their ends. Caudal glands and spinneret present.

Hab. Marine.

Genotype : M. poriferum Cobb, 1920.

Cobb, 1920, Contr. Sci. Nematol., ix, 294 and key.

Pepsonema is regarded tentatively as a syuonym of Mesonchium, the descriptions of the genotypes being almost identical. The presence of "one or two minute, onchiumlike processes" at the base of the pharynx is mentioned in Pepsonema, but these are not shown in the figure. The spicules are said to be "obscurely retrorsely barbed" in Pepsonema, and this character is not mentioned in Mesonchium. The accessory piece is spoken of in the singular in Mesonchium, and accessory pieces, in the plural, in Pepsonema. 


\section{Ironella Cobb, 1920.}

Cutiele unstriated and without bristles. Slight lateral alae present. Head not distinct, with six small lips and twelve short bristles. Lateral organs apparently eonsisting of a transverse groove. Pharynx long, tubular. At its anterior end there are three bicuspid teeth projecting into the mouthopening, and behind these numerous minute denticles. Oesophagus without posterior bulb. Caudal end of male with a single preanal supplementary organ and a large, curved bristle. Testes paired, parallel, outstretched. Female genital tubes opposed, reflexed. Caudal glands and spinneret present.

\section{Hab. Marine.}

Genotype : I. prismatolaima Cobb, 1920.

Cobb, 1920, Contr. Sci. Nematol., ix, 277 and key.

There appears to be nothing to separate this genus from Ironus except the presence of numerous denticles in place of the three posterior dentieles of Ironus.

\section{Apodontium Cobb, 1920.}

Cuticle finely striated, with a few bristles towards the extremities. Head not distinct, with four stout bristles. Lateral organs transversely elliptical, open behind. Pharynx narrow, funnel-shaped, with six eversible teeth at its anterior end. Oesophagus cylindroid, without bulb. Caudal end of male without supplementary organs, special bristles or papillae. Spicules slender. Two accessory pieces present, simple and rather stout. Testis single, anterior, ontstretched. Caudal glands and spinneret present. Female undescribed.

Hab. Marine.

Genotype : A. pacificum Cobb, 1920.

Cobb, 1920, Contr. Sci. Nematol., ix, 277 and key.

\section{Trissonchulus Cobb, 1920.}

Cuticle unstriated and without bristles. Head distinctly marked off by a constriction, with six swollen lips, each bearing two papillae, one behind the other. Inner surface of each lip beset with numerous minute denticles. Lateral organs poeket-like, with transversely elliptical anterior opening. Pharynx small, eontaining three forwardly-pointing, apparently eversible teeth. Oesophagus with a slight posterior bulb-like swelling. Candal end of male with a slight preanal ventral elevation (possibly a supplementary organ), and three pairs of preanal and four pairs of postanal subventral papillae. A slender accessory piece present. Testes paired, opposed, the anterior longer and reflexed, the 
posterior shorter and outstretehed. In comnection with the male genital organs there are scveral glands opening into the ejaculatory duct behind. Female genital tubes paired, the anterior without ovary, the posterior reflexed. Caudal glands and spinneret present, the latter ventral.

Hab. Marine.

Genotype: 'T'. oceanus Cobb, 1920.

Cobb, 1920, Contr. Sci. Nematol., ix, 297 and key.

7. Synodontium Cobb, 1920.

Cutiele rather finely striated, with bristles towards the extremities. Head not distinet, apparently with six lips, each bearing a papilla. Six long and stont cephalic bristles present. Lateral organs very indistinct. Pharynx fumnelshaped, fairly large, with a ring of twelve (?) small teeth at its anterior end. Oesophagus "ends posteriorly in a faint, elongated, pyriform, valveless bulb." Caudal end of male with fifty to seventy preanal supplementary organs. Spienles slender. Two accessory pieees present, with blunt posterior processes. Testes paired, opposed, ontstretehed. Female genital tube single, posterior, outstretehed. Candal glands and spinneret present, the latter terminating in a hemispherical bntton with three eversible seetors.

Hab. Marine.

Genotype: S. fecundum Cobb, 1920.

Cobb, 1920, Contr. Sci. Nematol., ix, 280 and key.

\section{Trigonolaimus Ditlevsen, 1919.}

Cutiele unstriated and without bristles. Head rounded, with two erowns of bristles. Lateral organs hoop-shaped. Pharynx long, prismoid, with the apex direeted backwards. Anteriorly it contains a bundle of six stont, slightly eurved, apparently movable, ehitinoid rods with their tips projecting forwards (? three bieuspid teeth), and near the bases of these a number of small prismatic bodies. Oesophagns somewhat swollen posteriorly. An aceessory piece, with a posterior proeess, present. Female genital tubes paired, opposed.

Hab. Marine.

Genotype : T. armatus Ditlevsen, 1919 (by page precedence).

Ditlevsen, 1919, Vid. Medd. Naturh. Foren., Copenhagen, lxx, 177.

9. Diodontolaimus Southern, 1914.

Cuticle eoarsely striated. Hear not distinet, with eonical labial papillae and a single erown of four submedian bristles. Lateral organs ineipicut spirals. A eylindrical buceal eapsule present, with thick walls, and armed with two subventral 
teeth at its anterior end. Dorsal tooth absent. Oesophagus gradually swollen behind, without bulb. Caudal end of male with nine median preanal supplementary organs. Aecessory piece with a posterior proeess. Testis single. Female unknown.

Hab. Marine (in sand).

Genotype: D. sabulosus Sonthern, 1914.

Southern, 1914, Proc. R. Irish Acad., xxxi, 31.

\section{Gonionehus Cobb, 1920.}

Cutiele very coarsely striated, with submedian bristles throughout. Head not distinet, with six lips having " hinged" terminal prolongations. Ten cephalic bristles present. Lateral organs large, spiral. Pharynx wide, funnel-shaped, containing two submedian blade-like teeth anteriorly. Oesophagus somewhat swollen behind, without bulb. Caudal end of male without supplementary organs, caudal papillae or special bristles, but with bristles similar to those on the body. Spieules slender, their shafts straight near the root, curved distally. 'Two ineonspieuous aecessory piees present. Testes paired, opposed, ontstretehed. In conneetion with the male genital organs there are three pairs of preanal aeessory glands, with duets leading to the cloaea. Female genital tubes paired, opposed, outstretehed, the posterior without ovary.

Hab. Marine (in mud).

Genotype : G. villosus Cobb, 1920.

Cobb, 1920, Contr. Sci. Nematol., ix, 315 and key.

11. Dolicholaimus de Man, 1888.

Cutiele unstriated and withont bristles or lateral alae. Head with feebly-developed lips and without, or with very short, bristles. Lateral organs in the form of grooves. Pharynx elongate, divided by a constrietion into a short anterior and a much longer, probably six-sided, posterior portion. At the base of the anterior portion there are three, probably movable, teeth which projeet into the mouth-opening. Oesophagus without posterior bulb. Caudal end of male with preanal and postanal papillae. An aceessory piece present. Female genital tubes paired, reflexed. Caudal glands present.

Hab. Marine.

Genotype : D. marioni de Man, 1888.

de Man, 1888, Mém. Soc. Zool. France, i, 31.

12. Syringolaimus de Man, 1888.

Cutiele unstriated and withont bristles. Head with feebly-leveloped lips and withont bristles. Lateral organs 
short, narrow grooves. Pharynx an elongate, probably three-sided tube, narrowing a little behind, and furmished anteriorly with three small teeth. Oesophagus with a posterior bulb. Two oeelli present at the anterior end of the oesophagus. Caudal end of male without papillae. An accessory piece present. Female genital tubes paired. Caudal glands present.

Hab. Marine (littoral).

Genotype : S. striatocaudatus de Man, 1885.

de Man, 1sss, Mém. Soc. Zool. France, i, 34.

13. Actinonema Cobb, 1920.

Cuticle thick, eoarsely striated, withont bristles. " Head set off by contraction and a deep constrietion, subtruneate; month more or less depressed. The lip-region is one-half as high as wide, and appears to be composed of three fairly welldeveloped, rounded, subdistinet lips, which are set off by eonstrietion. This lip-region appears as if protruding from within the thick cuticle. . . On the lips there are no obvious signs of a enticle. The pharynx is very small and inconspieuous, or even absent apparently." Apparently a minute dorsal tooth (situated, aceording to the figure, on one of the "lips"). Lateral organs greatly elongate transverse slits. Oesophagus swollen behind, without bulb. Caudal end of male without supplementary organs or papillae. Spieules rather stout, tapering. A single, slender, aecessory piece present. Testis single, anterior, outstretehed. Female genital tubes paired, opposed, reflexed. Caudal glands and spimneret present.

Hab. Marine.

Genotype: A. pachydermatum Cobb, 1920.

Cobb, 1920, Contr. Sci. Nematol., ix, 335 and key.

\section{Subfam. 4. ENOPLINAE Micoletzky, 1922.}

Chitinoid wall of pharynx typically reduced to three stout jaws, bearing simple or complex teeth anteriorly and connected with the lips, which are eversible. Oesophagus more or less chub-shaped, usually without distinet bulb.

1. Enoplus Dujardin, 1845.

Syn. Tricontus Dujardin, 1845; Lineola Kölliker, 1845, nec Baer, 1827; Enoplolaimus de Man, 1893; Demonema Cobb, 1894 ; Enoploides Saveler, 1912.

Cuticle with transverse striations and without bristles except near the extremities. Head usually with three lips 
and a varying number of bristles. The lips may, in some species, be considerably reduced. Lateral organs oval, inconspicuous. Cavity of pharynx much reduced, funnelshaped, containing three jaws, each of which consists of a more or less complex chitinoid structure, connected with one of the lips, and provided with a simple or complex tooth anteriorly. Oesophagus not distinctly muscular, without posterior bulb, and frequently much pigmented, the pigment sometimes forming ocelli. Caudal end of male with preanal and postanal bristles, and with a single supplementary organ. A pair of accessory pieces present. Female genital tubes paired, opposed. Caudal glands and spinneret present.

Hab. Marine.

Genotype: Probably E. tridentatus Dujardin, 1845, according to Stiles \& Hassall (1905).

Dujardin, 1845, Histoire naturelle des Helminthes, Paris, 233 ; Bastian, 1865, Trans. Linn. Soc. London, xxv, 147; Southern, 1914, Proc. R. Irish Acad., xxxi, 48.

Enoplolaimus and Enoploides are treated by Micoletzky (1922) as subgenera of Enoplus. There is considerable variation in the form of the jaws in Enoplus (sens. lat.), and we do not feel that the species can at present be grouped conveniently in subgenera based on the structure of these organs. For similar reasons we have included Demonema in the synonymy.

\section{Synonchium Cobb, 1920.}

Cuticle rather coarsely striated, with transverse rows of large circular elements, and on each side two irregular sublateral rows of pores. Head truncate, the mouth surrounded by a ring of twelve slight swellings (? Iips), and behind these two crowns of six papillae each. Lateral organs spiral. Pharynx rather narrow when closed, containing three large, elongate, protrusible, jaws, each with three incurved teeth at its apex and two smaller teeth at its sides. Oesophagus with an anterior swelling but without posterior bulb. Caudal end of male apparently with two small preanal supplementary organs. Spicules stont, straight to near the tips, where they are bent rentrally at an obtuse angle. Apparently no accessory piece. Female genital tubes probably paired, opposed, reflexed. Spinneret present.

Hab. Marine.

Genotype: S. obtusum Cobb, 1920.

Cobb, 1920, Contr. Sci. Nematol., ix, 290 and key.

3. Triodontolaimus de Man, 1893, nec Micoletzky, 1913.

Cuticle unstriated and without bristles. Head rather distinct, with three inconspicnous lips and a crown of ten short, thick

SYN. NEM. 
bristles. Lateral organs oval. Pharynx much reduced, containing anteriorly three large, single-pointed teeth carried on chitinoid jaws. Oesophagus without bulb, unpigmented. Caudal end of male with a few postanal papillae, but without prcanal papillae or supplementary organs. An accessory piece present. Testes paircd. Female genital tubes paired, opposed, reflexed. Caudal glands and spinneret present.

Hab. Marine.

Genotype: T. [Enoplus] acutus (Villot, 1875).

Villot, 1875, Arch. Zool. exp. et gén., iv, 460; de Man, 1893, Mém. Soc. Zool. France, vi, 114.

\section{Xyala Cobb, 1920.}

Cuticle with numerous longitudinal alae, subdivided by coarse transverse striations. A few bristles, in groups of four, present in the cervical region, and a few subdorsal caudal bristles. Head with two crowns of bristles. Lateral organs circular. Lips form three simple, incurved, protrusible jaws. Pharynx divided transversely into two portions by an internal cuticular ridge. Oesophagus with pyriform pharyngeal swclling, but without posterior bulb. Candal end of male without supplementary organs or papillae. Spicules slender. 'Two slender accessory pieces present, their proximal ends enveloping the spicules. Testes paired, opposed, ontstretched. Ovary single, anterior, outstretched. Candal glands and spinneret present.

Hab. Marine.

Genotype: X. striata Cobb, 1920.

Cobb, 1920, Contr. Sci. Nematol., ix, 289 and key.

5. Selachinema Cobb, 1915.

Cuticle fincly striated. Head with two crowns of bristles. Lateral organs spiral. Pharynx "triangularly concavepyramidal," with three jaws; two submedian, well developed, one median, rudimentary. The jaws consist of two parts, cach bearing two rows of denticles. Oesophagus without posterior bulb. Genital organs undescribed. (Deseription based on a single immature specimen).

Hab. Marine.

Genotype: S. ferox Cobb, 1915.

Cobb, 1915, Contr. Sci. Nematol., iv, 113.

6. Fiaera Southern, 1914.

Cuticle smooth or faintly striated. Head distinct, with a single crown of ten stout bristles. Lateral organs cup-shaped. Pharynx small, containing three jaws. The two submedian 
jaws bear each a large tooth, the dorsal jaw two small teeth. Oesophagus without bulb. Caudal end of male with a large median preanal papilla and a double row of subventral bristles. A shcath-like accessory piece present. Female genital tubes paired, opposed, reflexed. Caudal glands present.

Hab. Marine.

Genotype: $F$. longisetosa Southern, 1914.

Southern, 1914, Proc. R. Irish Acad., xxxi, 34.

7. Dignathonema Filipjev, 1918.

Cuticle striated. Head not distinct, with submedian bristles. Lateral organs large, spiral. Pharyngeal walls apparently represented by three rod-like jaws, contained within a much swollen anterior part of the ocsophagus, and bearing anteriorly each three teeth, of which the two outer are bifid, the middle tooth simple. The dorsal jaw and its tceth are apparently much less well developed than the others, and the jaw itself not well chitinized. Oesophagus much swollen behind. Female genital tubes short, reflexed. Male unknown.

Hab. Marine.

Genotype: D. bulbosa Filipjev, 1918.

Filipjev, 1918, Trav. Lab. Zool., Stat. Biol. Sebastopol, Ser. II, No. 4, 205.

Filipjev, in his generic diagnosis, states that there are two large lateral lips and two large papillae. His figures indicate the presence of three lips, and our diagnosis, as regards the head, is chiefly based upon the figures. The genus is considered by Filipjev to resemble closely Cyatholaimus and Halichoanolaimus, although highly specialised for carnivorous habits. We consider it much more nearly related to Enoplus, Triodontolaimus, Selachinema and Fiacra, with one of which it may possibly prove to be synonymous.

\section{Rhabdotoderma Marion, 1870.}

Cuticle with characteristic transverse ring-shaped thickenings, and with scattered bristles. Head not distinct, truncate, with a crown of bristles. Pharynx elongate, apparently containing (three ?) broad teeth at its anterior end. Behind these there is a complex apparatus consisting of two jaw-like structures, with serrate internal surfaces, in connection with two stouter chitinoid rods, dirceted postcriorly and converging towards their posterior ends. Each of these rods carries three tecth at intervals along its inner surface. Ocsophagus slightly swollen behind, without bulb. A pair of ocelli 
present, with lenses. Nale with two complex accessory pieces (?). Female genital tubes paired, opposed, reflexed. Caudal glands and spinnerct present.

Hab. Marine.

Genotype : $R$. morstatti Marion, 1870.

Marion, 1870, Ann. Sci. Nat., Paris, Zool., (5) xiii, Art. 14, 31.

It is difficult to draw up an intelligible diagnosis of this genus from the description given by Marion, which is somewhat obscure and occasionally self-contradictory. Although the structures comnected with the pharynx are stated to be paired, it seems very probable that they are in reality triradially arranged. In his brief generic diagnosis Marion states that there are two longitudinal accessory pieces in front of the spicules, and two other median pieces. In the specific description of the type, however, he mentions two lateral, bifid, accessory pieces and one median piece. The figure suggests two accessory pieces, each with three sharp, forwardlydirected processes.

\section{Cheironchus Cobb, 1917.}

The only available diagnosis of this genus is contained in the legend to a figure and in the "formula" of the genotype. The genotype is said to be "A nema whose bilaterally symmetrical mandibles have arisen from the ventrally submedian sectors of the head at the same time that the dorsal elements of the pharynx have disappeared. Cheironchus has the general appearance of Selachinema, but has no vestigial dorsal jaw, and presents both pharyngeal and cardiac bulbs." According to the formula, the testes are paired, opposed, outstretched; the female genital tubes paired, opposed and reflexed. Spinneret present.

Hab. Not mentioned.

Genotype: C. vorax Cobb, 1917.

Cobb, 1917, Contr. Sci. Nematol., v, 119.

\section{Appendix to Oncifolamindae.}

The following forms are of uncertain position.

a. Heterocephalus Marion, 1870, nec Rüppel, 1842.

Head suddenly narrowed, distinct, truncate, surrounded by a crown of stout, recurved bristles. Buccal cavity rather large, armed with chevron-shaped cuticular thickenings. Two long, slender spicules, strongly denticulate on their lower surfaces near the tips. A "roof-shaped" accessory piece prescnt. A single preanal supplementary organ present 
in the malc, and a series of button-like, bristle-bearing prominenees.

Hab. Marine.

Genotype: H. laticollis Marion, 1870.

Marion, 1870, Ann. Sci. Nat., Paris, Zool., (5) xiii, Art. 14, 18.

If this be a valid genus, it will require to be renamed on account of the previous use of Heterocephalus. As, however, its status is at present uncertain, we refrain from introducing a fresh complication into the synonymy.

\section{b. Enoplostoma Marion, 1870.}

Body short and stout, especially anteriorly. Head with numerous circumoral papillae and a crown of very stont, recurved bristles. Buceal cavity rather small, armed with three euticular "pieces" of peeuliar shape. Oeelli present. Male with a single preanal supplementary organ. Spicules short and thick, with serrated inner border. Two pairs of accessory pieces present.

Hab. Marine.

Genotype : (by page precedence) E. hirtum Marion, 1870.

Marion, 1870, Ann. Sci. Nat., Paris, Zool., (5) xiii, Art. 14, 22.

\section{c. Lasiomitus Marion, 1870.}

Body elongate, with numerous bristles, sometimes arranged in bunches, and longer and thicker near the head and cloacal aperture. Head rounded in front. Buccal capsule narrow, its wall strengthened by two long, slender chitinoid structures which are expanded in front and behind. Two ocelli, with lenses, present at the level of the base of the bueeal eapsule. Oesophagus simple, slightly enlarged behind. Tail conical. Male sometimes with a series of setiform preanal papillac. Spicules relatively long and slender, bent at an obtuse angle or almost at right angles. Accessory picee absent. Female genital organs undescribed. Spinneret present.

Hab. Marine.

Genotype : L. exilis Marion, 1870.

Marion, 1870, Ann. Sci. Nat., Paris, Zool., (5) xiii, Art. 14, 11 ; and 1870, xiv, Art. I, 8.

\section{d. Rhabdocoma Cobb, 1920.}

Cuticle thin, unstriated, without bristles except at anterior end. Head not distinct. Three lips, six labial papillae, six jointed cephalic bristles and four eervical bristles present. Lateral organs circular. Pharynx small, with three small, possibly transversely ribbed, thickenings in its wall. Oesoph- 
agus without median or posterior swelling. Tail tapering. Male with twelve to sixteen papilliform preanal supplementary organs and a second series of about eight such organs in the cervieal region. Spicules rather short and broad. Two poorly-developed aceessory pieces present. Testes paired, opposed, outstretched. Female genital tubes paired, opposed, with short, rudimentary, anterior branch and reflexed posterior branch.

Hab. Marine (in sand).

Genotype: R. americanum Cobb, 1920.

Cobb, 1920, Contr. Sci. Nematol., ix, 252 and key.

\section{Order II. STRONGYLOIDEA Weinland, IS58.}

Males with a terminal or subterninal caudal bursa, supported by a system of rays eonsisting typieally of six paired main rays and a median unpaired dorsal ray with accessory branehes. Oesophagus more or less club-shaped, without a posterior bulb.

\section{Fam. 1. STRONGYLIDAE Baird, 1853.}

Buccal eapsule well developed; its anterior margin without teeth or cutting-plates, but usually bearing a leaf-crown.

\section{Subfam. 1. STRONGYLINAE Railliet, 1893.}

Buecal eapsule relatively large, more or less subspherical or infundibular. Dorsal gutter usually well developed, forming a ridge in the wall of the buecal eapsule and extending nearly to its anterior margin. Parasites of the alimentary tract of Vertebrates.

\section{Strongylus Müller, I7SO.}

Syn. Sclerostoma Rudolphi, 1809, et auctt.; Sclerostomum, anctt.

Elements of external leaf-cromn numerous. Internal leafcrown usually absent. Buecal eapsule eup-shaped, thickwalled, with an external eireular ridge immediately behind its anterior border. 'Teeth may be present towards the base of the capsule. Dorsal gutter strongly developed. Bursa of male small, entire. Spieules not barbed. Uterine branches opposed.

Hab. Large intestine of Equidae and Elephants.

Genotype: S. equinus Müller, 1780, of Looss, 1900. 
Müller, 1780, Zool. Dan., ii, Pl. 42; Looss, 1900, Centralbl. f. Bakt., (I) xxvii, 150; Ihle, 1922, Rep. Comm. Sclerostom. Holland, I, Zool. i, 19.

The genus has been divided into the following subgenera:

\section{la. Subgen. Strongylus Railliet, 1923.}

Buccal capsule with two dorsal and two subventral teeth at its base. Genital cone strongly developed. An accessory piece present.

Hab. Large intestine of Equidae.

Type-species : S. (Strongylus) equinus Müller, 1780, of Looss, 1900.

Railliet, 1923, Réc. Méd. vét., xcix, 380.

1b. Subgen. Alfortia Railliet, 1923.

An internal leaf-crown present. Buceal capsule without teeth. Genital cone well developed. An accessory piece present.

Hab. Large intestine of Equidae.

Type-species: S. (Alfortia) [Sclerostoma] edentatus (Looss, 1900).

Railliet, 1923, Réc. Méd. vét., xcix, 381.

lc. Subgen. Delafondia Railliet, 1923.

Buccal capsule with two dorsal teeth towards its base. Genital cone very fcebly developed. An accessory piece present.

Hab. Large intestine, of Equidae.

Type-speeies : S. (Delafondia) [Sclerostoma] vulgaris (Looss, 1900).

Railliet, 1923, Réc. Méd. vét., xcix, 386.

1d. Subgen. Decrusia Lane, 1914.

Mouth subterminal, facing slightly dorsally. Bueeal capsule with two subventral teeth at its base. Accessory piece absent.

Hab. Large intestine of Indian Elephant.

Type-speeies : S. (Decrusia) [Strongylus] additicta (Railliet, Henry \& Bauehe, 1914).

Railliet, Henry \& Bauche, 1914, Bull. Soc. Paith. exot., Paris, vii, 30, 132; Lane, 1914, Ind. Journ. Med. Res., ii, 386 ; Railliet, 1923, Réc. Méd. vét., xcix, 394. 


\section{Triodontophorus Looss, 1902.}

Syn. Triodontus Looss, 1900, nec Westwood, 1845.

External and internal leaf-crowns present, their elements of equal number. Buccal capsule almost globular, rather small, but with relatively thick walls. Dorsal gutter present. From the oesophageal fumnel three pairs of teeth project into the buccal capsule. Spicules terminate in small hooks. Vulva relatively close to the posterior end of the body. Uterine branches parallel.

Hab. Large intestine of Equidae.

Genotype: T. [Triodontus] minor (Looss, 1900).

Looss, 1900, Centralbl. f. Balit., (1), xxvii, 153; 1902, Rec. Egypt. School Trop. Med., Cairo (1901), 78; Ihle, 1922, Rep. Comm. Sclerostom. Holland, I, Zool. i, 26.

\section{Craterostomum Boulenger, 1920.}

This genus differs from Triodontophorus in the absence of teeth in the oesophageal fumel, in the fact that the elements of the external leaf-crown are fewer in number than those of the internal leaf-crown, and in the somewhat more anteriorly placed vulva.

Hab. Large intestine of Equidae.

Genotype: C. [Cylicostomum] acuticaudatum (Kotlán, 1919) (=C. temuicaudatum Boulenger, 1920).

Kotlán, 1919, Közlem. összehas. élet-és körtan köréböl, Budapest, XV; Boulenger, 1920, Parasitol., xii, 105; Ihle, 1922, Rep. Comm. Sclerostom. Holland, I, Zool. i, 33.

\section{Codiostomum Railliet \& Henry, 1911.}

External and internal leaf-crowns present. Buceal capsule large, subglobular, without teeth, but with a well-developed dorsal gutter. Dorsal lobe of bursa placed almost at right angles to the main axis of the body. Prebursal papillae present, situated in the bursa itself. Lateral and ventral rays appear to arise from a common trunk. Externo-dorsal leaves dorsal ray very high up, almost at its root. Dorsal ray cleft for about half its length. An accessory branch, which divides into two, leaves each branch of the main stem high up. Accessory piece absent. Vulva close to anus. The cuticle in the neighbourhood of the vulva may be inflated to form a sheath over a portion of the tail. Uterine branches parallel.

Hab. Caeca of Ostrich (one species known).

Genotype: C. [Sclerostoma] struthionis (Horst, 1885).

Horst, 1885, Notes Leyden Mus., vii, 263; Railliet \& Henry, 1911, Bull. Soc. nat. Acclim., Paris, 574; Monnig, 1924, 
9th and 10th Rep. Dir. Vet. Educ. and Res., Pretoria (1923), $45 \mathrm{~s}$.

5. Oesophagodontus Railliet \& Henry, 1902.

Syn. Pseudosclerostomum Quicl, 1919.

External and internal leaf-erowns present. Mouth-collar depressed. Buccal eapsule goblet-shaped, with a circular ridge posteriorly. The lining of the oesophageal funnel is thrown into three small folds or teeth which do not project into the buccal capsule. Dorsal gutter absent. Bursa entire. Dorsal ray cleft to the point of origin of the accessory branehes. Postero-lateral ray with an aceessory branch. Vulva relatively distant from anus. Uterine branehes parallel.

Hab. Large intestine of Equidae.

Genotype: $O$. [Sclerostoma] robustus (Giles, 1892).

Giles, 1892, Sci. Mem. Med. Off. Army, India (7), 26 ; Railliet \& Henry, 1902, Compt. rend. Soc. Biol., Paris, liv, 110; Ihle, 1922, Rep. Comm. Sclerostom. Holland, I, Zool. i, 103.

\section{Equinurbia Lane, 1914.}

Fairly stout worms. External leaf-crown eomposed of numerous elements of two lengths, two short elements being placed between each pair of long elements. Mouth-opening roughly circular. Buccal capsule subglobular, with a long dorsal gutter. Externo-dorsal rays of bursa with two aeeessory branches and a dorsal boss. Dorsal ray cleft for about half its length. The externo-dorsal rays and two pairs of accessory branches of the dorsal ray spring from the median stem of that ray. Vulva prominent, close to anus. Uterine branches parallel.

Hab. Alimentary tract of Elephants.

Genotype : E. [Sclerostoma] sipunculiformis (Baird, 1S59).

Baird, 1859, Proc. Zool. Soc., London, 425; Lane, 1914, Ind. Journ. Med. Res., ii, 381.

7. Choniangium Railliet, Henry \& Bauche, 1914.

Syn. Asifia Lane, 1914.

Anterior extremity obliquely truncate, so that the mouthopening faces somewhat dorsally. External leaf-crown composed of numerous long, fine elements. Internal leaf-crown absent. Bueeal capsule elongate, narrowing posteriorly. No teeth in the buecal capsule, but paired hemispherical bosses are present on the internal surface of its wall. Dorsal gutter apparently absent. Postero-lateral ray of bursa with a well-developed accessory braneh. Externo-dorsal rays and a pair of aecessory branches of the dorsal ray both spring from the mcdian dorsal stem, the accessory branches being cleft 
almost to their bases. Main stem of dorsal ray eleft for less than half its length. An accessory piece present. 'Tail of female short and straight. Vulva close to anus. Uterine branches parallel.

Hab. Intestine of Elephants.

Genotype: C. [Sclerostomum] epistomum (Piana \& Stazzi, 1900).

Piana \& Stazzi, 1900, Arch. Parasitol., Paris, iii, 467; Railliet, Henry \& Banche, 1914, Bull. Soc. Path. exot., Paris, vii, 207; Lane, 1914, Ind. Journ. Med. Res., ii, 384.

\section{Ransomus Hall, 1916.}

Anterior end obliquely truncate, so that the mouth faces antero-ventrally. External leaf-crown present. Buceal capsule large, subglobular, without internal teeth. Anterolateral ray of bursa arises separately from the medio-lateral and postero-lateral. The latter rays are fused for about half their length. Externo-dorsal ray also originates separately. The dorsal ray gives off a pair of accessory branches, and almost immediately behind these the main stem bifureates. The eleft portion of the main stem represents approximately a quarter to a third of the length of the whole ray. Spicules long, tubular, markedly alate. An aceessory piece present. Vulva a little in front of anus. Uterine branches opposed.

Hab. Intestine of a Rodent (one speeies known).

Genotype: $R$. rodentorum [sic] Hall, 1916.

Hall, 1916, Proc. U.S. Nat. Mus., 1, 116.

\section{Subfam. 2. TRICHONEMINAE Railliet, 1916.}

Buccal capsule cylindrieal, with relatively thick walls. Dorsal gutter eomparatively short, not reaching the anterior margin of the buceal eapsule. No ventral eervical groove or cephalic vesicle. Parasites of the alimentary tract of Vertebrates.

\section{Trichonema Cobbold, 1874.}

Syn. Cyathostomum Molin, 1861, nec Cyathostoma E. Blanchard, 1849; Cyathostomum Looss, 1900; Cylicostomum Railliet, 1901, et auctt.; Cylichnostomum Looss, 1902.

External and internal leaf-crowns present. Buccal capsule rather shallow, more or less cylindrical, withont teeth. Oesophageal funnel generally well developed. Dorsal ray of bursa bifureate almost to the point of origin of the exteruodorsal rays. The two pairs of accessory branches of the dorsal ray spring from the bifureate portion and not from the median stem. Genital eone with a well-developed dermal 
collar and usually with appendages. Spicules terminating in double hooks. Vulva close to anus. Uterine branches parallel.

Hab. Large intestine of Equidae.

Genotype: T. [Cylicostomum] longibursatum (Yorke \& Macfie, 1918).

Cobbold, 1874, Veterinarian, London, xlvii, 6, 237; Mehlis, 1831, Isis (v. Oken), 79; Looss, 1900, Centralbl. f. Bakt. (I), xxvii, 150; 1902, Rec. Egypt. School Trop. Med., Cairo (1901), 36, 86; Railliet, 1901, Echo vét., Liége, xxxi, 40; Yorke \& Macfie, 1918, Ann. Trop. Med. Parasit., Liverpool, xi, 400; Ihle, 1922, Rep. Comm. Sclerostom. Holland, I, Zool. i, 37 ; Le Roux, 1924, Journ. Helminthol. ii, 115.

Since Le Roux (1924) has made use of Trichonema, there is no alternative but to acknowledge the probable correctness of that name. So far as the genotype is concerned, Le Roux points ont that $S$. tetracanthus Mehlis, 1831, cannot be identified with certainty, and therefore ceases to be a valid type. He designates $T$. longibursatum as type of the genus, since he believes that Müller's fig. 12 in Icones Zool. Dan., ii (1780), refers to a male of this species, and since he considers this to be the most common species in the horse in Europe. This definite designation of a type is undoubtedly to be preferred to further speculation concerning the probable identity of S. tetracanthus Mehlis.

This genus has been divided into the following subgenera:

\section{1a. Subgen. Trichonema Le Roux, 1924.}

Syn. Cylicostephanus Ihle, 1922.

Month-opening circular. Mouth-collar depressed. Buccal capsule usually long and cylindrical, or somewhat narrowed anteriorly. The elements of the internal leaf-crown are short rods, situated in the immediate neighbourhood of the anterior margin of the capsule. Tail of female usually straight.

Type-species : T. (Trichonema) [Cylicostomum] longibursatum (Yorke \& Macfie, 1918).

Yorke \& Macfie, 1918, Ann. Trop. Med. Parasit., Liverpool, xi, 400; Ihle, 1922, Rep. Comm. Sclerostom. Holland, I, Zool. i, 77 ; Le Roux, 1924, Journ. Helminthol., ii, 118.

1b. Subgen. Cylicostomum Ihle, 1922.

External leaf-crown consists of eighteen to twenty-four, mostly pointed, elements. Internal leaf-crown composed of thin, triangular, radially-disposed plates, whose origin extends backwards on to the internal surface of the buccal capsule some distance from its anterior margin. A "problematical structure" is present in the mouth-collar. Buccal capsule rather short, thick-walled. Tail of female straight or slightly bent dorsally. 
Type-species : T. (Cylicostomum) aegyptiacum Railliet, 1923 (=C. tetracanthum Mehlis of Looss, 1900).

Ihle, 1922, tom. cit., 39 .

\section{1c. Subgen. Cylicocyclus Ihle, 1922.}

Elements of internal leaf-crown usnally small and numerous, generally in the form of fine rods, originating in the immediate neighbourhood of the anterior margin of the buceal capsule. The posterior margin of the buceal capsule-wall forms a hooplike thiekening. Tail of female straight or only slightly bent dorsally, very seldom strongly bent.

Type-speeies: T. (Cylicocyclus) [Cyathostomum] radiatum (Looss, 1900).

Ihle, 1922, tom. cit., 63.

\section{1d. Subgen. Cylicocercus Ihle, 1922.}

External leaf-crown composed of twenty to twenty-nine elements. Elements of internal leaf-erown like those of the subgenus Cylicostomum, but the region of their origin may extend back to a great distanee from the anterior margin of the buceal capsule. Posterior end of female strongly bent dorsally, with a pre-vulvar swelling, the whole somewhat resembling a human foot when viewed laterally.

Type-species: T. (Cylicocercus) [Cyathostomum] alveatum (Looss, 1900).

Ihle, 1922, tom. cit., 50 .

le. Subgen. Cylicodontophorus Ihle, 1922.

Elements of external leaf-erown generally small and numerous; those of the internal leaf-crown very large and broad when seen from outside. The latter are plates, radially disposed, originating not far behind the anterior margin of the buccal capsule. Buccal capsule short and wide, thick-walled. Tail of female generally straight. Vulva often rather distant from anus.

Type-speeies: T. (Cylicodontophorus) [Cyathostomum] bicoronatum (Looss, 1900).

Ihle, 1922, tom. cit., 86.

2. Poteriostomum Quiel, 1919.

Syn. Hexodontostomum Ihle, 1920.

Elements of external leaf-erown numerous, those of the internal leaf-crown large and broad when seen from outside. Sometimes six of the latter elements are longer than the rest. Postero-lateral ray of bursa has an accessory branch. The 
externo-dorsal ray and the two branches of the dorsal ray leave the main stem in its anterior half, and run almost at right angles to it. The median dorsal ray is bifurcate only as far as the point of origin of the more posterior of the two pairs of accessory branches. Tail of female long, straight and free from swellings.

Hab. Large intestine of Equidae.

Genotype : P. imparidentatum Quiel, 1919.

Quiel, 1919, Centralbl. $f$. Bakt. (I), lxxxiii, 466; Ihle, 1920, Centralbl.f. Bakt. (I), lxxxiv, 43 ; 1922, Rep.Comm. Sclerostom. Holland, I; Zool. i, 98.

\section{Murshidia Lane, 1914.}

(For questions of synonymy sce discussion under Pteridopharynx, infra).

Body tapering anteriorly. In the male the thickest portion of the body may be just anterior to the bursa. Mouth-collar well defined, incised dorsally and ventrally. External leafcrown composed of numerous fine elements originating along a curved line which runs closer to the anterior margin of the buccal capsule dorsally and ventrally. The dorsal and ventral elements are also shorter than the lateral, thus giving to the mouth the shape of a dorso-ventral slit. No teeth at base of buccal capsule. Antero-lateral ray of bursa divergent from the remaining lateral rays. The externo-dorsal ray may have a dorsal boss or a small accessory branch. It lies relatively close to the postero-lateral ray, which also is furnished with a dorsal boss. Dorsal ray cleft to the origin of the accessory branches, of which there are typically two pairs. Spicules long and slender. An accessory piece present. Vulva close to anus. Uterine branches parallel.

Hab. Alimentary tract of Elephants and Wart-hogs.

Genotype: M. murshida Lane, 1914.

Lane, 1914, Ind. Journ. Med. Res., ii, 387.

\section{Pteridopharynx Lane, 1921.}

\section{Syn. Memphisia Khalil, 1922.}

Slender forms. External leaf-crown composed of numerous elements which may be of uneven length. Buccal capsule more or less cylindrical, with two or more small teeth projecting from its base. The sectors of the oesophagus may be plumose intermally. Postero-lateral ray of bursa with a dorsal boss or an accessory branch. Externo-dorsal ray typically with a similar boss or accessory branch. The two pairs of accessory branches of the dorsal ray fused throughout the greater part of their length. Median stem of dorsal ray cleft for about one-third of its length or about half-way to the 
point of origin of its accessory branches. Vulva close to anus. Uterine branches parallel.

Hab. Alimentary canal of Elephants and Rhinoceroses.

Genotype: P. africana Lane, 1921.

Lane, 1921, Ind. Journ. Med. Res., ix, 165; Khalil, 1922, Proc. Zool. Soc., London, 212; Ware, 1924, Journ. Comp. Path. Ther., xxxvii, 282; Neveu-Lemaire, 1924, Ann. Paras. hum. el comp., Paris, ii, 134, 138, 142.

Khalil (1922) separated Memphisia from Pteridopharynx on account of the presence of a well-defined cutieular. collar just behind the mouth-eollar, and of the occurrence of an accessory branch on the externo-dorsal ray of the bursa. The cuticular collar, however, is extremely poorly developed in the seeond speeies ( $M . a \approx i \approx \alpha)$ assigned to the genus by Khalil. So far as the presence of an aecessory branch or boss on the externodorsal ray is concerned, the figures of Lane (1921) and Ware (1924) show that such a branch may be present in species of Pteridopharynx totally without the cuticular collar already mentioned. In fact there is a boss or rudimentary branch also in most species of Murshidia. In our opinion Memphisia and Pteridopharynx cannot be distinguished from each other, and the presence of the cuticular collar can only be considered as of speeific importance.

The genus Pteridopharynx is very elosely related to Murshidia. It differs from the latter genus in the presence of teeth at the base of the buccal capsule and in the form of the dorsal ray of the bursa. In Murshidia the main dorsal stem is cleft right to the origin of the two pairs of accessory branches, which are well separated from each other for the greater part of their length; whereas in Pteridopharynx the dorsal ray is cleft for only half the distance between its tip and the origin of the accessory branches, which are fused for the greater part of their length. The dorsal lobe of the bursa is particularly elongate in Pteridopharymx, while in Murshidia the whole bursa is short and stunted. The recently-described genera Henryella Neveu-Lemaire, 1924, and Buissonia NeveuLemaire, 1924, appear to resemble Murshidia in the absence of teeth at the base of the buecal capsule, but approach more elosely to Pteridopharynx in the arrangement of the dorsal ray. They thus form a connecting-link between Murshidia and Pteridopharymx, and it appears probable that further investigation will show that not only Neveu-Lemaire's genera, but also Pteridopharynx, eannot be generically separated from Murshidia.

5. Gyalocephalus Looss, 1900.

External and internal leaf-crowns present. Buecal capsule more or less eylindrical, with thick walls which, decreasing in 
thickness posteriorly, are prolonged as delicate triangular plates over the anterior portion of the oesophageal funnel. Three wedge-like septa or "teeth" project from the funnel into the buccal capsule. Dorsal gutter absent. Prebursal papillae very long and ray-like, within the bursa proper. Dorsal ray cleft almost to origin of externo-dorsal rays. Two accessory branches spring from each branch of the dorsal ray.

Hab. Large intestine of Equidae.

Genotype : G. capitatus Looss, 1900.

Looss, 1900, Centralbl. f. Bakt. (I), xxvii, 191 ; Ihle, 1922, Rep. Comm. Sclerostom. Holland, I, Zool. i, 105.

\section{Amira Lane, 1914.}

Syn. Khalitia Neven-Lemaire, 1924.

Cuticle thick, sometimes with bosses in front of the bursa in the male. External and internal leaf-crowns present. Buccal capsule very shallow, with thick walls. Oesophagus hourglassshaped, with a large oesophageal fumnel and lined almost throughont with thickened cuticle. Dorsal lobe of bursa may be enormously elongate. Prebursal papillae long and slender, appearing as additional rays. All the bursal rays relatively long and slender, more particularly the dorsal, which is cleft almost to its base. Accessory branches of dorsal ray typically two pairs, arising from the bifurcate portion. One pair may be much reduced. Spicules extremely long and filiform. An accessory piece present. Vulva close to anus. Uterine branches parallel.

Hab. Alimentary tract of Elephants.

Genotype: A. [Cylicostomum] pileata (Railliet, Henry \& Bauche, 1914).

Railliet, Henry \& Bauche, 1914, Bull. Soc. Path. exot., Paris, vii, 208; Lane, 1914, Ind. Journ. Med. Res., ii, 394; and 1915, iii, 107.

\section{Quilonia Lane, 1914.}

Syn. Evansia Railliet \& Henry, 1913, nec Scott, 1906; Nematevansia Thle, 1919; Paraquilonia Neveu-Lemaire, 1924.

Extemal leaf-crown composed of a few long elements. Internal leaf-crown present or absent. Buccal capsule a wide, shallow ring, its wall widely separated from the mouth-cavity, which is bounded by the elements of the leaf-crowns. The latter extend backwards and become continuous with the cuticle lining the oesophageal funnel. There may be teeth at the base of the buccal capsule. Lateral rays of bursa rather divergent from each other. Externo-dorsal rays spring from the median stem of the dorsal ray near its base. Dorsal ray cleft for about one-third of its total length. Two small 
accessory branches originate together from each branch. An accessory piece present. Vulva in posterior third of body. Uterine branches opposed, but the posterior branch turns and runs anteriorly.

Hab. Intestine of Elephants and Rhinoeeroses.

Genotype: Q. [Evansia] renniei (Railliet \& Henry, 1913).

Railliet \& Henry, in Railliet, Henry \& Joyeux, 1913, Bull. Soc. Path. exot., Paris, vi, 264; Lane, 1914, Ind. Journ. Med. Res., ii, 391 ; Neveu-Lemaire, 1924, Ann.Paras.hum. et comp., Paris, ii, 122.

8. Bourgelatia Railliet, Henry \& Banehe, 1919.

External leaf-erown composed of about twenty large, pointed elements. Internal leaf-crown with about forty elements. Buceal capsule shallow, eylindrieal, its wall in two thick portions, of which the posterior is more or less continuous with the cuticular lining of the wicle, shallow oesophageal funnel. Ventral rays of bursa parallel and elosely applied to eaeh other. Bursa incised near the tips of the ventral rays, giving the appearance of a pair of additional lobes. Anterolateral ray somewhat shorter than, but not divergent from, the remaining lateral rays. Externo-dorsal ray originates high up on the main dorsal stem. Dorsal ray eleft for almost half its length. A single aecessory branch springs from each main branch. An indistinct aceessory piece present. Vulva close to anus. Uterine branches parallel.

Hab. Intestine of Pigs (one species known).

Genotype: B. diducta Railliet, Henry \& Bauche, 1919.

Railliet, Henry \& Bauehe, 1919, Bull. Soc. Path. exot., Paris, xii, 324.

Raillet, Henry \& Banche suggest that this form belongs to the Oesophagostominae, in spite of the absence of a ventral cervical groove. Certainly the single pair of aceessory branches of the dorsal ray suggests relationship with the Oesophagostomes, in which the second pair of accessory branehes is much redueed or absent, but since the grouping of that subfamily has been based almost entirely on the presence of a ventral groove, we have no alternative but to include the genus under diseussion in the Triehoneminae, at the same time remarking that it is perhaps the nearest relative of the Oesophagostominae.

\section{Kiluluma Skrjabin, 1916.}

Mouth-collar divided by grooves into six sections, each bearing one of the eephalic papillae. An external leaf-crown of six elements present, these arising from the base of the buccal capsule and projecting from the mouth-opening. 
Buecal capsule shallow, cylindrical, with thick walls. Prebursal papillae of male appear as an additional pair of ventral rays within the bursa. Externo-dorsal rays originate high up on the median dorsal stem. Dorsal ray with one pair of accessory branches, also arising high up on the median stem. The tips of these branches may be bifureate. Spicules broad, alate, and twisted distally. An accessory piece present. Vulva near the anus. Uterine branehes parallel.

Hab. Alimentary tract of Rhinoceroses.

Genotype : K. [Deletrocephalus] stylosa (v. Linstow, 1907).

v. Linstow, 1907, Mitt. Zool. Mus. Berlin, iii, 254; Skrjabin, 1916, Sci. Res. Zool. Exp. Brit. E. Africa (Dogiel and Solsolow), Petrograd, i (4), 44.

\section{Cylindropharynx Leiper, 1911.}

External leaf-crown composed of six very large elements, three on eaeh side. Dorsally and ventrally there projects from the mouth-opening a broad plate direeted towards the main axis of the body. Internal leaf-crown consists of twelve large elements, arising from the anterior margin of the buccal capsule. Buccal capsule extremely long, cylindrical, thickwalled. Dorsal ray of bursa cleft almost to origin of externodorsal rays. An aceessory branch, bifurcate at its tip, springs from each of the main branches of the dorsal ray.

Hab. Large intestine of Equidae.

Genotype : C. brevicauda Leiper, 1911.

Leiper, 1911, Proc. Zool. Soc., London, 551; Yorke \& Maefie, 1920, Ann. Trop. Med. Parasit., Liverpool, xiv, 169; Ihle, 1922, Rep. Comm. Sclerostom. Holland, I, Zool. i, 108.

\section{Trachypharynx Leiper, 1911.}

An external leaf-erown present. The anterior third of the bueeal eapsule is thickly reinforeed with chitinoid material. The posterior two-thirds are surrounded by the oesophageal museulature and thinly lined with chitinoid material bearing internally-projecting knobs. Vulva a little in front of anus.

Hab. Intestine of a large Rodent (one species known).

Genotype: $T$. nigeriae Leiper, 1911.

Leiper, 1911, Proc. Zool. Soc., London, 552 ; Hall, 1916, Proc. U.S. Nat. Mus., 1, 109.

\section{Eucyathostomum Molin, 1861.}

Buccal capsule large, with wide anterior opening whose internal border is armed with a leaf-crown consisting of numerous slender, pointed elements. Bursa with projecting dorsal lobe. Ventral and lateral rays arising from a common trunk. The ventral rays may be fused. Dorsal ray may be

SYN. NEM. 
cleft almost to its origin, or its main branehes may appear to be fused almost to the tip. There are externo-dorsal rays and two pairs of aceessory branches. The latter spring from the branehes of the main dorsal ray. Spienles long, filiform, equal. Tail of female aentely pointed. Vulva close to anus.

Hab. Intestine of Ruminants.

Genotype: E. longesubulatum Molin, 1861.

Molin, 1861, Mem. R. Ist. Veneto, ix, 435, 455; Ransom, 1911, U.S. Dept. Agric., Bur. Anim. Indust. Bull. 127, 38.

This genus is insufficiently known.

\section{Deletrocephalus Diesing, 1851.}

External leaf-crown composed of six elements, fibrous and opaque, "dilated at each end," converging in front. Mouth terminal, suborbieular. Bursa exeised, with many rays. Tail of female pointed, straight. Vulva near anus.

Hab. Alimentary tract of Rhea.

Genotype: D. dimidiatus Diesing, 1851.

Diesing, 1851, Systema Helminthum, ii, 298 ; 1855, Denkschr. k. Akad. Wiss., Wien, ix, 183.

This genus is insufficiently charaeterized. It is uncertain whether the forms deseribed as $D$. dimidiatus by later authors were identieal with Diesing's speeies.

\section{Cloacina v. Linstow, 1898.}

Cuticle with prominent transverse striations. Lateral fields so highly developed as sometimes to meet in the middle axis of the body. Head with six lips, a dorsal, a ventral and four submedian, each of the latter bearing a projeeting, elubshaped papilla. Buecal eapsule a shallow ring. An internal leaf-crown apparently present. Bursa entire, almost cireular. Dorsal ray bifureate for about two-thirds of its length, each braneh bearing a short accessory branch. Externo-dorsal rays originate separately from the dorsal ray. Postcro-lateral and medio-lateral rays elosely apposed ; antero-lateral widely separated from them. Latero-ventral and ventro-ventral rays elosely apposed. Spicules very long. Tail of female tapering, eurved dorsally. Vulva very elose to anus.* Uterine branches parallel.

Hab. Alimentary canal of Kangaroo.

Genotype: C. dahli v. Linstow, 1898.

v. Linstow, 1898, Arch.f. Naturg., lxiii, i, 286; Railliet \& Henry, 1912, Arch. Parasitol., Paris, xiv, 563; 1913, Bull. Soc. Path. exot., Paris, vi, 506.

* von Linstow describes the vulva as opening with the anus into a common cloaca. According to Railliet \& Henry (1913), however, this is inaccurate. 


\section{Zoniolaimus Cobb, 1898.}

The only available description of the type of this genus is contained in the figures given by Cobb, with their legend, and a "formula." According to Railliet \& Henry (1913, Bull. Soc. Path exot., Paris, vi, 506), the genus is synonymons with Cloacina v. Linstow, and this may very possibly be the case. The arrangement of the bursal rays is apparently the same in both genera, but according to Cobb's figures the cephalic papillae in Zoniolaimus are bristle-like and slender, not clubshaped; while the oesophagus appears to possess a median and a posterior bulb (possibly only dilatations of the lumen), and a ring-shaped buccal capsule is not indicated.

Hab. Alimentary canal of a Kangaroo.

Genotype: $Z$. setifera Cobb, 1898.

Cobb, 1898, Agric. Gaz. N.S.W., Sydney, ix, 312.

\section{Subfam. 3. OESOPHAGOSTOMINAE Railliet, 1915.}

Buccal capsule cylindrical, or large and subglobular. A transverse ventral cervical groove present. The cuticle of the anterior end may be dilated to form a cephalic vesicle, limited ventrally by the cervical groove. Parasites of the alimentary tract of Mammals.

\section{Oesophagostomum Molin, 1861.}

Syn. Hypostomum Stewart, 1898.

Anterior end usually with a cuticular inflation or vesicle limited bchind, at about the level of the excretory pore, by a transverse ventral groove. This groove extends for a varying distance on to the lateral surfaces of the worm. Lateral cervical alae may be present, originating at the level of the groove. An external leaf-crown present. Internal leafcrown present or absent. Oesophageal funnel occasionally with three teeth. Medio-lateral and postero-lateral rays of bursa closely applicel to each other and somewhat divergent from the antero-lateral ray. Externo-dorsal arising high up on the main stem of the dorsal ray, which is bifurcate in its posterior two-fifths. A much-reduced accessory branch arises from each of the main branches. The sccond pair of accessory branches is occasionally represented by a minute, slender branch on each side posterior to this. An accessory piece present. Vulva near anus. Uterine branches parallel.

Hab. Intestine of Mammals.

Genotype: O. [Strongylus] dentalum (Rudolphi, 1803).

Ruclolphi, 1803, Arch.f. Zool. u. Zoot., Brunswick, iii, 12; Molin, 1861, Mem.R. Ist. Veneto, ix, 435, 443; Ransom, 1911, 
U.S. Dept. Agric., Bur. Anim. Indust. Bull. 127, 40; Railliet \& Henry, 1913, Bull. Soc. Path. exot., Paris, vi, 506-7.

Railliet \& Henry (1913) proposed the subgenera Proteracrum and Hysteracrum for the reception of the species of this genus occurring in Ruminants, while Thle (1922, Bijdr. Dierk. Natura Artis Magistra, Amsterdam, xxii, 92) has proposed a subgenus Conoweberia for the species $O$. apiostomum and $O$. brumpti. The subgenus Proteracrum, of which O. columbianum is apparently to be considered the type, differs from the type of the genus in the slighty-swollen cephalic resicle and in the presence of cervical alae. Hysteracrum, with O. venulosum as type, differs in the post-oesophageal situation of the cervieal papillae. Conoweberia is defined as having a buccal capsule shaped like a truncate cone, and having three teeth in the oesophageal fumnel. Goodey (1924, Journ. Helminthol., ii, 97) has expressed the opinion that such a division into subgenera is unnecessary, and we are in agreement with this view.

\section{Ternidens Railliet \& Henry, 1909.}

Ventral cervical groove present, but no cephalic vesicle. External and internal leaf-crowns present. Mouth opens obliquely towards the clorsal side. Buccal capsule subglobular, with three prominent, bifid teeth projecting from the oesophageal fumnel.

Hab. Intestine of Primates (one species known).

Genotype: T. [Triodontophonts] deminutus (Railliet \& Henry, 1905).

Railliet \& Henry, 1905, Bull. Mus. Hist.nat., Paris, xi, 269; 1909, Compt. rend. Soc. Biol., Paris, lxvi, 169; 1912, Arch. Parasitol., xiv, 564, 577.

\section{Chabertia Railliet \& Henry, 1909.}

Anterior end obliquely trmeate, so that the mouth faces antero-ventrally. Ventral cervical groove faint. A trace only of a cephalic vesicle, just in front of the ventral groove. Much-reduced external and internal leaf-erowns present, just behind the anterior margin of the buceal capsule. Buccal capsule large, subglobular, without teeth. Spicules long, tubular, slender. An accessory piece present.

Hab. Intestine of Ruminants (one species known).

Genotype: C. [Strongylus] ovina (Gmelin, 1790).

Gmelin, 1790, Syst. Nat., 13th ed., i, Pt. VI, 3044 ; Fabrieius, 1794, Entomologia Sistematica, 5; Railliet \& Henry, 1909, Compt. rend. Soc. Biol., Paris, lxvi, 169; Ransom, 1911, U.S. Dept. Agric., Bur. Anim. Indust. Bull. 127, 35. 
Subfam. 4. STEPHANURINAE Railliet, Henry \& Bauche, 1919.

Buccal capsule well developed, cup-shaped, with a lcaf-crown at its anterior margin. Bursa of male subterminal and poorly developed, with stunted rays. Parasitic in the perirenal tissue or kidneys, less commonly in the liver and lungs, of Mammals.

\section{Stephanurus Dicsing, 1839.}

A relatively stout form. Mouth circular, provided with an external leaf-crown of small clements. Cuticle surrounding the mouth reflected externally into six thickenings or "epanlettes," two median and four submedian. Buccal capsule cup-shaped, with thick walls. At its base there aro six teeth which may be bicuspid or tricuspid. Rays of bursa short and stout. Dorsal ray divides into two branches which are bifurcate or trifurcate at their tips. Lateral rays closely applied to each other, the postero-lateral thicker than the other two. Spicules equal or subequal. An accessory piece present. Tail of female short, abruptly attenuated behind the anus, and bearing a pair of lateral globular cuticular processes. Vulva close to anus. Uterine branches parallel. The intestine is considerably longer than the body, and is therefore convoluted.

Hab. Perirenal fat, liver, abdominal viscera and, more rarely, lungs of Pigs; liver of cattle (one species known).

Genotype: S. dentatus Diesing, 1839.

Diesing, 1839, Ann. Wien. Mus. Naturg., ii, 232; Taylor, 1899, 16th Ann. Rep. Bur. Anim. Indust., Washington, 612; Daubney, 1922, Journ. Comp. Path. Ther., xxxvi, 97.

\section{Subfam. 5. SYNGAMINAE nov.}

Buccal capsule well developed, subglobular, without leafcrowns at its anterior margin, but with tecth at its base. Eggs operculate. Parasites of the respiratory tract of Birds and Mainmals.

\section{Syngamus v. Siebold, 1836.}

Sexes joined permanently in copula. Buccal capsule large, furnished at its basc with eight or nine teeth. Bursa of male thick-walled, fleshy, its rays short and stout. Spicules small, in some species extremely small and difficult to detect. Vulva in anterior third of body.

Hab. Respiratory tract of Birds and Mammals.

Genotype : S. [Fasciola] trachea (Montagu, 1811) $(=S$. trachealis v. Siebold, 1836). 
Montagu, 1811, Mem. Werner. Nat. Hist. Soc., Edinburgh, i, 176; v. Siebold, 1836, Arch. f. Naturg., ii, 105; Chapin, 1925, Journ. Agric. Res., Washington, xxx, 558.

2. Cyathostoma E. Blanchard, 1849.

Sexes not permanently joined in copula. Buccal capsule large, cup-shaped, with six or seven teeth at its base. Externodorsal rays of bursa leave median dorsal stem high up, almost at its root. Dorsal ray cleft for about one-third of its total length. Spicules long and filiform. An accessory piece may be present. Vulva in the middle or anterior third of the body.

Hab. Respiratory tract of Birds.

Genotype: C. lari E. Blanchard, 1849.

E. Blanchard, 1849, Ann. Sci. nat., Paris, Zool., iii, 182; Chapin, 1925, Journ. Agric. Res., Washington, xxx, 565.

\section{Fam. 2. ANCYLOSTOMIDAE (Looss, 1905) Lane, 1917.}

Buccal capsule relatively well developed,* infundibular, bearing rentral teeth or cutting-plates on its anterior margin. Accessory branches of dorsal ray much reduced.

\section{Subfam. 1. ANCYLOSTOMINAE (Looss, 1905) Stephens,} 1916.

Anterior margin of buccal capsule armed vontrally with from one to four pairs of teeth.

1. Ancylostoma $\uparrow$ (Dubini, 1843) Creplin, 1845.

Syn. Diploodon Molin, 1861.

Anterior end bent dorsally. Mouth-opening guarded by one to three pairs of ventral teeth. Buceal eapsule deep, infundibular, provided internally with two triangular dorsal teeth. Dorsal gutter traverses the dorsal wall of the capsule and opens in a rleep noteh on its anterior margin. Bursa with a small dorsal lobe. Externo-dorsal rays arise high up from median stem of dorsal ray. The latter is eleft for about one-third of its length. The terminations of the main branches appear tridigitate, i.e. there are two very short accessory branches close to the tip of each. Spicules not barbed. An accessory piece present. Vulva behind the middle of the body. Uterine branches opposed.

* The structure of the buccal capsule in Agriostomum suggests that not improbably the buccal capsule in the Ancylostomiclae represents in reality a buccal capsule and oesophageal funnel combined.

$\dagger$ The spelling Ancylostoma has been adopted by the International Commission on Zoological Nomenclature. The name was spelt Agchylostoma by Dubini, and there are numcrous other variants, which we have not considered it necossary to give in the synonymy. 
Hab. Intestine of Mammals.

Genotype: A. duodenale Dubini, 1843.

Dubini, 1843, Ann. Univ. Med., Milan, evi, 5; Looss, 1911, Rec. Egypt. School Trop. Med., Cairo, iv, 252; Lane, 1916, Ind. Journ. Med. Res., iv, 76.

Lane (1916) has proposed to divide the genus into two subgenera, Ancylostoma for forms with three pairs of ventral teeth, viz. A. duodenale and A. caninum; and Ceylancylostoma for forms with two pairs, viz. A. ceylanicum and $A$. malayanum. He considers that the form of the lateral rays of the bursa is correlated with the number of ventral teeth. The subdivision of the genus, however, appears unnecessary.

\section{Galoncus Railliet, 1918.}

Anterior end bent dorsally. Mouth-opening guarded by two or three pairs of ventral tceth. Buccal capsule very much reduced in size, cup-shaped and imperfectly ehitinized, with one or two pairs of teeth towards its base. Bursa with a small dorsal lobe. Externo-dorsal ray arises from the main stem of the dorsal ray. The cleft portion of the dorsal ray is extremely short in eomparison with its total length. Its terminations are tridigitate, i.e. there are two accessory branches on each branch. Spicules long, filiform, apparently united at their tips. An accessory piece present. Vulva towards the posterior fourth of the body. Uterine branches opposed.

Hab. Submucous cysts in the intestine of Felidae.

Genotype: G. [Ankylostomum] perniciosus (v. Linstow, 1855).

v. Linstow, 1855, Arch.f. Naturg., li, i, 238; Railliet, 1900, Arch. Parasitol., Paris, iii, 91; 1918, Bull. Soc. Path. exot., Paris, xi, 82.

\section{Agriostomum Railliet, 1902.}

Mouth-opening cireular, guarded by four pairs of marginal teeth. Dorsal gutter ends in a cone, bifid at its tip and projeeting freely. In front of the teeth there are indieations of a primitive leaf-crown. Buceal capsule short, more or less cylindrical. Oesophageal funnel much dilated, with thiekened wall. The buccal capsule proper and the oesophageal funnel together have much the shape of the buceal capsule of a typical Ankylostome. Antero-lateral ray of bursa thieker than, and somewhat divergent from, the remaining lateral rays. Externo-dorsal rays spring from the median dorsal stem about half-way between its root and its bifureation. Dorsal ray cleft for about one-third of its length. Its terminations are bidigitate. Spicules equal, alate. An accessory 
piece present. Vulva close to anus. Uterine branches parallel.

Hab. Alimentary traet of Bos indicus. (One species known).

Genotype: A. vryburgi Railliet, 1902.

Railliet, 1902, Compt. rend. Soc. Biol., Paris, liv, 107; Lane, 1923, Parasitol., xv, 351; Ware, 1925, Journ. Comp. Path. Ther., xxxviii, 83.

Lane suggests that this genus forms an interesting link between the Aneylostomidae and the Oesophagostominae, and proposes to place it in a separate subfamily, Agriostominae. While we are in agreement with the first of these suggestions, we prefer to retain the genus in the Aneylostominae.

\section{Strongylacantha van Beneden, 1873.}

Anterior extremity bent slightly towards the rentral side, the mouth-opening being obliquely ventral. Buecal capsule small. From the ventral border of the mouth protrude laterally and posteriorly two large, hook-like teeth. Within the dorsal border there is a small, conical, median tooth. Bursa short. Externo-dorsal rays originate at the base of the dorsal ray. Dorsal ray usually undivided, terminating in six small branches, the arrangement of which is subject to much variation. Spieules short, bifurcate in their distal halves. An aceessory piece present. Vulva slightly in front of the posterior third of the body. Uterine branches opposed.

Hab. Intestine of Bats.

Genotype: S. glycirrhiza van Beneden, 1873.

van Beneden, 1873, Mém. Acad. Roy. Sci. Belg., xl, (1), 13; Seurat, 1920, Bull. Mus. Hist. nat., Paris, xxvi, 618; 1921, Bull. Soc. Hist. nat. Afrique du Nord, Alger, xii, 202.

\section{Subfam. 2. NECATORINAE Lane, 1917.}

Anterior margin of buceal eapsule usually bearing ventral eutting-plates, but without teeth.

\section{Necator Stiles, 1903.}

Anterior end bent dorsally. Mouth-opening gnarded by a pair of ventral eutting-plates. Buceal eapsule large, infundibular. At its base a pair of ventral lancets, a pair of subdorsal teeth and a prominent dorsal cone projecting into the lumen and earrying the dorsal gutter. Bursa with two large lateral lobes and a small dorsal lobe. Externo-dorsal rays relatively long and slender, arising high up on the main dorsal stem. Dorsal ray eleft for almost half its length. Its terminations 
are bidigitate, i.e. there is a single pair of accessory branches. Spicules slender, barbed. Vulva slightly in front of the niddle of the body. Uterine branches opposed.

Hab. Intestine of Primates, Pigs and Rhinoceroses.

Genotype: N. [Uncinaria] americanus (Stiles, 1902).

Stiles, 1902, Amer. Med., Philadelphia, iii, 777 ; 1903, Journ. Amer. Med. Ass., Chicago, xli, 312; Looss, 1905, Rec. Egypt. School Trop. Med., Cairo, iii, 78.

2. Brachyclonus Railliet \& Henry, 1910.

Anterior end bent dorsally. Month-opening guarded by a pair of ventral cutting-plates. Buccal capsule large, cupshaped. At its base a pair of strong ventral lancets, a pair of subdorsal lancets and a strongly-cleveloped dorsal cone projecting into the lumen and carrying the dorsal gutter. Bursa entire and elongate. The lateral and ventral rays arise from a much-elongated common trunk, the anterolateral ray being very widely separated from the remaining lateral rays. Externo-dorsal rays stout, arising about midway along the median stem of the dorsal ray. The latter is cleft for about one-sixth of its length, and its terminations are tricligitate, i.e. there are two pairs of accessory branches. Spicules slender, not barbed. Vulva in anterior half of body. Uterine branches opposed.

Hab. Small intestine of Tapir (Tapirus indicus). (One species known).

Genotype: B. indicus Railliet \& Henry, 1910.

Railliet \& Henry, 1910, Bull. Soc. Path. exot., Paris, iii, 312; Khalil, 1922, Ann. Mag. Nat. Hist., (9) x, 235.

\section{Globocephalus Molin, 1861.}

Syn. Cystocephalus Railliet, 1895; Characostomum Railliet, 1902; Crassisoma Alcssandrini, 1909; Raillietostrongylus Lane, 1923.

Stout forms without leaf-crowns or cutting-plates at the anterior margin of the buccal capsule. Buccal capsule deep, infundibular or subglobular, supported anteriorly by an external chitinoid ring. Mouth-opening tilted dorsally. There may or may not be a pair of teeth at the base of the buccal capsule. Dorsal gutter projects almost to the mouthopening. Dorsal ray cleft for less than one-sixth of its length, its terminations tridigitate. Spicules slender, curved dorsally at their tips or bent into an S-shape. An elongate accessory piece present. Vulva in posterior half of body. Uterine branches opposed.

Hab. Alimentary tract of Pigs and Monkeys.

Genotype: $G$. longemucronatus Molin, 1861. 
Molin, 1861, Mem. R. Ist. Veneto, ix, 436, 534; Raillict, 1902, Compt. rend. Soc. Biol., Paris, liv, 109; Alessandrini, 1909, Arch. Parasitol., Paris, xiii, 459 ; Lane, 1923, Parasitol., xv, 358; Cameron, 1924, Journ. Helminthol., ii, 65.

We have placed this genus in the subfamily Neeatorinae on account of its general resemblanees to the other members of that group. Although the ventral eutting-plates charaeteristic of the group are apparently absent, the general structure of the buecal eapsule and the form of the bursal rays suggest its inchusion here.

\section{Bunostomum Railliet, 1902 .}

Syn. Monodontus Molin, 1861, e.p. (= Monodontus Ransom, 1911, Cameron, 1923); Bustomum Lane, 1917.

Anterior end bent dorsally. Mouth guarded by a pair of ventral eutting-plates. Buceal capsule large, infundibular. Towards its base a strong dorsal tooth along which runs the dorsal gutter, and two or four smaller ventral lancets. Bursa with an asymmetrical dorsal lobe. The right externo-dorsal ray arises high up on the main dorsal stem, and is long and slender. The left externo-dorsal ray is much shorter, arising at about the level of the bifureation of the dorsal ray. Terminations of dorsal ray tridigitate. Spicules slender, not barbed. Vulva a little in front of the middle of the body. Uterine branches opposed.

Hab. Small intestine of Ruminants.

Genotype: B. [Strongylus] trigonocephalum (Rudolphi, 1808).

Rudolphi, 1808, Entozoorum . . Historia naturalis, i, Pl. II, figs. 5-6; Molin, 1861, Mem. R. Ist. Veneto, ix, 435, 463; Railliet, 1902, Compt. rend. Soc. Biol., Paris, liv, 108; 1910, Bull. Soc. Path. exot., Paris, iii, 312; Ransom, 1911, U.S. Dept. Agric., Bur. Anim. Indust. Bull. 127, 27, 124; Lane, 1917, Ind. Journ. Med. Res., iv, 414; Cameron, 1923, Journ. Helminthol., i, 99.

Railliet (1902) proposed the genus Bunostomum, with $B$. trigonocephalum as type, to replace Monodontus Molin, 1861, on account of the existence of earlier, very similar, generie names. There may be no justifieation for Railliet's proposal, but, as Ransom (1911) pointed out, if it is shown that $M$. semicircularis Molin, 1861, and $M$. trigonocephalus are not congenerie, then the genus Bunostomum, with the latter species as its type, must be retained. The two species mentioned are certainly not eongeneric, and therefore the genus Bunostomum stands.

Cameron (1923) considers that the statement of Railliet (1895) that Molin had made $B$. trigonocephalum the type of 
Monodontus amounts to a designation by Railliet himself of $B$. trigonocephalum as the type of that genus, and rejects Stiles \& Hassall's (1905) designation of $M$. semicircularis as type. There seems to be no justifieation for this conclusion. Railliet's statement that Molin had designated trigonocephalum as type was merely incorrect, and cannot be taken as a definite designation on his own part.

\section{Monodontus Molin, 1861.}

Syn. Eumonodontus Railliet, 1910, Cameron, 1923.

(For discussion of nomenclature, vide Bunostomum, supra).

Body stout, fusiform. Head bent slightly dorsally. A mouth-collar, raised into a ventral and two lateral lobes, apparently present. Buecal capsule cup-shaped, containing a small, prominent, dorsal tooth (eone?). Cervical papillae spine-like. Bursa very large, entire, with small, symmetrical dorsal lobe. Genital cone well developed. Externo-dorsal rays symmetrical. Terminal branches of dorsal ray bidigitate. Spicules alate and transversely striated, apparently fused distally and with a spatulate termination. Vulva a little behind the middle of the body. Uterine branches opposed.

Hab. Small intestine of Peccary (one species known).

Genotype: M. semicircularis Molin, 1861.

Molin, 1861, Mem. R. Ist. Veneto, ix, 469; Railliet, 1910, Bull. Soc. Path. exot., Paris, iii, 314.

This genus is imperfectly known, but is apparently quite distinct from Bunostomum. It bears a much eloser resemblance to Necator, and may even be synonymous with that genus.

\section{Gaigeria Railliet \& Henry, 1910.}

Buccal eapsule large, cup-shaped. At its base a freelyprojecting dorsal cone carrying the dorsal gutter, and a pair of ventral lancets. Bursa with a large dorsal lobe and two much smaller lateral lobes which are joined together ventrally. Antero-lateral ray widely separated from the remaining lateral rays. Externo-dorsal rays leave the main trunk of the dorsal ray in front of its bifurcation. Dorsal ray cleft for about a quarter of its length. Its terminal branches are tridigitate. Spicules slender, recurved distally, not barbed. Vulva just in front of the middle of the body.

Hab. Alimentary traet of Ruminants.

Genotype: G. pachyscelis Railliet \& Henry, 1910.

Railliet \& Henry, 1910, Bull. Soc. Path. exot., Paris, iii, 313; Cameron, 1924, Journ. Helminthol., ii, 41. 


\section{Uncinaria Frölich, 1789.}

Syn. Dochmius Dujardin, 1845; Dochmoides Cameron, 1924.

Mouth guarded by ventral cutting-plates. Buceal eapsule large, infundibular." Two subventral teeth present towards its base. Dorsal cone within the wall of the capsule, its tip not projecting into the lumen. Antero-lateral ray of bursa rather divergent from the remaining lateral rays. Externodorsal rays arise almost at the root of the median dorsal stem. Dorsal ray cleft for almost half its length; its terminations tridigitate. Spicules slender, not barbed. Vulva at about the posterior third of the body.

Hab. Intestine of Mammals.

Genotype: U. [Ascaris] criniformis (Goeze, 1782).

Goeze, 1782, Naturg. d. Eingeweidewïmer, Blankenburg, 106 ; Frölich, 1789, Nuturforscher, Halle, xxiv, 136; Schneider, 1866, Monograplie der Nematoden, Berlin, 139; Looss, 1905, Rec. Egypt. School Trop. Med., Cairo, iii, 2s; Hall, 1916, Proc. U.S. Nat. Mus., 1, 108.

Cameron (1924, Journ. Helminthol., ii, 46) has proposed the generic name Dochmoides to replace Uncinaria, on the ground that the type of the latter genus, $U$. vulpis (designated by Stiles \& Hassall, 1899, Rep. Fur Seal Invest., Washington, Pt. 3, 164), is a species inquirenda. Looss (1902, Centralbl. f. Balit., (I), xxxi, 423) has pointed out that Frölich indicated plainly that he regarded $A$. criniformis Goeze, 1782, as the more important species of his genus Uncinaria, and he considers it, therefore, to be the type. Since Stiles (1902) has suggested that $U$. vulpis is in all probability a synonym of $U$. criniformis, it seems reasonable to follow Looss in regarding $U$. criniformis as the genotype. $U$. criniformis may be identified by comparison of specimens collected from the type host with the deseription and figure of Schneicler (1866), who re-examined the original material.

\section{Tetragomphius Baylis \& Daubney, 1923.}

Mouth guarded by poorly-developed rentral eutting-plates. Buceal capsule eup-shaped. At its base a pair of subdorsal and a pair of subventral lancets, the former bicuspid and the latter usually tricuspicl. Dorsal cone represented by a blunt tuberele carrying the dorsal gutter. Bursa short and stunted. Dorsal ray eleft almost to point of origin of externo-dorsal rays, its terminations bidigitate. Spicules extremely long, filiform, not barber. Vulva in posterior half of body.

Hab. Stomach of Raccoon (one speeies known).

Genotype: T. procyonis Baylis \& Daubney, 1923. 
Baylis \& Daubney, 1923, Ann. Mag. Nat. Hist., (9) xi, 334; 1923, Rec. Ind. Mus., xxv, 573.

\section{Acheilostoma Leiper, 1911.}

Mouth-opening slightly tilted dorsally. Buccal capsule fairly large, subglobular. At its base a dorsal cone, which may carry also two smaller lateral lancets, and two pairs of subventral lancets. Antero-lateral ray of bursa divergent from the remaining lateral rays, which are closely applied to each other. Externo-dorsal rays spring from median stem of dorsal ray. Dorsal ray cleft for at least two-thirds of its length ; its terminations bidigitate. Spicules long and filiform. No accessory picce. Vulva near middle of body.

Hab. Intestine and gall-bladder of Rodents.

Genotype: A. simpsoni Leiper, 1911.

Leiper, 1911, Proc. Zool. Soc., London, 549; Railliet, 191S, Bull. Soc. Path. exot., Paris, xi, 97.

\section{Grammocephalus Railliet \& Henry, 1910.}

Buccal capsule wide anteriorly and narrowed posteriorly, the narrowing being more abrupt on the dorsal wall and accompanied by an infolding of the capsule. Towards the base of the capsule a pair of lateral and a pair of subventral teeth, also a dorsal cone carrying the dorsal gutter. Intestine with a long, anteriorly-directed dorsal caecum arising close to its union with the oesophagus. Externo-dorsal rays of bursa spring from median stem of dorsal ray just in front of its division. Terminations of dorsal ray bidigitate. Spicules stout, alate. Vulva close to the middle of the body.

Hab. Bile-ducts of Elephants.

Genotype: G. [Sclerostoma] clathratus (Baird, 1S68).

Baird, 1868, Proc. Zool. Soc., London, 262 ; Railliet \& Henry, 1910, Bull. Soc. Path. exot., Paris, iii, 313; Lane, 1921, Ind. Journ. Med. Res., ix, 163.

\section{Bathmostomum Railliet \& Henry, 1909.}

Buccal capsule fissured on its dorsal and lateral aspects. Its internal surface raised, chicfly ventrally and laterally, into shelf-like projections encroaching on the oral cavity. A small dorsal tooth surmounts the dorsal column of the oesophagus. Externo-dorsal rays of bursa spring from the branches of the dorsal ray. The latter is cleft for almost the whole of its length. Spicules stout. Vulva near the middle of the body.

Hab. Caecum of Elephants (one species known).

Genotype: B. [Dochmius] sangeri (Cobbold, 1879). 
Cobbold, 1879, Parasites, London, 393, 399; Railliet \& Henry, 1909, Compt. rend. Soc. Biol., Paris, lxvi, 170; Lane, 1921, Ind. Journ. Hed. Res., ix, 163; Khalil, 1922, Proc. Zool. Soc., London, 275.

\section{Fam. 3. DIAPHANOCEPHALIDAE Travassos, 1919.}

Head laterally compressed. A rudimentary leaf-erown may be present or absent. Mouth-opening a dorso-ventral slit, facing anteriorly or more or less inclined towards the dorsal side. Walls of buccal capsule valve-like, supported by six external longitudinal parenchymatous bands which terminate as cephalic papillae, and by one or two transverse internal ridges. A dorsal and a ventral cuticular pad present towards the base of the buccal capsule. Oviparous. Parasitie in the alimentary tract of Reptiles.

\section{Diaphanocephalus Diesing, 1851.}

Head slightly eonstricted off from body. Margin of mouth shows signs of differentiation into a leaf-crown. Valves of buccal capsule supported by two transverse internal chitinoid ridges, of which the posterior is V-shaped dorsally and ventrally. A pair of delicate chitinoid flanges project into the buccal capsule from the ventral cuticular pad. There is a dorsal hump in front of the bursa of the male. Bursa short, entire. Genital cone very long, with the cloacal opening on its ventral surface some distance from its tip.

Hab. Alimentary tract of Lizards and (?) Snakes.

Genotype: D. [Strongylus] galeatus (Rudolphi, 1819).

Rudolphi, 1819, Entozoorum Synopsis, 648; Diesing, 1851, Systema Helminthum, ii, 82, 297; Molin, 1861, Mem. R. Ist. Veneto, ix, 578; Raillict \& Henry, 1909, Compt. rend. Soc. Biol., Paris, lxvi, 171; Baylis and Daubney, 1922, Mem. Ind. Mus., vii, 331; Daubncy, 1923, Parasitol., xv, 67; Ortlepp, 1923, Journ. Helminthol, i, 165.

\section{Kalicephalus Molin, 1861.}

Syn. Occipitodontus Ortlepp, 1923.

A rudimentary leaf-crown may be present or absent. Valves of buccal capsule supported by a single internal transverse chitinoid ridge, which is $\mathrm{V}$-shaped dorsally and ventrally. Oesophageal funnel may contain three small teeth. There is no dorsal hump in front of the bursa of the male. Bursa well developed. Genital cone relatively small, not protruding beyond the margin of the bursa. An aecessory pieec may be present or absent. Vulva in posterior half of body. Uterine branehes opposed or parallel. 
Hab. Alimentary tract of Snakes and Lizards.

Genotype: $K$. mucronatus Molin, 1861.

Molin, 1861, Mem. R. Ist. Veneto, ix, 436, 538; Baylis and Daubney, 1922, Mem. Ind. Mus., vii, 331 ; Daubney, 1923, Parasitol., xv, 67; Ortlepp, 1923, Journ. Helminthol., i, 165.

Ortlepp (1923) proposed the genus Occipitodontus for 0 . fimbriatus (= Kalicephalus willeyi v. Linstow, 1908, Baylis and Daubney, 1922, Daubney, 1923), on account of the presence in this form of a rudimentary leaf-crown at the entrance to the mouth and the occurrence of three small teeth in the oesophageal funnel. Indications of a leaf-crown are present in other species of Kalicephalus, and we do not consider the other character mentioned of sufficient importance to warrant the separation of a species agreeing so closely in all other characters with the remaining members of the genus Kalicephalus. A similar position, as regards the occasional presence of teeth in some of the members of a genus, is found in the genera Oesophagostomum and Globocephalus.

\section{Fam. 4. METASTRONGYLIDAE Leiper, 1908.}

Buccal capsule much reduced or absent. Bursa of male may be relatively well developed or vestigial, with a corresponding degree of development of the bursal rays. Parasites of the respiratory and circulatory systems, and of the cranial sinuses, of Vertebrates.

\section{Metastrongylus Molin, 1861.}

Mouth with six "lips," of which the two lateral are the largest. Bursa small, with its greatest diameter anteroposteriorly. The wall of the bursa is thickened in its posterior half. All the bursal rays are very stout, except the dorsal and externo-dorsal. The tip of the antero-lateral ray bears a large, lobulate swelling. Spicules long, terminating in simple hooks. Tail of female recurved ventrally. Vulva immediately in front of anus. Uterine branches parallel. Eggs contain embryos when laid.

Hab. Respiratory passages of Suidae and (accidentally) of Man and Ruminants.

Genotype: M. [Strongylus] elongatus (Dujardin, 1845).

Dujardin, 1845, Histoire nat. des Helminthes, Paris, 127 ; Molin, 1861, Mem. R. Ist. Veneto, ix, 437, 588; Railliet \& Henry, 1907, Compt.rend. Soc. Biol., Paris, lxiii, 751; 1911, Bull. Soc. Path. exot., Paris, iv, 695; Gedoelst, 1923, Bull. Soc. Path. cxot., Paris, xvi, 622. 
2. Choerostrongylus Gedoelst, 1923.

Mouth-struetures as in Metastrongylus. Bursa voluminous, with its greatest dimension at right angles to the long axis of the body. Wall of bursa not thickened in its distal part. The tip of the antero-lateral ray not swollen. Spicules long, terminating in double hooks. Tail of female straight, with a rentral cuticular dilatation covering the vulva and anus.

Hab. Respiratory passages of Suidae.

Genotype: C. [Metastrongylus] pudendotectus (Wostokow, 1905) $(=11$. brevivaginatus Railliet \& Henry, 1907).

Wostokow, 1905, Rec. Trav. Inst. T'et. Charkow, vii, 2 (not verified); Railliet \& Henry, 1907, Compt. rend. Soc. Biol., Paris, lxiii, 751 ; Gedoelst, 1923, Bull. Soc. Path. exot., Paris, xvi, 622; Skrjabin, 1924, Compt. rend. Soc. Biol., Paris, xe, 1215.

\section{Dictyocaulus Railliet \& Henry, 1907.}

A rery short and small buceal eapsule present, with a ehitinoid ring at its base. Bursa of male short. Mediolateral and postero-lateral rays fused throughout the greater part of their length. Terminations of dorsal ray bidigitate or tridigitate. Spicules short and stout, simple in strueture. An accessory piece present. Vulva near the middle of the body. Uterine branches opposed. Eggs eontain embryos when laid, and may be without shells.

Hab. Bronchi of herbivorous Mammals.

Genotype: D. [Strongylus] filaria (Rudolphi, 1S09).

Rudolphi, 1809, Entozoorum Historia naturatis, ii, 219; Raillict \& Henry, 1907, Compt. rend. Soc. Biol., Paris, lxiii, 752 ; Neveu-Lemaire, 1918, Mém. Soc. Zool. France, xxvii, 5.

4. Synthetocaulus Railliet \& Henry, 1907.

Extremely slender forms. Posterior end of male reinforeed with a chitinoid are. Bursa short. Medio-lateral and posterolateral rays parallel and close together. Dorsal ray a thick trunk with short terminal digitafions. Spicules fairly stont, simple in structure or divided into two processes distally. An accessory pieee present. A "telamon" also present. Vulva near anus. Uterine branches parallel. Eggs unsegmented when laid. Larva with an nndulating terminal caudal process and a subterminal caudal spine.

Hab. Finer bronchioles and connective tissue of lungs of Mammals.

Genotype: S. [Strongylus] commutatus (Diesing, 1851).

Diesing, 1851, Systema Helminthum, ii, 315; Railliet \& Henry, 1907, Compt. rend. Soc. Biol., Paris, lxiii, 752; Hall, 1916, Proc. U.S. Nat. Mus., l, 163. 


\section{Haemostrongylus Railliet \& Henry, 1907.}

Syn. ? Haemaiozoon Leisering, 1865.

Small but relatively stout forms. Ventral rays of bursa of male fused except at their tips. Autcro-lateral rays somewhat shorter than, and divergent from, the remaining lateral rays, which are fused proximally. Median stem of dorsal ray stout and relatively elongate; its terminal branches very short. Externo-dorsal rays originate separately from the dorsal ray and are short. Spicules long and slender. Accessory piece absent. Vulva in posterior half of borly. Oviparous or viviparous. Embryos with an undulating caudal process, and at the anterior extremity a small ventral button.

Hab. Circulatory and respiratory systems of Carnivores.

Genotype: H. [Strongylus] vasorum (Baillet, 1S66).

Baillet, 1866, Hist. nat. des Helminthes des principaux Mamm. domestiques, Paris, 69; Railliet \& Henry, 1907, Compt. rend. Soc. Biol., Paris, lxiii, 753; 1913, Bull. Soc. Path. exot., Paris, vi, 451.

\section{Troglostrongylus Vevers, 1923.}

Antero-lateral and medio-lateral rays of bursa fused to form one large ray. Postero-lateral and externo-dorsal rays separate and of about the same size. Dorsal ray single and thick. Spicules long, tessellated and with pectinate lamellae along their inner edges. Each spicule ends in a palmate expansion, the fingers of which are webbed with cuticular material bearing spines. Vulva just behind the middle of the body. Ovoviviparous.

Hab. Frontal sinus of Tiger (one species known).

Genotype: T. troglosirongylus Vevers, 1923.

Vevers, 1923, Proc. Zool. Soc., London (1922), 906.

\section{Crenosoma Molin, 1861.}

Cuticle, at least towards the anterior end, bearing rings of minute spines. Bursa consists of two large lateral lobes and a dorsal lobe. Antero-lateral ray arises separately from the remaining lateral rays. Externo-dorsal ray arises separately from the dorsal, which is undivided except at its tip. Spicules long. An accessory piece present. Vulva towards the middle of the body. Viviparous.

Hab. Respiratory tract of Carnivores and Insectivores.

Genotype: C. [Strongylus] striatum (Zeder, 1800).

Zeder, 1800, Naturg. der Eingeweidewürmer, Leipzig, 74; Molin, 1S61, Mem. R. Ist. Veneto, ix, 435, 437; Eberth, 1S63, Unters. iiber Nematoden, Leipzig, Pls. viii, ix; Stossich, 1896, Boll. Soc. Adriat. Sci. nat., Trieste, xvii, 125; Railliet \& Henry, 1909, Compt. rend. Soc. Biol., Paris, lxvi, 86. 


\section{Pseudalius Dujardin, 1845.}

Bursa reduced to two elongate lateral lobes projeeting ventrally almost at right angles to the longitudinal axis of the body, and containing each a lateral ray bearing on its inner surface two papillary terminations, one near the extremity and one near the base. These lobes are joined dorsally by a flange of cuticle in the middle of which there is a slight indication of a clorsal lobe. Spieules short, membranous, folded, not fused at their tips. Posterior end of female bent dorsally in front of the vulva. Vulva just in front of the anus, at the extremity of a tubular outgrowth. Viviparous.

Hab. Respiratory and circulatory systems of Porpoise (one speeies known).

Genotype: P. [Strongylus] inflexus (Rudolphi, 1809).

Rudolphi, 1809, Entozoorum Hist. nat., ii, 227; Dujardin, 1845, Hist. nat. des Helminthes, Paris, 135; Baylis \& Daubney, 1925, Parasitol., xvii, 202.

\section{Stenurus Dujardin, 1845.}

\section{Syn. Pharurus Leuckart, 1848; Prosthecosacter Diesing, 1851 .}

A shallow buceal capsule present. Bursa fairly well developed, more or less divided into a dorsal lobe and a pair of lateral lobes. Each of the latter eontains a lateral and a ventral ray, the former with a trilobed extremity and a single papillary termination on its inner surfaee, the latter also with a single termination. Dorsal ray relatively elongate, with a pair of ventral terminations near its tip. Spicules typically broad, membranous, folded and apparently fused at their tips. A flattened, tongue-shaped accessory piece present. Tail of female with a small terminal proeess or button, situated dorsally. Anus subterminal. Vulva just in front of anus, with a euticular proeess or swelling on its anterior lip. Viviparous.

Hab. Tympanic cavity, blood-sinusus of head, and respiratory passages of Cetaeca.

Genotype: S. [Strongylus] minor (Kuhn, 1S29).

Knhn, 1830 [1829], Mém. Mus. Hist. nat., Paris, xviii, 363; Dujardin, 1845, Hist. nat. des Helminthes, Paris, 266; Schneider, 1S66, Monographie der Nematoden, Berlin, 174; Baylis \& Daubney, 1925, Parasitol., xvii, 204.

\section{Filaroides van Beneden, 1858.}

A very shallow buceal eapsule present, with slightly thickened walls. Thail of male bears two subventral, kidney-shaped swellings, each with five papillae (of which two are lateral and 
three ventral), and ends in a short spike. Anus of female has apparently a swollen border. Vulva somewhat behind the middle of the body. Uterine branches parallel. Viviparous.

Hab. Respiratory passages of Mustelidae (probably one species known).

Genotype: $F$. [Ascaris] bronchialis (Gmelin, 1790) $(=F$. mustelarum van Beneden, 1858).

Gmclin, 1790, Systema Naturae, 13th ed., 3031; van Beneden, 1858, Mém. sur les Vers intestinaux, Paris, 267; 1S61, Compt. rend. Acad. Sci., Paris, ii, 267; v. Linstow, 1873, Arch.f. Naturg., xxxix, 300; and 1874, xl, 135.

\section{Fam. 5. TRICHOSTRONGYLIDAE Leiper, 1912.}

Buceal eapsule rudimentary or absent. Bursa of male with well-developed lateral lobes. Dorsal lobe small or ill-defined. Parasites of the alimentary tract of Vertebrates.

\section{Subfam. 1. TRICHOSTRONGYLINAE Leiper, 1908.}

More or less slender forms. Buccal capsule absent or rudimentary and ill defined. Vulva towards the posterior end of the body. Female genital tubes paired.

\section{Trichostrongylus Looss, 1905.}

\section{Syn. Libyostrongylus Lane, 1923.}

Cuticle of anterior end may be raised into swellings. Cervieal papillae absent. Buceal eavity ill defined. Bursa with large lateral lobes but without well-developed dorsal lobe. Ventral rays widely separated and of very different thicknesses; the ventro-ventral thin and ventrally directed, the latero-ventral thick, divergent from the ventro-ventral and close to the lateral rays. Postero-lateral ray thinner than, and divergent from, the remaining lateral rays, lying close to the extermo-dorsal ray. Dorsal ray cleft near its tip, ending in short digitations. Prebursal papillae present. Spicules short, spoon- or spatula-shaped, appearing twisted on account of ridges on their surfaces. An accessory piece present. Vulva typically with protruding lips. Eggs thinshelled, segmenting when deposited.

Hab. Alimentary tract of Herbivores, Rodents, Birds and, more rarely, Man.

Genotype : T. [Strongylus] retortaeformis (Zeder, 1800).

Zeder, 1800, Naturg. der Eingeweidewiirmer, 73; Looss, 1905, Centralbl. f. Bakt., (I), xxxix, 409; Travassos, 1914, Brazil Medico, Rio de Janeiro, xxviii, 325; Hall, 1916, Proc. U.S. Nat. Mus., 1, 123; Lane, 1923, Parasitol., xv, 348. 


\section{Cooperia Ransom, 1907.}

Cuticle of anterior end frequently dilated. Cutiele of body marked with fourteen to sixteen longitudinal lines or ridges. Cervical papillae absent. Mouth-cavity small, indefinite. Bursa with two lateral lobes and a small dorsal lobe. Lateroventral ray rather widely separated from, and eonsiderably thieker than, ventro-ventral ray, but eurving distally in the same direetion. Postero-lateral ray slender. Externo-dorsal rays long, arising high up on main dorsal stem. Dorsal ray eleft for from one-third to one-half of its length; its main branches parallel or enrved to form a lyre or horseshoe. From each of the main branches, usually near its origin, a short braneh extends ventrally into a vesicular swelling on the imer surface of the bursa. Prebursal papillae absent. Spicules short, foliaceous. Aecessory piece absent.

Hab. Alimentary tract of Mammals.

Genotype: C. [Strongylus] curlicei (Giles, 1892).

Giles, 1892, Sci. Mem. Med. Off. Army, India, Calentta, Pt. 7, 49 ; Railliet, 1393, Traité de Zool. méd. et agric., 2nd ed., Paris, 442; Ransom, 1907, U.S. Dept. Agric., Bur. Anim. Indust. Circular 116, 3; 1911, U.S. Dept. Agric., Bur. Anim. Indust. Bull. 127, 69.

\section{Travassosius Khalil, 1922.}

Cutiele longitudinally striated except at the head, where it is transversely striated. Cervical papillae prominent. Buecal cavity not well defined. Bursa with large lateral lobes, but without well-developed dorsal lobe. Ventral rays widely separated and of very different thicknesses. Ventroventral ray thin and direeted ventrally; latero-rentral thick and in elose relation to the lateral rays. Dorsal ray long, slender, and eleft at its tip, each branch ending in two digitations. Prebursal papillae long and eonspienons. Spienles short, twisted, with knob-like terminations. Aceessory pieee absent. Eggs seginenting when deposited.

Hab. Stomach of Beaver.

Genotype: T. rufus Khalil, 1922.

Khalil, 1922, Ann. Mag. Nat. Hist., (9) x, 288.

4. Graphidium Railliet \& Henry, 1909.

Cuticle with prominent longitudinal striations. Cervical papillae present. Mouth large, limited by a chitinoid buceal ring. Bursa with large lateral lobes, but without a welldefineal dorsal lobe. Iatero-ventral ray larger than ventroventral ray, but running nearly parallel to it. Externo- 
dorsal rays long and prominent, arising ligh up on the median dorsal stem and reaching margin of bursa. Dorsal ray relativcly long, bifurcate at its tip, eaeh branch again bifurcate. Prebursal papillae present. Spicules long, slender, and branched at their tips to form multiple terminations. An accessory piece present. Vulva sometimes eovered by a euticular process. The body narrows abruptly behind the vulva.

Hab. Alimentary tract of Rodents.

Genotype: G. [Strongylus] strigosum (Dujardin, 1845).

Dujardin, 1845, Hist. nat. des Helminthes, Paris, 120; Railliet \& Henry, 1909, Compt. rend. Soc. Biol., Paris, lxvi, 86; Hall, 1916, Proc. U.S. Nat. Mus., 1, 123, 139; Travassos, 1921, Mem. Inst. Oswaldo Cruz, Rio de Janeiro, xiii, 70; Cameron, 1923, Journ. Helminthol., i, 71.

\section{Graphidioides Cameron, 1923.}

Cuticle with prominent longitudinal striations. Cervical papillae absent. Bursa with large lateral lobes, joined by a small, ill-defined dorsal lobe. Latero-ventral ray much longer and thicker than, and widely divergent from, ventroventral ray. Externo-dorsal rays originate high up on the median dorsal stem, but do not reach the margin of the bursa. Dorsal ray long and slender, eleft near its tip, eaeh branch ending in three short digitations. Prebursal papillae present. Spicules long and filiform, eaeh consisting of two chitinized rods joined at the distal extremity, which is simple. Each spieule possesses a median membranous expansion, and the membranes join eaeh other near the tips of the spicules. An aecessory piece present.

Hab. Stomach of Rodents.

Genotype: G. [Strongylus] affinis (Mégnin, 1895).

Mégnin, 1895, Bull. Soc. Zool. France, xx, 173; Travassos, 1921, Mem. Inst. Oswaldo Cruz, Rio de Janeiro, xiii, 71; Cameron, 1923, Journ. Helminthol., i, 71.

\section{Obeliscoides Graybill, 1924.}

Syn. Obeliscus Graybill, 1923, nec Humplireys, 1797.

Cutiele with a number of longitudinal striations. Cervical papillae present. Bursa with large lateral lobes and a small, but well-defined, dorsal lobe. Ventral rays, after a pronouneed divergence, terminate near each other. The rentrorentral ray is small, while the latero-ventral is the thiekest and longest of all the rays. Antero-lateral ray long and stont, the remaining lateral rays and the externo-dorsal slender and considerably shorter. Dorsal ray short, with a pair of short 
accessory branches and bidigitate terminations. Prebursal papillae present. Spicules slender, bifid distally, each branch ending in a barl), one branch more or less enfolding the other laterally and ventrally. Accessory piece apparently absent. Eggs segmenting when deposited.

Hab. Alimentary traet of Rabbit (one speeies known).

Genotype: O. [Obeliscus] cuniculi (Graybill, 1923).

Graybill, 1923, Parasitol., xv, 340; and 1924, xvi, 317.

7. Hyostrongylus Hall, 1921.

Cervical papillae present. Bursa with well-developed lateral lobes and a small, distinet dorsal lobe. Latero-ventral ray larger than ventro-ventral ray, its tip turning ventrally towards that ray. Postero-lateral ray rather wickely divergent from the remaining lateral rays. Externo-rorsal rays well developed. Dorsal ray fairly long, bifurcate at its tip, and having a pair of small accessory branches at about one-third of its length from the tip. Probursal papillae present. Spicules with bifid terminations. An accessory picee and a "telamon" present. Eggs segmenting when deposited.

Hab. Stomach of Suidae.

Genotype: II. [Strongylus] rubidus (Hassall \& Stiles, 1892).

Hassall \& Stiles, 1892, Journ. Comp. Med. Vet. Arch., New York, xiii, 207; Hall, 1921, Proc. U.S. Nat. Mus., lix, 543.

\section{Ostertagia Ransom, 1907.}

Cuticle marked with twenty-five to thirty longitudinal ridges. Cuticle of head may be slightly dilated. Cervical papillac present. Mouth-cavity small. Bursa with two lateral lobes and a smaller dorsal lobe. Ventral rays elose together. parallel. Dorsal ray with two main branches, each giving off one or two short accessory branches. Attached to the posterior end of the male, towards the dorsal side and within the bursa, is an accessory bursal membrane, with a free posterior edge, and supported by two slender, divergent rays. Prebursal papillae present. Spicules short, divided distally into two or three terminal processes. An accessory piece may be present or absent. Vulva naked or covered by a fiap.

Hab. Stomach of Ruminants and Opossums.

Genotype: O. [Strongylus] ostertagi (Stiles, 1892).

Stiles, 1892, Journ. Comp. Med. Vet. Arch., New York, xiii, 147; Ransom, 1907, U.S. Dept. Agric., Bur. Anim. Indust. Circular 116, 2; 1911, U.S. Dept. Agric., Bur. Anim. Indust. Bull. 127, 55; Travassos, 1921, Mem. Inst. Oswaldo Cruz, Rio de Janeiro, xiii, 56. 


\section{Ornithostrongylus Travassos, 1914.}

Syn. Cephalostrongylus Irwin-Smith, 1920.

Cuticle of anterior end inflated. Buccal cavity with indieations of chitinoid structure. Ventro-ventral and lateroventral rays of bursa equal in thickness and close to each other. Postero-lateral ray about as thick as, but divergent from, the renaining lateral rays. Dorsal ray cleft for a varying distance, up to half its total length; each branch ending in three or four digitations. Prebursal papillae present. Spicules short, ending in three points. A "telamon" present. Accessory piece apparently absent. Eggs segmenting or containing embryos when deposited.

Hab. Small intestine of Birds.

Genotype : O. fariai Travassos, 1914.

Travassos, 1914, Brazil Medico, Rio de Janeiro, xxviii, No. 17 ; 1921, Mem. Inst. Oswaldo Cruz, Rio de Janciro, xiii, 1 ; Irwin-Smith, 1920, Proc. Linn. Soc. N.S.W., Sydney, xlv, 553.

\section{Trichohelix Ortlepp, 1922.}

Body spirally coiled. Cuticle of anterior end inflated, the inflation limited behind by a deep constriction encircling the neck. Cuticle of the rest of the body markedly inflated and showing transverse striations only on the ventral surface of the anterior half of the body. Longitudinal striations faint. Cervical papillae absent. Bursa indistinetly trilobate. Ventro-ventral ray curved ventrally at its tip, diverging from latero-ventral ray. Antero-lateral ray rather divergent from the remaining lateral rays. Tip of medio-lateral ray sharply recurved inwards. Externo-dorsal rays relatively short and stout, originating from the median stem of the dorsal ray near its base. Dorsal ray stout, eleft for about one-third of its length, with tridigitate terminations. Prebursal papillae absent. Spicules tubular, bifid distally. An accessory piece present. Vulva slightly in front of anus. Eggs segmenting when deposited.

Hab. Intestine of Armadillos (one species known).

Genotype : T. [Oesophagostomum] tuberculata (Parona and Stossich, 1901).

Parona and Stossich, 1901, Boll. Mus. Zool. Anat. Comp., Genova (110), 1; 1902, Atti Soc. Ligust. Sci. nat., Genova, xiii, 7; Ortlepp, 1922, Ann. Mag. Nat. Hist., (9) ix, 413.

\section{Oswaldocruzia Travassos, 1917.}

Cuticle of anterior end inflated and transversely striated. Ventral rays of bursa elose together and equal in size. Anterolateral ray divergent from the remaining lateral rays, not 
very dissimilar in size. Externo-dorsal rays about as long as the lateral rays. Dorsal ray long, fairly stout, eleft at its tip, with two pairs of small aecessory branehes and a number of short terminal digitations. Spieules distinetly bifureate, but of complex strueture, with multiple terminations. Acees sory piece absent. Eggs contain embryos when deposited.

Hab. Intestine and lungs of Reptiles and Batrachians.

Genotype: O. [Strongylus] subauricularis (Rudolphi, 1819).

Rudolphi, 1819, Entozoorum Synopsis, 649; Travassos, 1917, Brazil Mcdico, Rio de Janeiro, xxxi, 73; 1921, Mem. Inst. Oswaldo Cruz, Rio de Janeiro, xiii, 53.

\section{Molineus Cameron, 1923.}

Cuticle of anterior end inflated and transversely striated. Cervical papillae absent. Bursa not distinetly divided into lobes. Ventral rays long and parallel, but slightly separated distally. Antero-lateral ray about half the length of the other lateral rays and somewhat divergent from them. Externo-dorsal rays considerably shorter than the posterolateral and medio-lateral rays, not reaching the margin of the bursa. Dorsal ray bifureate at its tip, each branch ending in three short digitations. Prebursal papillae absent. Spieules equal, with double points directed posteriorly. An aecessory pieee present. Eggs contain embryos when deposited.

Hab. Alimentary tract of Mammals (Felidae and Squirrelmonkeys).

Genotype: M. felineus Cameron, 1923.

Travassos, 1921, Mem. Inst. Oswaldo Cruz, Rio de Janeiro, xiii, 84; Philpot, 1922, Ann. Mag. Nat. Hist., (9) x, 242; Cameron, 1923, Journ. Helminthol., i, 71.

\section{Haemonchus Cobb, 1898.}

Syn. Abomesi Simmonds, 1881 (? 1882).

A small buceal eavity present, with a slender tooth or lancet originating from the clorsal part of its base. A pair of well-developed, spine-like eervieal papillae present. Bursa with large lateral lobes and a small, very asymmetrical dorsal lobe attaehed to one of the lateral lobes near its base. Ventral rays separate distally. Extemo-(lorsal rays very long and slender. Main trunk of dorsal ray originates with the left externo-dorsal ray in the left lateral lobe of the bursa, and is bifureate distally. Prebursal papillae present. Spieules relatively short, barbed at their tips. An aecessory piece present. Vulva eovered by a eutieular flap. Eggs segmenting when deposited. 
Hab. Stomach of Ruminants, doubtfully of Mouse and accidentally of Man.

Genotype: H. [Strongylus] contorius (Rudolphi, 1803).

Rudolphi, 1803, Arch.f. Zool. u. Zoot., Brunswick, iii, 15; Cobb, 1898, Agric. Gaz. N.S.IV., Sydney, ix, 447; Ransom, 1911, U.S. Dept. Agric., Bur. Anim. Indust. Bull. 127, 49.

\section{Nematodirus Ransom, 1907.}

Syn. ? Microcephalus Romanovitch, 1915.

Body markedly tapering and thread-like anteriorly. Anterior end with a slight vesicular swelling. Body with eighteen longitudinal lines. Cervical papillac absent. Dorsal lobe of bursa reduced to two small, short lobules, each supported by a separate ray. Ventral rays close together and parallel. Postero-lateral ray divergent distally from the other lateral rays. There is no mpaired median dorsal ray. Spicules slender, relatively long, united by a membrane, at least distally. Accessory piece absent. Tail of female truncate, usually with a terminal spike. Vulva typically in posterior region of borly. Eggs relatively large (generally over $150 \mu$ long).

Hab. Stomach and small intestine of Mammals, chicfly Herbivores.

Genotype: N. [Ascaris] filicollis (Rudolphi, 1802).

Rudolphi, 1802, Arch. f. Zool. u. Zoot., Brumswick, ii, 23; Ransom, 1907, U.S. Dept. Agric., Bur. Anim. Indust. Circular 116, 4; Railliet \& Henry, 1912, Bull. Soc. Path. exot., Paris, v, 36; May, 1920, Proc. U.S. Nat. Mus., lviii, 577.

We have included as a doubtful synonym of Nematodirus the genus Microcephalus Romanovitch, 1915 (Compt. rend. Soc. Biol., Paris, lxxviii, 451). This genus is insufficiently characterized. The only character at present available to distinguish it from Nematodirus is the position of the vulva, which is stated by the author to be at the junction of the anterior and second fourths of the body. It is significant that $M$. longissime spiculatus Romanovitch shares with Nematodirus the character, unique amongst the Trichostrongylidae, of having eggs over $150 \mu$ in length (in Romanovitch's species they are said to be $240 \mu$ long).

15. Mecistocirrus Railliet \& Henry, 1912.

Body markedly attenuated anteriorly. Antcrior end with a slight vesicular swelling. Cuticle of body with numerous inconspicuous longitudinal ridges. Cervical papillae conspicuous, spine-like. Mouth subterminal, slightly dorsal, with a large buccal lancet. Bursa divided into two lateral lobes and a small, but distinct, dorsal lobe. Ventro-ventral 
ray short, slender and widely divergent from the lateroventral. Latero-ventral and antero-lateral rays extremely stout, close together and parallel. The remaining rays are all slender. Dorsal ray short, bifureate terminally, with three pairs of papillary terminations. Prebursal papillae present. Spicules very long, slender and united for almost their whole length. Aecessory piece apparently absent. Vulva close to anus, prominent, with chitinoid lips. Vagina very long, anteriorly directed. Eggs of normal size, i.e. less than $150 \mu$ in length.

Hab. Stomach and small intestine of Ruminants, Pig and (doubtfully) Man.

Genotype: M. [Strongylus] digitatus (v. Linstow, 1906).

v. Linstow, 1906, Spolia Zeylanica, iii, 168; Railliet \& Henry, 1912, Bull. Soc. Path. exot., Paris, v, 38; NevellLemaire, 1914, Bull. Soc. Zool. France, xxxix, 293; Morishita, 1922, Annot. Zool. Japon., x, 89; Cameron, 1923, Journ. Helminthol., i, 71 .

\section{Histiostrongylus Molin, 1861.}

Cuticle of auterior end swollen and with a campanulate euticular collar, armed with large, simple or bifurcate, backwardly-direeted spines. Month small and cireular. Oesophagus short, club-shaped. Bursa with large lateral lobes and a small dorsal lobe. Ventral rays large, equal in size, slightly divergent from each other. Antero-lateral ray divergent from the other lateral rays, which have a common stem. Externo-dorsal ray markedly slsorter and more slender than the lateral rays. Dorsal ray with a pair of small lateral branches, and bifurcate at its tip. Spienles rather long, with slightly expanded terminations. An accessory piece present. Candal end of female with a slender terminal spike and two small subventral processes. Vulva behind the middle of the body. Uterine branches opposed. Eggs contain embryos when deposited.

\section{Hab. Alimentary tract of Bats.}

Genotype: H. coronatus Molin, 1861.

Molin, 1861, Mem. R. Ist. Veneto, ix, 611 ; Travassos, 191S, Rev. Soc. Braz. Sci., iii. 194; 1921, Mem. Inst. Oswaldo Cruz, Rio de Janeiro, xiii, 72; Bonlenger, 1926, Parasitol., xviii, 87.

Parts of this diagnosis, especially those parts relating to the arrangement of the bursal rays, are derived mainly from Boulenger (1926), who has pointed ont that the two speeies, $H$. tipula (van Beneden) and $H$. paradoxus Travassos, provisionally referred by Travassos (1918) to Histiostrongylus, are not congenerie with $H$. coronatus, and has proposed for them the name Anoplostrongylus. 


\section{Subfam. 2. HeligmosominaE Travassos, 1914.}

Slender forms. Buceal capsule absent or rudimentary. Vulva situated close to anus. Female genital tube single.

1. Heligmosomum Railliet \& Henry, 1909.

Usually minute forms, not spirally eoiled. Cuticle of normal thiekness, with prominent transverse striations and longitudinal markings, of which the dorsal and ventral may be very salient. Head with a euticular dilatation. Bursa of male large, trilobate. Ventral rays widely separated and divergent distally. Postero-lateral ray relatively long and divergent from the other lateral rays. Externo-dorsal rays originate high up on the main dorsal trunk, and are short and thin, not reaching the margin of the bursa. Dorsal ray usually fairly thick, bifurcating distally. A pair of accessory branches spring from the bifureate portion. The terminal branches are bidigitate. Spicules long, filiform. Accessory piece absent or poorly developerl.

Hab. Alimentary tract of Rodents and Marsupials.

Genotype: H. [Strongylus] costellatum (Dujardin, 1845).

Dujardin, 1845, Histoire nat. des Helminthes, Paris, 116; Railliet \& Henry, 1909, Compt. rend. Soc. Biol., Paris, lxvi, 86; Hall, 1916, Proc. U.S. Nat. Mus., 1, 149; Travassos, 1921, Mem. Inst. Oswaldo Cruz, Rio de Janeiro, xiii, 86.

\section{Heligmosomoides Hall, 1916.}

Body commonly coiled spirally. Cuticle with transverse and longitudinal striations, that of the head slightly inflated. Bursa of male wide, without separate dorsal lobe or middorsal incision. Ventral rays divergent from each other. Externo-dorsal rays long and slender, arising separately from the dorsal ray. Dorsal ray extremely short, with four small branches. Prebursal papillae long and apparently within the bursa. Spicules long and filiform. Accessory piece absent. Tail of female truncate, with a slender terminal spike. Eggs segmenting when deposited.

Hab. Intestine of Rodents (one species known).

Genotype : H. [Strongylus] polygyrus (Dujardin, 1845).

Dujardin, 1845, Histoire nat. des Helminthes, Paris, 116 ; v. Linstow, 1878, Arch. f. Naturg., xliv, 2I8; Hall, 1916, Proc. U.S. Nat. Mus., 1, 149; Boulenger, 1922, Parasitol., xiv, 206.

Hall ereeted the genus Heligmosomoides for the reception of $H$. linstowi Hall, 1916 (=S. polygyrus v. Linstow, 1878), believing that $S$. polygyrus v. Linstow was different from 
S. polygyrus Dujardin. The latter species he removed to 'Travassos' genus Viannaia. Boulenger, however, has shown that the species of Dujardin and $\mathrm{r}$. Linstow are identical and should be retained in Hall's genus IIeligmosomoides.

\section{Nematospira Walton, 1923.}

Body spirally coiled. Cuticle of head inflated to form two wing-like swellings, limited behind by an annular constrietion and showing transverse striations. Cuticle of body with faint transverse striations and numerous (over twenty-five) longitudinal ridges. Three small, poorly-defined lips present. Cervical papillae absent or minute. Bursa indistinetly trilobate. Ventral rays fused towards their bases, but rather widely separated distally. Lateral rays all arise from a common trunk, but are well separated distally. Externodorsal rays ahmost parallel, long, but not reaching the margin of the bursa. Dorsal rays paired, very small, originating from the bases of the externo-dorsal rays. Spieules long, slender, usually twisted, grooved on their ventral surfaces. An accessory piece present. Eggs with thin, rugose shells.

Hab. Alimentary tract of Rodents.

Genotype : N. turgida Walton, 1923.

Walton, 1923, Journ. Parcisitol., x, 59, 61.

\section{Heligmostrongylus Travassos, 1917.}

Cuticle transversely striated and with prominent longitudinal markings, of which one appears as a dorsal ala. Cuticle of head dilated. Bursa of male not distinetly separated into three lobes. Ventral rays short and divergent. Postero-lateral ray longer than, and widely divergent from, the remaining lateral rays. Extemo-dorsal rays arise from the eleft portion of the dorsal ray, and are fairly long and slender but do not reach the margin of the bursa. Dorsal ray eleft to its base, its divisions being the longest rays in the bursa. One pair of short accessory branches present, originating abont lialf-way from the tips of the dorsal ray. spieules simple, filiform. An imperfeetly-ehitinized aceessory piece present. Anterior lip of vulva swollen into a pendulous process which may eorer the anus and extend beyond the tip of the tail.

Hab. Small intestine of Rorlents (one species lnnown).

Genotype: H. [Strongylus] sedecimradiatus (v. Linstow, 1899).

v. Linstow, 1899, Mitt. Zool. Mus. Berlin, i, 19; Travassos, 1917, Brazil Medico, Rio de Janeiro, xxxi, 3; 1921, Mem. Inst. Oswaldo Cruz, Rio de Janeiro, xiii, 95. 


\section{Nippostrongylus Lane, 1923.}

Cutiele transversely striated and with ten prominent longitudinal ridges. Cnticle of head inflated. Cervical papillae absent. Bursa of male with a small dorsal lobe and two asymmetrical lateral lobes, the right being larger than the left. In the left lobe the ventro-ventral, latero-ventral, antero-lateral and medio-lateral rays are all thin, tapering and approximately equally separated from eaeh other. The postero-lateral ray is much stouter, strongly divergent and recurved dorsally towards its tip. In the right lobe the ventral rays are thin, the ventro-ventral being divergent from, and shorter than, the latero-ventral, which is elosely applied to the antero-lateral ray. The antero-lateral and medio-lateral rays are stont and closely applied to each other. The postero-lateral ray is short, very slender and divergent. The externo-dorsal rays are within the dorsal lobe and are equal, shor't and slender, arising high up on the median dorsal stem. Dorsal ray fairly thick, bifurcating distally, with a pair of accessory branches just in front of the bifurcation. Its terminations are bidigitate or tridigitate. Spicules simple, rod-shaped. An accessory piece present.

Hab. Alimentary canal of Rodents (one species known).

Genotype: N. [Heligmosomum] muris (Yokogawa, 1920).

Yokogawa, 1920, Journ. Parasitol., vii, 29; 1922, Parasitol., xiv, 127; Lane, 1923, Parasitol., xv, 360.

\section{Viannaia Travassos, 1914.}

Body spirally coiled. Cuticle with faint transverse striations but without longitudinal markings, and enormonsly thickened, especially in the male. Cutiele of head inflated. Lateral lobes of bursa slightly unequal. Ventral rays parallel. Lateral rays more or less equal, diverging at their tips. Externo-dorsal rays originate high up on the median dorsal stem. Dorsal ray relatively long, eleft in its distal third. Its terminations are tridigitate. Spicules equal or subequal, hooked at their tips. Accessory piece present or absent.

Hab. Intestine of Marsupials, Edentates, Insectivores and Rodents.

Genotype: V. viannai Travassos, 1914.

Travassos, 1914, Brazil Medico, Rio de Janeiro, xxviii, 326; 1921, Mem. Inst. Oswaldo Cruz, Rio de Janeiro, xiii, 96; Hall, 1916, Proc. U.S. Nat. Mus., 1, 149, 158.

\section{Viannella Travassos, 1920 (?).}

Body sometimes spirally coiled. Cuticle slightly swollen, with transverse striations. Cuticle of head inflated. Bursa large. Ventro-ventral ray shorter than, and divergent 
distally from, latero-ventral ray. Medio-lateral and posterolateral rays united for the proximal three-quarters of their length in a common trunk which runs parallel to the anterolateral ray. Externo-dorsal rays originate high up on the median dorsal stem. Dorsal ray long, stout, and cleft in its distal half. Its terminations are bidigitate or tridigitate. Spicules relatively short, twisted, foliaceons. Accessory piece rudimentary or absent.

Hab. Small intestine of Rodents.

Genotype: V. [Viannaia] hydrocheri (Travassos, 1914).

Trarassos, 1914, Brazil Medico, Rio de Janeiro, xxviii, 326; 1920 (?), Rev. Vet. e Zootech., Rio de Janeiro, 66; 1920, Rev. Soc. Braz. Sci. (3), 204; 1921, Mem. Inst. Oswaldo Cruz, Rio de Janeiro, xiii, 101.

\section{Impalaia Monnig, 1923.}

Body not spirally coiled. Cuticle with fine longitudinal markings, but transversely striated only towards the anterior end. The cervical region is studded with numerous irregular tubercles. Cuticle of head inflated. Bursa hood-shaped, without well-marked dorsal lobe. Ventral rays separate and forwardly directed. Postero-lateral ray somewhat longer than, and divergent from, the other lateral rays. Externodorsal rays originate, at different levels, near the base of the median dorsal stem. Dorsal ray stout near its base, tapering distally and bifurcate near its tip. Its terminations are bidigitate. Spicules long, filiform. An accessory piece present.

Hab. Intestine of an Antelope (one species known).

Genotype: I. tuberculata Monnig, 1923.

Monnig, 1923, Trans. Roy. Soc. S. Africa, xi, 114.

Appendix to Heliguosominae.

The following genera are referred somewhat doubtfully to this subfamily.

\section{Citellinema Hall, 1916.}

Cuticle of head inflated. Ventral rays and antero-lateral ray originate from a common trunk which itself unites at its base with the common trunk of the medio-lateral and postero-lateral rays. Dorsal ray not examined. Spicules bifureating near their proximal ends to form each two long filiform processes. Female unknown.

Hab. Intestine of a Rodent (one species known).

Genotype: C. bifurcatum Hall, 1916.

Hall, 1916, Proc. U.S. Nat. Mus., 1, 123, 141. 
This genus is insufficiently characterized. Travassos (1921, Mem. Inst. Oswaldo Cruz, xiii, 104) considers that C. bifurcatum much resembles Viannella fariai Travassos. It is possible that Citellinema and Viannella are synonymous, but the point camot be decided until Hall's species is redeseribed.

\section{Warrenius Hall, 1916.}

Cuticle of head inflated. A short, unilateral eervical ala present. Bursa of male deeply incised ventrally to form two large lateral lobes and a small, distinct dorsal lobe. Ventral rays divergent, unusually long and thick. Postero-lateral and medio-lateral rays arise from a common trunk, but are separated distally. Externo-dorsal rays originate from the median dorsal stem near its base and are relatively long and slender. Dorsal ray small, with a pair of short accessory branches just in front of its terminal bifureation. Spieules long and slender. Female unknown.

Hab. Intestine of a Rodent (one speeies known).

Genotype: $W$. quadrivittati Hall, 1916.

Hall, 1916, Proc. U.S. Nat. Mus., 1, 123, 142; Travassos, 1921, Mem. Inst. Osualdo Cruz, Rio de Janeiro, xiii, 103.

Travassos (1921) considers that the presence of a cervical ala is probably an artefact brought about during preservation. He suggests that $W$. quadrivittati closely resembles Heligmosomum aculeatum and $H$. nematodiriforme and ought perhaps to be included in the genus Heligmosomum. As in the case of Citellinema, only a fuller deseription can establish the validity of Hall's genus.

\section{Ollulanus Leuekart, 1865.}

A minute form, with the anterior end generally coiled upon itself. 'The cuticle of the anterior end is invaginated to form a very small, subspherieal buccal cavity. Large cervieal papillae present. Bursa without distinet dorsal lobe or middorsal ineision. Ventral rays separate but parallel. Anterolateral ray much thicker than, but parallel to, the remaining lateral rays. Externo-dorsal rays originate from the median stem of the dorsal ray at about its middle. Dorsal ray comparatively stout, bifurcate distally. Spicules bifurcate distally, one termination being rounded, the other acutely pointed. Accessory piece absent. Tail of female truneate, typically with three terminal cusps or spines, but occasionally with two additional cusps. Vulva at about the beginning of the posterior sixth of the body. Eggs large and few. Mature females with from one to three very large larvae in the body. 
Hab. Stomach, diaphragm and lnngs of Cat. Larvae also in Miee (one speeies lnown).

Genotype: O. tricuspis Lenekart, 1865.

Lenckart, 1865, Arch.f. Naturg., xiii, 227; Cameron, 1923, Joum. Helminthol., i, 157.

\section{Fam. 6. AMIDOSTOMIDAE nov.}

Buecal eapsule very shallow but broad, withont teeth, eutting-plates or leaf-erowns at its anterior margin. Oesophagus typically with three axial chitinoid plates internally. Spicules relatively short, bifureate or trifurcate distally. Vulva in posterior half of body.

The members of this group possess some of the eharacters of the Strongylidae and some of those of the Trichostrongylidae. They eamot conveniently be assigned a definite position in either of these families, and accordingly, small though the group is, we feel compelled to accord it family rank.

\section{Amidostomum Railliet \& Henry, 1909.}

Buecal eapsule very wide, thick-walled, with one or three teeth at its base. Oesophagus with three axial chitinoid plates extending throughout its whole length or reaching to the posterior swelling. Bursa with long lateral lobes and a short dorsal lobe. Externo-dorsal rays arise separately from the dorsal ray and are short. Dorsal ray eleft for a short distance only, and with bidigitate terminations. Prebursal papillae present. Spienles equal, each divided for the greater part of its length into two branches. An accessory piece present. Tail of female long and finger-shaped. Uterine branehes opposed.

Hab. Wall of gizzard of Dueks and other Birds.

Genotype: A. [Strongylus] nodulosum (Rudolphi, 1803) (= S. anseris Zeder, 1800 , e.p.).

Zeder, 1800, Naturg. der Eingeweidewürmer, 73; Rudolphi, 1803, Arch. f. Zool. u. Zoot., Brunswick, iii, 18; 1809, Entozoorum Hist. nat., ii, 230; Railliet \& Henry, 1909, Compt. rend. Soc. Biol., Paris, lxvi, 171; Skrjabin, 1915, Mess. méd. rét. Soc. Petrograd, xxix, 694; Senrat, 1918, Bull. Mus. Hist. nat., Paris, 348.

\section{Epomidiostomum Skrjabin, 1916.}

Cutiele thiek, with conspicuons transverse striations. Head distinet, with a pair of backwardly-directed " nodules" or epaulettes dorsally and ventrally, hooked or blunt at their tips. Buecal earity short. Oesophagus with three internal chitinoid lamellae. Tail of male hooked rentrally. Antero- 
lateral ray short, not reaching the margin of the bursa. Medio-lateral and postero-lateral rays parallel and fused proximally. Externo-dorsal rays short and thick. Terminations of dorsal ray bidigitate. Two large, sessile papillae are situated almost on the lip of the cloaca. Prebursal papillae also present. Spicules short, equal, bifurcate distally. Accessory piece absent. Tail of female long and finger-shaped. Uterine branches opposed.

Hab. Wall of gizzard of Ducks and Geese.

Genotype : E. [Strongylus] uncinatum (Lundahl, 1848).

Lundahl, 1848, Notis. Sällsk. Fauna et Flora Fenn. Förh., Helsingfors, (1) 283; Skrjabin, 1916, Ann. Muss. Zool. Petrograd, xx, 461 ; Seurat, 1918, Bull. Mus. Hist. nat., Paris, (5) 345 .

\section{Amphibiophilus Skrjabin, 1916.}

Buccal capsule resembles that of Amidostomum and is furnished with a large, triangular, pointed denticle at its base. Lateral rays of bursa originate from a common trunk, from which the antero-lateral separates while the remaining rays are still fused for some distance. Externo-dorsal rays arise from the main stem of the dorsal ray. Dorsal ray cleft for about a quarter of its length. Its terminations are tridigitate. Spicules composed of a broad and flat anterior portion and a narrow, cylindrical posterior portion, provided distally with a small hook composed of two branclies. Tail of female slender and pointed.

Hab. Alimentary tract of Amphibia.

Genotype: A. acanthocirratus Skrjabin, 1916.

Skrjabin, 1916, Sci. Res. Zool. Exp. Brit. E. Africa (Dogiel \& Sokolow), 1914, Petrograd, i, (4) 38, 117.

\section{ORDER III. FILARIOIDEA Weinland, 1858.}

Parasitic forms with paired lateral lips, or with or without prominent lip-like structures. Oesophagus without bulb, but divided into a muscular anterior portion and a more glandular posterior portion. Eggs contain embryos when laid or hatch in utero. An intermediate lost probably always necessary for development.

In endeavouring to simplify the classification of the twolipped forms, we have found it impossible to maintain many of the groups that have been proposed. The prevailing tendeney to raise repeatedly the rank of comparatively small groups, without taking a sufficiently broad view of the classification of the Nematodes as a whole, seems to have brought 
about too wide a separation of gromps which, when considered together, are obviously closely related to each other. On this accomnt we have inclucled in the Filarioidea the forms which have been regarded by some authorities as forming a superfamily Spiruroidea, or a suborder Spirurata.

Similarly, the difficulty of finding characters common to all the members of a family, and yet of sufficient importance to separate it from another family, has led us to discard certain families, and to reduce others to the rank of subfamilies. Thus, to take an example, when the characters common to the Acuarinae and the Physalopterinae are reviewed, it is evident that the family Acuariidae is indistinguishable from the family Spiruridae, and it has accordingly been suppressed.

\section{Fam. I. FILARIIDAE Claus, 1885.}

Body usually filiform and much elongated. Head with two lateral and four submedian papillae. Mouth usually without lip-like structures. A simple buccal capsule rarely present. Oesophagus usually with a short anterior muscular portion and a long and thicker posterior glandular portion. Spicules two, usually unequal and dissimilar. Vulva towards the anterior end of the body. Adults in connective tissue, blood-vessels or serous cavities of Vertebrates.

\section{Subfam. 1. FILARIINAE Stiles, 1907.}

Head withont epaulette-like structures. Oesophagus typical. Spicules unequal and dissimilar. Adults in connective tissue, serous carities or blood-ressels of Vertebrates.

The subfamily Onchocercinae Leiper, 1911, does not appear to be a natural group. It is based upon the presence of the spiral thickenings of the cuticle characteristic of Onchocerca. This character does not occur in any of the other genera that have been referred subsequently to the subfamily. Moreover, it is a character that hardly seems to warrant the separation of Onchocerca itself from the subfamily Filariinae. ITe have accordingly suppressed the subfamily Onchocercinae, and have included all its genera among the Filariinae.

\section{Filaria Müller, 1787.}

Cuticle thick, smooth. Mouth small, with six large papillae* (two lateral, fom submedian). In the male two additional pairs of small submedian papillae anterior to the former, and in the female one pair of small subrentral papillae just posterior. Oesophagus short, not distinctly separated into glandular and muscular parts. Tail of male spirally twisted,

* According to Seurat (1920) F. maris has, in addition to six small cephalic papillae, four lips, two of which are lateral, one dorsal and one ventral. 
relatively long, with long and wide alae, which have fine transverse striations, and are continuous behind the extremity of the tail. Caudal papillae variable in number and frequently asymmetrical. Thrce or four pairs of preanal papillae and six to eight pairs of postanal papillae. Spicules two, markedly unequal, the right short and slender, the left several times longer, divided into a proximal solid portion and a distal portion with transversely striated alae. Tail of female blunt. Vulva immediately behind the month, large and oval. Uterus with long eommon trunk and two shorter branches. Eggs with thick shell, eontaining embryos in utero.

Hab. Adults in connective tissue of Vertebrates. Larvae in blood-stream and lymphatie vessels of the same hosts. Intermediate stages in blood-sucking Arthropods.

Genotype: F. martis Gmelin, 1790.

Müller, 1787, Naturforscher, Halle, xxii, 64; Gmelin, 1790, Systema Naturae, 13th ed., 3040; Stiles, 1907, U.S. Pub. Health and Mar.-Hosp. Serv., Hyg. Lab. Bull. 34, 40; Hall, 1916, Proc. U.S. Nat. Mus., 1, 180; Senrat, 1920, Bull. Soc. Hist. nat. Afrique du Nord, Alger, xi, 34; Monnig, 1924, 9th \& 10th Rep. Dir. Vet. Ed. and Res., Pretoria, 435.

The type of the genus Fitaria s.s. is held by Stiles \& Hassall (1905, 106) to be $F$. martis Gmelin, 1790. The identity of this species is somewhat meertain. Seurat (1920) and Monnig (1924) have deseribed forms which they assign to $F$. martis, and their descriptions are, on the whole, in agreement; in neither case, however, was the material colleeted from the type-host. We have been obliged to make use of these specific descriptions in endeavouring to arrive at a satisfactory diagnosis for the genus.

\section{Dirofilaria Railliet \& Henry, 1911.}

Mouth without lip-like struetures. Oesophagus slender. Tail of male short and rounded, with slight alae. Caudal papillae variable in number and asymmetrical. A preanal group generally consisting of three to five pairs of voluminous papillae, and two pairs of ventral adanal papillae present. The postanal papillae consist usually of one large pair and three smaller pairs close to the tip of the tail. Spicules unequal and dissimilar, the longer terminating in a sharp point, the shorter stout and spatulate. Tail of female short and rounded. Vulva some distance from the anterior end of the body. Viviparous. Embryos in blood-stream of host, without "sheath."

Hab. Blood-stream (chiefly right ventriele of heart) and comnective tissue of Mammals.

Genotype: D. [Filaria] immitis (Leidy, 1856). 
Leidy, 1856, Proc. Acad. Nat. Sci. Philadelphia, viii, 55; Weleh, 1873, Month. Micr. Journ., London, x, 157; Fülleborn, 1912, Centralbl. f. Balt., (I) lxv, 341 ; Railliet \& Henry, 1911, Bull. Soc. Path. exot., Paris, iv, 386.

\section{Acanthocheilonema Cobbold, 1870.}

Cuticle with fine transverse striations, or none, or striated only longitudinally. Head blunt, with a pair of lateral papillae, and four submedian papillae which may have double terminations. Oesophagus consists of a relatively short, muscular, anterior portion and a long and stouter, glandular, posterior portion. Tail of male spirally twisted, usually without alae. Three or four pairs of preanal and at least three pairs of postanal papillae present. Frequently also, near the tip of the tail, a pair of small conical lateral appendages. Spicules very unequal and dissimilar; the left long, with a stout, tubular proximal portion and a narrow, filamentous, sometimes alate, distal portion, the right short, usually much stouter and variable in shape. Tail of female moderately long, digitiform, usually with a pair of eonical appendages near its tip. Vulva eircular, near the anterior end of the body. Common trunk of uterus long. Uterine branches parallel. Eggs small, thin-shelled. Viviparous. Embryos without "sheath."

Hab. Serous membranes or vascular system of Mammals. Genotype: A. dracunculoides Cobbold, 1870.

Cobbold, 1870, Proc. Zool. Soc., London, 9; Railliet, Henry \& Langeron, 1912, Bull. Soc. Path. exot., Paris, v, 395; Boulenger, 1920, Proc. Zool. Soc., London, 494; Baylis \& Daubney, 1923, Rec. Ind. Mus., xxr, 564.

\section{Dipetalonema Diesing, 1861.}

Apparently a synonym of Filaria (sens. lat.). No adequate generic definition exists. Diesing's genotype, $D$. candispina, appears to be generally reeognized as a synonym of Filaria gracilis Rudolphi, now referred to Acanthocheilonema Cobbold. If it were proved definitely that $F$. gracilis and $D$. caudispina are identieal, then the name Dipetalonema would supersede Acanthocheilonema.

Diesing, 1861, Sitz. k. Akad. Wiss., Wien, xlii, 620, 703.

5. Wuchereria Silva Araujo, 1877, of Seurat, 1921.

Body tapering anteriorly. Cuticle smooth. Head distinet, rounded, followed by a narrower neck. Mouth eireular, without lips. Two crowns of cephalic papillae present. Oesophagus rather indistinctly divided into two portions. Caudal end of male digitiform, rather sharply curved ventrally, provided with alae. A number of preanal and postanal papillae 
present. Spicules unequal, the longer tapering distally to a long lash with delicate alae and having a spoon-like termination; the shorter thicker, uniform and gutter-like, coarsely marked distally. A small accessory picce present, crescentic in optical section. Tail of female rather long, bluntly rounded. Vulva a little behind the middle of the oesophagus. Vagina with thick, pyriform ovejector, followed by a long, cylindrical tube. Embryos with "sheath."

Hab. Adults in connective tissue of Mammals. Embryos in vascular system of Mammals, and in blood-sucking Insects. Genotype : JV. [Filaria] bancrofti (Cobbold, I877).

Cobbold, 1877, Lancet, ii, 70, 495; Silva Araujo, 1877, Gaz. med. da Bahia, (2) ii, 492, 503; Leiper, 1913, Trans. Soc. Trop. Med. Hyg., vi, 273; Seurat, 1921, Bull. Soc. Hist. nat. Afrique du Nord, Alger, xii, 36; Yorke \& Maplestone, 1926, The Nematode Parasites of Veriebrates, London, 401.

According to Stiles \& Hassall (1920, U.S. Pub. Health Serv., Hyg. Lab. Bull. 114, 881) it is not clear whether Wuchereria Silva Araujo was intended as a new genus, with type filaria, or whether it was a lapsus for Filaria wuchereria. According to Seurat (1921) Silva Araujo's species is a synonym of Filaria bancrofti, and Yorke \& Maplestone follow him in regarding Wuchereria as a genus. We have taken our diagnosis largely from Yorke \& Maplestone (who have examined specimens of the genotype), and have provisionally accepted the genus. It may be noted, however, that there seems to be very little to separate this from Acanthocheilonema, unless it be the "sheathed" condition of the larvae.

\section{Litomosa Yorke \& Maplestone, 1926.}

Syn. Litosoma van Beneden, I873, nec Douglas \& Scott, 1865.

Cuticle transparent, smooth. Head slightly thickened. Mouth without lip-like structuros, leading into a short buccal capsule with thickened walls, narrower in front than behind. Oesophagus short, apparently not divided into two regions. Tail of male digitiform, without alae or papillae, but with a short subterminal point. Spicules unequal; the left long, with a stout proximal portion and a slender, filiform, diatal portion; the right short and broad, with a spatulate process at the tip. Tail of female elongate, digitiform, with two divergent terminal points between which are two small spines. Vulva small, not prominent, situated at the level of the posterior end of the oesophagus. Common trunk of uterus long. Uterine branches parallel.

Hab. Abdominal cavity of Bats (one species known).

Genotype: P. [Litosoma] filaria (van Beneden, 1873). 
van Beneden, 1873, Mém. Acad. Roy. Sci. Belg., xl, 21 ; Seurat, 1921, Bull. Mus. Hist. nat., Paris, i, 103.

7. Hamatospiculum Skrjabin, 1916.

Cuticle with fine transverse striations. Head rounded, with four double submedian and two lateral papillae. Mouth with two salient lateral lip-like struetures. Oesophagus with a narrow anterior portion and a wider posterior portion. Tail of male rounded, with lateral alae. About five pairs of preanal and six pairs of postanal papillae present, all with short peduncles. Spicules two, very unequal and dissimilar; the left with a hooked appendage and nearly ten times as long as the right. Vulva in oesophageal region.

Hab. Subeutaneous conneetive tissue of Birds (one speeies known).

Genotype: II. [Filaria] insigne (Sehneider, 1866).

Sehneider, 1866, Monographie der Nematoden, Berlin, 91 ; Skrjabin, 1916, Journ. Russe Zool., Petrograd, i, 751.

\section{Foleyella Seurat, 1917.}

Narrow lateral alae present, extending throughout the length of the body. Lateral fields wide and conspienous. Mouth with six low papillae and four "outer" papillae. Oesophagus very short, with narrower anterior portion and stouter posterior portion. Reetum narrow and very long. Tail of male with wide caudal alae. About four pairs of preanal and three pairs of postanal papillae present, all peduneulate and very large, except the most posterior postanal pair. An unpaired sessile papilla on the anterior lip of the cloaea. Spieules mequal; the right short and broad. Vulva postoesophageal. Uterine branches run at first posteriorly and parallel, then diverge, the oviduets being situated anteriorly and posteriorly and enlarged into receptacula seminis. Viviparous. Embryos with "sheath," oceurring in blood-stream of host.

Hab. Subeutaneous connective tissue and museles of a Lizard (one speeies known).

Genotype: F. [Filaria] candezei (Fraipont, 1882).

Fraipont, 1882, Bull. Acad. Roy. Sci. Belg., Hxi, 104; Senrat, 1916, Compt. rend. Soc. Biol., Paris, 1133; 1917, Bull. Soc. Hist. nat. Afrique du Nord, Alger, viii, 236.

\section{Onchocerca Diesing, 1841.}

Cuticle thiek, with transverse striations and also spiral thickenings, often interrupted at the level of the lateral fields. In the male usually one thiekening for each striation; in the female the thickenings are at intervals of from two to four 
striations. Mouth without lip-like struetures. Tail of male strongly eurved, flattened ventrally and with narrow alae. Candal papillae variable in number and often asymmetrieal, but always ineluding a group of four pairs of nipple-like adanal papillae. Spieules unequal; the longer spieule tubular in its proximal portion, alate distally, the alae rolled to form a tube; the shorter spicule barbed distally. Tail of female bluntly conieal. Vulva postoesophageal. Viviparous.

Hab. Conneetive tissue of mammals.

Genotype: $O$. reticulata Diesing, 1841.

Diesing, in Hermann, 1841, Repert. Thierh., Stuttgart, ii, 199; Railliet \& Henry, 1910, Compt. rend. Soc. Biol., Paris, i, 249 ; Leiper, 1911, [Rep. to Local Govt. Board, London, No. 45, Food Report 11.] Journ. Trop. Med. Hyg., xiv, 87.

\section{Elaeophora Railliet \& Henry, 1912.}

Mouth without lip-like structures. Oesophagus very long. Tail of male eurved or spirally twisted, without alae. Five pairs of small, sessile eaudal papillae present, of which two pairs are preanal. Spieules unequal; the longer with blunt tip, the shorter witl a knob-like swelling at the tip. Posterior portion of body of female mueh thieker than anterior portion. Uterus divides dichotomously into four branches.

Hab. Nodules in the wall of the aorta of eattle (one species known).

Genotype: E. [Filaria] poeli (Vrijburg, 1897).

Vrijburg, 1897, xi, 43 (fide Stiles \& Hassall, not verified); Railliet \& Henry, 1912, Bull. Soc. Path. exot., Paris, v, 115.

11. Katanga Yorke \& Maplestone, 1926.

Syn. Grammophora Gedoelst, 1916, nec Guénée, 1852.

Body attenuated at each end, especially posteriorly. Head rounded, followed by a slight constrietion. Mouth without lip-like structures. Caudal end conical in both sexes, with three appendages, two of which are lateral and button-like, the third terminal and eylindrical. In the male an adanal group of six pairs of eaudal papillae, and a subterminal pair, present. Spicules unequal, both short and broad. Vulva near anterior end. Common trunk of uterus long.

Hab. Conneetive tissue of a Jumping-shrew (Petrodromus). (One species known).

Genotype : K. [Grammophora] katangensis (Gedoelst, 1916).

Gedoelst, 1916, Rev. Zool. Afric., Brussels, v, 49.

\section{Lemdana Seurat, 1917.}

Cuticle thick, smooth. Lateral fields narrow. Mouth without lip-like struetures. Tail of male short, withont alae. 
One pair of large preanal and one pair of postanal papillae, situated near the cloaca. Spicnles very mequal; the left long and filiform. Vulva in oesophageal region. Ovoviviparous. Embryos in blood-stream of host, without "sheath."

Hab. External surface of crop of Gallinaeeons birds (one species linown).

Genotype: L. marthae Seurat, 1917.

Seurat, 1917, Bull. Soc. Hist. nat. Afrique du Norl, Alger, viii, 208.

\section{Icosiella Seurat, 1917.}

Cuticle thin, transparent. Lateral fields wide. Month with four prominent submedian, rounded papillae, and four small submedian teeth. Oesophagus very long. Intestine narrow and dark-coloured. Tail, in both sexes, short and rounded. In the male the cloaca is bordered by two strong lips. No candal alae or papillae. Spicules nnequal; the left longer. Vulva in oesophageal region. Ovoviviparous. Embryos in blood-stream of host, with "sheath."

Hab. Connective tissue of Frogs (one species known).

Genotype: I. [Filaria] neglecta (Diesing, 1851).

Diesing, 1851, Systema Helminthum, ii, 276; Seurat, 1917, Bull. Soc. Hist. nat. Afrique du Nord, Alger, viii, 240.

14. Politospiculum Skrjabin, 1916.

Cuticle with fine transverse striations. Two narrow lateral alae present, extending throughont the length of the body. Head romded, with two pairs of submedian and one pair of lateral papillae. Mouth with two salient lateral lip-like structures. Oesophagns with a narrow anterior portion and a thicker posterior portion. Tail of male rounded. Four pairs of pedunculate preanal papillae and four pairs of postanal papillae present. Spicules mnequal and dissimilar; the left curved, slightly stouter proximally, the right shorter and straight. Vulva in oesophageal region.

Hab. Articular cavities of Birds (one species known).

Genotype: P. arthricola Skrjabin, 1916.

Skrjabin, 1916, Journ. Russe Zool., Petrograd, i, 753.

15. Setaria Viborg, 1795.

Syn. Crinon Chabert, 1782 ; Crino Lamarck, 1801 ; Hamularia Trentler, 1793, of Stiles, 1907; T'entacularia Zeder, 1800, of Stiles, 1907; ? Amularia Brera, 1810; ? Anchilocephali Brera, 1810; ? Helminthus Dunglison, 1895; Deraiophoronema Romanovitch, 1916; Papillosetaria Verers, 1923. 
Cuticle finely striated transversely, in some species bearing small tubercles. No lateral alae. Mouth surrounded by a raised chitinoid ring, notched laterally and usually also dorsally and ventrally, giving the impression of teeth. Four submedian and two lateral papillae present behind the peribuccal ring. Oesophagus with a short, narrow; anterior portion and a much longer and stouter posterior portion. Tail of male considerably attenuated and spirally twisted. Four pairs of preanal papillae and a median papilla just in front of the cloaca. Three or four pairs of postanal papillae, and usually a pair of small lateral appendages near the tip of the tail. Spicules very unequal and dissimilar; the left long, consisting of a tubular proximal portion and a membranous distal portion, the right short, stout and irregularly shaped. Tail of female conically tapering, curved dorsally, with a pair of lateral appendages near the tip, which is usually knobbed or spiny. Vulva near anterior end of body. Eggs thinshelled. Ovoviviparous.

Hab. Peritoneal cavity of Ungulates and (?) Marsupials.

Genotype : S. [Gordius] equina (Abildgaard, 1789).

Abildgaard, in Müller, 1789, Zool. Dan., iii, 49; Viborg, 1795, Samml. v. Abhandl. f. Thierärzte und Oekonomen, Copenhagen, i; Stiles, 1907, U.S. Pub. Health and Mar.-Hosp. Serv., Hyg. Lab. Bull. 34, 40 ; Boulenger, 1921, Parasitol., xii, 342; Seurat, 1921, Bull. Soc. Hist. nat. Afrique du Nord, Alger, xii, 35; Romanovitch, 1916, Compt. rend. Soc. Biol., Paris, 1xxix, 745; Vevers, 1923, Proc. Zool. Soc., London, 913.

\section{Loa Stiles, 1905.}

Cuticle with numerous irregularly-distributed tubercles or "bosses." Mouth at the summit of a truncate conical process, which is narrower than the succeeding portion of the head. Towards the base of this process are two lateral and four submedian sessile papillae. Ocsophagus short. Tail of male short, bluntly rounded, without alae, slightly curved ventrally. Apparently nine pairs and two unpaired caudal papillae present, the latter on tlie anterior and posterior lips of the cloaca respectively. Of the former four pairs are large lateral papillae with swollen peduncles, forming a group, three of which are preanal and one postanal. Two short, unequal spicules. Tail of female short and rounded. Vulva towards the anterior end of the body. Common trunk of uterus long. Uterine branches two, parallel, both recurving anteriorly at different levels. Eggs hatch in utero.

Hab. Connective tissue, serous membranes and (?) lymphatic system of Man and Primates.

Genotype : L. [Dracunculus] loa (Guyot, 1778). 
Guyot, 1778 (fide Stiles \& Hassall, 1905, not verified); Cobbold, 1864, Entozoa, London, 147; Looss, 1904, Zool. Jahrb., Syst., xx, 549; Stiles, in Stiles \& Hassall, 1905, U.S. Dept. Agric., Bur. Anim. Indust. Bull. 79, 150 ; Stiles, 1907, U.S. Public Health and Mar.-Hosp. Serv., Hyg. Lab. Bull. 34, 34, 40, 42; Leiper, 1913, Trans. Soc. Trop. Med. Hyg., vi, 272; Fantham, Stephens \& Theobald, 1916, The Animal Parasites of Man, 409, 411.

\section{Micipsella Seurat, 1921.}

Body sharply attenuated at both ends. Cuticle not striated, but bearing small, barely salient tubereles, disposed in two alternating rows along each lateral line. No lateral or eaudal alae. Mouth * situated at the summit of a conical process, and surrounded by a ring of small papillae. Two pairs of submedian papillae situated close to the base of this process. Tail in both sexes digitiform, relatively long, spirally twisted, especially in the male. Male with five to seven pairs of preanal and two pairs of postanal papillae. The papillae may be asymmetrically disposed. Numerous tubereles on the dorsal and ventral surfaces near posterior end of male. Spicules short, subequal; the left longer, terminating in a point, the right blunt. Vulva near the posterior end of the oesophagus. Common trunk of uterus long. Uterine branches parallel. Eggs without shell, hatehing in utero. Embryos without "sheaths."

Hab. Peritoneal cavity of a Rodent (one species known).

Genotype: M. [Filaria] numidica (Seurat, 1917).

Seurat, 1917, Compt. rend. Soc. Biol., Paris, lxxx, 354; 1921, Bull. Soc. Hist. nat. Afrique du Nord, Alger, xii, 33.

18. Pelecitus Raillict \& Henry, 1910.

Cuticle with faint longitudinal striations. Head rounded, with a pair of lateral papillae, and four submedian papillae which may be donble. Mouth eirenlar, withont lip-like struetures. Lateral alae extend throughout the length of the body in both sexes. Tail of male truneate, with broad caudal alae. Two to four pairs of preanal papillae present, or none. Postanal papillae vary in number. Spieules subequal, short, transparent, with pointed tips. Tail of female with one or two pairs of peduneulate papillae. Vulva close to anterior end.

Hab. Connective tissue of limbs of Birds (free or in nodules).

Genotype: P. [Spiroptera] helicinus (Molin, 1860).

Iolin, 1860, Sitz. k. Akad. Wiss., Wien, xxxviii, 948; Railliet \& Henry, 1910, Compt. rend. Soc. Biol., Paris, lxviii, 251 ; Skrjabin, 1916, Journ. Russe Zool., Petrograd, i, 748.

* Accorling to Seurat there is a short buccal capsule with chitinoid walls. 
We have placed this genus at the end of the subfamily Filariinae, although its position is rendered somewhat uncertain by the statement of Railliet \& Henry (1910) that lateral alae are present.

\section{Subfam. 2. DIPLOTRIAENINAE Skrjabin, 1916.}

Head provided laterally with a pair of trilobed chitinoid epaulette-like structures ("tridents"), which may be superficially situated or more deeply, at the sides of the oesophagus. Oesophagus typical. Spicules unequal and dissimilar. Adults in conneetive tissue and serous cavities of Birds and Reptiles.

\section{Diplotriaena Railliet \& Henry, in Henry \& O'Zoux, 1909.}

\section{Syn. Triplotriaena Comnal, 1912.}

Head with six ineonspieuous papillae (two lateral, four submedian). Mouth small, circular. Oesophagus with a short, slender, anterior, muscular portion and a stouter, very long, posterior portion. Tail of male short, bluntly rounded or truneate. Up to six pairs of small, sessile, eaudal papillae present. Spicules unequal, dissimilar, the left longer and straight, the right shorter and spirally twisted. Vulva in oesophageal region. Common trunk of uterus long. Uterine branches at first parallel, then divergent. Eggs thick-shelled, containing embryos in utero. Embryos oceur in blood-stream of host.

Hab. Connective tissue of Birds.

Genotype: D. [Filaria] tricuspis (Fedehenko, 1874).

Fedchenko, 1874, Izviest. Imp. Obsh. Liub., etc., Moscow, x, 60; Henry \& O'Zoux, 1909, Bull. Soc. Path. exot., Paris, ii, 547; Seurat, 1915, Novit. Zool., London, xxii, 17 ; Skrjabin, 1917, Parasitol., ix, 471.

\section{Dicheilonema Diesing, 1861.}

\section{Syı. Contortospiculum Skrjabin, 1915.}

Mouth with two strong, prominent, lateral lip-like structures. Head with two lateral and four donble submedian papillae. The posterior lobes of the "tridents" are much expanded. Oesophagus with a short, narrow, anterior portion and a stonter, very long, posterior portion. Tail of male with broad alae supported by five or six pairs of pedunculate preanal papillae and a varying number of pairs of postanal papillae. Spicules unequal and dissimilar; the proximal end of each swollen and clubbed, the distal half of the longer spicule with an aliform expansion, the alae being rolled so as to form a more or less elosed tube, and with serrated edges. The 
shorter spicule is eurved and smooth. Vulva close to anterior end of body. Eggs eontain embryos in utero.

Hab. Connective tissue of Birds.

Genotype: D. [Filaria] labiatum (Creplin, 1825).

Creplin, 1825, Observationes de Entozois, 1; Diesing, 1861, Sitz. k. Akad. Wiss., Wien, xlii, 620, 707; Skrjabin, 1917, Parasitol., ix, 474.

Since Filaria labiata Creplin, the speeies indicated by Stiles \& Hassall (1905) as type of Dicheilonema, is referred by Skrjabin to his genus Contortospiculum, the latter appears to fall into synonymy. Aecordingly, we have taken Skrjabin's diagnosis as that of Dicheilonema. Railliet (1918, Bull. Soc. Zool. France, xliii, 104) (leclined to aceept $F$. labiata as the type of Dicheilonema. He suggested that, sinee Diesing, in defining Dicheilonema, had used the expression "penis vagina tubulosa," and since at that time D. bifidum (Molin) was the only speeies in which the large spieule had already been described as tubular, this speeies should be taken as the type of the genus. The term "vagina penis," so frequently used by Molin and Diesing, appears to us one of very uncertain significance, and it is somewhat arbitrary to assume that it refers to the large spienle. Horeover, as Railliet admits, the species bifidum is insufficiently characterized to distinguish it generieally from Contortospiculum, in which the large spicule may also be described as "tubular."

\section{Hastospiculum Skrjabin, 1923.}

Mouth oval, with two prominently projecting lateral lip-like struetures arising from a broad base. Behind these there are epaulette-like structures, of whieh the posterior ends form each three processes. The head bears two lateral and four double submedian papillae, situated on the epaulettes. The epaulettes are joined dorsally and ventrally by a cuticular band withont papillae. Tail of male with three pairs of preanal papillae. Spicules very unequal; the longer slender, with a spatulate expansion at the tip, the shorter bowshaped and apparently alate. Eggs contain embryos in utero.

Hab. Serous membranes of Reptiles.

Genotype: H. varani Skrjabin, 1923.

Skrjabin, 1923, Russk. Zhurn. Trop. Med., Moseow, i.

4. Serratospiculum Skrjabin, 1915.

Cuticle bearing numerous small papillae or tubereles. Mouth with two trilobed lateral lip-like struetures. Oesophagus with short, slender, anterior muscular portion and long, much wider, posterior glandular portion. Tail of male with small 
alae, which are continuous posteriorly and supported by four to six pairs of preanal and five or six pairs of postanal papillae. Spicules unequal and dissimilar. The middle portion of each spicule is alate, while the smaller bears on the inner side of its distal part a row of scrrations. Vulva close to the anterior end of the body. Eggs thick-shelled, containing embryos in utero.

Hab. Serous cavities of Birds of prey.

Genotype: S. turliestanicum Skrjabin, 1915.

Skrjabin, 1915, Vestn. Obshest. vet., Petrograd, 133; 1916, Ann. Mus. Zool., Petrograd, xx, 546; Seurat, 1915, Novit. Zool., London, xxii, 23.

Subfam. 3. APROCTINAE Yorke \& Maplestone, 1926.

Cuticle thin. Oesophagus atypical, relatively short, not divided into anterior and posterior regions. Intestine darkcoloured. Anus usually not functional, sometimes absent. Tail of male short, bluntly rounded, withont alae and usually without prominent papillae. Spicules short, equal or subequal. Adults in connective tissue of Birds or Reptiles.

1. Aprocta v. Linstow, 1883.

Syn. Lissonema v. Linstow, 1903.

Cuticle smooth. Mouth small, withont papillae. Excretory pore absent. Anus frequently absent, and when present usially not functional. 'Tail of male without papillae. Spicules equal or subequal. Vulva in oesophageal region. Uterine branches parallel. Ovaries and oviducts posterior. Eggs small, thick-shelled, containing embryos in utero.

Hab. Orbit and nasal cavities of Birds.

Genotype: A. cylindrica v. Linstow, 1883.

v. Linstow, 1883, Arch. f. Naturg., xlix, i, $289 ; 1903$, Arch.f. mikr. Anat., lxii, 117; Railliet \& Henry, 1910, Bull. Soc. Path. exot., Paris,-iii, 152; Skrjabin, 1917, Compt. rend. Soc. Biol., Paris, lxxx, 303.

Morphologically there seems to be very little difference between this genus and the two following genera, Thamugadia and Eufilaria. We have retained these genera provisionally, chiefly on account of the differences stated to exist in the eggs and embryos. Eufilaria contains only two species and Thamugadia one, and it seems not improbable that they represent no more than specific differences within the genus A procta. The alimentary canal in all three genera appears to be extremely degenerate, and we do not, therefore, attach great significance to the peculiar structure of the oesophagus in Eufilaria. 


\section{Thamugadia Seurat, 1917.}

Cuticle smooth. Lateral fields narrow, not distinet from the rest of the enticle. Nouth with six small papillae. Tail of male without papillae. Spicules equal. Tail of female digitiform, relatively long. Vulva slightly behind posterior end of oesophagus. Eggs thin-shelled, containing embryos in utero. Embryos with "sheaths," occurring in blood-stream of host.

Hab. Subcutaneous comective tissue of a Lizard (Tarentola). (One species known).

Genotype: T. hyalina Seurat, 1917.

Seurat, 1917, Bull. Soc. Hist. nat. Afrique du Nord, Alger, viii, 237.

See note under Aprocta, supra.

3. Eufilaria Seurat, 1921.

Cuticle smooth. Lateral fields very broad. Excretory pore absent (?). Nouth very small. Oesophagus transparent, short and narrow, formed of a single layer of cells and a cuticular lining. Anus apparently not functional. Tail of male without papillae. Cloaca very small. Spicules subequal. Vulva in oesophageal region. Uterine branches parallel. Ovaries in posterior region. Eggs thin-shelled, hatehing in utero. Embryos without "sheath," occurring in blood-stream of host.

Hab. Subcutaneous connective tissue of Passerine birds.

Genotype: E. sergenti Seurat, 1921.

Seurat, 1921, Bull. Soc. Hist. nat. Afrique du Nord, Alger, xii, 28.

See note under Aprocia, supra.

4. Splendidofilaria Skrjabin, 1923.

Cuticle with fine transverse striations and numerous small tubercles. Mouth withont lip-like structures, but with four submedian papillae. No cervical papillae. Tail of male hooked. Four pairs of postanal papillae present, forming a group. No preanal papillae. Spicules subequal. Tail of female bluntly rounded. Vulva in oesophageal region. Viviparous.

Hab. Circulatory system of Birds (one species known).

Genotype: s. paulouskyi Skrjabin, 1923.

Skrjabin, 1923, Vestn. Microbiol. i Epidem., Saratow, ii, 27.

5. Eucamptus Dujardin, 1845, nec Chevrolat, 1833, nec Dejean, 1833.

Body filiform. Head blunt. Mouth circular, unarmed. Oesophagus cylindrieal. Tail in both sexes blunt, in the male twisted spirally and attenuated posteriorly. Spicules short, equal, curved. No accessory piece. Vulva near anterior end. Common trunk of uterus fusiform. Viviparous. 
Hab. Connective tissue of Birds.

Genotype : E. obtusus Dujardin, 1845.

Dujardin, 1845, Hist. nat. des Helminthes, Paris, 106.

This genus appears to fall into the subfamily Aproetinae. The name Eucamptus, however, is preoceupied, and E. obtusus Dujardin is referred by Yorke \& Maplestone (1926) to their new genus Coronofilaria, the type of which is C. pillersi Yorke \& Maplestone, 1926.

\section{Appendix to Family Filarimda.}

a. Solenonema Diesing, 1861.

The generie diagnosis given by Diesing is quite inadequate. The genotype, by page precedence, would be $S$. [Filaria] aequale (Molin, 1858), but neither this nor either of the other two speeies included in the genus is sufficiently characterized to form the basis of a generic diagnosis. For the present, the genus cannot be distinguished from Filaria, sens. lat.

Molin, 1858, Sitz. k. Akad. Wiss., Wien, xxviii, 383; Diesing, 1861, Sitz. k. Akad. Wiss., Wien, xlii, 620, 704.

b. Tetracheilonema Diesing, 1861 .

$\mathrm{Hab}$. Connective tissue of Birds.

Genotype: T. [Filaria] quadrilabiatum (Molin, 1858).

c. Tricheilonema Diesing, 1861.

Syn. Schizocheilonema Diesing, 1861.

Hab. Unknown.

Genotype: T. [Filaria] megalochilum Diesing, 1851.

\section{d. Monopetalonema Diesing, 1861.}

Hab. Birds (position not stated).

Genotype : M. [Filaria] physalurum (Bremser, in Diesing, 1851).

These three genera are unrecognizable, none of the speeies included being sufficiently well known to enable a diagnosis to be construeted. The species must be regarded as belonging to the genus Filaria, sens. lat.

\section{e. Tipasella Seurat, 1921 (?).}

Lip-like structures not apparent. Oesophagus clearly differentiated into a shorter museular region and a longer glandular region. Tail of male without alae. Spicules short and equal (?).

Genotype : (?).

Seurat, 1921, Bull. Soc. Hist. nat. Afrique du Nord, Alger, xii, 33 . 


\section{f. Microfilaria Cobbold, 1880 , et anett.}

This is not a gencric name, but a colleetive name for immature Filariidae occurring in the blood-stream of Vertebrates.

\section{g. Dermofilaria Rivolta, 1884.}

Aecording to Railliet \& Henry, the type and only species (D. irritans) is the larva of Habronema sp.

Pivolta, 1884, Giorn. Anat., Fisiol. e Patol. Anim., Pisa, xvi, 128; Railliet \& Henry, 1915, Bull. Soc. Path. exot., Paris, viii, $695 \mathrm{ff}$.

\section{Fam. 2. PHILOMETRIDAE nov.}

Body more or less elongated. Anterior end rounded, sometimes with a cuticular shield. Mouth simple, without liplike structures, but surrounded by six or eight papillae. Anus sometimes absent in adult. Male, when known, mueh smaller than female. Spicules two, equal, slender, finely pointed. An accessory piece present. Vulva very ineonspicuous or absent, and vagina rudimentary or absent, in gravid females. Uterine branehes directly opposed, forming a continuous tube. Ovaries relatively very short, situated at opposite ends of the body. Viviparous. Adults in bodycavity, serous membranes or eonneetive tissue of vertebrates.

This family is doubtfully plaeed in the Order Filarioidea, which contains some other atypieal forms. The three genera Philometra, Micropleura and Dracunculus have certain peculiar charaeters in eommon, and it is difficult to refer them to any of the better-established families. A new subfamily, Micropleurinae, within the family Filariiclae, was tentatively proposed by us (1922, Mem. Ind. Mus., vii, 319) to accommodate Micropleura. But in view of the great differences between the female organs of this genus and those typieal of the Filariidae, the erection of a separate family seems a more natural arrangement. A family Draemeulidae appears to have been proposed by Leiper in 1912, to eontain Dracunculus medinensis. Of this speeies, however, the female only has been at all adequately deseribed, and it seems better to take as the type of the family a genus which is better founded, and of which both sexes, and more than one species, are known.

\section{Philometra Costa, 1846.}

\section{Syll. Ichthyonema Diesing, 1861.}

Lateral fields broad. Mouth funnel-shaped, surrounded by suall papillae. Oesophagus relatively short, swollen anteriorly, cylindrieal posteriorly, and aecompanied by a long dorsal unieellular gland which opens into it by a narrow canal 
near the mouth. A pair of small, blind, subventral glands also present. Anus non-functional in adult, the posterior end of the intestine being joined to the body-wall by a solid column of cells. Tail of male truneate, with a pair of large lateral proeesses postcriorly. Cloacal aperture terminal. Spieules equal, sharply pointed. Accessory piece large and well-devcloped. Testis single. Tail of female short and bluntly rounded. Vulva at about the posterior third of the body. Vagina apparently functional only in very young females, subsequently losing its connection with the uterus. Uterine branches form a continuous tube. Ovaries short, usually reflexed.

Hab. Adult in body-cavity and genital glands of Fishes; larva, at least in some eases, in body-cavity of Copepods.

Genotype: P. [Filaria] globiceps (Rudolphi, 1819).

Rudolphi, 1819, Entozoorum Synopsis, 7, 215; Costa, 1846, Ann. Accad. d. Aspiranti nat. di Napoli, iii, 80; Diesing, 1861, Sitz. k. Akad. Wiss., Wien, xlii, 620, 698; Schneider, 1866, Monographie der Nematoden, Berlin, 175; WillemoesSuhm, 1871, Zeitschr. f. Wiss. Zool., Leipzig, xxi, 190 ; v. Linstow, 1902, Arch.f. mikr. Anat., lx, 223; zur Strassen, 1907, Verh. deutsch. zool. Ges., Leipzig, xvii, 110.

\section{Micropleura v. Linstow, 1906.}

Cuticle without striations, but with irregularly-distributed longitudinal series of from two to seven minute tubercles. Two lateral and four submedian cephalic papillae present. Oesophagus with a short anterior muscular portion and a long and wider posterior glandular portion. Tail of male * eonically tapering, with a single, somewhat interrupted, transversely striated ala on the right side, in the preanal region only. Seven pairs of subventral caudal papillae present, of whieh four are postanal and three preanal. Spicules short, equal, very slender and tapering to fine points. A well-chitinized accessory piece present. Tail of female bluntly rounded, with a pair of very large, prominent subventral papillae. Vulva slightly in front of the middle of the body, very inconspicuous. Vagina very short, non-muscular near the vulva. Uterine branches directly opposed, very wide. Ovaries relatively very short, usually reflexed. Embryos hatching in utero.

Hab. Body-eavity and serous membranes of Reptiles (one species known).

Genotype : M. vivipara v. Linstow, 1906.

v. Linstow, 1906, Journ. Proc. Asiat. Soc. Bengal, Calcutta,

* The description of the male given by v. Linstow refers, in all probability, to a different worm. 'The description followed here is that of Baylis (1924).

SYN. NEM. 
ii, 269; Baylis \& Daubney, 1922, Mem. Ind. Mus., vii, 317; Baylis, 1924, Ann. Mag. Nat. Hist., London, (9) xiii, 199.

3. Dracunculus [pre-Limean authors] Kniphof, 1759.

Syn. Vena Gallandat, 1773; Vermiculus Dunglison, 1895.

Body greatly elongated in female. Head with a euticular thickening or shield. Lateral fields broad. Mouth surrounded by eight papillae. Oesophagus very short. Into its lumen there open by narrow canals a very large dorsal and two small subventral unicellular glands. Intestine rudimentary and anus non-functional in adult. Male undeseribed. Tail of female curled ventrally, pointed at tip. Body almost completely filled by the uterus, the two branches of which form a continuous tube. Ovaries short. Vulva apparently absent.* Embryos said to escape through the mouth, by rupture of the uterus, on contact with water.

Hab. Adult in conneetive tissue of Man and other Mammals; larva in body-eavity of Copepods.

Genotype: D. [Gordius] medinensis [pre-Linnean authors] (L., 1758).

Kniphof, 1759, De Pediculis, Erfurt, 12; Bastian, 1864, Trans. Linn. Soc. Lond., xxiv, 101 ; Lenckart, 1876, Die menschlichen Parasiten, Leipzig, ii, 642; zur Strassen, 1907, Verh. dentsch. zool. Ges., Leipzig, xvii, 110.

\section{Fam. 3. SPIRURIDAE Örley, 1885.}

Mouth with two lips. A buceal capsule usually present. Oesophagus with a short anterior muscular portion and a long and thicker posterior glandular portion. Spicules two, usually unequal and dissimilar. Position of vulva variable, but never very elose to anterior end. Eggs thick-shelled, containing embryos when laid. Adults parasitic in Vertebrates; larvae, so far as known, in Arthropods.

\section{Subfam. 1. SPIRURINAE Railliet, 1915.}

Lips followed by a euticular collar, which is prominent dorsally and ventrally, and may form dorsal and ventral shields overlapping the lips. Buceal eapsule without spiral or amnular thickenings. Male typically with four pairs of preanal papillae. An accessory piece usually present.

* The statement sometimes made, that a vulva is present near the mouth, is unintelligible in view of the opposed arrangement of the genital organs. 
1. Spirura E. Blanehard, 1849, nec Diesing, 1861 .

Lips poorly developed, surrounded at their bases by a projecting cutieular collar which is specially prominent dorsally and ventrally. A buccal eapsule present. Body-wall raised some distance from the anterior end into a hump on the ventral surface, serving as a hold-fast. No eervieal alae. Tail of male with well-developed alae. Four pairs of preanal papillae and a single median preeloaeal papilla present. Five pairs of postanal papillae. Spienles somewhat unequal, the shorter alate. Tail of female bluntly eonical and eurved ventrally. Vulva in middle region of body. Uterine branches opposed.

Hab. Alimentary eanal, ehiefly stomach, of Rodents and Inseetivores.

Genotype : S. [Ascaris] talpae (Gmelin, 1790) [- Spiroptera strumosa Rudolphi].

Gmelin, 1790, Systema Naturae, 13th ed., 3032; E. Blanehard, 1849, Ann. Sci. Nat., Paris, Zool., xi, 161; Seurat, 1915, Novit. Zool., London, xxii, 7; Hall, 1916, Proc. U.S. Nat. Mus., 1, 199.

2. Protospirura Seurat, 1914.

Syn. Cephalacanthus Diesing, 1853, e.p.; Mastophorus Diesing, 1853, e.p.

Each lip with three lobes, each of which earries three teeth on its inner surface. A buecal eapsule present. Tail of male with well-developed alae. Four pairs of subventral preanal papillae, with short peduncles, and an unpaired preeloacal papilla. Two pairs of large postanal papillae and a group of small papillae near the tip of the tail. Right spieule longer and stouter than the left, which is alate distally. Tail of female short. Vulva in the middle region of the body. Uterine branches opposed.

Hab. Stomach of small Mammals, ehiefly Rodents.

Genotype: P. numidica Seurat, 1914.

Seurat, 1914, Compt. rend. Soc. Biol., Paris, lxxvii, 344; Hall, 1916, Proc. U.S. Nat. Mus., 1, 203.

\section{Habronema Diesing, 1861 .}

Syn. Cyrnea Seurat, 1914; Dermofilaria Rivolta, 1884.

Cervieal alae may be present. Lips large, entire or trilobed, sometimes with internal teeth, and overlapped dorsally and ventrally by shields of eutiele [sometimes deseribed as dorsal and ventral lips]. A well-developed bueeal capsule present. 'Tail of male with wide alae. Four pairs of preanal papillae and a variable number of postanal papillae, usually 
asymmetrically placed. Spicules very unequal and dissimilar. Vulva in middle region of body, oceasionally displaced posteriorly.

Hab. Stomach of Mammals, proventrieulus and gizzard of Birds.

Genotype: H. [Filaria] muscae (Carter, 1861).

Carter, 1861, Trans. Med. Phis. Soc., Bombay, 62; Diesing, 1861, Sitz. k. Akad. Wiss., Wien, xliii, 270, 273; Ransom, 1913, U.S. Dept. Agric., Bur. Anim. Indust. Bull. 163; Seurat, 1914, Compt. rend. Soc. Biol., Paris, lxxix, 295.

Seurat (1914) proposes the genus Cyrnea for a Spirurid parasite of a partridge whieh, he says, differs from Habronema in the absenee of lateral alae and usually in the presence of an egg-reservoir in the ovejector.

\section{Parabronema Baylis, 1921.}

Syn. ? Squamanema Van Thiel, 1925.

Lips and dorsal and ventral shields resembling those of Habronema. Cuticle of head thiek, folded so as to form a eirclet of six horseshoe-shaped auricular appendages, of which two are lateral and four submedian. Buceal eapsule elongate, eylindrical posteriorly. Tail of male with lateral alae towards its tip, four pairs of preanal and two pairs of postanal papillae, arranged somewhat asymmetrically, and a large median double precloacal papilla. Spicules markedly unequal. Tail of female short, bluntly conical, and curved dorsally. Vulva near posterior end of oesophagus.

Hab. Stomach wall of Elephants and other Mammals.

Genotype: P. indicum Baylis, 1921.

Baylis, 1921, Parasitol., xiii, 58; Khalil, 1922, Proc. Zool. Soc., London, 205; van Thiel, 1925, Ann. Parasitol., Paris, iii, 176.

Squamanema bonnei Van Thiel, 1925, the only species of the genus, is compared by the author with Gongylonema, but appears to is to be much more closely related to Habronema and Parabronema, with the latter of which it is probably identical.

\section{Hartertia Seurat, 1915.}

Lips large, triangular, with trilobed pulp and with three internal lobes. A reduced bneeal capsule present. Lateral cervieal alae may be present. Tail of male with broad symmetrieal alae. Six pairs of pedmeulate caudal papillae present (four preanal and two postanal), and a group of small sessile papillae near the tip of the tail. Spieules very unequal. Accessory piece present. Vulva in middle region of body. 
Hab. Intestine of Birds (one species in a Mammal).

Genotype : $H$. obesa Seurat, 1915.

Seurat, 1915, Novit. Zool., London, xxii, 11.

\section{Histiocephalus Diesing, 1851 .}

Lips large, bearing a pair of lateral cuticular fringes with a variable number of terminal processes having simple or subdivided extremities. Dorsal and ventral shields present as in Habronema. Neck region with a number of longitudinal folds of cuticle. Tail of male with broad alae and six pairs of pedunculate papillae, four preanal and two postanal. Spicules cqual, extremely long and filiform in the genotype; in other species markedly unequal and dissimilar. No accessory piece. Vulva usually towards the anterior end of the body, sometimes behind the middle.

Hab. Beneath the lining of the gizzard of Birds.

Genotype: H. [Spiroptera] laticaudatus (Rudolphi, 1819).

Rudolphi, 1819, Entozoorum Synopsis, 24, 239; Diesing, 1851, Systema Helminthum, ii, 230; Gedoelst, 1919, Compt. rend. Soc. Biol., Paris, Ixxxii, 1145; Skrjabin, 1916, Ann. Mus. Zool., Petrograd, xx, 509; Gendre, 1921, Proc.-verb. Soc. Linn. Bordeaux, lxxiii, 49; and 1922, lxxiii, 138.

\section{Hadjelia Seurat, 1916.}

Syn. Gilsonia Gedoelst, 1919.

Head followed by a constriction. Lateral alae absent. Lips trilobed. Tail of male with well-developed alae, four pairs of preanal and two of postanal pedunculate papillae. Spicules very unequal. No accessory piece. Vulva in oesophageal region.

Hab. Beneath lining of gizzard of Birds.

Genotype : H. lhuillieri Seurat, 1916.

Seurat, 1916, Compt. rend. Soc. Biol., Paris, lxxix, 517; Gedoclst, 1919, Compt. rend. Soc. Biol., Paris, lxxxii, 1145; Gendre, 1922, Proc.-verb. Soc. Linn. Bordeaux, Ixxiii, 132.

\section{Hedruris Nitzsch, 1821.}

Syn. Heteroura v. Siebold, 1836; Synplecta Leidy, 1851.

Body stout posteriorly, slender anteriorly. Lips overlapped by dorsal and ventral shields. Buccal capsule present. Caudal alae of male much reduced or absent. One pair of preanal and at least six pairs of postanal papillae present. Spicules short, equal. Accessory piece present or absent. Posterior end of female can be invaginated to form a suckerlike organ, and has a chitinized claw-like hook for attachment 
to host. Vulva near anus. Eggs oval, with terminal opercula and containing embryos when laid.

Hab. Stomach and mouth-cavity of Amphibia and Chelonia.

Genotype: H. androphora Nitzsch, 1821.

Nitzsch, 1821, Allg. Encycl. Wiss. Kïnste (Ersch \& Gruber), Leipzig, i, 48; Chandler, 1919, Journ. Parasitol., v, 117.

\section{Desmidocerca Skrjabin, 1916.}

Sinall forms with inconspienous lips and, apparently, a enticular ring somewhat resembling that seen in Spirura, especially prominent laterally. A slender buceal capsule present. Oesophagus extremely long. Tail of both sexes bluntly rounded, furnished with a group of small spines or processes at its tip. Spieules unequal. No caudal papillae observed. Vulva in posterior region of body.

Hab. Air-saes of aquatic Birds.

Genotype: D. aërophila Skrjabin, 1916.

Skrjabin, 1916, Ann. Mus. Zool., Petrograd, xx, 530; Seurat, 1920, Bull. Soc. Hist. nat. Afrique du Nord, Alger, xi, 9.

Seurat (1920) has suggested that Desmidocerca ought to be eonsidered as a Filariid. We feel that the position of the vulva and the presence of a buceal capsule indicate the relationship of this genus to the Spiruridae. As Skrjabin has pointed ont, this is an adult form retaining larval eharacters. The spines at the tip of the tail elosely resemble those seen in the larvae of IIabronema and other Spirurid genera.

\section{Subfam. 2. ARDUENNINAE Railliet \& Henry, 1911.}

Lips not prominent, but trilobed. Dorsal and ventral enticular shiekds absent. Buecal capsule or pharynx typically with annular or spiral thickenings in its walls. Asymmetry frequently present in cervical and eaudal alae, and in caudal papillae and other structures of male. Four pairs of preanal and one or two pairs of large postanal papillae present. An accessory piece present.

\section{Arduenna Railliet \& Henry, 1911.}

A cervical ala present on the left side only. Lips trilobed. Two lateral teeth in the oral eavity. Buccal eapsule with spiral cutienlar ridges in its wall. Tail of male with asym. metrical alae. Four pairs of preanal and one pair of postanal peduneulate papillae present. Cloaca surrounded by a serrate cuticular thickening. Spicules very unequal. 
Hab. Adults in stomach of Suidae. Larvae in coprophagous Beetles.

Genotype : A. [Spiroptera] strongylina (Rudolphi, 1819).

Rudolphi, 1819, Entozoorum Synopsis, 23, 237; Railliet \& Henry, 1911, Bull. Soc. Path. exot., Paris, iv, 695; Foster, 1912, U.S. Dept. Agric., Bur. Anim. Ind. Bull. 158, 9.

\section{Simondsia Cobbold, 1864.}

Lateral cervical alae present. Lips inconspicuous. Within the opening of the mouth a large dorsal and a large ventral tooth. Buccal capsule long, cylindrical, with spiral thickenings in its wall. Tail of male short. Four pairs of preanal and one pair of postanal papillae present. Spicules very unequal. Borly of gravid female enlarged posteriorly into a subspherical sac enclosing the uterus and a portion of the intestine.

Hab. Stomach of Suidae.

Genotype: S. paradoxa Cobbold, 1864.

Cobbold, 1864, Entozoa, London, 79; Piana, 1897, Atti. Soc. Ital. Sci. Nat., Milan, xxxvii, 17.

\section{Physocephalus Diesing, 1861.}

Syn. Leiuris Leuckart, 1850 (?); Cephalacanthus Diesing, 1853, e.p.; Mastophorus Diesing, 1853, e. p.

Cuticle of anterior extremity inflated. Three lateral alae on each side. Lips trilobed. Oral cavity small, without teeth. Buccal capsule voluminous, with spiral and annular thickenings in its wall. Tail of male with narrow symmetrical alae. Four pairs of preanal papillae present. Spicules unequal. Vulva in posterior half of body.

Hab. Adults in stomach of Mammals. Larvae in coprophagous Beetles.

Genotype: P. [Spiroptera] sexalatus (Molin, 1860).

Molin, 1860, Sitz. k. Akad. Wiss., Wien, xxxviii, 957; Diesing, 1861, Sitz. k. Akad. Wiss., Wien, xlii, 619, 686; Foster, 1912, U.S. Dept. Agric., Bur. Anim. Ind. Bull. 158; Hall, 1916, Proc. U.S. Nat. Mus., I, 218.

\section{Spirocerca Railliet \& Honry, 1911.}

Lips trilobed, reduced. Within the opening of the mouth six small papillac. Buccal capsule short, expanded anteriorly, without special thickenings. Tail of male with narrow alae. Four pairs of preanal, two pairs of large postanal papillae and a group of small papillae near the tip of the tail. Vulva in anterior region of body. 
Hab. Adults in stomach and oesophagus of Carnivores. Larvae in coprophagous Beetles.

Genotype: S. [Spiroptera] sanguinolenta (Rudolphi, 1819). Rudolphi, 1819, Entozoorum Synopsis, 27, 249; Railliet \& Henry, 1911, Bull. Soc. Path exot., Paris, iv, 695 ; Dujardin, 1845, Histoire naturelle des Helminthes, Paris, 88, 278; Baillet, 1866, Histoire Naturelle des principanx Mammifères domestiques, Paris, 44; Baylis, 1923, Trans. Soc. Trop. Med. IIyg., London, xvi, 492.

\section{Cylicospirura Vevers, 1923.}

Differs from Spirocerca in having six bieuspid teeth at the entrance to the buceal eapsule.

Hab. Stomach of Caruivores.

Genotype: C. [Spiropiera] subaequalis (Molin, 1860).

Molin, 1860, Sitz. k. Akad. Wiss., Wien, xxxvii, 921 ; Vevers, 1923, Proc. Zool. Soc., London, 909.

\section{Streptopharagus Blane, 1912.}

A single cervical ala may be present on the left side. Lips trilobed, very much reduced. Within the opening of the mouth six enticular teeth which may be simple or complex. Buceal eapsule elongate, with irregular transverse ridges in its wall, and forming a half-turn of a spiral in its comrse. Two additional teeth at the anterior end of the bnecal capsule. Tail of male with broad alac. Four pairs of preanal and one pair of postanal peduneulate papillae present, and a group of small sessile papillae near the tip of the tail. Cloaea sometimes partially surrounded by a fringe of cuticular processes. Spicules very unequal and dissimilar. A small aecessory piece present. Vulva in anterior half of body.

Hab. Stomach of mammals.

Genotype: S. armatus Blane, 1912.

Blane, 1912, Compt. rend. Soc. Biol., Paris, lxxii, 456; Seurat, 1917, Bull. Soc. Hist. nat. Afrique du Nord, Alger, viii, 21; 1918, Arch. Inst. Past.Tunis, x, 265; Baylis, 1923, Trans. Soc. Trop. Med. Hyg., London, xxi, 487.

\section{Gongylonema Molin, 1857.}

Syn. Myzomimus Stiles, 1892.

Lips inconspicuous. A short pharynx present. Anterior portion of body with irregular longitudinal rows of cutieular bosses, at least on the left side. Cervical alae present, at least on the left side. Tail of male with asymmetrical alae. A variable number of pairs of preanal and postanal pedunculate 
papillae present. Spicules very unequal. An accessory piece present. Vulva towards the posterior end of the body.

Hab. Adults in mouth, oesophagus, or stomach of Mammals, or crop of Birds, in galleries in the thickness of the mucous membrane. Larvae in Cockroaches and coprophagous Bectles.

Genotype : G. [Filaria] musculi (Rudolphi, 1819).

Rudolphi, 1819, Entozoorum Synopsis, 8; Molin, 1857, Atti. Ist. Veneto di Sci., Lett. ed Arti, ii, 146, 216; Hall, 1916, Proc. U.S. Nat. Mus. 1, 191 ; Baylis, 1925, Journ. Comp. Path. Ther., Edinburgh, xxxviii, 46.

Hall (1916) has proposed a subfamily Gongyloneminae to include only Gongylonema. We consider the formation of a separate subfamily for this genus unnecessary at present. Gongylonema can quite conveniently be appended to the subfamily Arduenninae.

\section{Subfam. 3. ACUARIINAE Railliet, Henry \& Sisoff, 1912.}

Lips conical and quite distinct, but very small. Anterior end provided with "cordons," "epaulettes " or other homologous cuticular structures. Buccal capsule thin-walled, without thickenings. Typically four pairs of preanal papillae in the male. No accessory piece.

\section{Acuaria Bremser, 1811.}

Syn. Anthuris Rudolphi, 1819 ; Spiroptera Rudolphi, 1819; Dispharagus Dujardin, 1845.

Anterior end without vesicular swelling, but bearing four cuticular "cordons" in the form of grooves or bands salient from, or counter sunk in, the cuticle. The cordons extend sometimes directly backwards or, more often, return forwards. They may be joined in pairs across the lateral lines.

Hab. Oesophagus, crop or gizzard (free or in wall) of Birds.

Genotype: A. [Spiroptera] anthuris (Rudolphi, 1819).

Bremser, 1811, Nachricht von einer betrachtlichen Sammlung thierischer Eingeweidewürmer, Vienna, 11, et passim ; Rudolphi, 1819, Entozoorum Synopsis, 25, 243; Railliet, Henry \& Sisoff, 1912, Compt. rend. Soc. Biol., Paris, lxxiii, 622; Baylis \& Daubney, 1922; Mem. Ind. Mus., vii, 321.

This genus includes, in our view (1922, 321), eight subgenera, as follows :-

Subgen. 1a. Acuaria Bremser, 1811, emend. Railliet, Henry \& Sisoff, 1912 .

"Cordons" run straight posteriorly, being non-recurrent and not anastomosed. Six to eight pairs of postanal papillae in the male. Spicules short, thick and subequal. 
Type-speeies: A. (A.) [Spiroptera] anthuris (Rudolphi, 1819). Railliet, Henry \& Sisoff, 1912, Compt. rend. Soc. Biol., Paris, lxxiii, 622; Baylis \& Daubney, 1922, Mem. Ind. Mus., vii, 321.

Subgen. 1b. Cheilospirura (Diesing, 1861) Railliet, Henry \& Sisoff, 1912.

"Cordons" run straight posteriorly, being non-recurrent and not anastomosed. Five to seven pairs of postanal papillae in the male. Spieules very unequal and dissimilar.

Type-species: A. (C.) [Spiroptera] hamulosa (Diesing, 1851).

Diesing, 1851, Systema Helminthum, ii, 217; 1861, Sitz. $h$. Akad. J'iss., Wien, xlii, 618, 683; Railliet, Henry \& Sisoff, 1912, Compt. rend. Soc. Biol., Paris, Ixxiii, 622; Baylis \& Daubney, 1922, Mem. Ind. Mus., vii, 321.

Subgen. 1c. Dispharynx Railliet, Henry \& Sisoff, 1912.

"Cordons" reeurrent, not anastomosed. Usually five pairs of postanal papillae in the male. Spieules mequal and dissimilar.

Type-speeies: A. (D.) [Spiroptera] nasuta (Rudolphi, 1819).

Rudolphi, 1819, Entozoorum Synopsis, 23, 238; Railliet, Henry \& Sisoff, 1912, Compt. rend. Soc. Biol., Paris, Ixxiii, 623-4; Baylis \& Daubney, 1922, Mem. Ind. Mus., vii, 321.

Subgen. 1d. Synhimantus Railliet, Henry \& Sisoff, 1912.

"Cordons" recurrent and anastomosed across the lateral lines. Usually five pairs of postanal papillae in the male. Spieules unequal and dissimilar.

Type-species: A. (S.) [Spiroptera] laticeps (Rudolphi, 1819).

Rudolphi, 1819, Entozoorum Synopsis, 23, 238; Railliet, Henry \& Sisoff, 1912, Compt. rend. Soc. Biol., Paris, lxxiii, 623-4; Baylis \& Daubney, 1922, Mem. Ind. Mus., vii, 321.

Subgen. 1e. Cosmoccphalus Molin, 1858.

"Cordons" sinuous, reeurrent and anastomosed aeross the lateral lines. Extensive lateral alae present. Usually five pairs of postanal papillae in the male. Spieules very unequal.

Type-speeies: A. (C.) [Cosmocephalus] diesingii Molin, 1858.

Molin, 1858, Sitz. k. Akad. I'tiss., Wien, xxviii, 151-2; Railliet, Henry \& Sisoff, 1912, Compt. rend. Soc. Biol., Paris, lxxiii, 622; Seurat, 1919, Norit. Zool., London, xxvi, 186; Baylis \& Daubney, 1922, Mem. Ind. IIus., vii, 320-1.

The only eharaeter that serves to separate Molin's genus Cosmocephalus from the subgenus Synhimantus is the presence of lateral alae. We consider, therefore, that it should be ineluded here as a subgenus of Acuaria. 
Subgen. 1f. Echinuria Soloviev, 1912.

Syn. Hamannia Railliet, Henry \& Sisoff, 1912.

"Cordons " non-recurrent, but anastomosed in pairs. Body sometimes spiny. Four or five pairs of postanal papillae in the male. Spicules unequal and dissimilar.

Type-species: A.(E.) [Echinuria] jugadornata Soloviev, 1912.

Soloviev, 1912, Ann. Mus. Zool., Petrograd, xvii, 110; Railliet, Henry \& Sisoff, 1912, Compt. rend. Soc. Biol., Paris, lxxiii, 623; Seurat, 1919, Novit. Zool., London, xxvi, 179; Baylis \& Daubney, 1922, Mem. Ind. Mus., vii, 321.

Subgen. $1 g$. Rusguniella Scurat, 1919.

Two crescentic cuticular "epaulettes" at anterior end. Lateral alae present, extending from behind the epaulettes. Male unknown.

Type-species : A. (R.) [Spiroptera] elongata (Rudolphi, 1819).

Rudolphi, 1819, Entozoorum Synopsis, 26, 246 ; Seurat, 1919, Novit. Zool., London, xxvi, 184; Baylis \& Daubney, 1922, Mem. Ind. Mus., vii, 321.

Subgen. 1h. Seuratia Skrjabin, 1916.

Syn. Prionostemma Gendre, 1921, e. p.

'Two crescentic cuticular " cpaulettes " at anterior end, with denticulate free edges. Two double rows of spines also present on the body. Spicules unequal.

Type-species: A. (S.) [Gnathostoma] shipleyi (Stossich, 1900) $(=$ Rictularia paradoxa $\mathrm{v}$. Linstow, $1903=$ Acuaria pelagica Seurat, 1916).

Stossich, 1900, Boll. Soc. Adriat. Sci. nat., Trieste, xx, 1 ; v. Linstow, 1903, Ann. Mus. Zool. St. Petersb., viii, 272; Seurat, 1916, Compt. rend. Soc. Biol., Paris, lxxix, 785; Skrjabin, 1916, Compt. rend. Soc. Biol., Paris, lxxix, 973; Baylis \& Daubney, 1922, Mem. Ind. Mus., vii, 321.

\section{Chevreuxia Scurat, 1918.}

Anterior end with four cuticular " cordons" which are nonrecurrent but anastomosed in pairs across the lateral fields. Cuticle in front of cervical papillac raised into a deep conical collar or vesicular swelling. Five pairs of postanal papillae in the male. Spicules very unequal.

Hab. In galleries between coats of gizzard of a Charadriform bird (one species known).

Genotype : C. [Spiroptera] revoluta (Rudolphi, 1819).

Rudolphi, 1819, Entozoorum Synopsis, 26, 247 ; Seurat, 1918, Bull. Soc. Hist. nat. Afrique du Nord, Alger, ix, 106. 
3. Streptocara Railliet, Henry \& Sisoff, 1912.

Syn. Yseria Gedoelst, 1919; Prionostemma Gendre, 1921, e. $p$.

Anterior end surrounded by a cuticular collar with dentieulate or festooned border. Five or six pairs of postanal papillae in the male. Spicules very unequal, the longer provicled distally with one or two reeurrent hooks.

Hab. Beneath lining of gizzard of Birds (ehiefly fislı-eating).

Genotype: S. [Spiroptera] pectinifera (Neumann, 1900).

Neumann, 1900, Rev. vét., Toulouse, xxv, 513-515; Railliet, Henry \& Sisoff, 1912, Compt. rend. Soc. Biol., Paris, lxxiii, 623; Gedoelst, 1919, Compt. rend. Soc. Biol., Paris, lxxxii, 901 ; Gedoelst \& Liégeois, 1922, Compt. rend. Soc. Biol., Paris, lxxxvii, 1237 ; Travassos, 1920 (?), Rev. Vet. e Zootech., Rio de Janeiro, 67.

Travassos has referred this genus, together with Schistorophus, to a subfamily Sehistorophinae Travassos, 1918, within the family Acuariidae. We are in agreement with Railliet (1916) and with Skrjabin (1916) in adopting the view that Schistorophus is more nearly related to the genera ineluded in the family Thelaziidae, while Streptocara, in our view, is referable to the subfamily Aenariinae.

\section{Sciadiocara Skrjabin, 1916.}

Anterior end provided with two lateral pairs of euticular lappets. Six pairs of preanal and five or more pairs of posttanal papillae present in the male. Spieules unequal and dissimilar, the shorter being deeply grooved to form a eanal in which the longer glides.

Hab. Beneath lining of gizzard of Birds.

Genotype: S. [Spiroptera] umbellifera (Molin, 1860).

Molin, 1860, Sitz. k. Alad. Wiss., Wien, xxxviii, 968; Skrjabin, 1916, Ann. Mus. Zool., Petrograd, xx, 519.

\section{Appendix to Acuarinnae.}

\section{Tropisurus Diesing, 1835 .}

Syn. Tetrameres Creplin, 1846; Tropidocerca Diesing, 1851; Astomun Selilotthauber, 1860; Tropidurus Wiegmann, 1835, nec Neuwied, 1824; Acanthophorus v. Linstow, 1876; Microtetrameres Travassos, 1915.

Lips ineonspieuous. A short buceal eapsule present. Cutiele of body may be armed with irregular longitudinal rows of spines. Tail of male withont alae and with a few pairs of sessile papillae. Spieules unequal. The body of the gravid female is enormously distended by the contents of the uterus, 
so that it becomes spindle-shaped or even subglobular. The oesophageal region and the tail remain normal.

Hab. Proventriculus of Birds; males free in lumen, females in nodules in wall.

Genotype : T. paradoxus Diesing, 1835.

Diesing, 1835, Med. Jahrb. k. k. Österr. Staates, Wien, xvi, 83, 93; Travassos, 1914, Mem. Inst. Oswaldo Cruz, Rio de Janeiro, vi, 155; 1915, Braz. Med., Rio de Janeiro, No. 38, 297 ; 1919, Mem. Inst. Oswaldo Cruz, xi, 71; Skrjabin, 1916, Ann. Mus. Zool., Petrograd, xx, 526.

Travassos (1915) proposes to divide the genus Tetrameres into two subgenera, Tetrameres and Microtetrameres. In the former the male is provided with spines along the lateral lines, while in the latter the spines are absent and the long spicule is of excessive length. This subdivision seems to us to be unnecessary. If it were desired to retain the subgenera, the name Tetrameres would have to be changed in accordance with the generic name. The family Tetrameridae, within the Spiruroidea, was proposed by Travassos (1914) for the reception of the genus Tetrameres. We have placed this genus in the Spiruridae, but hesitate to create a special subfamily to contain it.

\section{Crassicauda Leiper \& Atkinson, 1914.}

Cuticle thick, transversely striated, sometimes raised at one point into a swelling or holdfast. Mouth without lips, but: with four submedian papillae and two lateral papillae. The pulp of the lateral papillae divides into two processes, one exterior and the other terminating within the buccal cavity. A buccal capsule present. Mouth and buccalcapsulelaterally compressed. Oesophagus with a relatively short, feebly-muscular anterior portion and a very long posterior portion which is partly muscular, partly glandular, and may be doubled upon itself several times. Tail of male laterally compressed and spirally coiled, with a ventral groove behind the cloaca, within which on either side there is a somewhat irregular row of papillae. Spicules small and unequal, or absent. Anus terminal in female. Vulva in a constricted portion of the body, just in front of the knob-like posterior extremity. Vagina short. Uterine branches parallel, running forwards. Ova thickshelled, containing embryos when laid.

Hab. Urino-genital system or, rarely, other parts of the body of Cetacca.

Genotype : C. [Filaria] crassicauda (Creplin, 1829) nec Leiper and Atkinson, 1914 and 1915.

Creplin, 1829, Nova Acta Phys.-Med. Acad. Nat. Curios., Bonn, xiv, 874; Leiper and Atkinson, 1914, Proc. Zool. Soc., 
London, 266; 1915, Brit. Antarct. ("Terra Nova") Exp., 1910, Nat. Hist. Rep., Zool., ii, (3) 29; Baylis, 1920, Ann. Mag. Nat. Hist., London, (9) v, 418; 1922, Parasitol., xiv, 9.

This apparently aberrant genus is placed here on account of its eonsiderable resemblanee to Tropisurus. It has been treated by some authors as a member of the family Filariidae, but its resemblance to that group is due ehiefly to its elongated form. It is definitely exchuded from the Filariidae by the position of the vulva.

\section{Subfam. 4. PHYSALOPTERINAE Stossich, 1898 (fide} Stiles \& Hassall).

Lips large and entire, with forwardly-projeeting teeth and frequently followed by a cutieular collar, which is entire and does not form dorsal and ventral shields. No buecal eapsule.

\section{Physaloptera Rudolphi, 1819.}

Syn. Chlamydonema Noordhoek Hegt, 1910; Abreviata Travassos, 1920; Leplosoma Travassos, 1920, nec Whitman, 1886 ; Turgida Travassos, 1920.

Each lip armed with a variable number of teeth; typieally a large, external, median tooth and three internal teeth. In addition there may be a row of small denticles on the inner surface. Head usually more or less retraetile within a sheath of euticle. Tail of male with swollen lateral alae which are continuous aeross the ventral surface in front of the eloaca. Four pairs of pedimeulate papillae supporting the alae, generally elose to the eloaea. A variable number of subventral, sessile papillae; usually three pairs preanal and five pairs postanal. Spienles unequal, subequal or equal. Uterus with two, four or many branches.

Hab. Alimentary eanal (generally stomach) of Mammals, Birds and Reptiles, rarely Amphibians.

Genotype: P. clausa Rudolphi, 1819.

Rudolphi, 1819, Entozoorum Synopsis, 29, 255-6, 643; Hall, 1916, Proc. U.S. Nat. Mus., 1, 212; Ortlepp, 1923, Proc. Zool. Soc., London (1922), 1004, 1011.

\section{Heliconema Travassos, 1919.}

Head resembles that of Physaloptera. Tail of male with broad alae, supported by ten pairs of peduneulate papillae, four of which are preanal and one adanal. Spieules very nnequal, the longer filiform and at least ten times as long as the shorter. 
Hab. Stomach of a Fish (one species known).

Genotype: H. heliconema Travassos, 1919.

Travassos, 1919, Arch. Mus. Nac., Rio di Janeiro, xxii, 165.

\section{Thubunaea Seurat, 1914.}

Each lip armed with three teeth on the inner surface. Tail of male with broad alae, supported by eight pairs of pedunculate papillae, of which four pairs are preanal and four pairs postanal. Five to seven pairs of subventral sessile papillae also present. Spicules short, subequal.

Hab. Stomach of Reptiles (one species known).

Genotype: T. pudica Seurat, 1914.

Seurat, 1914, Compt. rend. Soc. Biol., Paris, lxxvi, 724.

\section{Proleptus Dujardin, 1845.}

Syn. Spiropterina van Beneden, 1858; Coronilla van Beneden, 1870; Histiocephalus Molin, 1860, e. p.

Anterior end closely resembling that of Physaloptera. Each lip with a single median conical tooth on its inmer surface. Tail of male with voluminous alae, supported by eight to ten pairs of pedmeulate papillae. Spicules mequal.

Hab. Adults in stomaeh and intestine of Selachians, larvae encapsuled in Decapod Crustacea.

Genotype: P. acutus Dujardin, 1845.

Dujardin, 1845, Hist. nat. des Helminthes, Paris, 105; Seurat, 1919, Bull. Mus. Hist. nat., Paris, No. 3, 166 ; Lloyd, 1920, Proc. Zool. Soc., London, 449.

Although acutus is designated by Stiles \& Hassall (1905) as the type of this genus, we have taken the characters for the diagnosis largely from $P$. obtusus, the commoner and, at present, better known species.

\section{Ochetocephalus v. Linstow, 1907.}

Head with two conical lateral lips, followed by a collarlike fold of cutiele. Behind this, dorsally and ventrally, there is a pair of longitudinal grooves. Oesophagus long. Tail of male conical, with three pairs of preanal and two pairs of postanal papillae, the two anterior preanal pairs laving slender peduncles. Spicules short, broad, equal. Tail of female bluntly rounded, ending in a small spike. Vulva in anterior region of body.

Hab. Body-cavity of Ants (Camponotus).

Genotype: O. javanicus v. Linstow, 1907.

v. Linstow, 1907, Notes Leyden Mus., xxix, 82. 


\section{Subfam. 5. THELAZIINAE nov.}

(= Fam. Thelaziidac Railliet, 1916.)

Lips inconspicuous. Dorsal and ventral cuticular shields absent. Buceal capsule not well developed, without annular or spiral thickenings in its wall. Tail of male typically with numerous preanal papillae. Accessory piece usually absent.

\section{Thelazia Bose, 1819 .}

Cuticle with coarse striations, resembling in profile the teeth of a saw. Lips inconspicuous. A buccal capsule present, having its antcrior edge turned back and ent into six festoons. Tail of male short, without alae. Preanal papillae numerous, including an mpaired precloacal papilla. Three or four pairs of postanal papillae present. Spicules mnequal. Tail of female bluntly rounded. Vulva in anterior region of body. Uterine branches parallel, ruming posteriorly. Viviparous.

Hab. Lachrymal canals of Birds and Mammals.

Genotype: T. [Thelazius] rhodesii (Desmarets, 1828).

Bose, 1819, Journ. Phys., etc., Paris, 1xxxviii, 215; Desmarets, 1828, Veterinarian, London, i, 79; Railliet \& Henry, 1910, Compt. rend. Soc. Biol., Paris, 1xviii, 213; Pailliet, 1916, Journ. Parasitol., ii, 99.

\section{Rhabdochona Railliet, 1916.}

Syn. Pseudancyracanthus Skrjabin, 1923, e.p.; ? Ichthyospirura Skrjabin, 1917.

Lips small. Buccal cavity fumnel-shaped anteriorly, and supported in this region by longitudinal ribs, which project as teeth anteriorly. Tail of male conical, without alae. Numerous preanal and five or six pairs of postanal papillae present. Spicules unequal. Vulva in middle region of body. Uterine branches opposed.

Hab. Intestine of fresh-water Fishes.

Genotype: R. [Dispharagus] denudata (Dujardin, 1845).

Dujardin, 1845, Hist.nat.des Helminthes, Paris, 81 ; Railliet, 1916, Journ. Parasitol., ii, 104; Gendre, 1922, Proc.verb. Soc. Linn. Bordeaux, Ixxiii, 148.

3. Oxyspirura v. Drasche, in Stossich, 1897.

Lips inconspicuous. Mouth surrounded by a small cuticular ring. A short buccal capsule present. Cervical alae may be present. Tail of male laterally compressed, without alae. A very variable number of sessile papillae present, often asymmetrical. Preanal papillae sometimes absent. Spicules very unequal. Vulva in posterior region of body. 
Hab. Orbital cavity of Birds.

Genotype: O. [Spiroptera] cephaloptera (Molin, 1860).

Molin, 1860, Sitz. k. Aliad. Wiss., Wien, xxxviii, 956; v. Drasche, in Stossich, 1897, Filarie e Spiroptere. Lavoro Monografico, Trieste, 123; Railliet, 1916, Journ. Parasitol., ii, 104; Skrjabin, 1916, Ann. Mus. Zool., Petrograd, 529; 1916, Joum. Russe Zool., i, 720, 744.

\section{Cystidicola Fischer v. Waldheim, 1798.}

Syn. Ophiostoma Rudolphi, 1801; Fissula Lamarck, 1801; Ophiostomum Creplin, 1839; Pseudancyracanthus Skrjabin, 1923, e. p.

Lips small and pointed. A cylindrical buccal capsule present. Tail of male rounded, with narrow alae. Numerous double preanal papillae, and four or five pairs of postanal papillae present. Spicules very unequal. Tail of female blunt. Vulva in middle or anterior region. Uterine branches opposed.

Hab. Swim-bladder [rarely vascular system or oesophagus] of fresh-water Fishes.

Genotype: C.farionis Fischer, 1798.

Fischer von Waldheim, 1798, Journ. Phys., etc., Paris, iv, 306 ; 1798, Bull. sci. Soc. philom., Paris, ii, 98; 1799, Arch. Physiol., Halle, iii, 95; Leiper, 1908, Parasitol., i, 193; Railliet, 1916, Journ. Parasitol., ii, 103.

\section{Ceratospira Schneider, 1866.}

Lips inconspicuous. A short buccal capsule present. Tail of male very short and blunt, with broad alae. Nine to eleven pairs of preanal papillae present. Spicules very unequal. Tail of female short and blunt. Vulva in anterior region of body. Oviparous or viviparous.

Hab. Orbital cavity of Birds.

Genotype : C. vesiculosa Schneider, 1866.

Schneider, 1866, Monographie der Nematoden, Berlin, 29, 108; Railliet, 1916, Journ. Parasitol., ii, 99.

\section{Viguiera Scurat, 1913.}

Anterior end covered by a circular disc with a freely pro. jecting border. Buccal capsule cylindrical. Lateral alae absent. Tail of male with broad, asymmetrical alae. Preanal papillae asymmetrical (nine on the left side, seven on the right). Two pairs of postanal papillae present, relatively close to the cloaca. Spicules very unequal. No accessory piece. Tail of female conical. Vulva close to anus. Uterine branches parallel. 
Hab. Betreen coats of proventriculns of Birds.

Genotype: Y. [Spiroptera] euryoptera (Rudolphi, 1819).

Rudolphi, 1819, Entozoorum Symopsis, 26, 248; Seurat, 1913, Bull. Soc. Hist. nat. Afrique du Nord, Alger, v, 223; Gendre, 1922, Proc.verb. Soc. Linn. Bordeaux, lxxiii, 132.

\section{Schistorophus Railliet, 1916.}

Syn. Tetracanthus Hemprich \& Ehrenberg, in Schneider, 1866, nec Hope, 1835.

Lips produced posteriorly into two lateral cuticular flanges, which are drawn out dorsally and ventrally into long points. A buceal eapsule present. Tail of male with lateral alae and numerous preanal papillae. Spicules unequal. Vulva in middle or posterior region of body.

Hab. Beneath lining of gizzard of Birds.

Genotype: S. [Ancyracanthus] longicornis (Hemprich \& Ehrenberg, in Schneider, 1866).

Hemprich \& Ehrenberg, in Schneider, 1866, Monographie der Nematoden, Berlin, 104; Railliet, 1916, Journ. Parasitol., ii, 102; Skrjabin, 1916, Ann. Mus. Zool., Petrograd, xx, 524.

\section{Serticeps Railliet, 1916.}

Lips inconspicuons. Head ornamented with many and variable appendages or festoons. Tail of male blunt, with asymmetrical caudal alae and ten pairs of preanal papillae. Spieules very unequal. Vulva near anus.

Hab. Between eoats of gizzard of a Bird (one species known).

Genotype: S. [Spiroptera] vulvoinflatus (Molin, 1860).

Molin, 1860, Sitz. k. Aliad. Wiss., Wien, xxxviii, 969; Railliet, 1916, Journ. Parasitol., ii, 103.

\section{Appendix to Thelazinae.}

We place here several forms whose relationships are very uneertain. It is possible that the presenee in all these genera of an exterual armature of spines has led to their being erroneously classified together by a number of authors, and that in reality they are not at all closely related to each other. The pecnliar form of the buccal capsule in Rictularia has not umnaturally suggested Strongyloid affinities, and Hall has even referred this genus and Rictularioides to a subfamily Rictularimae of the family Metastrongylidae. We feel, however, that the general characters of Rictularia indicate Spirurid relationships, and the Thelaziinae appear to be the group to which it approaches most closely. 


\section{Spinitectus Fourment, 1883.}

Body armed with transverse rings, closer together anteriorly, bearing backwardly-directed spines. Head retractile. Lips small and pointed. A short buccal capsule present. Tail of male bluntly rounded, with narrow alae. Caudal papillae in one species four pairs preanal and five or six pairs postanal; in another species papillae said to be absent. (Male of genotype unknown). "Denticulate crests" sometimes present in front of the cloaca. Spicules very unequal. Vulva in middle or posterior region of body. Uterine branches opposed. Eggs in genotype with polar filaments.

Hab. Alimentary canal of Fishes.

Genotype: S. oviflagellis Fourment, 1883.

Fourment, 1853, Compt. rend. Soc. Biol., Paris, xxxv, 578; 1854, Ann. Sci. nat., Paris, Zool., xvii, 1; Railliet \& Henry, 1915, Bull. Soc. Path. exot., Paris, viii, 274; Ward \& Magath, 1917, Journ. Parasitol., iii, 61.

In the absence of a full description of the genotype the position of this genus remains don'otful.

\section{Rictularia Frölich, 1802.}

\section{1 .}

Syn. Laphyctes Dujardin, 1845; Pterygodermatites Wedl,

Cuticle of body armed on each side with two longitudinal subventral rows of large, flattened, comb-like spines, at least in the anterior region, the spines becoming searcer and diminishing in size posteriorly. Mouth subterminal, opening dorsally by a transversely elongated aperture bordered by small denticles. A small, well-chitinized buccal capsule present, armed at its base with teeth and spines. Oesophagus simple, slightly club-shaped. Caudal end of male conical, with or withont somewhat bursa-like alae. Several pairs of preanal and postanal papillae present. Spicules short, equal or unequal. An accessory piece present. Vulva near the posterior end of the oesophagis. Uterine branches parallel, rumning posteriorly. Oviparous. Eggs contain embryos when laid.

Hab. Small intestine of Carnivores, Bats and Rodents. A single species recorded from a Lizard.

Genotype : R. cristata Frölich, 1802.

Frölich, 1802, Naturforscher, Halle, xxix, 7 ; Jägerskiöld, 1909, Res. Swed. Zool. Exp. Egypt, No. 25, 41; Hall, 1916, Proc. U.S. Nat. Mus., 1, 168.

\section{Rictularioides Hall, 1916.}

Mouth terminal, surrounded by four conical anterior projections, united in pairs by membranes so as to form two 
lips. Male unknown. Body of female tapering anteriorly, thickened posteriorly, rounded behind, with a terminal eaudal spike. Cuticle bears three lougitudinal series of large, posteriorly-direeted hooks. Internal anatomy undescribed.

Hab. Small intestine of a Rodent (one speeies known).

Genotype: R. [Ophiostomum] amphiacanthum (Diesing, $1851)$.

Diesing, 18.51, Systema Helminthum, ii, 246; v. Drasche, 18s3, Verh.k.k. Zool.bot. Ges., Wien, xxxii, 123; Hall, 1916, Proc. U.S. Nat. Mus., 1, 175.

\section{Pneumonema Johnston, 1916.}

Anterior end eurved slightly dorsally. Lips trilobed. Buecal eapsule greatly reduced or absent. Two suceessive pairs of short eervieal alae present, followed on each side by two longitudinal rows of baekwardly-direeted, thorn-like spines, extending backwards for about one-third of the length of the body, the spines becoming smaller posteriorly. Oesophagus with a short, anterior, museular portion and a longer, glandular posterior portion. Male unknown. Tail of female tapering. Vulva near the middle of the body. Uterine branches opposed. Oviparous. Eggs thin-shelled, containing embryos when laid.

Hab. Lungs of a Lizard (Tiliqua).

Genotype: P. tiliquae Johnston, 1916.

Breinl, 1913, Rep. Ansir. Inst. Trop. Hed. (1911), 39-46; Johnston, 1916, Proc. Roy. Soc. Queensland, Brisbane, xxviii, 58; and 1918, $\mathrm{xxx}, 214$; Yorke \& Maplestone, 1926, The Nematode Parasites of Vertebrates, London, 346.

13. Echinonema v. Linstow, 1898.

Syn. Hoplocephalus v. Linstow, 1898, nec Cuvier, 1 S29.

Cuticle of head somewhat dilated, bearing three circles of long, posteriorly-directed spines. Cuticle of body, in anterior region, also bears numerons spines, arranged in transverse rings and also forming longitudinal rows, and decreasing in size posteriorly. Mouth subterminal. Buccal eavity greatly reduced. Oesophagis relatively short, not distinetly divided into two portions. Tail of male short, conical, without caudal alae. Three pairs of preanal and three of postanal, sessile, subventral papillae, and a more lateral pair at the level of the eloaca. There is also a group of very small papillae near the tip of the tail. Spicules equal, simple, tubular. An accessory pieee present. Tail of female pointed. Vulva at about the anterior third or fourth of the body. Oviparous. Eggs spherieal, containing embryos when laid. 
Hab. Small intestine of a Marsupial (Perameles).

Genotype: E. [Hoplocephalus] cinctum (v. Linstow, 1898).

v. Linstow, 1898, Denkschr. med.-nat. Ges. Jena, (12) viii, 469; 1898, Zool. Centralbl., v, 672; Yorke \& Maplestone, 1926, The Nematode Parasites of Vertebrates, London, 347.

\section{Appendix to Spiruridae.}

a. Oslerus Hall, 1921.

Lips very inconspicuous. Structure of anterior end not definitely known. Two unequal spicules present. Tail of female rounded. Vulva near anus. Ovoviviparous.

Hab. Air-passages of Canidae (one species known).

Genotype: O. [Filaria] osleri (Cobbold, 1879).

Cobbold, 1879, Parasites, London, 304; Hall, 1921, Proc. U.S. Nat. Mus., lix, 541 .

This genus is very imperfectly known. Hall (1921) has suggested that it belongs to the Spiruridae, and is more or less closely related to Gongylonema. This opinion appears to be based on the position of the vulva.

\section{b. Ascarops van Beneden, 1873.}

This name was given by van Beneden to a larval worm, A. minuta van Beneden, found encapsuled in the stomachwall of a Bat. The worm was subsequently referred by von Linstow to Spiroptera, and appears to be a larval Spirurid.

van Beneden, 1873, Mém. Acad. Roy. Sci. Belg., xl, 22; v. Linstow, 1873, Compendium der Helminthologie, 13; 1909, in Brauer, Süsswasserfauna Deutschlands, Heft 15, 65.

\section{c. Cephalacanthus Dicsing, 1853, nec Lacépède, 1802.}

The two species referred to this genus by Diesing are larval Spiruridae, one of them being, according to Seurat, the larva of Protospirura muris, the other probably that of Physocephatus sexalatus.

Diesing, 1853, Sitz. k. Akad. Wiss., Wien, x, 34; Seurat, 1916, Bull. Sci. France et Belg., (7) xlix, 354.

\section{d. Mastophorus Diesing, 1853.}

The two forms referred to this genus by Diesing are apparently larval Spiruridae. One of them, according to Seurat, is the larva of Protospirura muris, the other perhaps that of Physocephalus sexalatus.

Diesing, 1853, Sitz. k. Akad. Wiss., Wien, x, 34; Seurat, 1916, Bull. Sci. France et Belg., (7) xlix, 358. 
Fam. 4. CAMALLANIDAE Raillet \& Henry, 1915.

Lips absent. Mouth a dorso-ventral slit. A large bueeal eapsule present, whose wall is either separated into two lateral seallop-shell-like valves or is eontinuous. Tail of male alate. Spieules unequal and dissimilar. Vulva prominent, in middle region of body. Vagina runs posteriorly from the vulva. Uterine branches opposed; the posterior branch ending blindly, without an ovary.

\section{Camallanus Railliet \& Henry, 1915.}

Syn. Cucullanus anett., nec Mïller, 1777.

Bueeal valves paired, simple, with longitudinal rib-like thiekenings internally. A chitinoid ring at the junetion of the bueeal valves and the oesophagus, and opposite to the dorsal and ventral edges of the valves a pair of trident-shaped chitinoid structures. Right spieule filiform. Aceessory picee absent. Lips of vulva prominent, but not forming a tubular appendage.

Hab. Alimentary eanal of Reptiles, Amphibians and Fishes.

Genotype: C. [Echinorhynchus] lacustris (Zoega, in Mïller, 1777) (= Cucullanus elegans Zeder, 1800).

Zoega, in Müller, 1777, Zoologiae Danicae Prodromus, 214; Zeder, 1800, Erster Nachtrag zur Naturg.d. Eingeweidewürmer, 91 ; Magath, 1919, Trans. Amer. Microsc. Soc., xxxviii, 139; Railliet \& Henry, 191.5, Bull. Soc. Path. exot., Paris, viii, 446; Baylis, 1923, Parasitol., xv, 30.

2. Camallanides Baylis \& Daubney, 1922.

Buecal valves as in camallanus, but each with two large swellings externally. Trident-shaped structures reduced to simple rods. Right spieule alate. An accessory piece present. Vulva earried on a tubular appendage.

Hab. Alimentary canal of Snakes (one speeies known).

Genotype: C.prashadi Baylis \& Daubney, 1922.

Baylis \& Daubney, 1922, Mem. Ind. Mus., vii, 325; Baylis, 1923, Parasitol., xv, 34.

\section{Procamallanus Baylis, 1923.}

Buceal armature a continuous chitinoid capsule, not separated into paired lateral valves. Its wall may be smooth or provided with spiral thickenings internally. No aceessory piece. Tulva with prominent anterior lip.

Hab. Alimentary canal of Siluroid fishes.

Genotype: P. [Cucullamus] laericonchus (Wedl, 1862).

Wedl, 1862, Sitz. K. Akad. Wiss., Wien, xvi, 463; Baylis, 1923, Parasitol., xv, 26, 137. 
Fam. 5. CUCULLANIDAE (s.s.) Barreto, 1916.

Lips large. Mouth a dorso-ventral slit. Oesophagus in two portions, but without a distinct glandular portion, and usually dilated anteriorly to form a large, muscular "false buccal cavity," without a chitinoid lining. Spicules equal. An accessory piece usnally present. A preanal sucker-like organ typically present in the male. Vulva in middle region of body, or posterior. Vagina runs forward from vnlva.

\section{Cucullanus Müller, 1777.}

Syn. Pleurorinchus Nau, 1787; Pleurorhynchus Rudolphi, 1801; Dacnitis Dujardin, 1845; Stelmius Dujardin, 1845; Dichelyne Jägerskiöld, 1902; Bulbodacnitis Lane, 1916; Serradacnitis Lane, 1916.

Anterior end usually bent dorsally. Lips with denticulate border. Preanal "sucker" of male small and fusiform. Caudal alae rudimentary or absent. Vulva very prominent, in posterior half of body.

Hab. Alimentary canal of Fishes and Turtles.

Genotype: C. cirratus Müller, 1777.

Müller, 1777, Zoologiae Danicae Prodromus, i, 4; Railliet \& Henry, 1915, Bull. Soc. Path. exot., Paris, viii, 446; Barreto, 1922, Mem. Inst. Oswaldo Cruz, Rio de Janeiro, xiv, 69 ; Baylis, 1923, Parasitol., xv, 33; 1923, Ann. Mag. Nat. Hist., xii, 233.

The genus Serradacnitis Lane differs only from Cucullanus in possessing " cuticular serration distinct from and in addition to cuticular striation." Bulbodacnitis Lane is defined as "possessing a node or tubercle on the dorsal aspect of the head" (Lane, 1916, Ind. Journ. Med. Res., iv, 97). We do not consider that the characters mentioned warrant the retention of these genera.

\section{Dacnitoides Ward \& Magath, 1917.}

Differs from Cucullanus in having no accessory piece, in the form of the uterus and in the presence of an intestinal caecum. The posterior uterine branch ends blindly (as in the family Camallanidae) and is without an ovary.

Hab. Intestine of fresh-water Fishes.

Genotype: D. cotylophora Ward \& Magath, 1917.

Ward \& Magath, 1917 (1916), Journ. Parasitol., iii, 60; Baylis, 1923, Parasitol., xv, 31.

\section{Seuratum Hall, 1916.}

Syn. Ophiostomum Creplin, 1839, of Seurat, 1915.

Mouth with two lips. No oesophageal bulb. Tail of male with narrow alae. Spicules short, equal or subequal. An 
aecessory picee present. Four pairs of preanal and six pairs of postanal papillae present. Vulva in middle region of body. Uterine branches opposed. Eggs contain embryos when laid,

Hab. Intestine of a Rodent (one species known).

Genotype: S. [Ophiostomum] tacapense (Seurat, 1915).

Seurat, 1915, Compt. rend. Soc. Biol., Paris, Ixxviii, 20; Hall, 1916, Proc. U.S. Nat. Mus., 1, 62; Baylis, 1923, Parasitol., $\mathrm{x} \mathrm{r}, 32$.

Hall (1916) lias suggested a subfamily Seuratinae for the reeeption of Semratum. He considers that this subfamily should be ineluded in the Heterakidae, although admitting that the affinities of the genus are perhaps closer with Dacnitis, now recognised as a synonym of Cucullanus. It differs from Cucullamus in the absence of a sueker-like organ in the male, and in the absenee of a marked dilatation of the anterior end of the oesophagus. It is, however, insufficiently clescribed.

\section{Fam. 6. GNATHOSTOMIDAE Railliet, 1895.}

Lips large, trilobed, having the cuticle of their inner surfaces thickened and usually raised into longitudinal tooth-like ridges which meet or interlock. Vagina rms forward from vulva. Two or four uterine branehes. Eggs with thin shells, ornamented with fine granulations.

\section{Subfam. 1. GNATHOSTOMINAE Baylis \& Lane, 1920.}

Lips followed by a cuticular head-bulb provided either with marked transverse striations or with rows of backwardlydirected hooks, and containing four membranous submedian "ballonets." the earity of each of which is in communication with one of four elongated, blind cervical sacs.

\section{Gnathostoma Owen, 1836.}

Syn. Cheiracanthus Diesing, 1838.

Head-bulb armed with simple hooks, and showing no external eridenee of the presence of the "ballonets." No cuticular collar behind the head-bulb. Body with cutieular" spines, anteriorly seale-like, with their free edges dentate, and posteriorly beeoming less subdivided until finally they appear as simple spines or disappear altogether. Tail of male with four pairs of large lateral and two pairs of small rentral papillae. Spicules unequal. Vulva behind middle of body. Two uterine branches.

Hab. Gastric wall of Mammals (usually of Carnirores).

Genotype: G. spinigerum Owen, 1836. 
Owen, 1836, Proc. Zool. Soc., London, 123; Diesing, 1838, Ber. Versamml. deutsch. Naturf. u. Aerzte in Prag, 189; 1839, Ann. Wien. Mus. Nalurg., ii, 222; Baylis \& Lane, 1920, Proc. Zool. Soc., London, 292.

\section{Echinocephalus Molin, 1858.}

Head-bulb armed with transverse rows of hooks. No external evidence of "ballonets." Body unarmed. No cuticnlar collar behind the head-bulb. Tail of male slightly alate. Eight pairs of caudal papillae present, the most anterior pair always scparated by a long interval from the rest. Spicules slightly unequal. Vulva near posterior end of body. Two uterine branches.

Hab. Intestine (usually in spiral valve region) of Elasmobranch Fishes.

Genotype: E. uncinatus Molin, 1858, emend. Baylis \& Lave, 1920.

Molin, 1858, Sitz. k. Akad. Wiss., Wien, xxviii, 154; v. Linstow, in Shipley \& Hornell, 1904, Rep. Ceylon Pearl Oyster Fisheries, Royal Society, London, 100; Shipley \& Hornell, 1905, op. cit., 54 ; Baylis \& Lane, 1920, Proc. Zool. Soc., London, 275.

\section{Tanqua R. Blanchard, 1904.}

Syn. Ctenocephalus v. Linstow, 1904, nec Kolenati, 1857 ; Tetradenos v. Linstow, 1904; Anomala Travassos, 1920.

Head-bulb coarsely striated transversely, unarmed. Two or four "ballonets," visible externally. Body unarmed. A cuticular collar present behind the head-bulb. Tail of male with well-developed alae. Eight pairs of caudal papillae present, some of which have large swellings on their pulps. Spicules equal. Vulva in posterior half of body. Either two opposed uterine branches, or three anterior and one posterior.

Hab. Stomacl of semi-aquatic Lizards and Snakes.

Genotype: T. [Ascaris] tiara (v. Linstow, 1879).

v. Linstow, 1879, Jahresh. Ver. Vater. Naturk. in Wurttemb., Stuttgart, xxxv, 320; R. Blanchard, 1904, Arch. Parasitol., Paris, viii, 478; Baylis \& Lane, 1920, Proc. Zool. Soc., London, 258.

Subfam. 2. SPIROXYINAE Baylis \& Lane, 1920.

No head-bulb, "ballonets" or cervical sacs. Lips wide, with narrowed base and trefoil-shaped pulp. The thickened portion of the internal cuticle of each lip projects anteriorly as a sharp tooth. 


\section{Spiroxys Sehmeider, 1866.}

Lips wide, with thickened internal cuticle and a sharp anteriorly directed tooth. Cutieular collar rudimentary or absent. Body unarmed. Tail of male alate, with a preanal vesicular swelling and sometimes a preanal sucker-like depression. Eleven pairs of caudal papillae present, of which four are preanal. Spicules subequal. Vulva in middle region of body. Two opposed utcrine branches.

Hab. Stomach of Tortoises.

Cenotype: S. [Spiroptera] contorta (Rudolphi, 1S19).

Rudolphi, 1819, Entozoorum Synopsis, 25, 242; Schneider, 1866, Monographie der Nematoden, 125: Baylis \& Lane, 1920, Proc. Zool. Soc., London, 248; Baylis \& Danbney, 1922, Mem. Ind. Mus., vii, 328 .

\section{Appendix to Gathostonidate.}

The following imperfectly-known genera are provisionally referred to this family.

\section{a. Ancyracanthus Diesing, 1838 .}

Two lateral lips, each bearing a pair of pimnate appendages. Each appendage is connceted with an internal eervical sae. Tail of male with two pairs of large preanal and one pair of small postanal papillae. Spicules long, equal.

Hab. Alimentary canal of Tortoises.

Genotype: A. pectimatus Diesing, 1838 (= A. pinnatifidus Diesing, 1839).

Diesing, 1838, Ber. Versamml. deutsch. Naturf. u. Aerzte in Prag, 189; 1839, Ann.Wien. Mns. Naiurg.,ii, 227; v. Drasche, 1884, Verh. k. k. Zool.-Bot. Ges., Wien, xxxiii, 111 ; Baylis \& Lane, 1920, Proc. Zool. Soc., London, 305.

\section{b. Ancyracanthopsis Diesing, 1861 .}

Each lip with a large onter and a small inner tooth. Tail of male with six to seven pairs of papillae.

Hab. Beneath lining of proventriculus of a Bird.

Genotype: A. [Ancyracanthus] bilabiata (Molin, 1860).

Molin, 1860, Sitz. F. Akad. Wiss., Wien, x1, 343; Diesing, 1861, Sitr. k. Akad. Wiss., Wien, shii, 670; r. Drasche, 1884, Jerh.l. l. Zool.-Bot. Ges., Wien, xxxiii, 112; Raillict, 1916, Journ. Parasitol., ii. 99.

This gems is insufficiently deseribed. The characters mentioned are scarcely sufficient to differentiate it from 
Ancyracanthus. Railliet (1916) suggests placing Ancyracanthopsis and Ancyracanthus in a family Ancyracanthidae. No diagnosis is given either of the family or of the genera.

\section{c. Elaphocephalus Molin, 1860.}

Cuticle of body spiny. Four external cephalic appcndages present, as in Ancyracanthus, but each with a shorter subsidiary process. Four cervical sacs present.

Hab. At base of toes of a Macaw (one species known).

Genotype: E. octocornutus Molin, 1860.

Molin, 1860, Sitz. k. Akad. Wiss., Wien, xl, 343; v. Drasche, 1884, Verh. k. k. Zool.-Bot. Ges., Wien, xxxiii, 113; Baylis \& Lane, 1920, Proc. Zool. Soc., London, 306.

\section{Appendix to Filarioidea.}

a. Haplonema Ward \& Magath, 1917.

Head without lips or papillae. Cervical alae present. No buccal capsule. Oesophagus in two portions. 'Tail of male without alae. Two pairs of preanal and three pairs of postanal papillae present. Spicules equal. Apparently no accessory piece. Vulva in middle region of body. Uterine branches opposed. Oviparous.

Hab. Intestine of a fresh-water Fish (one species known).

Genotype : H. immutatum Ward \& Magath, 1917.

Ward \& Magath, 1917 (1916), Journ. Parasitol., iii, 61.

b. Ascarophis van Beneden, 1871.

Syn. Ascaropsis Power \& Sedgwick, 1880.

Body relatively clongate, of uniform girth. Cuticle, except at extremities, with prominent annulations. Head with two small, forwardly-projecting spines. Lips paired, small. Oesophagus long. Nale undescribed. Anus of female in a ventral depression. Tail short and conical. Vulva apparently anterior. Genital tube apparently single, posterior. Oviparous. Eggs with two filaments at one pole.

Hab. Intestine and pyloric caeca of marine Fishes.

Genotype: A. morrhuae van Beneden, 1871.

van Beneden, 1871, Mém. Acad. Roy. Sci. Belg., xxxviii, (4), 92; Nicoll, 1907, Ann. Mag. Nat. Hist., (7) xix, 92.

\section{ORDER IT. DIOCTOPHYMOIDEA Railliet, 1916.}

Body sometimes spiny. Each of the four muscular fields divided longitudinally into two by the insertion of extremely well-developed suspensory muscles of the alimentary canal. 
Month hexagonal, surrounded by one, two or three cireles each of six papillae. Oesophagns relatively long, simple or club-shaped. Tail of male furnished with a "bursa," withont rays. A single long spicule present. Anus of female terminal. Female genital tube single. Eggs barrel-shaped, with thick, pitted, albuminous coating and not containing embryos when laid. Adults parasitic in Mammals and Birds. Larval forms in an intermediate host.

\section{Fam. 1. DIOCTOPHYMTDAE Railliet, 1916.}

Syn. Eustrongylidae Leiper, 1308; Jägerskiöld, 1909.

With the characters of the Order.

\section{Dioctophyme Collet-Meygret, 1802.}

Syn. Eustrongylus Diesing, 1851.

Extremely large forms (up to $1 \mathrm{~m}$. in length in female). Male little more than one-third of the length of the female. Cuticle relatively thin and transparent. Body blood-red during life. Eaeh lateral line with a row of papillae, which become closer together at the extremities. Body truneate posteriorly, somewhat tapering anteriorly. Mouth surrounded by two circles each of six papillae, the anterior small, the posterior large. The transversely-elongated, oval "bursa" is indented on its anterior margin, without rays proper, but supported by a triradiate structure in the centre of which is the eloacal opening. The entire margin of the "bursa " is bordered by papillae. Spicule bristle-like. Tail of female bears a number of small papillae near the anus, which is erescentic. Vulva towards the anterior end of the body, but postoesophageal.

Hab. Adult: kidney and peritoneal cavity of Mammals. Larva: in musculature of fresh-water Fishes.

Genotype: D. [Ascaris] renatis (Goeze, 1782).

Goeze, 178:, Naturg. d. Eingeweidewïmer, 39, 73; ColletMeygret, 1802, Journ. Phys., ete., Paris, lxv, 4.5S; Stiles, 1901, Zool. Jahrb., Syst., xv, 167; Lenckart, 1868, Die Menschlichen Parasiten, Leipzig and Heidelberg, ii, 353; Dujardin, 1845, Hist. nat. des Helminthes, Paris, 113 ; Sehneider, 1866, Monographic der Nematoden, Berlin, 49.

\section{Eustrongylides Jägerslziöld, 1909.}

Forms of medinm or rather large size. Body cylindrieal, or sometimes swollen in its midclle. Cuticle eoarsely striated, at least towards the extremities, but without spines. Mouth snrounded by twelve or eighteen papillae, arranged in two or three circles. Vulva close to anus. 
Hab. Adults in glands of proventrieulus of Birds, mostly fish-eaters. Larvae in comnective tissue of Fishes and (?) Crustacca.

Genotype : E. [Strongylus] tubifex (Nitzsch, 1819).

Nitzsch, in Rudolphi, 1819, Entozoorum Synopsis, 31; Jägerskiöld, 1909, Nov. Act. Reg. Soc. Sci. Upsala, ii, No. 3, 45; Ciurea, 1924, Zeitschr. f. Fleisch-und-Milchhyg., Berlin, xxxiv, 134 .

\section{Hystrichis Dujardin, 1845.}

Forms of medium or rather large size. Head usually more or less swollen, sometimes subspherical. Body cylindrical, or sivollen in its middle portion. Cuticle eoarsely striated towards the extremities and bearing spines, which may be confined to the anterior region of the body, or to the swollen head. Mouth surrounded by a single circle of six papillae. Vulva elose to anus.

Hab. In glands of proventrieulus of aquatic or semi-aquatic Birds.

Genotype: $H$. tricolor Dujardin, 1845.*

Dujardin, 1845, Hist. nat. des Helminthes, Paris, 290; Jägerskiöld, 1909, Nov. Act. Reg. Soc. Sci. Upsala, ii, No. 3, 46.

\section{ORDER V. TRICHINELLOIDEA Hall, 1916.}

Body more or less clearly divided into an oesophageal portion and a posterior portion which eontains the other organs. Oesophagus a euticular tube embedded in a single ehain of cclls. Anus terminal or subterminal in both sexes. Male with a single spicule or none. Vulva at junction of oesophageal and posterior portions of body. A single ovary and uterus.

This group, although it contains only a small number of genera, eonsists of very highly-specialized forms. The subfamilies are necessitated by the wide divergences between the genera.

Fam. 1. TRICHINELLIDAE Stiles \& Crane, 1910.

With the eharacters of the Order.

\section{Subfam. 1. TRICHINELLINAE Ransom, 1911.}

Male without spicule or spicule-sheath. Female ovoviviparous. Egg spherical, without true shell but surrounded by a

* Jägerskiöld (1909) designates H. acanthocephalicus (Molin) as genotypo. Dujardin's genus contained only one species, $H$. tricolor, which therefore must be the type. 
delicate membrane. Adults in the intestine give rise to larvae which become encapsuled in the musculature of the same host.

\section{Trichinella Railliet, 1895.}

Syn. Trichina Owen, 1835, nec Meigen, 1830.

With the characters of the Subfamily.

Hab. Adult in intestine of Mammals. Larvae encapsuled in museles of same host.

Genotype: T. [Trichina] spiralis (Owen, 1835).

Owen, 1835, Trans. Zool. Soc., London, i, 315; Railliet, 1895, Traité de Zoologie médicale ct agricole, P'aris, 1303; Hall, 1916, Proc. U.s. Nat. Mus., l, 10.

\section{Subfam. 2. TRICHURINAE Ransom, 1911.}

Male with one spieule or, exceptionally, with only a spiculesheath. Eggs lemon-shaped, with thick shell and polar opercula; their contents unsegmented when laid. Development, so far as known, direct.

\section{Trichuris Roederer, 1761 .}

Syn. Trichocephalos Goeze, 1782; Trichocephalus Sehrank, 1788 ; Mastigodes Zeder, 1800, nec de Blainville, 1828.

Oesophageal portion of body very slender, and longer than the thicker posterior portion. Posterior extremity blunt and rounded in both sexes. On the ventral surface of the oesophageal portion there is a longitudinal "bacillary band." Posterior portion of body of male eurled dorsally. Spienle in a protrusible prepnee-like sheath, of which the external surface, when protruded, may be smooth or spiny. Vulva in posterior portion of body, near its junetion with the oesophageal portion. Eggs lemon-shaped, with thick, usually brown, shells and polar opereula.

Hab. Caecum of Mammats, forming burrows in the epithelium, in which the anterior end is inserted.

Genotype: T. [Ascaris] trichinra (L., 1771).

Roederer, 1761, Götting. Anz.v.gelchrt. Sachen, i, 243; and 1762, ii, 41; Hall, 1916, Proc. U.S. Nat. Mus., 1, 20.

\section{Capillaria Zeder, 1800.}

Syn. Trichosoma Rudolphi, 1819: Trichosomum Creplin, 1839; Calodium Dujardin, 1845; Thominx Dujardin, 1845; Liniscus Dujardin, 1845; Eucolens Dujardin, 1845.

Body very slender. Oesophageal portion shorter than, or rarely equal in length to, the posterior portion. A longi- 
tudinal "bacillary band" may be present. Spicule long and slender, with a protrusible sheath, the outer surface of which, when protruded, may be smooth or spiny. Tail of male may be faintly alate. Eggs lemon-shaped, with polar opercula.

Hab. Alimentary canal of Vertehrates.

Genotype: C. tumida Zeder, 1803 (= capillaris Rudolphi, 1809).

Zeder, 1800, Erster Nachtrag zur Naturg. der Eingeweidewïrmer, Leipzig, 5; 1803, Anleitung zur Naturg. der Eingeweidewürmer, Hamburg, 61 ; Rudolphi, 1809, Entozoorum... Historia Naturatis, i, 86; Hall, 1916, Proc. U.S. Nat. Mus., $1,33$.

\section{Hepaticola Hall, 1916.}

Oesophageal portion of body shorter than posterior portion, which is only slightly thicker. "Bacillary band " apparently absent. Spicule absent, but a membranous sheath present. Eggs with polar opereula, and shell (in genotype) apparently striated in optical section.

Hab. Liver of Mammals.

Genotype : H. [Trichocephalus] hepatica (Bancroft, 1893).

Bancroft, 1893, Journ. \& Proc. R. Soc. N.S.W., Sydney, xxvii, 86; Hall, 1916, Proc. U.S. Nat. Mus., 1, 30.

\section{Subfam. 3. TRICHosomoIdiNAE Hall, 1916.}

Male without spicule or spicule-sheath, and parasitic in the vagina or uterus of the femalc. Eggs thick-shelled, with polar opercula, and containing embryos when laid. Development direct.

\section{Trichosomoides Raillict, 1895.}

Syn. Trichodes v. Linstow, 1874, nec Herbst, 1792.

Oesophageal region of body not markedly more slender than posterior region. "Bacillary band " apparently absent.

Hab. Urinary organs of Rodents (one species known).

Genotype: T. [Trichosoma] crassicauda (Bellingham, 1840).

Bellingham, 1840, Mag. Nat. Hist., London, iv, 349; Railliet, 1895, Traité de Zoologie médicale et agricole, Paris, 1302 ; Hall, 1916, Proc. U.S. Nat. Mus., 1, 12. 


\section{Appendix to Nematoda.}

A. Fam. DRILONEMIDAE Pierantoni, 1916.

We place here five aberrant and little-known genera parasitic in Earthworms, whose organization is so modified that their position in the system is very uneertain. They have been made into three separate families-Onycidae, Cephalonemidae and Drilonemidae-by Pierantoni, but several of the genera appear to be based on unsatisfactory characters, and we regard them as synonyms. All the remaining genera seem to us to lave certain characters in common, and it appears possible to regard them as all belonging to a single family, for which Pierantoni's name Drilonemidae may be retained.

The family may be defined as follows:-Small forms with or without a pair of ehitinoid hooks overhanging the mouth. Oesophagus short and simple, or absent. Male with two spicules and an aecessory piece, or without any such organs. Female genital tube single, running anteriorly from the vulva, then turning posteriorly and extending to the hinder part of the body. Oviparous. Parasitic in the eoclomic cavity or musenlature of Earthworms.

\section{Drilonema Pierantoni, 1916.}

Syn. Mesonema Pierantoni, 1916; Opistonema Pierantoni, 1916.

Head narrower than neck. Month nnarmed, terminal. Oesophagus short, cylindrical or slightly elub-shaped, apparently muscular, followerl by a much wider intestine. Male much smaller than female, with a blunt tail which may be of great relative length. Spicules absent. Testis reflexed. Vulva in front of or behind the midclle of the body.

Hab. Free in coelomic cavity of Earthworms.

Genotype: D. wendessianum Pierantoni, 1916.

Pierantoni, 1916, Boll. Soc. Nat. Napoli, xxviii, 152, 154, 15.5.

The generic separation of Mesonema and Opistonema from Drilonema does not appear to be justifiable. Mesonema inchudes, according to Pierantoni, two species of which the males are unknown, and the females differ from those of the species of Drilonema almost solely in having the vulva situated somewhat further back. In the three speeies of Opistonema the vulva is still further baek, but there appears to be no other ground for the erection of a separate genus. 


\section{Pierantonia nom. nov.}

Syn. Cephalonema Pierantoni, 1916, nec Cobb, 1893.

Head distinct, eomposed of two lateral thickenings, between which is the mouth. Month unarmed, without papillae. Oesophagus non-muscular, not distinet from intestine. Bexes constantly found in copula. Male much smaller than female. Spicules absent. Tail of female suddenly constrieted, with terminal spike. Vulva at about the posterior fourth of the body, or behind it.

Hab. Coelomic cavity of Earthworms.

Genotype: (by page precedence) C. microcephalum Peirantoni, 1916.

Pierantoni, 1916, Boll. Soc. Nat. Napoli, xxviii, 149.

\section{Pharyngonema Pierantoni, 1923.}

Neek region swollen. Anterior end with minute bristles. An ovoid, muscular pharyngeal bulb present, followed immediately by the intestine. Male unknown. Tail of female short, acutely pointed. Vulva at about the middle of the body.

Hab. Coelomic cavity of Earthworms.

Genotype: P. mekongianus Pierantoni, 1923.

Pierantoni, 1923, Boll. Mus. Zool. Torino, xxxviii, (1) 2.

\section{Dicelis Dujardin, 1845.}

Mouth round, unarmed. Oesophagus short, muscular, club-shaped, followed by a wider intestine. Tail, in both sexes, blunt, carrying a pair of large, lateral sucker-like organs surrounded by radiating fibres. Male with a pair of slightlycurved spicules and an aceessory piece.

Hab. Sperm-sacs of Earthworms.

Genotype : D. filaria Dujardin, 1845.

Dujardin, 1845, Hist. nat. des Helminthes, Paris, 107; Johnson, 1913, Quart. Journ. Micr. Sci., Iviii, 606, 608; Pierantoni, 1916, Boll. Soc. Nat. Napoli, xxviii, 157.

According to Johnson (1913), Dicelis is simply a new name for larvae of Rhabditis inhabiting the nephridia and spermiducal canals of earthworms. This, however, cammot very well be the ease, since Dujardin was evidently dealing with adult worms and not larvae. 


\section{Synoeenema Magalhães, 1905.}

Syn. Dionyx Perrier, 1881, nec Le Peletier \& Serville, 1825.

Moutl subterminal, apparently usually turned dorsally, and overhung by two lateral, recurved, chitinoid hooks springing from its anterior (ventral) margin. Oesophagus chub. shaped. Tail of male relatively long and tapering. Two short, stout spicules and a broad, triangular accessory piece usually present. Vulva in the anterior half of the body. Sexes sometimes permanently in copula.

Hab. In eysts in the musenlature, or free in the coelomie eavity, of Earthworms.

Genotype: S. [Dionyx] lacazii (Perrier, 1881).

Perrier, 1881, Arch. Zool. exp. et gén., Paris, ix, 242; Magalhães, 1905, Arch. Parasitol., Paris, ix, 315; Pierantoni, 1916, Boll. Soc. Nat. Napoli, xxviii, 148.

The name Dionyx being preoceupied, it seems legitimate to adopt Synoecnema Magalhães as the generic name. We have, however, retained Dionyx lacazii Perrier as the genotype.

\section{B. GENERA INCERIAE SEDIS.}

The following genera are either so anomalous in structure or so imperfeetly described that it is impossible at present to determine their affinities.

\section{Agamonematoideum Diesing, 1853.}

This name was given by Diesing (Sit: k. Akad. Wiss., Wien, $x, 35$ ) to a larval form found in a beetle (Blaps mortisaga). According to Seurat (1916, Bull. Sci. France et Belg., xlix, 351) this is probably the seeond-stage larva of a species of Gongylonema.

\section{Amblyura Ehrenberg, in Hemprich \& Ehrenberg [1828],} 1831.

Body filiform, smooth. Head not distinct, truneate. Mouth cireular, surrounded by bristles. Tail tapering, slightly swollen at the tip by the presence of a spinneret. Male with a single spicule. Vulva in the middle of the body. Female genital tubes paired.

Hab. Fresh water (?).

Genotype: Probably A. [Vibrio] serpentulus (Müller, 1773).

Müller, 1773, Vermium terrestrium ... Historia, 42; 1786 , Animalcula Infusoria, ete., 61; Hemprich \& Ehrenberg [1828], 1831, Symbolae Physicae (Evertebrata), Ser. Prima, sig. a (unp.). 
The charaeters mentioned above are all of any importanee that we can find in the original account of the genus and its presumed genotype. The genus is probably unrecognizable. It is placed by Schneider among the synonyms of Enoplus.

\section{Anguillina Hammerschmidt, 1838.}

Under the name of Anguillina monilis Hammerschmidt $(1838$, Isis $(5), 358)$ describes a worm found in the intestine of a beetle (Aphodius conspurcatus). The deseription and figures are insufficient to enable the position of the worm to be determined.

\section{Aphelenchoides Fischer, 1894.}

The description of $A$. kiihnii Fischer, the sole species of this genus, is not accessible to us.

Hab. Parasitic in stems of Clematis.

Fischer, 1894, Ber. d. phys. Lab. d. landw. Inst. Halle, Dresden, iii (1), 1 .

5. Buddenbrockia Schröder, 1910.

This generic name is applied to certain worm-like parasites oceurring in the body-eavity of Plumatella. It is included here because, although Schröder originally described Buddenbrockia as a Meźozoan form, he subsequently regarded it as a Nematode. This later opinion does not, however, seem to be borne out by the deseription. The absence of a euticle and the presence of an external epithelium appear to exclude this genus from the Nematoda, apart from the entirely anomalous nature of its anatomy and the mode of origin of its eggs.

Genotype : B. plumatellae Sehröder, 1910.

Schröder, 1910, Zeitschr. f. wiss. Zool., xcvi, 527; 1912, Verh. naturh.-med. Ver. Heidelberg, N.F., xi, 230; 1912, Zeitschr.f. wiss. Zool., cii, 79.

\section{Calyptronema Marion, 1870.}

Borly elongate. Buccal eavity carried on a protrusible oesophageal tube and situated in the middle of a sort of membranous collar, which ordinarily surrounds the headregion, but is capable of being projected forward. Male with two long and slender spicules. Accessory piece absent.

Hab. Marine.

Genotype: C. paradoxum Marion, 1870.

Marion, 1870, Ann. Sci.nat., Paris, Zool., (5) xiii, Art. 14, 12.

We quote the main characters mentioned by Marion. The genus, however, appears to be quite unrecognizable, and the 
figures suggest that the "protrusible oesophageal tube" was a moulted cuticle, carrying with it the oesophageal lining.

\section{Choronema Cobb, 1920.}

Cutical thin, finely striated, withont bristles. Lateral alae present. Head not distinct, without lips, papillae or bristles. Lateral organs mncertain. Pharynx "absent or obseure." Oesophagus cylindroid, slightly swollen behind. Tail with two sublateral papillac. Spimneret absent. Description based on an immature, monlting specimen.

Hab. Soil.

Genotype: C. simplex Cobb, 1920.

Cobb, 1920, Contr. Sci. Nematol., ix, 238 and key; Nicoletzky, 1922, Arch. $f$. Naturg., Abt. A, lxxxvii, 570.

Nicoletzky (1922) believes $C$. simplex to be closely related to a larval Tylenchus described by him, and it seems possible that Choronema should be regarded as a synonym of Anguitlutina. Cobb, however, compares it with "a deteriorated Cephalobus or Diplogaster."

\section{Cystoopsis Wagner, 1867.}

Male very small, cylindrical. Female with anterior portion of body cylindrical and posterior portion swollen into a globular sac. Cuticle fincly striated. Month surrounded by a low cuticular ring. Buccal cavity funnel-shaped. Alimentary canal without posterior opening, the cylindrical oesophagus ending in a blind sac or bladder-like enlargement. Candal end of male rounded, with a tubular terminal projection upon which the genital tube appears to open, and which is regarded by v. Linstow as a "penis." Spicules absent. Vulva in the slender anterior portion of the body, near the head. Female genital tube apparently single. Oviparons. Egg-shells thick, with polar plugs. Eggs embryonated when laid.

Hab. Subcntaneons nodules in a Fish (Acipenser).

Genotype: C. acipenseris Wagner, 1867.

Wagner, 1867, Arb. 1. Kongr. russ. Naturf., Sitz. zool. Sekt., 6 [quoted by r. Linstow]; Zykov, 1902, Biol. Centralbl., Leipzig, xxii, 229; v. Linstow, 1904, Arch.f. Naturg., lxx, i, 297.

\section{Dikentrocephalus Wedl, 1855.}

Syn. Dicentrocephalus Diesing, 1861.

Small worms with the head-end trmmeate and having two rounded lips, between which are two processes which, when extruded, appear as a fused "stylet." Oesophagus short. Posterior end rounded, with two distinct lateral ridges and four papillac. 
Hab. Parasitic in a Fish (Lophius piscatorius).

Genotype: D. crinalis Wedl, 1855.

Wedl, 1855, Sitz. k. Akad. Wiss., Wien, xvi, 384.

Wedl's description of this worm is very inadequate, and he makes no distinction between the sexes. It may be a larval form, but it seems possible that the orientation of the worm was mistaken, and that the protrusible processes of the "head" were in reality the spicules of the male.

\section{Diplolaimus v. Linstow, 1876.}

Cutiele minstriated. Head with a hemispherical expansion, which has fine bristles on its periphery, is divided by longitudinal furrows and shows internally several chitinoid rings. The lumen of the anterior fifth of the oesophagus is funnelshaped, with elitinized walls. The oesophagus is greatly thickened behind this fumnel, and is also somewhat swollen behind, but has no bulb. The tail is finely pointed, and a caudal gland is present.

Hab. Fresh water.

Genotype: D. gracilis v. Linstow, 1876.

v. Linstow, 1876, Arch.f. Naturg., xlii, i, 16.

It appears quite impossible to determine the relationships of this genus. According to Micoletzky, the genotype is probably the larval form of a parasitic species.

\section{Eubostrichus Greeff, 1869 .}

Body long and filiform, enclosed in a peculiar eovering of closely entangled or eemented hairs. This covering is apparently not a part of the cuticle, and may be a secretion. Head not distinct, with bristles. Month-opening funnelshaped. "Oesophagus" cylindrical, narrow, without bulb or with a posterior muscular bulb. Male unknown. Anus of female terminal.

Hab. Marine.

Genotype : E. filiformis Greeff, 1869 (by page precedence).

Greeff, 1869, Arch.f. Naturg., xxxv, i, 117.

The anatomy and systematic position of this genus are very uneertain. From Greeff's figures it seems possible that the organ deseribed as the oesophagus may in reality be a long, tubular buccal capsule, or even a stylet like that of the Anguillulinidae, and that the true oesophagus may have been mistaken for the begiming of the intestine. In E. filiformis the "oesophagus" is figured as a simple, cylindrieal tube, while in the other speeies, E. phalacrus Greeff, it has a muscular (?) bulb at its postcrior end. 


\section{Eustoma van Beneden, 1871.}

van Beneden (1871, Mém. Acad. Roy. Belg., xxxviii, 19, 92) gives no description of the worm named by him Eustoma truncatum, which was found in Raja clavata. He gives two figures (Pl. III, fig. 9) which apparently represent two views of the head, but its characters are very vagucly indicated.

\section{Filarina Hammerschmidt, 1838.}

The worm named Filarina vitrea by Hammerschmidt (1838, Isis (5), 358), and found by him in the intestine of a beetle (Trichius hemipterus), is unrecognizable. Possibly it was a larval Spirurid.

\section{Labyrinthostoma Cobb, 1898.}

This name occurs in the legend to a figure, thus:- "Fig. 65.-Head of a species for the reception of whieh the author proposes the new genus Labyrinthostoma. The pharyngeal bulb is here well developed." There is no further description, and the species is apparently not named or otherwise indicated.

$$
\text { Cobb, 1898, Agric. Gaz. N.S.W., Sydney, ix, } 421 .
$$

\section{Lineola Kölliker, 1845, nec Baer, 1827.}

Body thread-like, tapering at each end. Mouth "anständig," surrounded by six small feelers. Oesophagus long, somewhat thickened behind. Testis single, moniliform. Two spicules present. Ovaries paired, short and broad. Vulva in middle of body.

Hab. Marine (among sea-weed).

Genotype: L. sieboldii Kölliker, 1845 (by page precedence). Kölliker, 1845, Verh. schueiz. naturf. Ges., xxix, 86.

\section{Lumbricicola Friedländer, 1895.}

The name Lumbricicola vasorum was given by Friedländer (1895, Zeitschr.f. wiss. Zool., 1x, 278) to some small Nematodes found by him in the blood-vessels of an Earthworm. The worms were only studied in sections, and the deseription given of them does not enable us to form any opinion as to their systematic position.

\section{Mitrephorus r. Linstow, 1877, nec Sehoenherr, 1837.}

Slender forms with smooth euticle. Head hemispherical, distinct, with two rows of "openings," each with a swollen border, running up into a small stalk. The anterior row consists of four such "openings," the posterior of eight. Oesophagus swollen behind into a slight bulb, containing a 
heart-shaped chitinoid body. Male unknown. Vulva a little behind the middle of the body. A caudal gland present.

Hab. Fresh water.

Genotype: M. haemisphaericus v. Linstow, 1877.

v. Linstow, 1877, Arch. f. Naturg., xliii, i, 2.

According to Micoletzky (1922, Arch. f. Naturg., Abt. A, lxxxvii, 620) this is probably the larva of a parasitic form. The fact that, although he only saw "undeveloped " females, v. Linstow mentions the presence of a vulva, is somewhat opposed to this view. In any case, the description is such that it is impossible to determine the systematic position of the worm.

\section{Nema Leidy, 1856.}

"Body ascaridiform. Head without appendages. Mouth unarmed, large, infundibuliform, oesophagus tubular, membranous, expanding into a simple straight intestine; anus ventral. Tail conical, acnte, recurved. Generative aperture near the middle of the body."

Hab. About dead specimens of a Phryganea.

Genotype : $N$. vacilans Leidy, 1856.

Leidy, 1856, Proc. Acad. Nat. Sci. Philadelphia, viii, 49.

19. Phacelura Ehrenberg, in Hemprich \& Ehrenberg, 1831.

Head not distinct. Tail with rounded tip, bearing four to eight styliform appendages.

Hab. Parasitic in fresh-water Snails.

Genotype: P. paludinae Ehrenberg, 1831.

Ehrenberg, in Hemprich \& Ehrenberg, 1831, Symbolae Physicae, Pars Zool., Decas I, Appendix, Phytozoa Entozoa, sig. $a$; Diesing, 1851, Systema Helminthum, ii, 137.

20. Phanoglene Nordmann, 1840, nec Eberth, 1863.

Body filiform, smooth, pointed behind. Mouth truncate, bilabiate, provided with cirri. Neck marked with very red eyes. Penis of male single.

Hab. Genotype in the larva of a Neuropterous insect.

Genotype: P. micans Nordmaun, 1840.

Nordmann, in Lamarck, 1840, Hist. nat. des Animaux sans Vertèbres, 2nd ed., Paris, iii, 664.

\section{Phlyctainophora Steiner, 1921.}

Body stont, in the shape of an irregular, curled eylinder. Cuticle with about fifteon more or less spherical vesicles, almost symmetrically placed on the two sides of the body, 
and an unpaired vesicle at the head-end. The tail-end bears a pair of vesicles. Mouth in a shallow depression on the anterior surface of the head-vesicle. Anus in front of the posterior pair of vesicles. Body-wall apparently without musenlature. Naie unknown. Body of female eontains a uterus and a thin-walled gut. The body-cavity is filled with embryos, whieh extend even into the vesieles, by the rupture of which they probably eseape. Vulva apparently absent.

Hab. Connective tissue of a Shark (Lamna), between the hyomandibular areh and the skull.

Genotype: P. lamnae Steiner, 1921.

Steiner, 1921, Centralbl.f. Bakt., (1), lxxxvi, 590.

22. Piguris Sehlotthanber, 1860.

The deseription of $P$. reticulata Schotthauber, 1860 , from the colon of the horse, does not enable its systematic position to be determined.

Schlotthanber, 1860, Versamml. deutsch. Naturf. u. Aerzt., xxxi, 126.

\section{Pontonema Leidy, 1855.}

"Body eapillary, narrowing towards the extremities. Head contimuous with the body, truncated, or obtuse and surmounted with angular papillae, eirrated. Eyes none. Tail obtuse. Generative aperture ventral, near the middle of the body. Oesophagus long, cylindroclavate; gizzard none, intestine straight, capacious ; anus ventral and posterior."

Hab. Marine.

Genotype: P. vacillatum Leidy, 1855.

Leidy, 1855, Journ. Acad. Nat. Sci. Philadelphia, (2) iii, 144; 1856, Proc. Acad. Nat. Sci. Philadelphia, viii, 49.

24. Potamonema Leidy, 1856.

"Body filiform, narrowing towards the extremities. Head eontinuous with the body, slightly dilated, obtuse. Mouth large, infundibuliform, unarmed; oesophagns narrow, flexuous, membranous, gradually expanding into a eapacious, straight, eylindrical intestine; anus none (?) or exeeedingly indistinct. Caudal extremity obtuse. Generative aperture of the female near the middle of the body."

Hab. Fresh water.

Genotype: P. nitidum Leidy, 1856.

Leidy, 1856, Proc. Acad. Nat. Sci. Philadelphia, viii, 49.

25. Prochelmins $\mathrm{v}$. Linstow, 1888.

An elongate form, of large size for a free-living Nematode, rounded at both extremities, the posterior end being the thicker. 
Cuticle firm and thick, containing two systems of fibres erossing each other. Musculature holomyarian, not interrupted by longitudinal fields. Oesophagus relatively short. Tail very short. Reproductive organs unknown.

Hab. Marine (1,950 fathoms).

Genotype : P. profundissima v. Linstow, 1888.

v. Linstow, 1888, Challenger Exp., Zool., lxxi, 11.

The description is based on two immature speeimens.

\section{Pseudochromadora Daday, 1901.}

Body of uniform thickness, except posteriorly, where it tapers gradually. Cuticle thick, with well-marked striations. No cephalic papillae or bristles, but near the anterior end there are four conspicuous sucker-like "warts." Buccal cavity without euticular structures. Oesophagus with a more or less oval posterior bulb, having an oval lumen thickly lined with euticle. Male $u$ known. Tail of female relatively short, with a short, "leaf-shaped" terminal point. Vulva in middle of body. Female genital tubes paired. A single (?) caudal gland present.

Hab. Fresh water.

Genotype: P. quadripapillata Daday, 1901.

Daday, 1901, Termès. Füzetek, Budapest, xxiv. 7; Micoletzky, 1922, Arch.f. Naturg., Abt. A, lxxxvii, 620.

\section{Pterygifer v. Linstow, 1907.}

Cuticle transversely striated. Head rounded, with four movable, wing-like plates, which are attached in front, concave behind. Each plate has at its posterior end an inwardlyprojecting hook-like process. Oesophagus one-fifth of the total length. Male inknown. Tail of female rounded. Vulva somerwhat behind the middle of the body. Oviparous.

Hab. Parasitic in a Fish (Symbranchus).

Genotype : P. tetrapteryx v. Linstow, 1907.

v. Linstow, 1907, Mitt. Zool. Mus. Berlin, iii, 255.

v. Linstow's description and figure of this worm are practically mintelligible, and though the structure of the head, as described, is somewhat reminiscent of Habronema and Hedruris among the Spiruridae, we are quite unable to assign the worm to a definite position.

\section{Scolecophilus Baylis \& Daubney, 1922.}

Body short and stout, tapering more gradually in front than behind. Cuticle thin and smooth. Lateral fields very conspicuous, broad, granular, increasing in width posteriorly 
and bending towards the ventral surface near the tail. Head truncate, without recognizable lips or papillae. Oesophagus slender, with a large, oblong, glandular posterior bulb, connected with the intestine by a narrow neck containing some kind of valves. Intestine morlified into a fat-body. Anus absent. Tail of male blunt, strongly curled ventrally. Candal papillae apparently absent. Two equal spicules present, broad at the base and bent ontwarks at right angles in the middle, with their tips deeply bifurcate. An accessory piece present, with a triangular dorsal portion and two lateral processes. Vulva near the anterior end of the body. No muscular vagina. A single functional uterine branch, with ovary, present, rumning posteriorly. A blind sac, lying parallel to the anterior portion of this, and acting as an egg-reservoir, probably represents the second uterine branch. Eggs oval, with thin shell, containing a crescentic embryo in utero.

Hab. Body-cavity of an Earthworm (Perionyx).

Genotype: S. lumbricicola Baylis \& Daubney, 1922.

Baylis \& Daubney, 1922, Mem. Ind. Mus., vii, 338.

The affinities of this curions genus are at present impossible to determine. It appears to have no close relationship with the parasites of earthworms which have been referred to the family Drilonemidae (supra, p. 240).

29. Stenodes Dujardin, 1845.

Slender, elongate worms. Cuticle finely striated. Two slight lateral alae present. Head small, distinct, truncate, followed by a narrower neck. An imperfect buccal capsule or horny disc present, in the middle of which is the circular month. Oesophagus club-shaped, followed by a distinct "ventriculus." Tail of male pointed, curled. Two long, equal spicules present. Two pairs of small preanal "suckers", [? large papillae] present. Tail of female straight, acute. Vulva at anterior third of body. A single nterns present. Oviparous. Eggs with reticulate or alveolate shell, and containing embryos when laid.

Hab. Unknown-presumed to have been parasitic in a foreign Mammal which had been kept in captivity in Paris.

Genotype: S. acus Dujardin, 1845.

Dujardin, 1845, Hist. nat. des Helminthes, Paris, 264.

\section{Uracanthus Diesing, 1861.}

Uracanthus brevispinosus Diesing, 1861, is Leidy's "Nematoideum cavitatis abdominis Passali cornuti" renamed. The worm described by Leidy was a larval form found in the body. 
cavity of the beetle, Passalus. In all probability it is a Spirurid larva, but Leidy's description and figures do not enable us to determine its position.

Leidy, 1852, Trans. Amer. Phil. Soc., Philadelphia, n.s., X, 241 ; Diesing, 1861, Sitz. k. Akad. Wiss., Wien, xlii, 728.

\section{Urolabes Carter, 1858.}

"The largest specimens are one-sixth of an inch long, bilabiate, with an exsertile, sharp-pointed oesophagus; the hepatic sheath ending some distanee from the termination of the intestine; the vulva opens in the female a little in front of the middle of the body, and the amus posteriorly, just before the body terminates suddenly in a whip-like tail. The penis in the male is exsertile from the anus, very nearly close to the posterior extremity of the body, which is so obtuse as to be almost truncated."

Hab. Fresh water.

Genotype : U. palustris Carter, 1858.

Carter, 1858, Ann. Mag. Nat. Hist., London, (3) i, 414.

According to Micoletzky (1922, Arch. f. Naturg., Abt. A, lxxxvii, 442), the genotype of Urolabes is doubtfully referable to Dorylaimus, all the other species being unreeognizable.

\section{UNRECOGNIZABLE FORMS.}

The following names occur in the literature of the Nematoda, but cannot be recognized as valid genera. Some of them are nomina nuda, while others refer to objects which do not appear to have been Nematodes.

1. Chaos Linnaeus, 1767.

Although this gemus included the worm known as Anguillula rediviva, it has as its type a Protozoan form, and cannot there. fore be recognized as a genus of Nematoda.

2. Crinon Chabert, 1782.

Syn. Crino Lamarek, 1801 ; Crinola Rafinesque, 1815.

This is unrecognizable as a genus of Nematoda, but is possibly in part a synonym of Setaria.

Chabert, 1782, Traité des maladies vermineuses, Paris, 21 ; Lamarck, 1801, Système des Animaux sans Vertèbres, Paris, 339.

3. Diplasia von Holten, 1802.

The name Diplasia trichiuri was given by von Holten (1802, Skr. af Naturh.-Selsh., Copenhagen, v, 27) to a worm found in the abdominal eavity of a fish. As Stiles \& Hassall (1920) 
suggest, the worm does not appear from the figure to have been a Nematode. It has rather the appearance of a Cestode, and may have been a larval Tetrarhynchus.

\section{Discophorus Mehlis, in Creplin, 1844.}

Discophorus tenax Mehlis (in Creplin, 1844, Arch.f. Naturg., $\mathrm{x}, 125)$ is a nomen nudum except for the mention of the host (Raja clavala). Writing again in 1846, Creplin (Arch.f. Naturg., xii, 149) mentions D. tenax Mehlis as "nematoideum non descriptum."

5. Ditrachyceros Hermann, in Sultzer, 1801.

Syn. Ditrachyceras Sultzer; Ditrachycerosoma Brera, 1809; Diceras Rudolphi, 1810, nec Lamarck, 1805; Dirhynchus Rudolphi, 1810.

The human " parasites " named Ditrachyceros by Hermann (in Sultzer, 1801, Dissertation sur un ver intestinal, ete., Strasbourg), and subsequently renamed Diceras rude by Rudolphi (1810, Entozoorum . . Historia Naturalis, ii (2), 258), appear not to have been worms at all, but the seeds of a plant, as was suggested by Bremser (1819, Über lebende Wurmer im lebenden Menschen, Wien, 261).

\section{Liorhynchus Rudolphi, 1801.}

The type of this genus is indeterminable, and the name must therefore lapse. It is a partial synonym of Spinitectus and perhaps of other genera.

\section{Needhamia Carns, 1839.}

The objects found in the vas deferens of Sepia, and deseribed by Carus (1839, Nov. Act. Acad. Caes. Leop.-Car., Breslau and Bonn, xix, i, 1) under the name of Needhamia expulsoria, appear to have been simply the spermatophores of the Sepia itself.

\section{Onchophora Kroyer, 1840.}

Syn. Oncophora Diesing, 1851.

Body divided into two portions, of which the anterior is very long and slender. Posterior portion thicker, shorter, and bearing a hump * near the junetion of the two portions. Hale mknown. Tail of female pointed. Viviparons.

* This hmmp, according to Pudolphi, may perhaps represent the vulva. The description was based on two females, of which the anterior cnds appear to have been missing. If the animal is a Nematode (which seems uncertain), its shape suggests affinities with the Triehinellikae, subfamily Trichminae. The fact that it is stated to be viviparous, however, is against this, and nothing whatever is known of the internal anatomy. Diesing is referred to by Kroyer (1840), and possibly is the author of the name Onchophora, in a personal communication. So far as Kroyer is concerned, the name is a nomen nudum except for the mention of the host. 
Hab. Gall-bladder of a Fish (Thynnus).

Genotype : O. [Trichocephalus] gibbosa (Rudolphi, 1819) (=O. neglecta Diesing, 1851).

Rudolphi, 1819, Entozoorum Synopsis, 639; Krøyer, 1840 , Danmarli's Fiske, Copenhagen, i, 596 ; Dujardin, 1845, Hist. nat. des Helminthes, Paris, 41 ; Diesing, 1851, Systema Helminthum, ii, 81, 296.

\section{Pontamonema v. Linstow, 1878.}

This name appears to be due to a confusion between Pontonema and Potamonema Leidy, and speeies of both genera are mentioned under it. 349 .

v. Linstow, 1878, Compendium der Helminthologie, Hanover,

10. Proboscidea (Bruguière, 1791) Cuvier, 1798.

Aecording to Stiles \& Hassall, the genotype of this genus is indeterminable. In any case it appears to be a composite group, ineluding species not only of Nematoda but also of Acanthocephala.

\section{Protostrongylus Leiper, 1908.}

This name is mentioned by Leiper (1908, Rep. Wellcome Res. Lab., Khartoum, iii, 191) among genera attributed to his subfamily Metastrongylinae. No species is mentioned, and the name appears to be a nomen nudum.

12. Rhytis Mayer, 1839, nec Zeder, 1803.

Under the name of Rhytis paradoxa, Mayer (1839, Analect. $f$. vergl. Anat., Bomn, ii, 67) described a remarkable object, ten feet or more in length, saicl to have been passed [per anum (?)] by a eow. It is described as unsegmented and having a mouth, an anus and an alimentary eanal, but no other organs were made out. Mayer considered it to be a worm elosely related to the Nemathelminthi (including the Nematoidea and Acanthocephala of Rudolphi), but placed it in a separate "Order," Rhytelminthi. Aecording to Tschudi, Miescher and Nordmann (1839, Arch. f. Anat., Phys. u. wiss. Med., Berlin, 220), the object described by Mayer was not a parasitic worm at all.

13. Sclerotrichum Rudolphi, 1819.

Syn. Mastigodes de Blainville, 1828, nec Zeder, 1800.

Body elongate, stiff, composed of two portions, of which the anterior is very slender, ending anteriorly in a dise bordered with fifteen reeurved spines, in the centre of which is the mouth. The posterior portion of the body is stont and bears a series of moniliform swellings at its more anterior end. 
Hab. Stomach of a Reptile (Pseudopus).

Genotype: S. [Tacnia] spirillum (Pallas, 1781).

Pallas, 17S1, N. nord. Beytr. z. phys. u. geogr. Erd.-u. Völkerbeschr., ete., St. Petersburg \& Leipzig, i, 111 ; Rudolphi, 1809, Entozoorum . . Historia Naturalis, ii (1), 98; 1819 , Entozoorum Symopsis, 227; de Blainville, 1828, Dict. Sci.nat., Paris \& Strasburg, lii, 5:9; Nordmam, in Lamarek, 1840, Hist. nat. des. Anim. sans Vert., Paris, 660; Dujardin, 1845, Hist. nat. des Helminthes, Paris, 40.

This worm, if indeed it be a worm at all, appears possibly to have some affinity with the Trichinellidae, and may be a member of the subfamily Trieburinae. It seems, however, extremely cloubtful whether it is a Nematode. Rudolphi (1809) mentions its eurious rigidity and compares its eonsisteney with that of horm or of the chitin of insects. Nothing is known of the internal anatomy, and we do not feel justified in referring the genus to a definite systematie position.

14. Spherurus Rafinesque, 1815.

This is a nomen nudum, the genus being proposed for the reeeption of speeies of Ascaris (sens. lat.), but no speeies being named.

Rafinesque, 1815, Analyse de la Nature, Palermo, 151.

\section{Trachynema Cobb, 1920 (?).}

We have been unable to find any reference to this name exeept that of Cobb (1920, Contr. Sci. Nematol., ix, 250), where the oesophagus of Xenolaimus is compared with that of "Trachynema." No speeies is mentioned, and the name appears to be a nomen nudum.

\section{Vetteria Jägerskiöld, 1915 .}

We have been unable to trace the original referenee to this genus. According to Micoletzky (1922, Arch.f. Naturg., Abt. A, lxxxvii, 120) it has a single speeies, $V$. robusta, which is a nomen nudum.

17. Vibrio Miiller, 1773.

This genus included not only Nematodes but several Protozoa. The genotype is, according to Stiles \& Hassall, very doubtful. The name is a partial synonym of Anguillula and possibly of other genera.

Müller, 1773, Vermium terrestrium . . Historia, i (1), 39.

The following names also oceur in the literature of the Nematoda, but appear to have been applied to objeets that cannot be reeognized as Nematodes:- 
18. Dyacanthos Stiebel, 1817.

19. Fictitium Diesing, 1851 .

20. Furia Linnaeus, 1758.

\section{COLLECTIVE NAMES.}

The following names, in addition to those already mentioned elsewhere, have been proposed as eollective groups, ehiefly for larval Nematodes, and are without generic status or genotype :-

1. Agamofilaria Stiles, 1907.

2. Agamonema Diesing, 1851.

3. Agamonematodum Diesing, 1861.

4. Agamospirura Henry \& Sisoff, 1913.

5. Capsularia Zeder, 1800.

6. Dubium Rudolphi, 1819.

7. Filocapsularia Deslongehamps, 1824.

8. Helmins Sehlotthauber, 1860.

9. Merinthoidum Kraemer, 1853.

10. Nematodum Diesing, 1861 .

11. Nematoideum Diesing, 1851.

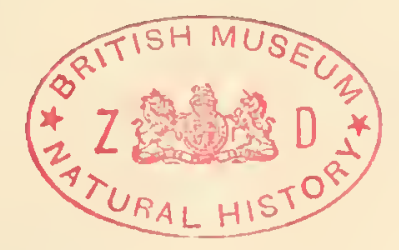





\section{INDEX}

[Synonyms in italics. Numbers in clarendon type refer to the main account.] Abreviata Travassos. Vide Physaloptera . . . 222 Acanthoeheilonema Cobbold . . . . . 196, 197 Acanthoeheilus Molin . . . . . . 9 Acanthonchus Cobb. Vide Desmodora . . . . 129 Acanthopharynx Marion. Vide Chromadora . . . 126 Acanthophorus v. Linstow. Vicle Tropisurus . . . 220 Acheilostoma Leiper . . . . . . . 173 Achromadora Cobb. Vidle Cyatholaimus . . . . 125 Acmaeolaimus Filipjev . . . . . . . 89 Acoma Steiner . . . . . . . 97 Acontiolaimus Filipjev. Vide Camacolaimus . . . 49 Aerobeles v. Linstow (subgen.). Vide Ceplaalobus . . 40 Actinolaimus Cobb. Vide Dorylaimus . . . 70,71 Aetinonema Cobb $\quad . \quad$. $\quad . \quad$. . 144 Acuaria Bremser . . . . . . . . 217 Acuaria (subgen.) Railliet, Henry \& Sisoff. Vide Aeuaria 217, 218 ACUARIINAE . Adoncholaimus Filipjev. Vide Oncholaimus 110 11 Aegialolaimus de Man . . . . . . 94 Africana Travassos . . . . . 14 Agamermis Cobb, Steiner \& Christie. Vide Mermis : $\quad 64$ Agamofilaria Stiles Agamomermis Stiles. Agamonema Diesing Agamonematodum Diesing Agamonematoideum Diesing Agamospirura Henry \& Sisoff . Agehylostoma Dubini. Vide Aneylostom Agriostominae Agriostomum Railliet Alaimella Cobb Alaimonema Cobb Alaimidae Alaimus de Man Alfortia Railliet (subgen.). Vide Strongylus : $: \quad . \quad 151$ Allantonema Leuckart . . . . . . 4 46, 47 Allodapa Diesing. Vide Subulura . . . . . 14,15 Alloionema Schneider. Vide Leptodera . . . . 60 Allomonhystera Micoletzky. Vide Monhystera . . . 80 Amblyonema v. Linstow . . . . . . 20 Amblyura Ehrenberg . : . . . : : 242

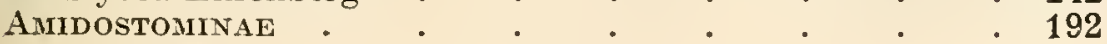


Amidostomum Railliet \& Henry

Amira Lano . . . $\quad 159$

Amphibiophilus Striabin : : : • : . 193

Amphispira Cobb. Vido Desmodora : . . . 129

Amphistemus Mlarion. Vide Eurystomina . . . 115

Amplicaecum Baylis . . . . . . 8

Amularia Brera." Vide Setaria . . . . . 200

Ananconus Railliet \& Henry. Vide Cosmocerea . . 30

Anatonehus Cobls (subgen.). Vide Mononehus . . 117

Anaxonchium Cobb . . . . . . 116

Anchilocephali Brera. Vide Setaria . . . . 200

Aneylostoma Dubini . . . . . . 166, 167

AnCylostomidae. . . . . . . . 166

Ancylostominae . . . . . . . 166, 168

Aneyracanthopsis Diesing . . . . . 234, 235

Ancyracanthus Diesing . . . . 7, 234, 235

Angiostoma Dujardin. Vide Rhabditis, Rhabdias - $\quad 36,37$

Anguillina Hammerschmidt . . . . . . 243

Anguillula Ehrenberg . . . . . . 38, 110

Anguillulina Gervais \& van Beneden . . . 65,66,67

Anguillulinae . . . . . . . 109,110

ANGUtLlulinidae . . . . . . . 36,65

Anguillulintisae. . . . . . . 65

Anguina Seopoli. Vide Anguillulina . . . . 65

Angustieaecum baylis . . . . . . . 8

Antsatimae . . . . . . . 4, 4,10

Anisakis Dujardin . . . . . . . . 5,7

Anomala Travassos. Vide Tanqua. . . . . 233

Anoncholaimus Cobb . . . . . . . 132

Anonchus Cobb . . . . . . . . . 87

Anoplostoma Biitschli : . . . . . . . 77

Anoplostrongylus Boulenger : . . . . . . 186

Antholaimus Cobb. Vide Dorylaimus : . . 70,71

Anthonema Cobb. Vide Plectus . . . . . 56

Anthraconema zur Strassen. Vide Siphonolaimus . . 48

Anthuris Rudolphi. Vide Acnaria . . . . . 217

Anticoma Bastian. . . 93

Anticyathus Cobb. . . . . . . . 88

Anticyclus Colob. . . . . . . . . 131

Antomicron Cobb. . . . . . . 62

Aorurus Leidy . . . . . . . . 26, 27

Aphanolaimus de Man . . . . . . . 94

Aphelenchoides Fiseher . . . . . . 243

A phelenchulus Cobb. Vide Anguillulina . . . . 66

Aphelenchus Bastian . . . . . . 67

Aphelenchus Micoletzky (subgen.). Vide Aphelenehus . 67

A plecta Railliet \& Henry. Vide Aplectana . . . 30

Aplectana Railliet \& Henry . . . . . . 30

Aplectus Cobb . . . . . . . . 56

Apodontium Cobb . . . . . . . . 141

Aponchium Cobl . . . . . . . . 119

Aprocta v. Linstow . . . . . . . . 205

AProctinae. . . . . . 205

Aproctonema Kéilin. Vide Mermis . . . 65

Araeolaimoides de Man (subgen.). Vide Áraeolaimus : 87 
Araeolaimus de Man

Archionchus Cobb. Vide Diphtherophora

Arduenna Railliet \& Henry . . . . . . 214

ARDUENNINAE

214

ASCARIDAE:

Ascaridia Dujardin

Ascaridinae.

AsCARINAE

Ascaris V. Linstow

ASCAROIDEA.

Ascaroides Barthélemy. Vide Rhabditis .

Ascarophis van Beneden

Ascarops van Beneden

Ascaropsis Porrer \& Sedgwick. Vide Ascarophis Ascolaimus Ditlevsen

Asconema Leuckart. Vicle Sphaerularia .

Asifia Lane. Vide Clıoniangium

Aspidocephalus Diesing. Vide Aspidodera

Aspidadera Railliet \& Henry .

Astomum Schlotthauber. Vicle Tropisurus

Asymmetrella Cobb

12

12

1

1

1,36

36

235

229

235

84

47

153

12

12

220

132

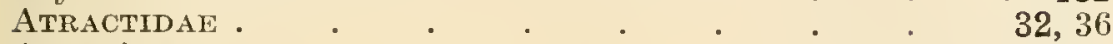

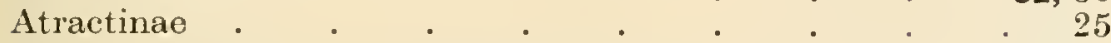

Atractis Dujardin . . . . . . . 33

Atractonema Leuckart. Vide Sphaerularia . . $\quad 47,48$

Atylenchus Cobb. Vide Anguillulina . . . . 65

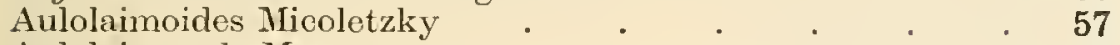

Aulolaimus de Man . . . . . . . 51

Austronema Cobb. Vide Mionliystera : : : : 80

Autoplectus Balsamo-Crivelli. Vide Mermis : $: \quad 65$

Axonchium Cobb. Vide Dorylaimus . : : $: 70$

Axonolainus de Man . . . . . . . 83

Bastiania de Ma11 . . . . . . . 95

Bathmostonum Railliet \& Henry . . . . . 173

Bathylaimus Cobb . . . . $\quad 82$

Bathylaimus Daday. Vicle Psendobathylaimus . . 120

Bathylaimus Ditlersen. Vide Ascolaimus . . . 84

Bathymermis Daclay. Vicle Mermis . . . . 64

Belascaris Leiper. Vide Toxocara . . . . . 2,3

Blattophila Cobb. . . . . . 44

Bogdanowia Zograf. Vide Bunonema . . . . 58

Bolbella Cobb . . . . . . . . 114

Bolbinium $\mathrm{Cobb}$ • . . . . . . . 996

Bolbolaimus Cobb $\quad$. $\quad$. $\quad$. $\quad$. 128

Bolbonema Cobb . $\quad . \quad$. $\quad . \quad$. $\quad .57$

Bourgelatia Railliet \& Henry . . . . . . 160

Brachyclonus Railliet \& Henry . . . . . . 169

Brachynema Cobb . . . . . . 74

Bradynema zur Strassen. Vide Allantonema : 46,47

Buddenbrockia Schröder . . . . . . 243

Buissonia Neveu-Lemaire. Vide Pteridopharynx : : 158

Bulbodacnitis Lane. Vide Cucullanus . . . . 231

Bunonema Jägerskiöld . . . . . . . . 58

BUNONEMINAE . . . . . 57 
Bunostomum Railliet

Bustomum Lane. Vide Bunostomum

Caconema Cobb. Vide Heterodera .

Calodium Dujardin. Vide Capjllaria

Calyptronema Marion

Camacolaimus de Man . . . . . . . . . 49

Camallanidae . . . . . . . . . 230

Camallanicles Baylis \& Daubney . . . . . $\quad 230$

Camallanus Railliet \& Henry. . . . . . 230

Campydora Cobb . . . . . . . . . 71

Campylaimus Cobb . . . . . . . . . 999

Capillaria Zeder . . . . . . . . . . . 238

Capsularia Zoder . . . . . . . . . . 255

Carnoya Gilson . . . . . . . . . 31

Catalaimus Cobb . . . . . . . . . 137

Catanema Cobb . . . . . . . . 120

Cephalacanthus Diesing. Vide Protospirura, Physocephalus 211 ,

Ceplialobellus Cobb

215,229

Cephalobium Cobb

Cephalobus Bastian

Cephalonema Cobb.

Vicle Ironus :

Cephalonema Pierantoni. Vide Pierantonia . . . 24 I

Cephalostrongylus Irwin-Smith. Vido Ornithostrongylus . 183

Ceramonema Cobb

Ceratospira Sehneider . . . . . . . 225

Ceylaneylostoma Lane. Vide Aneylostoma . . . . 167

Chabertia Railliet \& Henry . . . . . . 164

Chaetosoma Claparède . . . . . . . 106

Chamtosomatidat . . . . . . . . . 106

Chambersiella Cobb . . . . . . . . 42

Chaolaimus Cobb. Vide Diphtherophora . . . 73

Chaos Linnaeus . . . . . . . 251

Characostomum Railliet. Vide Globocephalus . . . 168

Cheilospirura Diesing (subgen.). Vicle Acuaria . . 218

Cheiracanthus Diesing. Vido Gnathostoma. . . . 232

Cheironehus Cobb. . . . . . . . . 148

Chevreuxia Seurat . . . . . . $\quad 219$

Chitinoaphelenchus Micoletzky. Vide Aplielenchus . $\quad 67$

Chitinotylenchus Mieoletzky. Vicle Anguillulina . . 66

Chlamydonema Noordhoek Hegt. Vide Physaloptera . 222.

Choanolaimus de Man . . . . $\quad 77$

Choerostrongylus Gedoelst . . . . . 176

Choniangium Railliet, Henry \& Bauche . . . . . 153

Choniolaimus Ditlersen . . . . . . 138

Choronema Cobb . . . . . . . 244

Chromadora Bastian $\quad$. $\quad$. 113, 114, 126, 127, 128, 138

Chromadorella Filipjev. Vide Chromadora . . . 126

Chromadorina Filipjev. Vide Chromadora . . . I26

Chromadorinae . . . . . 109, 110

Chromadorissa Filipjev. Vide Chromadora . . . 126

Chromadorita Filipjev. Vide Chromadora . . . 126

Chromadoropsis Filipjev. Vide Desmodora . . . 129

Chromagaster Cobb . . . . . . . 49 
Chromaspira Filipjev

Chromaspirina Filipjev. Vide Chromaspira • 122

Chronogaster Cobb

Vide Desnodora

Citellinema Hall

190,191

Cloacina v. Linstow

162

Cloeoasearis Baylis

Cobbia de Man

Cobbionema Filipjev

Cobboldia Leiper. Vide Cobboldina

Cobboldina Leiper

Cochlus Zeder. Vide Goezia

Codiostomum Railliet \& Henry

Coinonema Cobb

Colpurella Cobb

Comesoma Bastian

Conocephalus Diesing. Vide Anisakis

6,7

124,125

Conolaimus Filipjev. Vide Axonolaimus .

Conoweberia Ilıle (subgen.). Vide Oesophagostomum

Contortospiculum Skrjabin. Vide Dicheilonema

Contracaecum Railliet \& Henry

Cooperia Ransom

Cophonehus Cobb

Coronilla van Beneden. Vide Proleptus

Cosmocephalus Molin (subgen.). Vide Acuaria

Cosmoeerca Diesing

Cosmocercinat

Cothonolaimus Ditlevsen

Craspedonema Richters .

Crassicauda Leiper \& Atkinson

Crassisoma Alessandrini. Vicle Globocephalus .

Craterostomum Boulenger

Crenosoma Molin

Cricolaimus Southern

Criconema Hofmänner \& Menzel. Vide Hoplolaimus

Crino Lamarck. Vide Setaria

Crinola Rafinesque. Vide Crinon

Crinon Chabert. Vide Setaria

Croconema Cobb

Crossocephalus Railliet

Crossophorinae

Crossophorus Hemprich \& Ehrenberg

Cruzia Travassos

Cruzidae

Cruzinao

Cryptonchus Cobb

Crystallonema Cobb

Ctenocephalus v. Linstow. Vide Tanqua .

Cucullanidae

Cucullanus Müller .

Cucullanus auett., nec Miiller. Vide Camallanus

Cyartonema Cobb.

Cyatholaimus Bastian

Cyathostoma E. Blanchard 
Cyathostomum Looss. Vide Trichonema . . . . 154 Cyathostomum Molin. Vide 'Irichonema . . . . . 154 Cylichnostomum Looss. Vide Trichonema . . . . 154 Cylicocereus Thle (subgen.). Vide Trichonema . . . 156 Cylicocyclus Ihle (subgen.). Vide Trichonema . . . 156 Cylicodontophorus Ihle (subgen.). Vide Trichonema $\quad 156$ Cylicolaimus de Man . . . . . . . 121 Cylicospirura Vevers . . . . 216 Cylicostephanus Ihle (subgen.). Tide Trichonema . . 155 Cylicostomum Ihle (subgen.). Vide Trichonema . . 155 Cylicostomum Raillict. Vide Trichonema . . . 154 CylindrolaiminaE . . . . . . . 48 Cylindrolaimus de Man . . . . . . . . . 48 Cylinłropharynx Leiper . . . . . . . 161 Cynura Cobb . . . . . . . . 52 Cymea Seurat. Vide Habronema . . . . . 211,212 Cyrtosomum Gedoelst . . . . . . . 34 Cystidicola Fischer . . . . . . . 225 Cystocephalus Railliet. Vide Globocephalus . . . . 169 Cystoojsis Wagner . . . . . . . 244 Cytolaiminn Cobb . . . . . . . . 103

Dacnitis Dujardin. Vide Cucullanus . . . 231, 232 Dacnitoides Ward \& Magath . . . . . . . 231 Dactylaimus Cobb . . . . . 84 Dadayia Micoletzky. Vide Pseudobathylaimus . . 120 Dagda Southern . . . . .

Daptonema Colbb.

Dasynema Cobb

Decrusia Lane (subgen.). Vide Strongyhis Delafondia Railliet (subgen.). Vide Strongylus Deletrocephalus Diesing

Demania Southern. Vide Rhabdodemania

Demania Steiner. Vide Demaniella.

Demaniella Steiner

Demonema Cobb. Vide Enoplus .

Deontolaimus de Man

Deontostoma Filipjev. Vide Thoracostoma

Deraiophoronema Romanovitelı. Vido Setaria.

Dermatolaimus Steiner.

Dermatoxys Schneider

Dermofilaria Rivolta. Vicle Habronema.

Desmidocerca Skrjabin .

Desmodora de Man

DESMODORINAE

Desmolaimus de Man

DesmoscolecidaE

Desmoscolex Claparècle

DiapitanocephaLidaE

Diaphanocephalus Diesing

Dicelis Dujaudin

Dicentrocephalus Diesing. "Vicle Dikèntrocephalizs Diceras Ruclolphi. Tide Ditrachyceros

Dicheilunema Diesing

Dichelyne Jägershiöld. Vide Cucullanus .

Dictyocaulus Railliet \& Henry 
Didelta Cobb

Digitonchus Cobb

Dignathonema Filipjev • • • .

Dikentrocephalus Wedl . . . . . . . . 244

Dintheria de Man . . . . . . . . 81

Dioctophyme Collet-Nleygret . . . • . . 236

DIOCTOPH YMIDAE • • • • . • • . . 236

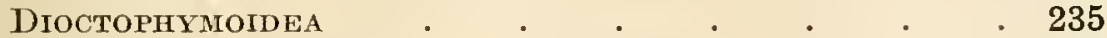

Dioclontolaimus Southern _. . . . . . . 142

Dionyx Perrier. Vide Synoecnema . . . . . . 242

Dipeltis Cobb. Vide Diplopeltis . . . . . 103

Dipetalonema Diesing . . . . . . . . . 196

Diphtherophora de Man . . . . . . 73

Diphtherophorinae. Vide Anguillulinidae • . $\quad$. 65

Diplasia von Holten . . . . . . . . 251

Diplogaster M. Schultze . . . . . . . $\quad 41$

Diplogasterinae. Vide Oncholaimidae . . . 109,110

Diplogasteroides de Man. Vide Diplogaster . . . 41

Diplohystera Onorato-de Cillis . . . $\quad$. $\quad .89$

Diplolaimus v. Linstow . • . • • . . 245

Diploodon Molin. Vide Aneylostoma . . . . . 166

Diplopeltis Cobb . $. \quad . \quad . \quad . \quad . \quad . \quad .103$

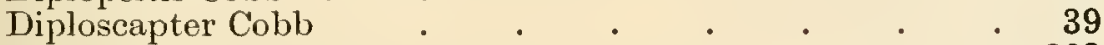

Diplotriaena Railliet \& Henry . . . . . . 203

DIPLOTRIAENINAE . . . 203

Dirhynchus Rudolphi. Vide Ditrachyceros . . . 250

Dirofilaria Railliet \& Henry . . . . . . . 195

Discolaimus Cobb. Vide Dorylaimus . . . . 70

Disconema Filipjev $\quad . \quad$. . . . . . . 105

Discophora Villot . . . . . . . . . . 136

Discophorus Mehlis . . . . . . . . . 252

Dispharagus Dujardin. Vide Acuaria . . . . 217

Dispharynx Railliet, Henry \& Sisoff (subgen.). Vicle Acuaria 218

Ditrachyceras Sultzer. Vide Ditrachyceros . . . 252

Ditrachyceros Hermann . • . • • . 252

Ditrachycerosoma Brera. Vide Ditrachyceros . . . 252

Dochmius Dujardis. Vide Uncinaria . . . . 172

Dochmoides Cameron. Vide Uncinaria . . . . 172

Dolichodorus Cobb. Vide Anguillulina . . . . 66

Dolicholaimus de Man . . . . . . . 143

Dorylaimellus Cobb. Vide Dorylaimus . . . . 70

DORYLAIMITNAE . . . . . . . 65,70

Dorylaimopsis Ditlevsen $\quad . \quad$. $\quad . \quad$. $\quad$. 139

Dorylaimus Dujardin . . . . . . . 65, 70,71

Doryllium Cobb. Vide Dorylaimus . . . . 70

Draconema Cobb . . . . . . . 106

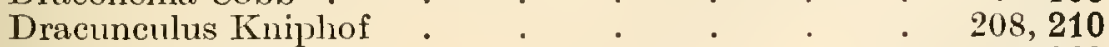

Drilonema Pierantoni : . . . . . . 240

DRILONEMIDAE • . . . . . . . . 240

Dubium Rudolphi . . . . . . . . . 255

Dujardinia Gedoelst . . . . . . . . 7

Dyacanthos Stiebel $\quad . \quad+\quad . \quad . \quad . \quad . \quad . \quad 255$

Echinocephalus Molin . . • . . • . 233

Echinonema v. Linstow . . . . . . . 228 
Eehinuria Solovier (subgen.). Vide Acuaria .

Eephyadophora de Man .

Elaphoeephalus Molin . . . . . . . . . 235

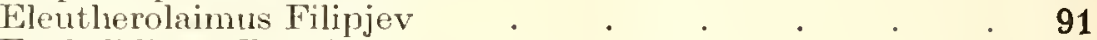

Enelielidium Ehrenberg . . . . . . . . . . 93

Endolaimus Filipjer. Vide Chromadora . . . . 126

Enoplinae . . . . . . . . 109, 144

Enoploides Saveler. Tide Enoplus . . . . . 144, 145

Enoplolaimus de Man. Vide Enoplus . . . . 144, 145

Enoplostoma Marion . . . . . . . . . 149

Enoplus Dujardin . . . . . . 144, 145, 147

Enoplus Eberth. Vide Leptosomatum . . . . . 97

Enterobius Leach . . . . . . . 23

Epomidiostomum Skrjabin . . . . . . . $\quad$. 192

Equinurbia Lane . . . . . . . 153

Ethmolaimus de Man. Vide Chromadora . . . $\quad 126$

Eubostrichus Greeff . . . . . . . . 245

Eucamptus Dujardin . . . . . . . 206, 207

Euchromadora de IIan. Vide Chromadora . . 126,127

Eucoleus Dujardin. Vide Capillaria . . . . 238

Eucyathostomum Molin . . . . . . . 161

Eudesmoscolex Steiner . . . . . . . . . 108

Eufilaria Seurat . . . . . . . . . 205, 206

Eulinhomoeus de Man (subgen.). Vide Linhomoeus . . 124

Eumermis Daday. Vide Mermis . . . . 65

Eumonodontus Pailliet \& Henry. Vide Nonodontus . $\quad 171$

Eurystoma Marion. Vide Eurystomina . . . . . 115

Eurystomina Filipjev . . . . . . . . 115

Eustoma van Beneden . . . . . . . . . . . . $\quad$. 246

Eustrongylides Jägerskiöld : • • • • • • • • • $\quad$ • 236

Eustrongylus Diesing. Tide Dioctophyme . . . . 236

Eutelolaimus de Man. Vide Antomieron . . . . $\quad 62$

Eutylenchus Cobb. Tide Anguillulina . . . . 65

Eransia Railliet \& Henry. Vide Quilonia . . . 159

Falcaustra Lane. Vide Spironoura . . . . . 17

Fiaera Southern . . . . . . . . 146, 147

Fictitimm Diesing . . . . . . . . . 255

Filaria IIüller . . . . . . . . . . . 194, 195

Filariddat . . . . . . . . . . 194

Filarifnae . . . . . . . . . . . 194

Filarina Hammersehmilt . . . . . . . . 246

Filarioidea $\quad . \quad$. . . . . . . . . 193

Filaroides van Beneden. . . . . . . . 178

Filocapsularia Deslongehamps . . . . . . . 255

Fimbria Cobb. Vide Fimbrilla . . . . . $\quad$. 88

Fimbilla Cobb . . . . . . . . . . 88

Fissula Lamarek. Vide Crstidicola . . . . 225

Florencioia Travassos. Vide Spironoura . . . . 17

Folevella Seurat . . . . . . . . 198

Fuchsin Nicoletzky. Vide Diplogaster : : : . 41

Furia Linnaeus . . . . . 255

Fusarella Senrat. Vide Enterobius . . . . 23

Fusaria Zeder. Vide Ascaris . . . . . . . . 1 
Gaigeria Railliet \& Henry

Galeiceps Railliet .

Galoncus Railliet

6,7

167

Gammanema Cobb

Ganguleterakis Lane. Vide Heterakis

113

Gastromermis Micoletzky. Vide Nermis . . . . $\quad 65$

Gilsonia Gedoelst. Vide Hadjelia

Gireterakis Lane. Vide Heterakis

Globocephalus Molin

Gnathostoma Owen

Gathiostomidae .

Gathostominae .

Goezia Zeder

Goeziinae

Gongylonema Molin

Gonionchus Cobb .

Grammocephalus Railliet \& Henry

Grammophora Gedoelst. Vide Katanga

Graphidioides Cameron .

Graphidium Railliet \& Henry .

Graphonema Cobb. Vide Chromadora

Greeffiella Cobb

Gyalocephalus Looss

Gymnolaimus Cobb

Habronema Diesing

$211,212,214$

Hadjelia Seurat

Haematozoon Leisering. Vide Haemostrongylus

Haemonchus Cobb

Haemostrongylus Railliet \& Henry :

Halalaimus de Man

Halanonchus Cobb

Halaphanolaimus Southern : $: \quad . \quad \cdot \quad \cdot 62$

Halichoanolaimus de Man. Vide Spilophora : : 113,147

Halinema Cobb . . . . . . . . 53

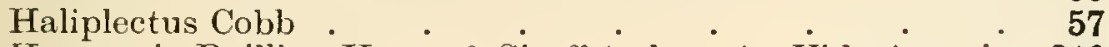

Hamannia Railliet, Henry \& Sisoff (subgen.). Vide Acuaria 219

Hamatospiculum Skrjabin

198

Hamularia Trentler. Vide Setaria . . . . . 200

Haplacis Railliet \& Henry . . . . . . . 29

Haplonema Ward \& Magath . : . : . : . 235

Hartertia Seurat . . . . . . . . 212

Hastospiculum Skrjabin . . . . . . 204

Hedruris Nitzsch . . . . . . . . . 213

Helalaimus Onorato-de Cillis : $\quad . \quad$ : $\quad .99$

Heliconema Travassos . . . . . . 222

Helicothrix Galeb. Vide Pseudonymus . . . . 27

HELIGMTOSOMINAE . . . . . . . . 187

Heligmosomoides Hall . . . . . . 187, 188

Heligmosomum Railliet \& Henry . . . . 187, 191

Heligmostrongylus Travassos . . . . . . . . 188

Heligmus Dujardin . . . . . . . 10

Helmins Schlotthauber . . . . . . . 255

Helminthus Dunglison. Vide Setaria . . . . 200

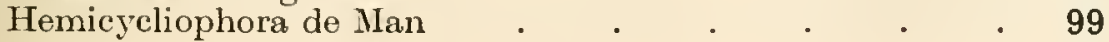


Hemipsilus Quatrefages. Vide Thoraeostoma .

Henryella Neveu-Lemaire. Vide Pteridopharynx

Hepaticola Hall

Heteratidate

HETERAKINAE

Heteralis Dujardin

Heterobolbus Railliet. Vide Heterodera

$11,12,19$

11,14

Heteroeephalus Narion .

67,68

148,149

Heterocheilinae

Heterocheilus Diesing. Vide Lobocephalus

5,10

Heterodera Sehmiclt

Heteroura v. Siebold. Vide Hedruris

213

Heteroxynema Hall

15

Hetlı Cobb

Hexametra Travassos. Vide Polydelphis:

36,45

Hexodontostomum Ihle. Vide Poteriostomum .

Histioeephalus Diesing. Vide Proleptus .

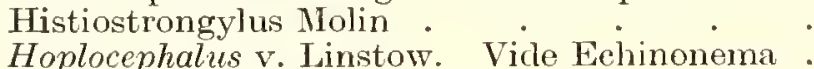

Hoplodontophorus Turner . . .

Hoplolaimus Daday

Howardula Cobb. Vide Allantonema

Hyalaimus Cobb. .

Hydromermis Corti. Vide Mermis : :

Hyostrongylus Hall • • • • . 182

Hypodontolaimus de Man. Vide Spilophora : . i13,114

Hypostomum Stewart. Vide Oesophagostomum . . 163

Hysteraerum Railliet \& Henry (subgen.). Vide Oesophagostomum

Hysterothylaeium Ward \& Magath. Vide Raphiclascaris

Hystrichis Dujardin

Hystrignathus Leidy

Iehthyonema Diesing. Vide Plilometra . . . . 208

Iehthyospirura Skrjabin. Vide Rhabdochona: : : 224

Icosiella Semat . . . . . 200

Illium Cobb . . . . . . 53

Impalaia Monnig . . . . . . . . . . 190

Ionema Cobb . . . . . . . 99

Iota Cobb. Vide Hoplolainus $\quad$. $\quad$. $\quad$. $\quad$. $\quad 69$

Iotadorus Cobb . . . . . . . . . . 133

Iotalaimus Cobb . . . . . . 994

Jotonehium Cobb. Vide Anguillulina . . . $\quad 66$

Iotonehus Cobb (subgen.). Vide Mononehus . . . 117

Ironella Cobl $. \quad . \quad . \quad . \quad . \quad 141$

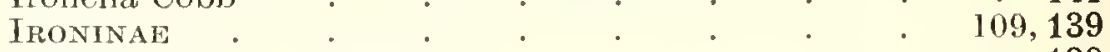

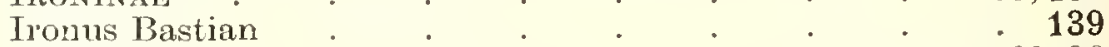

Isakidae $\quad \circ \quad \therefore \quad$. $\quad . \quad 21,36$

Isakis Lespès $\quad . \quad \therefore \quad$. $\quad$. $\quad 21,30,32,36$

Isolaimium Cobb. . . . . . . . 51

Isonehus Cobb . . . . . . . . $\quad .69$

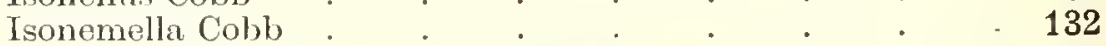

Jägershiöldia Filipjev. Vide Thoracostoma . . 134, 135

Kalicephalus Molin . . . . . . 174, 175

Katanga Yorke \& Maplestono $\quad . \quad$. $\quad . \quad$. 199 
Kathlania Lane

KATHLANIIDAF

Kathleena Leiper \& Atkinson. Vide Contraeaeeum

Khalitia Neveu-Lemaire. Vide Amira . .

Kiluluma Skrjabin

Krampia Ditlevsen

Krikonema Hofmänner \& Nenzel. $\dot{V}$ ide Hoplolaimus

Labiduris Sehneider

Labyrinthostoma Cobb

Lagoehilasearis Leiper

Laimella Cobb

Laphyctes Dujardin. Vide Rictularia

Lasiomitus Marion

Laxonema Cobb

Laxus Cobb

Lecanocephalus Diesing. 'Vido Goezia

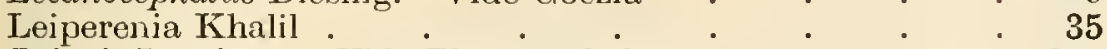

Leiuris Lenckart. Vide Physoeephalus : $\quad$ : $\quad$. 215

Lemdana Seurat

Lepidonema Cobb .

36,45

Leptodera Dujardin

Leptogastrella Cobb

Leptolaimus de Man

Leptonchus Cobb. Vide Triehodorus

Leptonemella Cobb

Leptosoma Travassos. Vide Physaloptera

Leptosomatides Filipjev. Vide Thoraeostoma

Leptosomatum Bastian .

Lepturis Schlotthauber. Vide Oxyuris

Libyostrongylus Lane. Vide Triehostrongylus

Limnomermis Daday. Vide Mermis

Lineola Kölliker. Vide Enoplus

Linhomoella Cobb .

Linhomoeus Bastian

Liniscus Dujardin. Vide Capillaria

Liorhynehus Rudolphi
Lissonema v. Linstow. Vide Aproeta

Litinium Cobb

Litomosa Yorke \& Maplestono

Litonema Cobb

Litosoma van Beneden. Vide Litomosa.

Litotes Cobb

Loa Stiles

Lobocephalus Diesing

Lombricoides Mérat. Vide Ascaris

Longidorus Micoletzky. Vido Dorylaimus

Lumbrieieola Friedländer

134,135

97,135

Macracis Gedoelst

Macrolaimus Ditlevsen. Vide Cothonolaimus

Macrolaimus Maupas

124

41,110

Macroposthonia de Man . . . . . . . . . $\quad$. 98

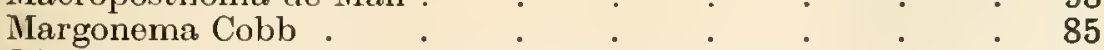

Marionella Cobb. Vide Eurystomina : : : : 115

Mastigodes de Blainville. Vide Sclerotrichum . : : 253 
Mastigodes Zerler. Vide Triehmis

Iastodex Steiner.

Mastophorus Diesing.

215,229

Maupasiella Senrat. Vicle Maupasina

Maupasina Seurat.

14,15

Meeistoeirrus Railliet \& Henry

185

Mehdiella Seurat. Vicle Tachygonetria

25,26

Meloidogyne Goeldi. Vide Heterollera

67

Memphisia Khalil. Vicle Ptericlopharynx

57,158

Merinthoidum Kraemer .

Mermis Dujardin

MERMITHIDAE

Mesodorus Cobb

Mesomermis Daday. Vide Mermis.

36,63

133

Mesonehium Cobb.

Mesonema Pierantoni. Vide Drilonema

240

Metachromadora Filipjev. Vicle Desmodora

129

Metalinhomoeus de Man

124

Metastrongylidae

Metastrongylus Molin

Mctoncholamms Filipjev. Vide Oneholaimus

175

Mieipsella Seurat

Microcephalus Romanoviteh. Vide Nematodirus

Mierofilaria Cobbold

Mierolaiminae

Mierolaimus de Man

Micromicron Cobb. Vide Desmodora

Mieropleura v. Linstow

Microtetrameres Travassos. Vide Tropisurus

Mitrephorus v. Linstow.

Molgolainus Ditlevsen.

Molineus Cameron

Monliystera Bastian

Monhystericles Baylis \& Daubney

110,111

202

185

- 208

109,110

122

129

208,209

220,221

. 246

100

184

$59,80,81,91$

Monhysterinae. Vide Trilobidae $\quad{ }^{\circ}$

Monhystrium Cobb

Monodontus Molin

Monodontus Molin, of Pansom etal. Virle Bunostomum 170, 171

Monohystera de Man. Vide Monhystera. . . 80

Monolrystrella Cobb

Mononehulus Cobb

112

Mononehus Bastian

Monopetalonema Diesing

Monoposthia cle Man

Multicaceum Baylis

Murshidia Iane

Myctolaimus Cobb

Myenehus Selıuberg \& Sehröder

Mylonehulus Cobb (subgen.). Vide Mononehus

Myolaimus Cobb

Myoryetes Ebertli.

Myzomimus Stiles. Vide Gongylonema 
Nannonchus Cobb. Vide Cyatholaimus

Nanonema Cobb. Vide Ironus

Necator Stiles

Necatorinae

Neetieonema Marion

Needhamia Carus.

Nema Leidy .

Nemanema Cobb

Nematevansia Ihle. Vicle Quilonia:

Nematodirus Ransom

Nematodum Diesing

Nematoideum Diesing

Nematospira Walton

Nematoxys Schneider. Vide Cosmoeerea, Apleetana .

Nemella Cobb

Nemonehus Cobb .

Neomermis v. Linstow. Vide Mermis

Neonchus Cobb. Vide Odontolaimus

Neurella Cobb

Nippostrongylus Lane

Notoehaetosoma Irwin-Sinitl

Nuada Southern

Nudora Cobb

Numidica Barreto .

Nygolaimus Cobb. Vide Dorylaimus

Obeliscoides Graybill

Obeliscus Graybill. Vide Obeliscoides

181

Occipitodontus Ortlepp. Vide Kalicephalus : : 174,175

Oehetoeephalus v. Linstow

- 223

Odontobius Roussel de Vauzème

Odontocricus Steiner. Vide Chromadora $\quad 126$

Odontogeton Allgén

30,32

129

Odontopharyngidae $: \cdot{ }^{\circ} \cdot{ }^{\circ} \cdot 109$

Odontopharynx de Man . . . . . . . . . 118

Odontophora Buitsehli . . . . . . . 140

Oesophagodontus Railliet \& Henry . . . . . 153

OESOPHAGOSTOMINAE . . . . . . 160, 163, 168

Oesophagostomum Molin

163,175

Ogma Southern. Vide Hoplolaimus

Oionehus Cobb . . . . . . . 118

Oistolaimus Ditlevsen . . . . . . . . 130

Oligomonohystera Mieoletzky (subgen.). Vide Tersehellingia $\mathbf{6 1}$

Ollulanus Leuckart . . . . • . . . 191

Omicronema Cobb . . . . . . . . 54

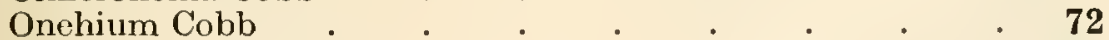

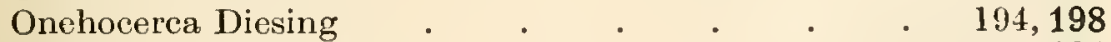

Onchocercinae Leiper . . • . . • • . 194

Oncholaimellus de Man . . . . . . . . 111

ONCHOLAIMIDAE $. \quad . \quad . \quad$. . . . 109

ONCHOLAIMINAE • . . . . . . 109,110

Oneholaimus Dujardin . $\quad$. $\quad$. $\quad$. $\quad$. $89,110,111$

Onehophora Krøyer . . . . . • • . 252

Onehulella $\mathrm{Cobb}$. $\quad$ • . . . . . . 72 
Onchulus Cobb. Vide Mononchus . . . . . 117

Oncophora Diesing. Vide Onchophora . . . . $\quad 252$

Onyx Cobb . . . . . . . . . 136

Ophiclasearis Baylis . . . . . . . $\quad$. 1

Ophiostoma Rudolphi. Vide Cystidicola . . . . 225

Ophiostomum Creplin. Vide Cystidicola . . . . $\quad 225$

Ophiostomum Creplin of Seurat. Vide Seuratum . . 231

Opistonema Pierantoni. Vide Drilonema . . . . . 240

Orneoascaris Skrjabin . . . . . . . . 4

Ornithostrongylıs Travassos . . . . . . . . 183

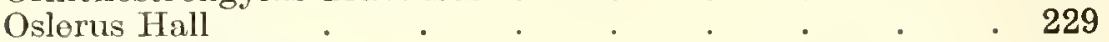

Ostertagia Ransom . . . . . . . . 182

Oswaldoeruzia Travassos $\quad . \quad$. $\quad . \quad . \quad . \quad . \quad 183$

Oxyasearis Travassos . . . . . . . . . $\quad$. 20

Orynema v. Linstow . . . . . . . . $\quad$. 14

OXYASCARIDAE . . . . . . . . 20

Oxysoma Schneider. Vide Oxysomatium, Kathlania, Cruzia 16,

18,31

Oxysomatinae

Oxysomatium Railliet \& Henry $\quad \cdot \quad \cdot \quad \cdot \quad \cdot \quad \cdot \quad \cdot \quad 31$

Oxyspirura v. Drasche . . . . . 224

Oxystoma Bütschli. Vide Oxystomina . . . . 97

Oxystomina nom. nov. . . . . . . 97

Oxyurias Stiles. Vide Enterobius . . . . . . 23

OXYURIDAE . . . . . . . . . $\quad 20,21$

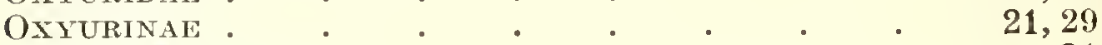

Oxyuris Ridolphi . . . . . . . . 21

Ozolaimus Dujardin . . . . . . . . 24

Papillosetaria Vevers. Vido Setaria . . . . 200

Parabronema Baylis . . . . . . . 212

Parachromadora Nicoletzky : • : : . 127,128

Paracis Railliet \& Henry. Vide Tachygonetria . . 25

Paraeyatholaimus Micoletzky. Vide Cyatholaimus . . 125

Paralinhomoeus de Man (subgen.). Vide Linhomoeus : 124

Paramernis v. Linstow. Vide Mermis . . . 64, 65

Paramonohystera Steiner. Vide Monhystera . . . 80

Paranisakis Baylis . . . . . 7

Paraphanolaimus Mienletzky . . . . . . 79

Paraphelenehus Micoletzky. Vide Apheleneluus • . 67

Paraquilonia Neveu-Lemaire. Vide Quilonia . . 159

Pararhabrlitis nom. nov. . . . 63

Parasabrtieria de Man. Vicle Comesoma . . . 124, 125

Parasitylenchus Micolotzky Vide Anguillulina • . 66

Paraspidodera Travassos . . . . . . 12

Paratrilobus Micoletzky . • • • . 76,77

Paratylenehus Mieoletzky. Vido Anguillulina . . . 66

Paroneholaimus Filipjev . . . . . . 111

Passalurus Dujardin . . . . . . . 28

Pelagonema Cobb. . . . . . . . 89

Peleeitus Railliet \& Henry . . . . . . 202

Pelodera Schneider. Vicle Rhabditis . . . . 36

Pelodytes Schneider. Vide Rhabditis . . . . 36

Penzancia de Man. Vide Monhystera . . . . 80

Pepsonema Cobb. Vide Mesonchium . . . . 140 
Peritrachelius Diesing. Vido Anisakis

Phaeelura Ehrenberg . . . . : : : 247

Phanoderma Bastian . . . . . . . 115

Phanoglene Fberth. Vide Leptnsomatum . . 97

Phanoglene Nordmann . . . . . . . 247

Pharetrolaimus do Man ․ . . . . . 137

Pharnerus Lenekart. Yride Stenurus . . . . 178

Pharyngodon Diesing . . . . . . . . 25

Pharyngodonidae . . . . . . . . 21

Pharyngonema Pierantoni . . . . . . . 241

Philometra Costa . . . . . . . . 208

Philometridae . . . . . . . . 208

Phlyctainophora Steiner . . . . , . 247

Physaloptera Rudolphi . . . . . . . 222

Physalopterinae $: \quad \cdot \quad \cdot \quad \cdot \quad \cdot \quad \cdot 222$

Physocephalus Diesing • . • • • . 215,229

Pierantonia nom. nov. . . . . . . . . 241

Piguris Sehlotthauber . . . . . . . 248

Platycoma Cobb . . . . . . . . 90

Plectoides de Man. Vide Plectus . . . . . 56

Pleetus Bastian . . . . . . . 56

Pleurorhynchus Rudolphi. Vide Cueullanus . . . $23 \mathrm{I}$

Pleurorinchus Nau. Vide Cueullanus . . . . 231

Pneumonema Johnston . . . . . • . 228

Politospieulum Skrjabin $\quad . \quad$. $\quad . \quad$. . . 200

Polydelphis Dujardin . . . . . . . . 2

Polygastrophora de Man . . . . . . . 114

Polylaimium $\mathrm{Cobb} \quad . \quad$. $\quad . \quad$. $\quad . \quad$. $\quad$. 83

Polysigma Cobb. Vide Chromadora . . . . . 126

Pomponema Cobb. Vide Cyatholaimus . . . . 125

Pontamonema v. Linstow . . . . . . . 253

Pontonema Leidy . $\quad . \quad$. $\quad$. $\quad$. $\quad$. $\quad$. $\quad 248$

Poroeoma Cobb . . . . . . . 101

Porrocaecum Railliet \& Henry . . . . . . . 6, 8

Potamonema Leidy . . . . . . . . . 248

Poteriostomum Quiel . . . . . . 156

Prionchulus Cobb (subgen.). Vide Mononchus : . II7

Prionoderma Rudolphi. Vide Goezia . . . . 9

Prionostemma Gendre. Vide Streptocara : . : 220

Prismatolaiminae. Vide Trilobidae . . . . 76

Prismatolaimus de Man . . . . . . . . 86

Proboseidea Cuvier . . . . . . . 253

Probstmayria Ransom . . . . . . . 19, 20

Proeamallanus Baylis . . . . . . . . 230

Proehaetosoma nom. nov. . . . . . . 107

Prochromadora Filipjev. Vide Chromadora . . . 126

Prodesmodora Mieoletzky. Vide Desmodora . . . 129

Proleptus Dujarchin . . • . . . . 223

Promononchus Micoletzky. Vide Mononehus . . . 117

Prooncholaimus Mieoletzky. Vide Oncholaimus 110,111

Prosphaerolaimus Filipjev . . . . . . 105

Prosthecosacter Dicsing. Vide Stenurus . . . . 178

Proteraerum Railliet \& Henry (subgen.). Vide Oesophagostomum . . . . . 164

Prothelmins v. Linstow . $\quad$. $\quad$. $\quad$. $\quad 248$ 
Protospirura Seurat

Protostrongylus Leiper.

Protozoophaga 'Travassos

Protrellus Cobb

Psoudalius Dujardin

Pseudancyracanthus Skrjabin. Vide Cystidicola, Rhabdochona

Pseudaspidodera Baylis \& Daubney

224,225

Pscudobathylaimus Filipjev

Pseudochromadora Daclay

Pseudoheteralis 'Travassos. Viclo Kathlania

Pseudolella Cobb

Pseudomermis de Man. Vide Mermis

Pseudonehus Cobb

Pseudonymus Diesing

Pscudorhabditis Perroncito. Vicle Strongyloides

Pseudorhabditis Szüts. Vide Pararhahditis

Pseudosclerostomum Quiel. Vide Oesophagodontus

Psilenchus de Man

Pteridopharynx Lano

Pterocephalus v. Linstow. Vicle Crossoceplalus

Pterygifer v. Linstow

Pterygodermatites Wedl. Vide Rictularia

Ptychocephalus Diesing. Vide Pseudonymus

Ptycholaimellus Cobb. Vicle Chromadora

Pycnolaimus Cobb. Vide Pleetus

Quadricoma Filipjev. Vide Desmoscolex .

107,108

Quilonia Lane

Raillietostrongylus Lane. Vide Globocephahus .

Ransomus Hall

Raphiclascaris Railliet \& Henry . . . . . . 5

Rhabdias Stiles \& Hassall

36,37

Rhabdiasidae

Rhabditidae

Rihabditinae

Rhabditis Dujardin

Rhabditolaimus Fuch.

Rhabdochona Railliet

Rhabdocoma Cobb

Rhabdodemania nom. nov. . . . . . 112

Rhabdogaster Metchnikov. Vide Prochaetosoma : 107

Rhabdolaimus de Man . . . . . . 43

Rhabdoncma Leuckart. Vide Rhabdias, Strongyloides . 37

Rhabdotoderma Marion . . . . . . . . 147

Rhadinema Cobb. . . 55

Rhigonema Cobb. Vide Isalsis . . . . . . $\quad 32$

Rhinema Cobb . . . . . . . . 130

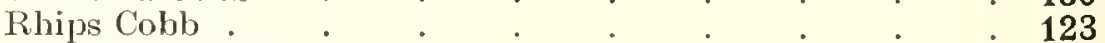

Rhynchonema Cobb . . . . . . . 55

Rhytis Maycr . . . . . . . . . 253

Richtersia Steiner. . . . . . . . . 109

Rictularia Frölich . . . . . . . . . 227

Rictularioides Hall . . . . . . . . 227 
Sabaticria de Rouville. Vide Comesoma .

Seaptrella Cobb

Schistodera Cobb.

Schistorophinae

Schistorophus Railliet

Schizocheilonema Diesing. Vide Tricheilonema

Sciadiocara Skrjabin

Sclerostoma Rudolphi. Vide Strongylus

Sclerostomum auctt. Vide Strongylus

Sclerotrichum Rudolphi .

Scolecophilus Baylis \& Daubney

Selachinema Cobb

Serradacnitis Lane. Vide Cucullanus

Serratospiculum Skrjabin

Serticeps Railliet

Setaria Viborg

Seuratia Skrjabiu (subgen.). Vide Acuaria

Seuratia Ditlevsen. Vide Seuratiella

Seuratiella Ditlevsen

Seuratum Hall

Simondsia Cobbold

231,232

Siphonolaimus de Man

Solenolaimus Cobb

48,49

Solenonema Diesing

Sonsinia Baylis \& Daubney. Vide Spinicauda

Spherurus Rafinesque

Spiliphera Bastian. Vide Spilophora

Spilipherella Filipjev. Vide Chromadora

Spilophora Bastian

Spilopharella Filipjev. Vide Chromadora

Spinicauda Travassos

Spinifer v. Linstow. Vide Mermis:

Spinitectus Fourment

Spira Bastian. Vide Spirina .

Spira do Man. Vide Araeolaimus

Spirina Filipjer

Spirocerca Railliet \& Henry :

Spironoura Leidy .

Spiroptera Rudolphi. Vide Acuaria

Spiropterina van Beneden. Vide Proleptus

SPIROXYINAE

Spiroxys Schneider

Spirura E. Blanchard

Spirura Diesing. Vide Spironoura

47,48

254

- 113

. 126

113,134

126

13

65

227

104

SPIRURIDAE

SPIRURINAE 
Squamanema Van Thiol- Vid Parabromema

Squarel. Vide Parabronema . 212

Steineria Filipjev. Vide Desmodora . . . . . 129

Steineria Micolctzk. Vide Monliystera . . . $\quad . \quad 80$

Stelmius Dujardin. Vide Cucullanus . . . . 231

Stenodes Dujardin . . . . . . . 250

Stenolaimus Marion . . . . . . . . $\quad$. 102

Stenurus Dujardin . . . . . . . 178

Stephanolaimus Ditlevsen . . . . . . 84

Stephanurinae . . . . . . . . 165

Stephanums Diesing . . . . . . . . 165

Stercoralis Tanaka. Vide Strongyloides . . . . $\quad 37$

Stilboncma Cobb . . . . . . 101

Stomachida Pereboom. Vide Ascaris . . . . . 1

Streptocara Railliet, Henry \& Sisoff . . . . 220

Streptogaster Cobb . . . . . . . . 606

Streptopharagus Blane . . . . . . . 216

Streptostoma Leidy. Vide Aorurus _ . . . $\quad 26,27$

Strongylacantha van Beneden . . . . . 168

STRONGYLIDAE . . . . . . . . 150

STRONGYLINAE . . . . . . . . . . . 150

STRONGYLOIDEA . . . . . . . . 150

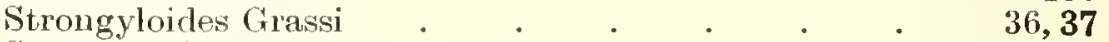

Strongyluris Mïllor . . . . . . . . 13

Strongylus Müller . . . . . . . . 150

Strongylus Railliet (subgen.). Vide Strongylus . . 151

Subulura Molin . . . . . . . . 14

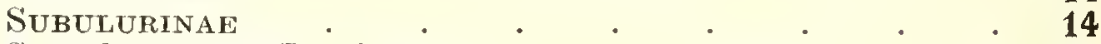

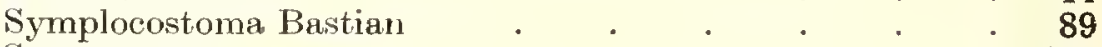

SYNGAMINAE $\quad . \quad$. $\quad . \quad . \quad . \quad . \quad 165$

Syngamus v. Siebold . . . . . . . 165

Syuhimantus Railliet, Henry \& Sisoff (subgen.). Vide Acuaria 218

Synodontium Cobb . . . . . . . 142

Symoecnema Magalhães . $\quad$. $\quad$. $\quad$. $\quad$. $\quad$. $\quad . \quad 242$

Synonchium Cobb. . . . . . . . . . 145

Synonchus Cobb . . . . . . . . . . $\quad$. 121

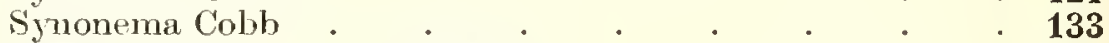

Symplecta Leidy. Vide Hedruris . . . . . 213

Synthetocaulus Railliet \& Henry . . . . 176

Syphacia Semrat . . . . . . . . . . 29

Syphaciella Monnig . . . . . . . . . . 31

Syphacimat . $\quad . \quad$. $\quad . \quad$. . . . . 21

Syringolaimus de Man . . . . . . . . $\quad$. 143

'Tachygonetria Wedl . . . . . . 25, 26

Tachyhodites Bastian. Vide Monhystera . . . . 80

Tanqua R. Blanchard . . . . . . . . 233

T'entacularia Zeder. Vide Setaria . . . . . 200

Teratoceplialus de Man . . . . . . . . 43

Terniclens Railliet \& Henry . . . . . . . 164

Terranova Leiper \& Atkinson. Vide Porrocaecum . . 6

Terschellingia de Man . . . . . 61,81, 91

Tetracanthus Hemprich \& Ehronberg. Vide Schistorophus 226

Tetracheilonema Diesing . . . . . . 207

Tetradenos v. Linstow. Vide Tanqua . . . . . 233

Tetradonema Cobb. Vide Mermis . . . . 65 
Tetragomphius Baylis \& Daubney

Tetrameres Creplin. Vide Tropisurus

Thalassironus de Man. Vide Ironus

Thalassoalaimus de Man

139,140

Thamugadia Seurat

95

205,206

Thelandros Wedl.

Thelastoma Leidy .

Thelazia Bose

Thelaziidae

Thelazminae

Theristus Bastian. Vide Monhystera

Thominx Dujardin. Vide Capillaria

Thoönchus Cobb

Thoracostoma Marion

Thoracostomopsis Ditlevsen

Thubunaea Seurat

Tipasella Seurat

Tonaudia Travassos

Toxascaris Leiper .

Toxocara Stiles

Trachynema Cobb

Trachypharynx Leiper

Travassosius Khalil

Trefusia de Man

Tribactis Dujardin. Vide Rhabditis

Tricheilonema Diesing

Trichina Owen. Vide Trichinella

Trichinella Railliet

Trichinellid AE

Trichinellinae

Trichinelloidea .

Trichocephalos Goeze. Vide Trichuris

Trichocephalus Schrank. Vide Trichuris

Trichoderma Greeff. Vide Greeffiella

Trichodes v. Linstow. Vide Trichosomoides

Trichodora Cobb. Vide Trichodorus

Trichodorus Cobb.

24

27

224

7,224

224

80

238

116

$134,135,136$

135

223

207

2,3

254

161

180

82

36

207

238

238

237

237

237

238

238

108

239

71

Trichonema Cobbold

Trichonema le Roux (subgen.). Vide Trichonema . . 155

TRICHONEMINAE

154,160

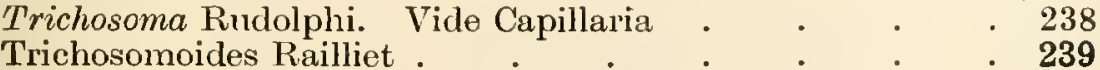

TRICHOSOMOIDINAE

Trichosomum Creplin. Vide Capillaria : : $\quad: \quad .238$

Trichostrongylidae . . . . . . . 179

TRICHOSTRONGYLINAE $. \quad . \quad . \quad . \quad \cdot \quad \cdot \quad . \quad 179$

Trichostrongylus Looss . . • . . • • . 179

TRICHURINAE $\cdot$.

Trichuris Roederer $\quad . \quad$. $\quad$. $\quad$. . . . . . 238

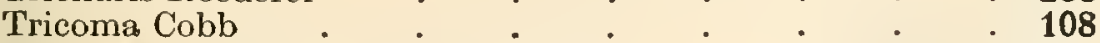

Tricontus Dujardin. Vide Enoplus . . . . 144

Trigonolaimus Ditlevsen $\quad$. . . . . 142

Trilepta Cobb $\quad \cdot \quad \cdot \quad \cdot \quad \cdot \quad \cdot \quad \cdot \quad \cdot 92$

TrILOBIDAE $\quad \cdot \quad \cdot \quad \cdot \quad \cdot \quad \cdot \quad \cdot \quad \cdot 76$ 
Trilobinae. Vide Trilobidae

Trilobus Bastian

Triodontolaimus de Man

Triodontolaimus Micoletzlyy. Vide Parachromadora.

Triodontophorus Looss.

Triodontus Looss. Vide Triodontophorus

Triplonchium Cobb

Triplotriaena Connal. Vide Diplotriaena

Tripula Bastian. Vide Tripyla

Tripyla Bastian

Tripylium Cobb

Tripyloides de Man

Trischistoma Cobb. Vide Tripyla .

Trispieulasearis Skrjabin

Trissonehulus Cobb

Tristichochaeta Paneeri. Vide Chaetosoma

Troglostrongylus Vevers

Tiogolaimus Cobb. Vide Spilophora

Tronidocerca Diesing. Vide Tropisurus

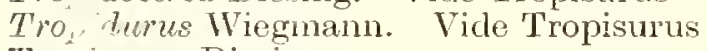

Trcrisurus Diesing

Trymoxymis Vevers. Vide Enterobius

Turida Travassos. Vide Physaloptera

Tycnodora Cobb

Tylelenchus Bastian. Vide Anguillulina.

Tylenchidae. Vide Anguillulinidae

Tylenchinae. Vide Anguillulinidae

Tylencholaimellus Cobb.

Tyleneholaimus de Man

Tylenchomorphus Fuchs. Vide Allantonema

Tylenchorhynchus Cobb. Vide Anguillulina

Tylenchutus Cobb.

Tylylenchus Bastian. Vide Anguillulina .

Tylolaimophorus de Man

Tylopharynx de Man

Typhlophoros v. Linstow

Udonehus Cobb

Uncinaria Frölich .

Uracanthus Diesing

Urolabes Carter .

Vena Gallandat. Vide Dracunculus

Vermiculus Dunglison. Vide Dracunculus

Vetteria Jägerskiöld

Viannaia Travassos

Viannella Travassos

Vibrio Müller

Viguiera Seurat

Viscosia de Man. Vide Oneholaimus

Waleherenia de Man

Warrenius Hall .

Wellcomia Sambon

Wilsonema Cobb (subgen.). Vide Plectus 
Xanthodora Cobb . . . . . . . 138

Xennella Cobb

Xenolaimus Cobb

Xenonema Cobb. Vide Desmodora : . . . 129

Xinema Cobb • • • • ‘. 52

Xiphinema Cobb. Vide Tylencholaimus . . . . 73

Xyala Cobb . . . . . . . 146

Xyo Cobb. Vide Hystrignathus . . . . . 45

Ypsilon Cobb $\quad . \quad$. $\quad . \quad . \quad . \quad$. 134

Yseria Gedoelst. Vide Streptocara . . . . 220

Zalonema Cobb . . . . . . . . . 58

Zanclophorus Baylis \& Daubney . . . . . 18

Zanema Cobb . . . . . . . . 79

Zoniolaimus Cobb. Vide Cloacina . . . . . 163

Zygonemella Cobb $\quad . \quad . \quad . \quad . \quad . \quad . \quad .104$ 
Printed in Great Britain By Richat Clay \& Sons, Linited, BUNGAY, SUFFOLK. 



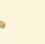

s.

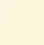



$\therefore a^{3}=$ 
